\title{
nombalina
}

(8)

\section{Luciano I}

\section{Autor(es): $\quad$ Luciano de Samósata}

Publicado por: Imprensa da Universidade de Coimbra; Centro de Estudos Clássicos e Humanísticos

URL persistente:

URI:http://hdl.handle.net/10316.2/9726

DOI:

DOI:http://dx.doi.org/10.14195/978-989-26-0564-7

Accessed : $\quad$ 26-Apr-2023 11:37:15

A navegação consulta e descarregamento dos títulos inseridos nas Bibliotecas Digitais UC Digitalis, UC Pombalina e UC Impactum, pressupõem a aceitação plena e sem reservas dos Termos e Condições de Uso destas Bibliotecas Digitais, disponíveis em https://digitalis.uc.pt/pt-pt/termos.

Conforme exposto nos referidos Termos e Condições de Uso, o descarregamento de títulos de acesso restrito requer uma licença válida de autorização devendo o utilizador aceder ao(s) documento(s) a partir de um endereço de IP da instituição detentora da supramencionada licença.

Ao utilizador é apenas permitido o descarregamento para uso pessoal, pelo que o emprego do(s) título(s) descarregado(s) para outro fim, designadamente comercial, carece de autorização do respetivo autor ou editor da obra.

Na medida em que todas as obras da UC Digitalis se encontram protegidas pelo Código do Direito de Autor e Direitos Conexos e demais legislação aplicável, toda a cópia, parcial ou total, deste documento, nos casos em que é legalmente admitida, deverá conter ou fazer-se acompanhar por este aviso.

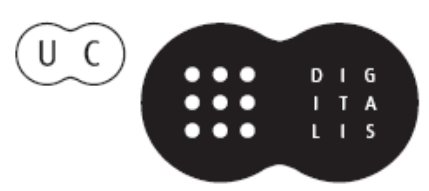


Colecção Autores Gregos e Latinos SérIe TeXTos

\section{LuCiano de Samósata}

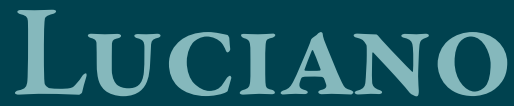

[I]

TRADUÇÃo DO GREGO, INTRODUÇÃO E NOTAS Custódio Magueijo 
Amadurecido pelas viagens e pela experiência da vida, materialmente afortunado, Luciano cedo se farta da actividade judiciária, da retórica e da sofística, para se entregar a uma actividade literária que, não sendo nova, ele, no entanto, reforma de maneira radical: trata-se do diálogo filosófico, mas agora entendido e elaborado segundo princípios originais. De facto, Luciano aligeira substancialmente o majestoso diálogo filosófico que vinha dos tempos de Platão e acrescenta-lhe um aspecto dramático, orientado no sentido da sátira - o que significa reunir no «novo género» dois géneros diferentes e até muito diversos: o diálogo filosófico e a comédia. Realmente, foram sobretudo as obras em forma de diálogo que deram fama a Luciano. É nelas que melhor se expande a sua crítica panfletária e corrosiva, que atinge, literalmente, tudo e todos: os deuses e os heróis, a religião e as religiōes, a filosofia e as suas variadíssimas seitas, a moral convencional, a sociedade e os seus pilares mais destacados, os homens e as suas vaidades, as suas superstiçóes irracionais e o aproveitamento que delas fazem os espertos... enfim, podemos dizer que em Luciano conflui o que de mais violento havia na comédia. Um certo epicurismo prático e um cinismo teórico afinam e refinam o processo. 
(Página deixada propositadamente em branco) 
(Página deixada propositadamente em branco) 


\title{
Luciano de Samósata
}

\section{Luciano}

\author{
[I]
}

Tradução do grego, introdução e notas de Custódio Magueijo

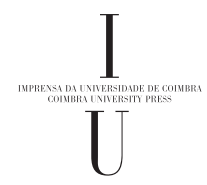


Todos os Volumes desta SÉRIE SÃo SUJeitos A ARBITRAGEM CIENTífica INDEPENDENTE.

Título • Luciano [I]

Traduçấo do Grego, Introdução e Notas • Custódio Magueijo

Autor • Luciano de Samósata

\section{Série Monografias}

Coordenador Científico do plano de ediçấo: Maria do Céu Filho

CoMissão EDTORIAL

José Ribeiro Ferreira

Francisco de Oliveira

Maria de Fátima Silva

Nair Castro Soares

Diretor Técnico: Delfim Leão

\section{Obra REALIZADa no ÂMbito Das actividades Da UI\&D Centro de Estudos Clássicos e Humanísticos}

\section{EdiçÃo}

Imprensa da Universidade de Coimbra

URL: http://www.uc.pt/imprensa_uc

E-mail: imprensauc@ci.uc.pt

Vendas online:

http://livrariadaimprensa.uc.pt

CoORdENAÇÁO EDITORIAL

Imprensa da Universidade de Coimbra

CONCEPÇÃo GRÁFICA

Imprensa da Universidade de Coimbra

INFOGRAFIA

Carlos Costa
Impressáo e ACABAmento

www.artipol.net

ISBN

978-989-26-0543-2

ISBN Digital

978-989-26-0564-7

DOI

http://dx.doi.org/10.14195/978-989-26-0564-7

Depósito Legal

$353356 / 12$

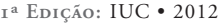

(C) DEZEMBRo 2012.

IMPRENSA DA UNIVERSIDADE DE COIMBRA

Classica Digitalia Vniversitatis Conimbrigensis (http://classicadigitalia.uc.pt)

Centro de Estudos Clássicos e Humanísticos da Universidade de Coimbra

Reservados todos os direitos. Nos termos legais fica expressamente proibida a reproduçáo total ou parcial por qualquer meio, em papel ou em ediçáo electrónica, sem autorizaçáo expressa dos titulares dos direitos. É desde já excepcionada a utilizaçáo em circuitos académicos fechados para apoio a leccionaçáo ou extensáo cultural por via de e-learning. 


\title{
Luciano de Samósata
}

\section{Luciano}

\author{
[I]
}

Tradução do grego, introdução e notas de Custódio Magueijo

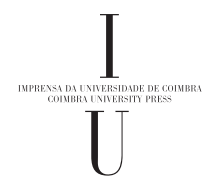


(Página deixada propositadamente em branco) 


\section{SUMÁRIO}

INTRODUÇÃO GERAL

O SONHO OU VIDA DE LUCIANO.

Tradução .

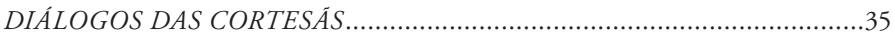

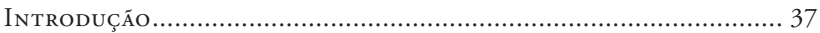

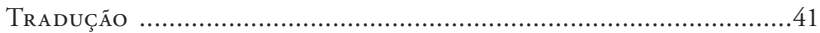

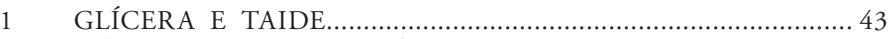

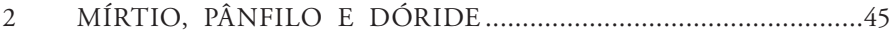

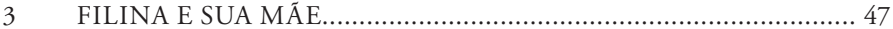

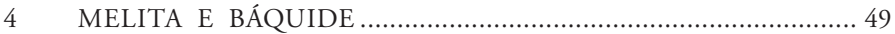

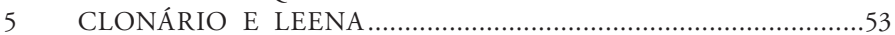

6 CRÓBILA E [SUA FILHA] CORINA ……….............................5

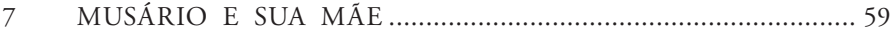

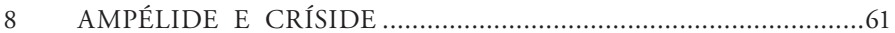

9 DÓRCADE, PANÍQUIDE, FILÓSTRATO E PÓLEMON................ 63

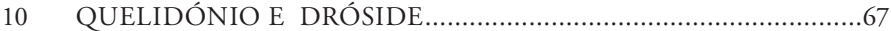

11 TRIFENA E CÁRMIDES ......................................................... 71

12 IOESSA, PÍTIAS E LÍSIAS ………………................................... 73

13 LEÔNTICO, QUÉNIDAS E HÍMNIDE …………………........... 77

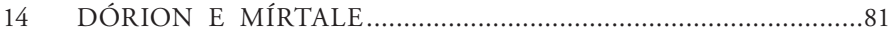

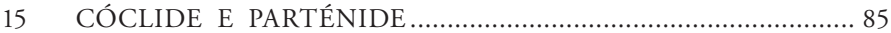

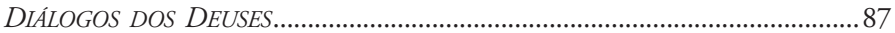

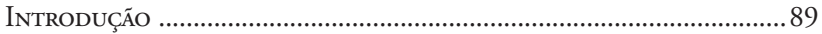

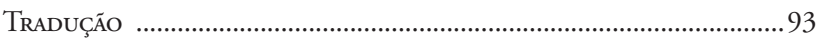

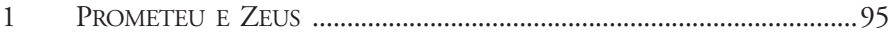

2 EROS E ZEUS ...............................................................................

3 ZEUS E HERMES ……………………………...........................

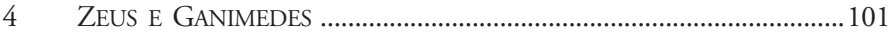

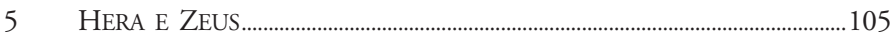

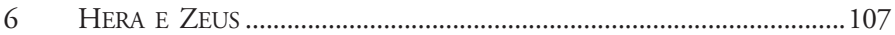

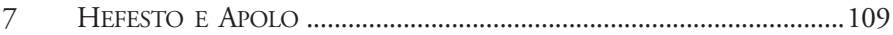

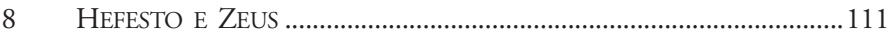

9 POSÍDON E HERMES ……………………………......................... 113 


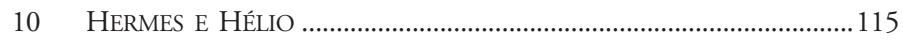

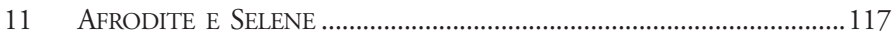

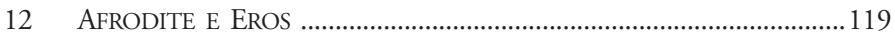

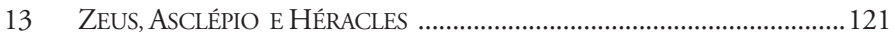

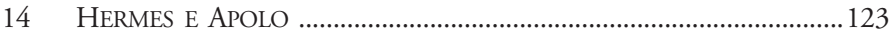

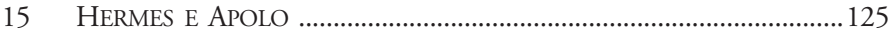

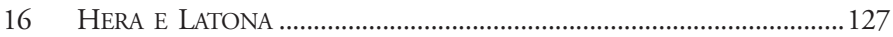

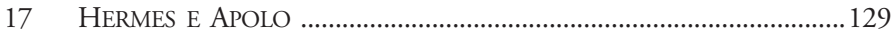

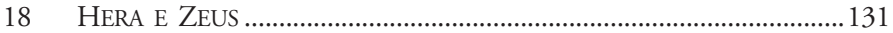

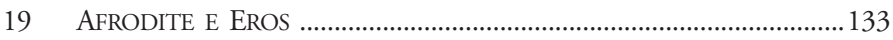

20 Zeus, Hermes, Hera, Atena, Afrodite, PÁris

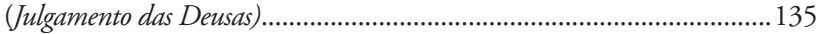

21 ARES E HERMES …………………………….......................... 143

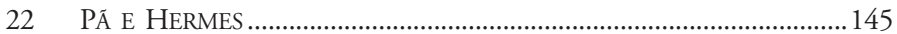

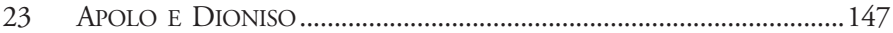

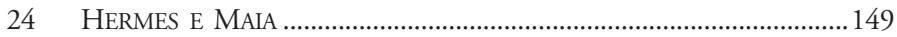

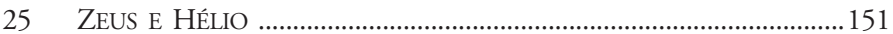

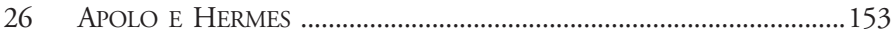

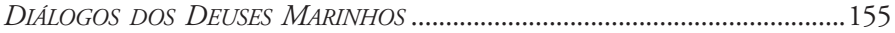

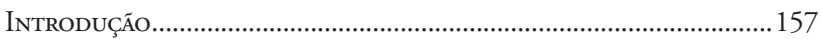

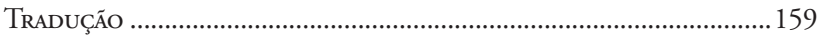

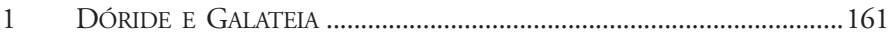

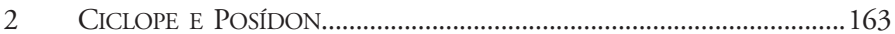

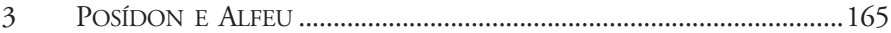

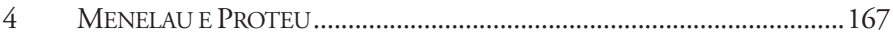

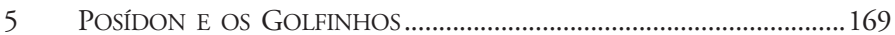

6 POSÍDON, [ANFITRITE] E AS NEREIDAS................................................ 171

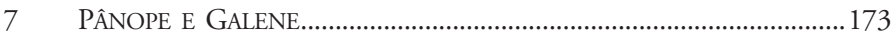

8 TRITÃO, [AMIMONE] E POSÍDON........................................................ 175

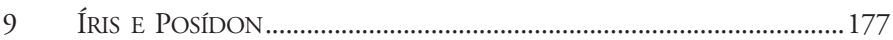

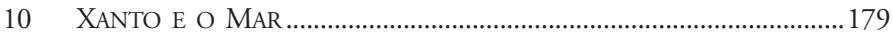

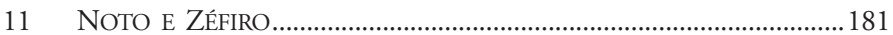

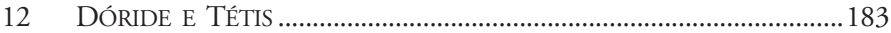

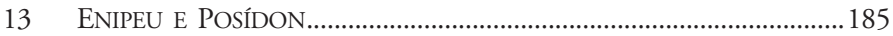

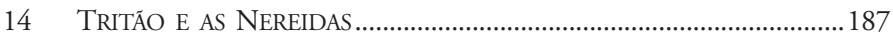

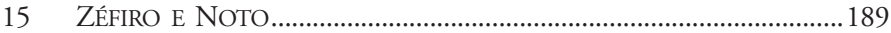




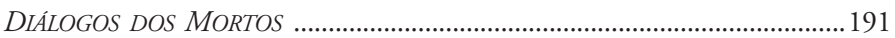

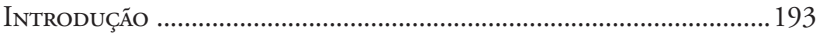

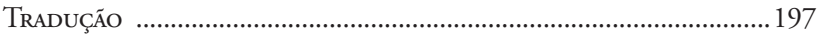

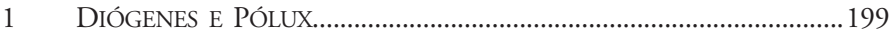

2 Creso, Plutão, MENIPO, MidAS E SARDANAPALO ...............................203

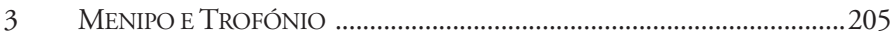

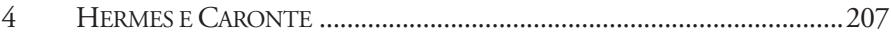

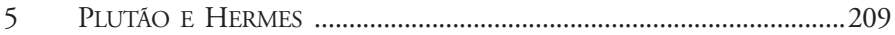

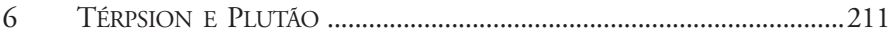

7 ZENOFANTO E CALIDÉMIDES ……………………..........................213

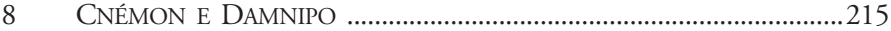

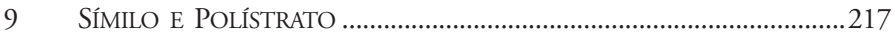

10 CARONTE E HERMES ..................................................................... 221

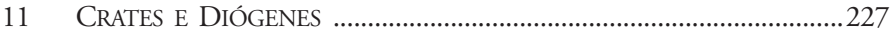

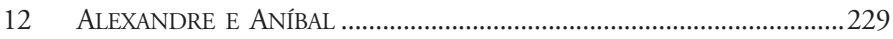

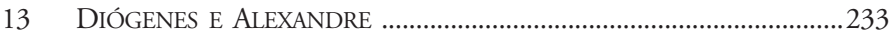

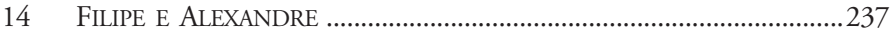

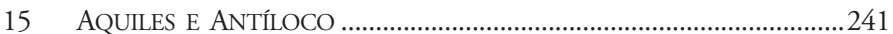

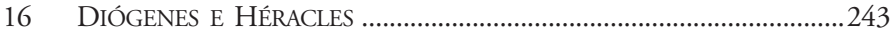

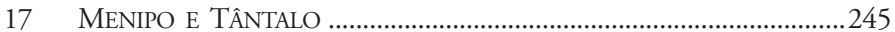

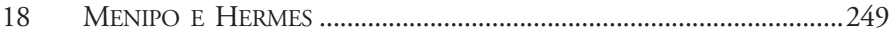

19 ÉACO E PROTESILAU …………………………….............................251

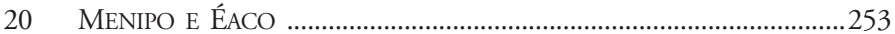

21 MENIPO E CÉRBERO ……………………………….......................25

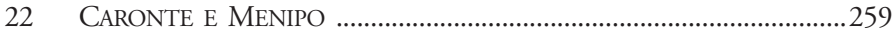

23 PLUTÃO E PROTESILAU ………………………………………........261

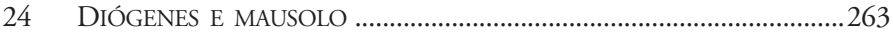

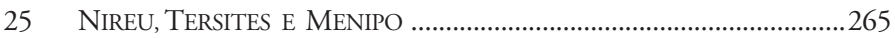

26 MENIPO E QUíRON …………………………….............................267

27 ANTÍSTENES, CRATES E DIÓGENES _...................................................269

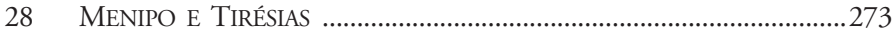

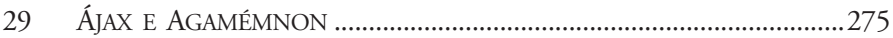

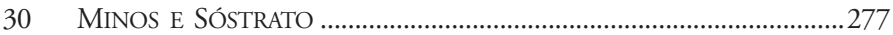

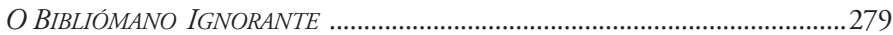

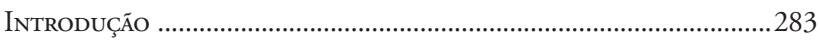

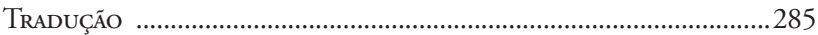

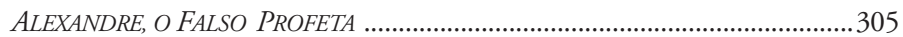

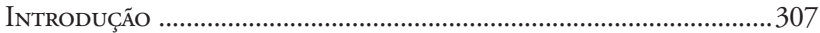

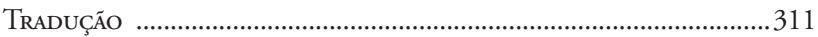

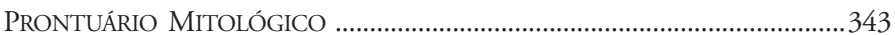




\section{Ficha Técnica}

Autor: Luciano de Samósata

Título: Luciano (I):

- O Sonho, ou Vida de Luciano

- Diálogos das Cortesás

- Diálogos dos Deuses

- Diálogos dos Deuses Marinhos

- Diálogos dos Mortos

- O Bibliómano Ignorante

- Alexandre, o Falso Profeta

Tradução, prefácio e notas: Custódio Magueijo

Edição utilizada: A. M. Harmon, Lucian, The Loeb Classical Library: Greek authors, Harvard University Press, 1959-1961. 


\title{
Luciano
}

\author{
[I]
}

O SONHO OU VIDA DE LUCIANO

DIÁLOGOS DAS CORTESÃS

DIÁLOGOS DOS DEUSES

DIÁLOGOS DOS DEUSES MARINHOS

DIÁLOGOS DOS MORTOS

O BIBLIÓMANO IGNORANTE

ALEXANDRE, O FALSO PROFETA 
(Página deixada propositadamente em branco) 


\section{INTRODUÇÁO GERAL}

Luciano nasceu em Samósata, capital do antigo reino de Comagena, situado a norte da Síria, na margem direita do Eufrates. Os primeiros imperadores romanos conservaram-lhe um certo grau de independência, mas acaba por ser incluído entre as províncias do Império.

Quanto a datas de nascimento e morte, podemos aceitar 125190 d.C. Seguramente, a vida literária de Luciano desenvolve-se na segunda metade do séc. II d.C., por um período de quarenta anos, durante o qual escreveu cerca de oitenta obras ${ }^{2}$.

No tocante a dados biográficos, temos de nos contentar com as informaçóes contidas nos seus escritos: pelo menos têm a vantagem de serem de primeira mão. E se a nossa curiosidade mais «superficial» gostaria de saber muitas outras coisas sobre a sua vida, a verdade é que o essencial do homem está nítida e magnificamente retratado na obra.

De entre as obras mais importantes do ponto de vista autobiográfico, salienta-se a intitulada $O$ Sonho (ou Vida de Luciano). Imediatamente se conclui tratar-se dum trabalho da meia-idade. Após uma peregrinação de vários anos por terras da Grécia, da Itália e da Gália, onde conseguira assinalável êxito e não menos importante pecúlio, Luciano regressa (por volta de 162-163) à sua cidade natal, que o havia visto partir pobre e quase anónimo, e agora se orgulhava do prestígio que lhe era transmitido pelo êxito dum filho seu. É então que Luciano, perante os seus concidadãos, traça uma retrospectiva autobiográfica, de que damos apenas um resumo.

Chegado ao termo da escolaridade elementar, adolescente de quinze anos, o pai aconselha-se com os amigos e familiares sobre o futuro do moço.

${ }^{1}$ Esta "Introdução» é, na generalidade, reproduzida de outras que escrevi a propósito de diversas obras de Luciano. Não se pode exigir que, para cada uma das cerca de oitenta, tivesse de inventar uma biografia formalmente diferente de Luciano. No entanto, a parte final, relativa aos Diálogos das Cortesấs e a outras obras é redigida especialmente para esta edição.

${ }^{2}$ Os críticos modernos tendem a negar a autoria de algumas delas (entre dez e vinte), que seriam imitaçôes de diversas épocas, mas que acabaram por figurar entre as autênticas. 
"A maioria opinou que a carreira das letras requeria muito esforço, longo tempo e uma sorte brilhante. Ora, a nossa fortuna era limitada, pelo que, a breve trecho, precisariamos dalguma ajuda. Se, pelo contrário, eu aprendesse um ofício, começaria imediatamente a retirar dai um ordenado minimo, que me permitiria, naquela idade, deixar de ser um encargo familiar, $e$ até mesmo, algum tempo depois, dar satisfação a meu pai com o dinheiro que traria para casa.» (\$1)

Restava escolher um ofício. Discutidas as várias opiniôes, foi decidido entregar o rapaz aos cuidados dum tio materno, presente na reunião, que era um excelente escultor. Além deste factor de ordem familiar, pesou ainda o facto de o moço, nos seus tempos livres, gostar de se entreter a modelar, em cera, bois, cavalos e figuras humanas, "tudo muito bem parecido, na opinião de meu pai». Por essa actividade "plástica» (é palavra sua), que não raro o desviava dos seus deveres escolares, "chegava mesmo a apanhar pancada dos professores, mas isso agora transformava-se em elogio à minha vocação». (\$2)

Chegado o grande dia, é com certa emoção que o jovem se dirige à oficina do tio. De resto, via no ofício de escultor uma espécie de brincadeira de certo modo agradável, e até uma forma de se distinguir perante os amigos, quando estes o vissem esculpir figuras de deuses e estatuetas. Todavia, e contrariamente às suas esperanças, o começo foi desastroso. $\mathrm{O}$ tio póe-lhe na máo um escopro e manda-o desbastar uma placa de mármore, a fim de adiantar trabalho ("O começar é meio caminho andado»). Uma pancada um pouco mais forte, e eis que se quebra a placa... donde uma monumental sova de correia, que só a fuga consegue interromper. Corre para casa em tal estado, que a mãe náo pode deixar de censurar asperamente a brutalidade do irmão. Entretanto, aproxima-se a noite, e o moço, ainda choroso, dolorido e revoltado, foi deitar-se. As emoçóes do dia tiveram como resultado um sonho — donde o título da obra. (\$\$ 3-4)

Até aqui, Luciano fornece-nos dados objectivos, que nos permitem formar uma ideia suficientemente precisa sobre si próprio e sobre a situação e ambiente familiares. Quanto ao sonho, se nada nos permite duvidar da sua ocorrência, a verdade é que se trata, antes de mais, duma elaboração retórica, elemento tantas vezes utilizado na literatura, mas nem por 
isso menos significativo do ponto de vista autobiográfico. De facto, Luciano serve-se deste processo para revelar aos seus ouvintes náo tanto o que se terá passado nessa remota noite da sua adolescência, mas principalmente a volta que a vida dera, a partir duma situação que, em princípio, teria uma sequência bem diferente.

Assim, e com uma nitidez — segundo afirma — «em nada diferente da realidade», aparecem duas mulheres, que, energicamente e até com grande violência, disputam a posse do moço, que passa duma para a outra, volta à primeira... enfim, "pouco faltou para que me despedaçassem».

Uma delas era a Escultura (Hermoglyphikê), "como (típico) aspecto de operário, viril, de cabeleira sórdida, mãos cheias de calos, manto subido e coberto de pó, como o meu tio quando estava a polir as pedras». A outra era a Cultura (Paideia), "de fisionomia extremamente agradável, atitude mui nobre e manto traçado a preceito". (\$\$ 5-6)

Seguem-se os veementes discursos proferidos por cada uma das personagens, que fazem lembrar o agôn (luta, disputa, certame) das Nuvens de Aristófanes, travado entre a Tese Justa e a Tese Injusta.

A fala da Escultura, mais curta (\$\$ 7-8), contém, no entanto, elementos biográficos (explícitos ou implícitos) de certa importância. Começa por se referir à tradição profissional da família do jovem, cujo avô materno e dois tios, também maternos, eram escultores de mérito. A seguir, enumera as vantagens da profissão: comida farta, ombros fortes e, sobretudo, uma vida particular ao abrigo de invejas e intrigas, em vez de (como, de resto, veio a acontecer - daí também o valor biográfico da informação) viagens por países longínquos, afastado da pátria e dos amigos. Aliás, a História está cheia de exemplos de grandes escultores (Fídias, Míron, Praxíteles), cujo nome é imortal e que são reverenciados juntamente com as estátuas dos deuses por eles criadas.

O discurso da Cultura ( $\$ \$ \$$ 9-13) possui todos os ingredientes necessários à vitória (além das informaçôes biográficas que recolhemos das suas "profecias»... de facto já realizadas). Vejamos alguns passos.

"Meu filho: eu sou a Cultura, entidade que já te é familiar e conhecida, muito embora ainda não me tenhas experimentado plenamente. 
Quanto aos grandes beneficios que te proporcionará o ofício de escultor, já esta aqui os enumerou: não passarás dum operário que mata o corpo com trabalho e nele depóe toda a esperança da sua vida, votado ao anonimato e ganhando um salário magro e vil, de baixo nivel intelectual, socialmente isolado, incapaz de defender os amigos ou de impor respeito aos inimigos, de fazer inveja aos teus concidadãos. Apenas isto: um operário, um dentre a turba, prostrado aos pés dos poderosos, servidor humilde dos bem-falantes, levando uma vida de lebre, presa do mais forte. E mesmo que viesses a ser um outro Fidias ou um Policlito, mesmo que criasses muitas obras-primas, seria apenas a obra de arte aquilo que toda a gente louvaria, e ninguém de bom senso, entre os que a contemplassem, ambicionaria ser como tu. Sim, por muito hábil que sejas, não passarás dum artesão, dum trabalhador manual.

Se, porém, me deres ouvidos, antes de mais, revelar-te-ei as numerosas obras dos antigos, falar-te-ei dos seus feitos admiráveis e dos seus escritos, tornar-te-ei um perito em, por assim dizer, todas as ciências. Equanto ao teu espirito - que é, afinal, o que mais importa -, exorná-lo-ei com as mais variadas e belas virtudes: sabedoria, justiça, piedade, doçura, benevolência, inteligência, fortaleza, o amor do Belo e a paixáo do sublime. Sim, que tais virtudes é que constituem verdadeiramente as incorruptiveis jóias da alma.

Tu, agora pobre, tu, ofilho do Zé-Ninguém, tu, que ainda há pouco havias enveredado por um ofício tão ignóbil, serás, em breve, admirado e invejado por toda a gente, cumulado de honrarias e louvores, ilustre por tua alta formação, estimado das elites de sangue e de dinheiro; usarás um traje como este (e apontava-me para o seu, que era realmente magnífico) e gozarás de merecido prestígio e distinção. E sempre que saias da tua terra, vás para onde fores, não serás, lá fora, um obscuro desconhecido: impor-te-ei tal marca, que, ao ver-te, um qualquer, dando de cotovelo ao vizinho, apontar-te--á com o dedo, dizendo: 'É este, o tal'.

O final do discurso ( $\$ 13)$ constitui um autêntico "fecho» segundo as leis da retórica. Depois de, no parágrafo anterior, ter mencionado os exemplos de Demóstenes (filho dum fabricante de armas), de Ésquines (cuja mãe era tocadora de pandeireta) e de Sócrates (filho de escultor), lança o ataque final:

"Caso desprezes o exemplo de tão ilustres homens, feitos gloriosos e escritos veneráveis, presença imponente, honra, glória e louvores, 
supremacia, poder e dignidades, fama literária e o apreço devido à inteligência, então passarás a usar uma reles túnica encardida, ganharás um aspecto servil, agarrado a alavancas, cinzéis, escopros e goivas, completamente inclinado sobre o trabalho, rastejante e rasteiro, humilde em todas as acepçóes da palavra, sem nunca levantar a cabeça, sem um único pensamento digno dum homem livre, mas antes continuamente preocupado com a ideia de a obra te sair harmoniosa e apresentável - enquanto a respeito de ti próprio, da maneira de te tornares harmonioso e bem dotado, não te importas absolutamente nada; pelo contrário, ficarás mais vil que as próprias pedras."

E pena que esta autobiografia náo tivesse sido escrita uns vinte (ou trinta) anos mais tarde. Em todo o caso, o A., noutras obras, fornece-nos mais algumas informaçóes.

Assim, pela Dupla Acusação (\$27), escrita pouco tempo depois do Sonho, sabemos que Luciano, entregue de alma e coração à retórica e à sofística, iniciara a sua actividade de advogado em várias cidades da Ásia Menor (segundo a Suda, «começou por ser advogado em Antioquia»). Da Ásia Menor passa para a Grécia, e daí para a Itália, mas é sobretudo na Gália que obtém glória e fortuna.

Uma dúzia de anos depois de ter saído da sua terra natal, regressa a casa, mas por pouco tempo. Decide fixar-se em Atenas, onde permanece por cerca de vinte anos (c. 165-185). A Dupla Acusação deve datar dos primeiros anos da sua estada na capital da cultura.

Amadurecido pelas viagens e pela experiência da vida, materialmente afortunado, este homem de cerca de quarenta anos (v. $\$ 32$ ) cedo se farta da actividade judiciária, da retórica e da sofística, para se entregar a uma actividade literária que, não sendo nova, ele, no entanto, reforma de maneira radical: trata-se do diálogo filosófico, mas agora entendido e elaborado segundo princípios originais. De facto, Luciano aligeira substancialmente o majestoso diálogo filosófico que vinha dos tempos de Platáo e acrescenta-lhe um aspecto dramático, orientado no sentido da sátira - o que significa reunir no "novo género" dois géneros diferentes e até muito diversos: o diálogo filosófico e a comédia. Realmente, foram sobretudo as obras em forma de diálogo que deram fama a Luciano. É nelas que melhor se expande a sua crítica 
panfletária e corrosiva, que atinge, literalmente, tudo e todos: os deuses e os heróis, a religião e as religióes, a filosofia e as suas variadíssimas seitas, a moral convencional, a sociedade e os seus pilares mais destacados, os homens e as suas vaidades, as suas superstiçóes irracionais e o aproveitamento que delas fazem os espertos... enfim, podemos dizer que em Luciano conflui o que de mais violento havia na comédia. Um certo epicurismo prático e um cinismo teórico afinam e refinam o processo.

Aos quarenta e poucos anos, adopta uma atitude fundamentalmente céptica, que, sobretudo, se insurge contra todo o dogmatismo metafísico e filosófico em geral. A este respeito, sugere-se a leitura do Hermotimo (ou: As Seitas), obra dum niilismo verdadeiramente perturbador: dada a variedade das correntes filosóficas, e ainda devido ao tempo e esforço necessários a uma séria apreciação de cada uma, o homem, por mais que se esforce, não pode atingir a verdade. Basta citar uma frase, que, não sendo de modo nenhum a mais importante deste diálogo, é verdadeiramente lapidar: "As pessoas que se dedicam à filosofia lutam pela sombra dum burro.» (\$ 86)

Cerca de vinte anos depois de chegar a Atenas, Luciano decide recomeçar a viajar, mas nada será como dantes: já na recta final da existência, talvez em situação financeira menos próspera, e sem dúvida desiludido com o deteriorado clima cultural de Atenas, fixa-se no Egipto, onde aceita (ou consegue?) um lugar de funcionário público, aliás compatível com a sua formação e importância social. Ele próprio nos informa (Apologia dos Assalariados, (\$ 12) de que a sua situação não se compara à dos miseráveis funcionários do Estado Romano (por exemplo: professores), que, afinal, não passam de escravos. E continua:

"A minha condição é completamente diferente. Na vida privada, conservei a minha liberdade; publicamente, exerço uma porçâo da autoridade suprema, que administro em conjunto com o procurador... Tenho sob a minha responsabilidade uma parte considerável da provincia do Egipto, cabe-me instruir os processos, determinar a ordem pela qual devem dar entrada, manter em dia os registos exactos de tudo o que se diz e faz... executar integralmente os decretos do Imperador... E além do mais, o meu vencimento náo se parece nada com o dum simples particular, mas é digno dum rei, e o seu montante, longe de ser módico, ascende a 
uma soma considerável. A tudo isto acrescenta o facto de eu não me alimentar de esperanças modestas, pois é possivel que ainda obtenha, a título pleno, a prefeitura ou qualquer outra função verdadeiramente real.»

Esperanças nada modestas, provavelmente bem fundadas... Só que, por motivos que ignoramos, tudo se desfez em vento.

As «obras completas» de Luciano constam de 82 títulos, embora muitos críticos, com argumentação nem sempre convincente, lhe retirem algumas obras como sendo de imitadores, mas que, em recolhas e cópias posteriores, se teriam agregado às obras genuínas. Em certos casos, parece que têm razão.

De toda a maneira, a glória de Luciano (um dos últimos clássicos) não precisava de que lhe acrescentassem algumas obras, entre as quais, naturalmente, há obras-primas e outras... «não-primas» ou até mesmo... «menos-primas».

De facto, Luciano tem uma visão extremamente crítica da sociedade do seu tempo, dominada pelo irracional, que impregnava não só as grandes massas populares (variadas religiões de mistério e salvação, crendice nas práticas de magia, superstiçóes pueris, etc.), mas até o mundo intelectual, quando este ultrapassava o idealismo estritamente filosófico em que deveria confinar-se. Realmente, muitos desses homens - afamados filósofos e mestres de filosofia - deixaram-se conquistar por uma metafísica que já não era filosófica, mas sim irracionalismo de tipo popular.

Com mais de meio milénio de Filosofia, a Grécia vira nascer, desenvolver-se e evoluir uma grande variedade de correntes de pensamento, que na época de Luciano se tornaram exclusivistas, dogmáticas e intolerantes: pitagóricos, académicos (platónicos), peripatéticos (aristotélicos), cínicos, estóicos, epicuristas, etc., digladiavam-se violentamente. De todas as escolas, Luciano só poupa os epicuristas, precisamente por estes tentarem manter uma atitude racional. O passo $(\$ 32)$ em que Tiquíades se refere a Demócrito (juntamente com Leucipo, o inspirador da vertente científica do epicurismo) é bem significativo da admiraçáo que Luciano tinha por estes homens, apetrechados dum forte espírito crítico, a que Luciano adere.

A este respeito, convirá mencionar, mais uma vez, entre outras obras, o Hermotimo, que é talvez o mais violento libelo 
alguma vez lançado contra todas as correntes idealistas no seu conjunto. Para sermos exactos, Luciano náo condena, propriamente, as diversas escolas filosóficas, mas sim o seu exclusivismo, o seu dogmatismo, a sua intolerância e, muito especialmente, a distância que vai dos princípios morais apregoados à prática real dos grandes mestres.

Se, no que respeita à filosofia, Luciano aceita e compreende as diversas doutrinas em si mesmas e revela admiração pelo epicurismo, já no tocante à religiáo e, sobretudo, à mitologia tradicional, a crítica é global: não nega (pelo menos explicitamente) a existência dos velhos deuses, semideuses e heróis da Grécia. Entende-os, no entanto, e principalmente, como elementos culturais inerentes à organização social e necessários à literatura e às artes. Só não aceita o carácter «literal» de toda uma mitologia fantástica, pueril e, tantas vezes, imoral.

Mas, se a mitologia lhe causa reacções de pura irritação, ainda mais alérgico se revela relativamente às religióes de mistério e salvação, cujos sacerdotes enganam as multidóes por processos grosseiros que uma crítica fria e acerada náo tem dificuldade em desmascarar. Uma das obras mais significativas neste aspecto é a intitulada Alexandre ou o Falso Profeta, que é a biografia vergonhosa dum sacerdote que recorre a truques baixos e ilusionismos ou simples viciação, para se impor como enviado da Divindade.

Um outro aspecto contra o qual se revolta o espírito crítico de Luciano é o do irracionalismo dos grandes filósofos e mestres de filosofia do seu tempo, que acreditam nas artes mágicas, nas curas milagrosas, em fantasmas, espíritos e demónios. É certo que Luciano também escreveu alguns livros de ficção, como, por exemplo, O Burro. Trata-se, porém, de mentiras assumidas, com a finalidade de divertir e distender o espírito (sempre, é claro, com alguma crítica à mistura). Nesta ordem de ideias, aceita, e ele próprio pratica, a fantasia inócua. $\mathrm{O}$ que náo admite é que certas pessoas com responsabilidade na educação da juventude se deixem possuir desse misticismo levado ao mais alto grau do irracional e tentem transmiti-lo aos outros como verdade absoluta e irrefutável.

Tal é o tema do opúsculo $O$ Mentiroso, no qual Tiquíades (que obviamente representa Luciano) relata ao seu amigo Fílocles as histórias incríveis de curas milagrosas, exorcismos, demónios e fantasmas, encantamentos amorosos, apariçóes infernais, 
metamorfoses, levitação, etc., que ouvira contar em casa de Êcrates, onde se havia reunido a fina flor da intelectualidade mais representativa das escolas filosóficas. Só não estava presente um epicurista... a não ser, talvez, Tiquíades: pelo menos é ele o único que tenta contrariar, um por um e com argumentação racional, todo aquele chorrilho de mentiras. Mas a tarefa é difícil, pois, para além de ser um só contra muitos, acontece que é ingrato e incómodo discutir "fenómenos» apresentados como reais, vistos e testemunhados pelos próprios narradores e corroboráveis (mesmo corroborados) por testemunhas «oculares» de confiança... dos narradores. Neste ponto, chamamos a atenção para os processos típicos da "linguagem da verdade», sabiamente utilizados pelos mentirosos de todos os tempos. Ao fim de algum tempo, Tiquíades só vê uma solução: partir a toda a pressa, embora (apesar de tudo...) com uma desculpa de pessoa educada: "Bem, vou-me embora, vou procurar Leôntico, pois tenho necessidade de tratar dum assunto com ele. Quanto a vós, que não julgais já bastantes as coisas humanas, invocai os deuses para que vos ajudem nas vossas histórias prodigiosas.

Além de obras de pura invenção e outras que não passam de exercícios literários em moda, Luciano também escreve a respeito de personagens reais do seu tempo. O Mentiroso, a que acima nos referimos, é uma dessas obras, na qual, muito provavelmente, só os nomes dos intervenientes são fictícios. 
(Página deixada propositadamente em branco) 
O SONHO OU VIDA DE LUCIANO 
Texto da ed. de Karl Mras, Die Hauptwerke des Lukian 


\section{NOTA INTRODUTÓRIA}

Esta obra de Luciano, autobiográfica como é, dispensa, em parte, uma longa introdução. Em todo o caso, remetemos o leitor para a introdução geral e para as introduçóes relativas a cada obra. 
(Página deixada propositadamente em branco) 


\section{O Sonho $O U$ Vida de Luciano}

1. Tinha eu, há pouco, e já adolescente, deixado de frequentar a escola, quando meu pai se aconselhou com os amigos sobre a profissáo que eu devia aprender. Ora, a maioria foi de opiniáo que a carreira das letras requeria muito trabalho, longo tempo, uma despesa nada pequena e uma sorte brilhante, ao passo que os nossos recursos eram exíguos, pelo que, a breve trecho, seria preciso recorrer a um auxílio exterior. Se, porém, eu aprendesse um dos diversos ofícios manuais, em primeiro lugar, retiraria imediatamente do ofício o bastante para a minha subsistência, e deixaria de, já naquela idade, comer à custa da família; e, a mais longo prazo, daria satisfação a meu pai, ao entregar-lhe regularmente algum dinheiro.

2. Posto isto, avançou-se com a matéria do segundo ponto, o de saber qual seria o melhor dos ofícios, o mais fácil de aprender, o mais adequado a um homem livre e aquele que requeresse ferramentas mais fáceis de adquirir e um razoável rendimento. Então, como cada um, de acordo com os seus conhecimentos ou a sua experiência, gabasse este ou aquele ofício, meu pai, olhando para o meu tio (tio materno, presente na reuniáo e considerado um excelente estatuário e um marmorista muitíssimo reputado), disse: "Não parece bem, estando tu aqui presente, dar a preferência a qualquer outro oficio; por isso, leva o rapaz - e apontou para mim -, toma conta dele e ensina-o a tornar-se um bom operário de mármores, um bom polidor e um bom escultor. Sim, ele é, por sua natureza, como sabes, bem capaz disso.» Meu pai deduzia isso das minhas brincadeiras com bonecos de cera. De facto, quando regressava da escola, costumava agarrar em pedaços de cera e moldar bois, cavalos, ou até mesmo, por Zeus!, figuras humanas, tudo muito bem parecido, na opinião de meu pai. Devido a essa actividade, chegava a apanhar pancada dos meus professores, mas agora isso era motivo para louvar o meu talento natural, dando-me boas esperanças de que, a julgar por essa vocaçáo plástica, em pouco tempo aprenderia o ofício.

3. Em breve, pois, chegou o dia de iniciar a minha actividade, confiado aos cuidados de meu tio e, por Zeus!, nada desagradado com o meu trabalho; pelo contrário, parecia-me ver nisso um divertimento nada desagradável, bem como uma demonstração 
de superioridade perante os rapazes da minha idade, ao verem-me esculpir figuras de deuses e fazer pequenas estatuetas, quer para mim próprio, quer para quem eu entendesse. Todavia, logo de início aconteceu-me o que costuma acontecer aos principiantes: de facto, meu tio passou-me para as mãos um escopro e mandou-me desbastar levemente uma placa que para ali estava, dizendo o conhecido provérbio "Começar é meio caminho andado". Eis, porém, que, devido à minha inexperiência, dei uma pancada mais forte, que fez quebrar a placa, pelo que meu tio, muito furioso, agarrou numa correia que estava ali à mão e me «iniciou» no ofício de uma maneira nada meiga e nada apetecível, de tal maneira que foi de lágrimas a minha iniciaçáo no ofício.

4. Finalmente, tendo conseguido escapar-me dali, chego a casa a soluçar continuamente e a chorar, e, com os olhos rasos de lágrimas, conto a cena da correia e mostro as marcas deixadas, queixando-me da grande brutalidade de meu tio e acrescentando que fora por inveja que ele me fizera aquilo, com receio de que eu viesse a ultrapassá-lo no ofício. Minha mãe, também muito irritada, censurou fortemente o irmáo... Enfim, quando chegou a noite, fui deitar-me, ainda lacrimoso, e sonhei durante toda a noite.

5. Até aqui, falei de coisas risíveis e de adolescente. O que, porém, vem a seguir, meus senhores, e que ireis ouvir, é que já não é nada despiciendo, mas antes deve ser escutado por ouvintes atentos. Assim, para citar Homero ${ }^{3}$,

\section{...Um sonho divino me visitou quando dormia, numa noite suave...,}

sonho tão nítido, que em nada se distinguia da realidade. Passado tanto tempo, ainda permanecem nos meus olhos as formas dessas visóes, bem como ressoa ainda nos meus ouvidos o som das palavras que ouvi, a tal ponto foi tudo tão nítido.

6. Duas mulheres pegaram-me pelas mãos e tentavam arrastar-me cada uma para o seu lado, com grande violência e muita força, pelo que, naquela disputa entre elas, pouco faltou para que me despedaçassem. De facto, ora era uma delas que levava a

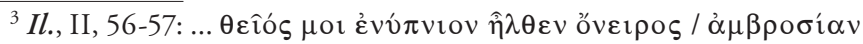
$\delta i \grave{\alpha} v \underline{\kappa} \kappa \alpha \ldots$ 
melhor e por pouco que se apoderava por completo de mim, ora era novamente tomado pela outra. Cada uma delas vociferava contra a outra, pretendendo uma que já tinha tomado posse de mim, pelo que eu lhe pertencia, enquanto a outra argumentava que aquela se arrogava, sem razão, a posse do alheio. Uma delas tinha aspecto de operário, viril, de cabelo desgrenhado, com as mãos cheias de calos, a veste subida até à cintura e toda coberta de pó de mármore, tal e qual o meu tio, quando polia as pedras. A outra, por seu lado, tinha um rosto muito agradável, um porte distinto e um manto muito elegante. Por fim, deixam-me a mim o cuidado de decidir com qual delas eu queria ficar a viver. Falou em primeiro lugar a de aspecto duro e viril, que disse:

7. "Querido menino, eu sou a Escultura, arte que tu ontem começaste a aprender; sou da tua família e do teu parentesco, pois $o$ teu avô (e aqui pronunciou o nome do meu avô materno) era escultor, bem como os teus dois tios, ambos os quais ganharam grande celebridade através de mim. Caso decidas renunciar às lérias e tagarelices desta fulana (e apontava para a outra) e seguir-me a mim e comigo conviver, antes de mais alimentar-te-ás com fartura, possuirás ombros fortes, estarás ao abrigo de toda e qualquer inveja; além disso, nunca viajarás para o estrangeiro, deixando a tua pátria e os teus familiares, nem será pelos teus discursos que todos te louvaráo.

8. Não fiques horrorizado com o meu aspecto vulgar nem com as minhas vestes sujas, pois foi com este aspecto que o famoso Fidias produziu a sua estátua de Zeus, que Policlito fez a sua Hera, que Miron foi louvado e Praxiteles admirado. Por isso, eles sáo venerados juntamente com os deuses [que criaram]. Ora, se tu vieres a ser como um desses artistas, certamente serás considerado ilustre entre todos os homens, tornarás teu pai digno de inveja e tornarás famosa a tua terra natal.» Foram estas, e ainda muitas mais que estas, as palavras da Escultura ${ }^{4}$, cheias de erros e barbarismos ${ }^{5}$, ainda que diligentemente dispostas, no intuito de me persuadir... Mas já não me lembro, pois a maior parte dessas palavras já se me varreu da memória... Então, quando ela terminou, a outra começou mais ou menos assim:

${ }^{4} \mathrm{O}$ texto diz «da Arte»... mas pareceu-me necessário ser mais claro.

5 Note-se que a "versão" de Luciano não contém essas deficiências... mas talvez náo tivesse sido má ideia dar uma amostra do que poderia ser a linguagem de quem não teve instrução avançada. 
9. "Meu filho, eu sou a Cultura, que já te é familiar e conhecida, se bem que ainda não me tenhas experimentado por completo. Ora, quanto aos enormes beneficios que retirarias do oficio de escultor, esta fulana acaba de mencioná-los. De facto, não serás mais que um simples operário, que mata o corpo com trabalho e deposita nele toda a sua esperança de subsistência, ele próprio obscuro, ganhando um salário magro e vil, de mentalidade humilde, desconhecido de toda a gente, nem útil aos amigos, nem temido dos inimigos, nem invejado pelos outros cidadãos, mas apenas isto: um simples operário, um de entre a grande massa popular, sempre ajoelhado aos pés dos notáveis e servidor dos que sabem falar, levando uma vida de lebre e presa dos mais fortes. E mesmo que te tornasses um outro Fidias ou outro Policlito, e produzisses muitas obras admiráveis, seria a [obra de] arte em si aquilo que todos elogiariam, sem que houvesse alguém, entre os que a observavam, que, no seu juizo perfeito, ambicionasse ser igual a ti. De facto, por grande [artista] que sejas, serás visto apenas como um artesão, um trabalhador manual, que vive do trabalho braçal.

10. Se, pelo contrário, me deres ouvidos, antes de mais dar-te-ei a conhecer muitas obras dos homens antigos, explicando-te os seus actos admiráveis e os seus escritos e tornando-te, por assim dizer, perito em todos os ramos do saber... enfim, quanto ao teu espirito, que é a parte mais importante, ornamentá-lo-ei com muitas e belas virtudes, tais como a prudência, a justiça, a piedade, doçura, moderação, inteligência, fortaleza de alma, o amor das coisas belas e $o$ pendor para os assuntos mais sérios. Sim, que é nestas virtudes que reside verdadeiramente a imaculada beleza da alma. Além disso, não só não te escapará nada do saber antigo nem do que deves fazer no presente, mas até, [se ficares] na minha companhia, anteverás o futuro... numa palavra, ensinar-te-ei, num periodo náo muito longo, todas as coisas que existem, quer divinas, quer humanas.

11. Então, tu, agora pobre, tu, o filho de um Zé-Ninguém, que havia deliberado seguir um ofício tão ignóbil, serás, em breve, motivo da inveja e da emulaçáo de toda a gente, honrado, elogiado e apreciado entre as pessoas mais distintas, muito considerado pelas pessoas mais proeminentes de nascença ou de fortuna, vestido com um traje como este (e apontou-me o seu, que era realmente magnífico), e serás digno, enfim, de ocupar um cargo superior ou um lugar de relevo. Para onde quer que viajes, não serás um desconhecido em 
terra estranha nem passarás despercebido, pois imprimir-te-ei uma marca tal, que qualquer pessoa, ao ver-te, dará de cotovelo ao vizinho e te apontará com o dedo, dizendo: 'É este, o tal'.

12. E se algum assunto de magna importância preocupa os teus amigos ou mesmo toda a cidade, todos voltarão para ti os seus olhares; e se por acaso tu tomares a palavra, quase toda a gente, de boca aberta, te escutará, admirando-te e felicitando-te pela força das tuas palavras, bem como ao teu pai, pela ventura [de ter um tal filho]. Mais: aquilo que se diz de certos homens, isto é, que se tornam imortais, é o que eu farei de ti; de facto, quando tu abandonares esta vida, não deixarás de estar presente entre as pessoas cultas nem de conversar com as mais distintas. Vês o célebre Demóstenes, de quem era filho, e o que eu fiz dele? Vês Esquines, que era filho de uma tocadora de pandeireta, e como, devido a mim, Filipe o tratava com tanta consideração? O próprio Sócrates, tendo sido criado no ambiente desta fulana, a Escultura, logo que compreendeu que havia coisa melhor, desertou dela e refugiou-se junto de mim, e agora, como tens ouvido dizer, é celebrado por toda a gente.

13. Ora, caso renuncies a esses homens tão nobres e tão famosos, às suas brilhantes realizaçóes e aos seus veneráveis escritos, ao seu porte distinto, à honra, à fama, aos elogios, à supremacia, ao poder, a altos cargos, ao teu reconhecimento como orador e às felicitaçóes devidas à tua inteligência, então andarás vestido com uma curta túnica encardida, ganharás um aspecto servil, terás nas tuas mãos alavancas, cinzéis, escopros e marretas, inclinado sobre a obra, rastejante e rasteiro, humilde em todo o sentido, sem nunca erguer a cabeça, sem ter qualquer pensamento de homem e de pessoa livre, mas, pelo contrário, somente pensando na maneira de tornar a obra harmoniosa e elegante, ao passo que, no que respeita à maneira de tu próprio te tornares harmonioso e bem dotado, não te preocupas mesmo nada, mas tornas-te ainda mais vil que as próprias pedras.

14. Ainda ela estava a pronunciar estas palavras, eis que eu, sem esperar pelo fim do discurso, levantei-me e fiz a minha escolha: afastei-me da outra, a de aspecto horrendo e de trabalhador, e passei-me para o lado da Cultura, muito contente, tanto mais que me veio ao pensamento a correia e as pancadas, que não foram poucas, que meu tio me dera no dia anterior, logo no começo [do novo trabalho]. Então aquela que tinha sido preterida, ao 
princípio ficou muito zangada, batia com as mãos uma contra a outra $^{6}$ e rangia os dentes, mas, por fim, como se diz de Níobe, ficou hirta e transformou-se em pedra. Não fiqueis incrédulos, meus senhores ${ }^{7}$, com o que aconteceu à Escultura, pois os sonhos são grandes fazedores de milagres.

15. Então a outra, a Cultura, olhou para mim e disse: «Pois vou recompensar-te pelo teu espirito de justiça, por teres julgado tão bem este caso. Vem cá imediatamente, sobe para este carro (e apontou para um carro puxado por cavalos alados parecidos com Pégaso), a fim de conheceres quantas e quão grandes coisas ficarias a ignorar, caso não me seguisses.». Tendo, pois, subido para o carro, a Cultura partiu, dando às rédeas; e eu, elevado aos céus, ia observando, de oriente para ocidente, cidades, naçôes e povos, semeando náo sei bem o quê pela terra, como Triptólemo ${ }^{8}$, mas já náo me lembro que semeadura era essa; só me lembro de uma coisa: que os homens, por onde eu passava durante o voo, elevavam lá de baixo os olhos ao céu, louvavam-me e dirigiam-me palavras de gratidáo.

16. Depois de me mostrar tais maravilhas e de me expor a mim a tais aplausos, trouxe-me de volta, já não vestido com a mesma vestimenta que eu tinha ao levantar voo, mas - assim me pareceu — regressei com magníficas vestes bordadas ${ }^{9}$. Então, foi ao ter com meu pai, que me estava esperando, apontou para aquela veste e para mim, no estado em que eu vinha, e lembrou-lhe a decisáo que, por pouco ${ }^{10}$, eles haviam tomado a meu respeito. Ainda hoje me lembro desse sonho que tive, ao sair da meninice, e que julgo ter-me deixado perturbado devido ao pavor que senti com a pancadaria.

${ }^{6}$ Este gesto de «bater as mãos uma contra outra» pode significar alegria, ou, pelo contrário, desespero, como é o caso; é claro que este gesto devia ser acompanhado de outros, de tipo facial: «ranger de dentes... (v. logo a seguir).

${ }^{7} \mathrm{O}$ texto não diz explicitamente "meus senhores», mas, por um passo anterior, sabemos que Luciano se dirigia a ouvintes: v. $\$ 5$, início.

8 Triptólemo foi o inventor e o divulgador da agricultura.

9 "com magníficas vestes bordadas» é uma versão possível de uma só palavra...

${ }^{10}$ A decisão fora realmente tomada, mas não concretizada definitivamente. 
17. Mas, enquanto eu vos falo, alguém dirá: "Por Héracles!, que sonho tão longo e fastidioso ${ }^{11}$.» $\mathrm{E}$ logo a seguir um outro interrompe: "Deve ser um sonho de Inverno, quando as noites säo muito compridas, ou talvez um sonho de três noites, como no caso de Héracles. Que ideia tola a dele, ao evocar perante nós aquela noite da sua infância, cheia de sonhos velhos e relhos?! Mas que conversa tão sensaborona! Será que ele nos toma por uma espécie de intérpretes de sonhos?» Não meu caro amigo ${ }^{12}$. Na verdade, também outrora Xenofonte, ao narrar um sonho, em que lhe pareceu ver um incêndio na casa paterna $\mathrm{a}^{13}$, e outras circunstâncias que vós bem conheceis, contou tudo isso, não por considerar essa visão uma falsa aparência ou conversa frívola, tanto mais que estavam em guerra, numa situação desesperada e cercados de inimigos, mas porque a narrativa tinha uma intenção algo útil.

18. Pois bem: se também eu vos narrei este sonho, foi por uma razáo: para que os jovens se virem para o bem e se apeguem à cultura, sobretudo no caso de algum desses jovens se deixar levar pela pobreza e caia na depravação, corrompendo assim uma natureza em si mesma nobre. Estou bem convicto de que esse tal jovem se sentirá encorajado ao ouvir a minha história, vendo à sua frente a minha pessoa como um exemplo para si próprio e pensando naquilo que eu era e no êxito que alcancei, por amor da cultura, sem me intimidar com a pobreza desses tempos, e vendo a condiçấo em que aqui cheguei, não mais obscuro, no mínimo $^{14}$, que qualquer escultor.

${ }^{11}$ A palavra grega significa "próprio de advogado», "judiciário»; pressupó-se que tais discursos eram longos e fastidiosos...

${ }^{12}$ Luciano dirige-se explicitamente ao último dos supostos críticos.

13 Sigo a lição de Mras: v. nota ao texto.

${ }^{14}$ Luciano exprime-se pelo mínimo, mas o sentido profundo é que se sentia muito mais famoso do que qualquer escultor. 
(Página deixada propositadamente em branco) 


\section{DIÁLOGOS DAS CORTESÁS}


Texto da ed. de Karl Mras, Die Hauptwerke des Lukian. 


\section{INTRODUÇẤO}

Talvez os mais lidos, comentados e até imitados dos escritos de Luciano sejam os Diálogos: Diálogos dos Mortos, Diálogos dos Deuses, Diálogos dos Deuses Marinhos e Diálogos das Cortesãs. Trata-se de breves quadros dramáticos, em que várias personagens debatem um problema ou uma situação mais ou menos polémica ou censurável, num estilo a que hoje chamaríamos "revisteiro" (até na representação possível), mas nem por isso, no seu conjunto, menos profundo. Nos Diálogos, Luciano critica sobretudo a mitologia tradicional, a ética dos deuses, mas também os comportamentos humanos.

Os Diálogos dos Deuses e os Diálogos dos Deuses Marinhos baseiam-se sobretudo na mitologia e na literatura sua transmissora (Homero, Hesíodo...): Luciano ataca os aspectos mais incríveis e mais irracionais dessas historietas. Os leitores de Luciano recordam particularmente algumas dessas saborosas cenas, como, p. ex., a de Caronte e Menipo (Diálogos dos Mortos, 2): Caronte, o barqueiro dos Infernos, insiste desesperadamente com o filósofo cínico Menipo para que este lhe entregasse o óbolo - pagamento obrigatório, sem o qual os mortos não podem passar para o reino inferior. Ora, sucede que Menipo náo tem com que pagar, pelo que só resta (só restaria!) uma soluçáo: colocar na margem da vida o passageiro mau pagador...

No que diz especialmente respeito aos Diálogos das Cortesäs, trata-se de uma obra importante do ponto de vista da análise social de uma parte da sociedade ateniense do séc. II d.C. Enquanto os outros Diálogos a que atrás nos referimos se inspiram em histórias mitológicas ou na vida de mortos famosos (Sócrates, Filipe, Alexandre, Diógenes, Menipo, etc.), os Diálogos das Cortesãs têm uma forte marca de actualidade, ainda que possamos entrever neles, também, certas personagens da chamada "Comédia Nova»: a cortesã, o jovem apaixonado e ciumento, o criado ou a criada, a máe...

Embora a actividade de prostituta esteja bem documentada na época clássica (a toda a gente ocorre o nome de Aspásia, amante e "companheira» de Péricles), esta profissáo conhece um forte desenvolvimento nos períodos helenístico e romano. Muitas vezes, era o modo mais prático de lutar contra a miséria. Naturalmente, entre as mulheres que viviam do aluguer do corpo, havia as "finas» e as... de esquina de rua ou de encruzilhada, aliás normalmente designadas 
de modo diferente: por um lado, as $\dot{\varepsilon} \tau \alpha \hat{\imath} \rho \alpha \imath$ hetairai, "heteras» ou "cortesãs», que, à maneira das sua predecessoras da época clássica, pretendiam ser "companheiras» dos seus amantes, para o que sabiam proporcionar-lhes outros prazeres além dos da carne: dizia-se que os homens tinham as esposas legítimas para lhes darem filhos, e as heteras para divertimento; por outro lado, a prostituta... de esquina era designada por $\pi$ ó $\rho \vee \eta$ pórnê, «puta» «meretriz», $\pi$ o $\rho v i ́ \delta ı v$ pornidion, "putéfia», às vezes $\pi$ opvíov "putinha»...

À profissão, tendencialmente rendosa, de «cortesã» estava muitas vezes associada a figura da mãe, especialmente da mãe viúva, que punha nos dotes físicos da filha a sua única esperança de não morrer de fome (v. 7: Musário e sua mãe).

Naturalmente, Luciano conhecia o ambiente, não apenas das leituras da Comédia Nova, mas, sobretudo, da vida real ateniense dos meados do séc. II d.C.; e embora a focagem esteja projectada principalmente sobre a cortesã, a mãe, uma amiga, a criada, etc., Luciano náo deixa de nos mostrar alguns exemplares de amantes (homens): os infiéis, os apaixonados, os choróes, os máos-largas e os forretas, os pobretanas, os violentos... Em todo o caso, é importante notar que Luciano não se mostra muito (ou nada!) crítico relativamente à prostituiçáo, que ele devia ver como uma opção de vida por parte da mulher e como uma liberdade por parte do homem. Mais do que criticar, Luciano descreve diversos quadros da vida sexual e do comportamento do jovem e do homem casado do seu tempo. É que, para sermos curtos e breves, certas «instituições», como a escravatura e a prostituição, estavam tão integradas na mentalidade das pessoas, que a ninguém ocorria sequer pô-las em causa.

Um aspecto que, em geral, deixa o leitor moderno um tanto confuso é o que se refere ao valor do dinheiro, já que era este o móbil mais importante (geralmente o único) da profissão. Se não nos é possível ou fácil fazer o "câmbio" para as moedas modernas, podemos, pelo menos, ter uma ideia do seu valor relativo, do poder de compra em relação a um certo número de artigos ou do valor dos serviços prestados. Para o caso, interessa-nos o valor do dinheiro na Atenas de meados do séc. II d.C. Ver quadro:

1 talento $=60$ minas $=6.000 \mathrm{dracmas}=36.000$ óbolos

1 mina $=100 \mathrm{dracmas}=600$ óbolos

$1 \mathrm{dracma}=6$ óbolos 
NOTA - O talento e a mina não eram propriamente moedas, mas aquilo a que se chama "moeda de conto" (cf. um conto de réis $=1$ milhão (1.000.000) de réis).

Vejamos os casos que ocorrem nos Diálogos das Cortesâs:

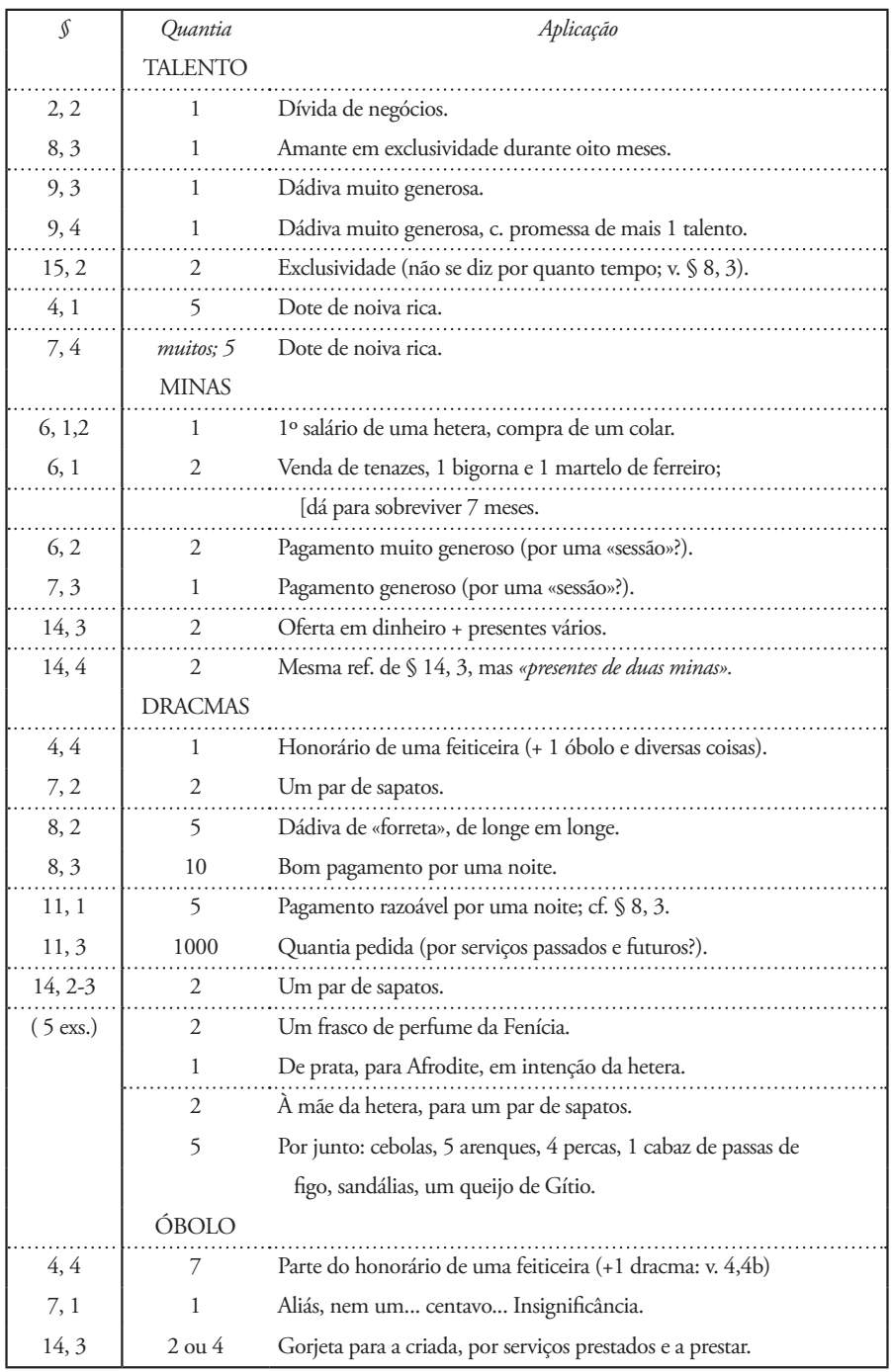


(Página deixada propositadamente em branco) 
DIÁLOGOS DAS CORTESÃS 
(Página deixada propositadamente em branco) 


\section{Glícera e TAIDE ${ }^{15}$}

1] GLíCERA - Ó Taide, conheces aquele soldado acarnano, que em tempos foi amante da Abrótono ${ }^{16}$ e que depois se apaixonou por mim... quer dizer, aquele fulano todo aperaltado, que usava clâmide ${ }^{17}$... Ou será que já te esqueceste do homem?

TAIDE - Não, não, querida Glicério ${ }^{18}$, conheço-o bem, até bebeu connosco o ano passado nas Festas em honra de Deméter. Mas a que propósito vem isso? Sim, parece que querias contar qualquer coisa a respeito desse tipo.

GLÍCERA - Foi o caso que Górgona ${ }^{19}$, essa malvada, que parecia ser tão minha amiga, o seduziu e mo roubou.

${ }^{15}$ Rigorosamente, ao gr. $\Theta \alpha \dddot{\imath} \varsigma$, gen. $\Theta \alpha \dddot{\imath} \delta$ o $\varsigma(-\breve{l}-)$, devia corresponder em português a forma trissilábica, ortograficamente complicada, ${ }^{*}$ Táïde (!), ou, partindo do nominativo, a forma dissilábica, igualmente difícil, *Táïs (!). No primeiro caso, uma forma Taide (que acabei por adoptar) resultaria da sinérese de duas vogais em sílabas diferentes, agora pronunciadas na mesma sílaba: $\boldsymbol{a}-\boldsymbol{i} \boldsymbol{i} \boldsymbol{a} \boldsymbol{i}$ (cf. Danaide, Nereide...); Caso partíssemos do nominativo, já parece menos aceitável adoptar o monossílabo Tais (!), que seria igualmente resultante de sinérese, mas que se me afigura um tanto ridículo, por soar ao pronome tais; também náo seria incontroverso transpor directamente o nominativo grego e verter por Taís, com a acentuação grega, mas que, segundo as regras gráficas do português, obrigaria a uma pronúncia dissilábica; a maior parte das vezes, satisfaz a adaptação a partir do acusativo latino, -em, cf. Acide, Ampélide, Báquide, Cóclide, Corónide, Críside, Dáfnide, Délfide, Dóride (Dóris), Dróside, Éride (Éris), Fébide, Filénide, Grâmide, Hímnide, Nébride, Nereide (e Nereida), Págide, Paníquide, Parténide, Pirálide...; mas o uso também impôs algumas formas a partir do nom.: Tétis...

${ }^{16}$ Abrótono é um nome de mulher (ginecónimo), tirado do nome comum, do género neutro, $\alpha \beta$ pó $\tau$ ovov «abrótono». Em port., não soam bem estes nomes de mulher com a terminação tipicamente masculina, pelo que lhe antepusemos o artigo feminino. Dá vontade de verter por *Abrótona...; o mesmo se diga de diminutivos hipocorísticos em -lov (v. infra, a respeito de Glicério).

${ }^{17}$ A clâmide era uma capa curta, usada sobretudo pelos militares.

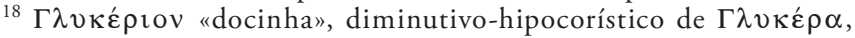
«doce». Como atrás ficou dito, em port. suporta-se mal um ginecónimo em -o, pelo que, aproveitando o valor hipocorístico, antepomos a estes nomes ou querida, ou minha (querida); uma adaptação como ${ }^{*}$ Gliceriazinha não seria de todo reprovável; ou entáo, já que a palavra tem sentido ("doce» e «docinha»), poderíamos verter por Dulce e Dulcinha. Outros diminutivos-hipocorísticos em - lov nesta obra: Mírtio, Clonário, Musário, Quelodónio.

${ }^{19} \mathrm{O}$ nome da "amiga" não é escolhido ao acaso, pois faz-se referência às Górgonas, ou melhor, à mais célebre, Medusa; todas elas eram personagens 
TAIDE - ... E agora o fulano já não vem a tua casa, pois tomou Górgona por sua amante?!

GLÍCERA - Isso mesmo, Taide, e sinto-me muito ferida com este caso.

TAIDE - Sim, querida Glicério, é um acto perverso, mas nada de inesperado; pelo contrário, é prática corrente entre nós, cortesấs. Portanto, não deves afligir-te assim tanto, nem censurar Górgona. Na verdade, anteriormente, a Abrótono também não te censurou pelo mesmo motivo... e, no entanto, vocês eram amigas.

2] Em todo o caso, há uma coisa que me espanta: que é que esse soldado encontrou nela que fosse digno de louvor... a menos que ele fosse completamente cego, a ponto de não ver que ela tem o cabelo ralo e muito afastado da testa ${ }^{20}$; que os lábios são lívidos, o pescoço muito magro e com veias muito salientes e o nariz muito comprido. Só tem de bom o facto de ser alta e esbelta e ter um sorriso muitíssimo sedutor.

GLÍCERA - Cuidas tu, Taide, que o acarnano está apaixonado pela sua formosura? Então não sabes que a feiticeira Crisário ${ }^{21}$ é sua mãe, que conhece certas fórmulas encantatórias tessálicas ${ }^{22} \mathrm{e}$ sabe atrair a lua cá abaixo? Dizem mesmo que ela, à noite, levanta voo. Foi ela que deu a volta à cabeça do fulano, dando-lhe umas drogas a beber; e agora é só "vindimá- $\mathrm{lo}^{23}$ ».

TAIDE - E tu, querida Glicério, hás-de «vindimar» outro e... diz adeus a este.

horrendas, com serpentes à volta da cabeça, dentes compridos...

${ }^{20}$ Como é fácil de perceber pela tradução literal, refere-se a calelo pouco abundante e a grandes «entradas».

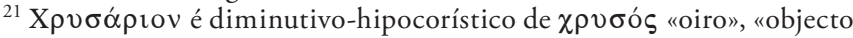
de ouro", «jóia», pelo que o sentido seria, p. ex., "Joiinha».

${ }^{22}$ As feiticeiras tessálicas eram das mais afamadas (e famigeradas) da Grécia. Veja-se, entre outros, Lúcio ou O Burro de Luciano (p. ex., ed. 'Inquérito', trad, de C. M., com o título de Eu Lúcio-Memórias de um Burro).

${ }^{23} \mathrm{O}$ verbo $\tau \rho v \gamma \alpha \dot{\alpha} \omega$ significa "ceifar", "vindimar»e, em sentido figurado, "explorar», o que também é possível em português, embora acrescentando as aspas. 


\section{Mírtio ${ }^{24}$, Pânfilo E Dóride}

1] MíRTiO - Ó Pânfilo, então tu vais-te casar com a filha de Fílon, o armador? Até se diz que já a desposaste. Tantos juramentos que fizeste, tantas lágrimas, será que tudo isso se desvaneceu num instante e esqueceste a tua querida Mírtio, para mais agora, ó Pânfilo, quando estou grávida de oito meses? Portanto, foi isto, e só isto, o que ganhei com o teu amor, o facto de me teres feito uma barriga deste tamanho e de, dentro de pouco tempo, ter de alimentar uma criança, encargo pesadíssimo para uma cortesã. $\mathrm{Na}$ verdade, não tenciono expor o recém-nascido, sobretudo se for macho, caso em que lhe porei o nome de Pânfilo e será a consolação do meu amor; e um dia ele há-de censurar-te por teres sido infiel à sua infeliz mãe. Mas a jovem que tu vais desposar nem sequer é bela, que ainda há pouco tempo a vi na festa das Tesmofórias acompanhada de sua máe, ainda eu não sabia que, por causa dela, nunca mais veria Pânfilo. Portanto, antes [que cases], repara bem nela, no seu rosto e nos seus olhos, para que não te incomode o facto de ela os ter demasiado cinzentos, serem tortos e apontarem um para o outro... Mas certamente já viste Fílon, o pai da noiva, e conheces a sua cara, pelo que já não precisas de ver a filha...

2] PÂNFILO — Ó querida Mírtio, será que tenho de escutar muito mais tempo os teus delírios, ouvir-te falar de raparigas, de casamentos e armadores, se eu conheço alguma noiva de nariz achatado ou formosa, ou, enfim, se Fílon [do demo] de Alópece — julgo que é a esse que te referes - tem uma filha em idade de casar? Ora, esse tal Fílon nem sequer tem relaçóes de amizade com meu pai: de facto, recordo-me de que ainda há pouco tempo meu pai lhe moveu um processo por dívidas, pois o fulano devia um talento ${ }^{25}$, creio, a meu pai e náo queria pagar, pelo que meu pai o levou à presença dos juízes marítimos, onde ele pagou, mas não a quantia total, segundo afirmava meu pai. Ora, se eu estivesse decidido a casar-me, deixaria eu a filha de Démeas, o qual foi general o ano passado, e, para mais, sendo ela minha prima por parte da mãe, para me casar com a filha de Fílon? Mas onde é que

${ }^{24}$ Mais um dim.-hipoc. em - rov.

${ }^{25}$ V. nota especial sobre o valor do dinheiro; o talento não era propriamente uma moeda, mas um valor "de conto"; quando, a seguir, se diz que pagou a dívida de um talento, mas não a quantia total, isso significa que pagou com moedas (minas e dracmas), que não somavam exactamente 1 talento. 
ouviste essa história? Ou será que, por pura fantasia, inventaste, minha querida Mírtio, essa história de ciúmes?

3] MíRTIO-Quer dizer que não te vais casar, Pânfilo?

PÂNFILO - Ó querida Mírtio, estás doida ou ébria? No entanto, ontem náo bebemos em excesso.

MírTIO - Aqui a Dóride é que me desinquietou; de facto, tendo-a eu mandado comprar lá para o parto e orar por mim a Loquia $^{26}$, disse-me que, tendo-se encontrado com Lésbia... Mas... conta-lhe antes tu, Dóride, o que lhe ouviste dizer, se é que não inventaste essa história.

DÓRIDE - Que eu morra já aqui, minha Senhora, se disse alguma mentira. Na verdade, ao chegar ao Pritaneu, encontrei Lésbia, que, toda sorridente, me disse assim: «Então o vosso amante, Pânfilo, vai-se casar com a filha de Fílon»; e, se eu não acreditava, convidou-me a espreitar para a vossa ruela e vê-la toda enfeitada de coroas, bem como tocadoras de flauta, muito alvoroço e pessoas cantando o hino nupcial.

PÂNFILO - E tu foste espreitar, Dóride?

DÓRIDE - Claro, e vi tudo tal como ela me tinha dito.

4] PÂNFILO - Compreendo o engano. De facto, Dóride, nem tudo o que Lésbia te disse era falso, e tu contaste a verdade à nossa Mírtio, mas vós ficastes perturbada sem razão: realmente, o casamento não era em nossa casa; agora me lembro de ter ouvido minha mãe dizer, quando eu ontem regressei de vossa casa: «Ó Pânfilo, Cármides, o filho do nosso vizinho Aristéneto, rapaz da tua idade, vai-se casar já, no que revela ter juizo; e tu até quando farás vida com uma hetera?». Eu, sem ligar ao que ela me dizia, fui-me deitar. Depois, saí de casa logo de manhã, de modo que não vi nada do que Dóride viu a seguir. Se não acreditas, volta lá, Dóride, e repara bem, não na ruela, mas na porta, qual das duas é que está ornada de coroas, e verás que é a dos nossos vizinhos.

MíRTIO — Ó Pânfilo, salvaste-me a vida! Sim, que eu enforcava-me, se isso acontecesse.

PÂNFILO - Mas nunca poderia acontecer: eu não seria tão louco, que esquecesse a minha querida Mírtio, para mais quando me vai dar um filho.

${ }^{26}$ Trata-se de Ártemis, aqui designada pelo epíteto de $\Lambda$ o $\chi \varepsilon i ́ \alpha$, "que preside aos partos». 


\section{Filina e SUA MấE}

1] MÃE - Enlouqueceste, Filina? Que é que se passou ontem no banquete, que logo de manhá veio cá a casa Dífilo, todo lavado em lágrimas, e me contou o mau tratamento que recebeu da tua parte? Disse que tu te tinhas embriagado, que te levantaste e foste dançar no meio da sala, apesar de ele tentar impedir-te, e que, depois de tudo isso, beijaste o seu amigo Lâmprias; depois, como ele, Dífilo, tivesse ficado muito irritado, tu deixaste-o, foste ter com Lâmprias e abraçaste-o; enquanto isto se passava, ele, Dífilo, sufocava de indignação. Nessa noite, ao que parece, não dormiste com ele, mas deixaste-o todo choroso e foste deitar-te sozinha num cama ao lado da dele, cantando e afligindo-o.

2] FilinA - Pois sim, minha mãe, mas o que ele não te contou foi o seu comportamento, pois, nesse caso, já não defenderias esse insolente, que me deixou de lado e foi conversar com Taide, a amante de Lâmprias, o qual ainda não tinha chegado. Entáo ele, ao ver-me irritada e fazendo gestos de cabeça desaprovando o que ele estava a fazer, pegou pela ponta da orelha de Taide, dobrou-lhe o pescoço e beijou-a táo apertadamente, que quase lhe arrancou os lábios. Enquanto eu chorava, ele ria e dizia um longo palavreado ao ouvido de Taide, coisas contra a minha pessoa, certamente, pois Taide olhava para mim e sorria. Então, apercebendo-se da chegada de Lâmprias e já fartos, puseram finalmente termo àquela sessão de beijos mútuos. E eu, apesar de tudo, fui reclinar-se a seu lado, para que ele, mais tarde, não tivesse qualquer pretexto contra mim. Por outro lado, Taide levantou-se e deu início a uma dança, descobrindo as pernas o mais possível, como se fosse a única que tinha pernas belas. Quando ela terminou, Lâmprias ficou quieto, sem dizer nada, mas Dífilo elogiou longamente a harmonia do ritmo e a coreografia, a forma como o movimento dos pés e das pernas condiziam com o toque da cítara, e mil outros elogios, como se estivesse a elogiar a [estátua de] Sosandra de Calâmide, e não Taide, cujo físico tu bem conheces, por vê-la no balneário connosco. Então, essa mesma Taide deu em fazer troça de mim: «Se há por ai alguém - disse - que não se envergonhe de ter umas pernas muito delgadas, que se levante e dance." Que dizer disto, minha mãe? Levantei-me e dancei. Sim, que outra coisa 
poderia eu fazer? Aguentar, dando assim razão à crítica e deixar que Taide fosse a rainha da festa?

3] MÃE - É realmente um caso de honra, minha filha, mas náo devias dar-lhe tanta importância. Mas conta lá o que se passou a seguir.

FILINA - Todos os convivas aplaudiam, menos Dífilo, que, tendo-se reclinado de costas, esteve sempre a fitar o tecto, até eu parar extenuada.

MÃE - Mas é verdade que beijaste Lâmprias e que saíste do teu lugar para ir abraçá-lo?... Porque ficas calada? Sim, que isso é que já não merece perdão.

FILINA - O que eu queria era retribuir-lhe a ofensa.

MÃE - E depois nem sequer dormiste com ele, mas puseste-te a cantar, enquanto ele chorava?! Ó minha filha, não vês que somos pobres? Não te lembras dos muitos presentes que recebemos dele nem como teríamos passado o último Inverno, se Afrodite não no-lo tivesse enviado? 


\section{Melita ${ }^{27}$ E BáQUide}

1] MELITA — Ó Báquide, se conheces alguma velha, de entre tantas [bruxas] tessálicas, que se diz haver por aí, daquelas que usam fórmulas mágicas que tornam as pessoas apetecíveis, mesmo que se trate de uma mulher extremamente abominável, pela tua saúde, pega nela e trá-la cá. Eu daria de bom grado os meus vestidos e todas estas jóias, se visse Carino voltar de novo para mim e odiar Símica como agora me odeia a mim.

BÁQUIDE - Que estás a dizer? Já não viveis juntos, mas Carino foi viver com Símica, deixando-te a ti, Melita, por causa de quem afrontou a cólera dos pais, por não querer casar com aquela ricaça, que, segundo dizem, trazia um dote de cinco ta$\operatorname{lentos}^{28}$ ? Sei disso por te ter ouvido falar do caso.

MELITA — Foi-se tudo, Báquide; há já cinco dias inteiros que não o vejo, pois ele e Símica vão fazer festança em casa do seu companheiro Pâmenes.

2] BÁQUIDE - Que coisa terrível te aconteceu, Melita. Mas que é que foi que vos separou? Realmente, não parece ter sido coisa pequena.

MELITA - Não posso contar todo o caso em pormenor; mas, aqui há dias, tendo Carino regressado do Pireu (aonde seu pai o tinha enviado, a fim de - julgo eu - cobrar uma dívida), ao entrar em casa, nem olhou para mim nem me correspondeu quando eu, como era meu hábito, corri para ele, mas, pelo contrário, rechaçou-me quando eu pretendia abraçá-lo, dizendo: «Vai-te já daqui, vai ter com o armador ${ }^{29}$ Hermotimo ou vai ler o que está escrito nos muros do Ceramico, onde os vossos nomes estão gravados numa coluna." Ao que eu respondi: "Qual Hermotimo, qual? Ou a que coluna te referes?». Ele, porém, não respondeu e, sem ter ceado, foi-se deitar, de costas viradas para mim. Podes imaginar de quantas truques eu usei: abracei-o, tentei virá-lo para o meu

${ }^{27}$ Mé $\lambda \imath \tau \tau \alpha$ «abelha» (com - $\tau \tau-$ ) é forma tipicamente ática; em jónico (na koinê e em gr. mod.) a forma normal é $\mu \varepsilon \dot{\varepsilon} \imath \sigma \sigma \alpha$ (com - $\sigma \sigma-$ ); se nos baseássemos nesta última forma, teríamos Melissa (que, afinal, existe...).

${ }^{28} \mathrm{O}$ talento era aquilo a que se chama "moeda de conto" (cf. contos de réis), ou seja, não existia como moeda. Equivalências: 1 talento $=60$ minas; $1 \mathrm{mina}=100$ dracmas; $1 \mathrm{dracma}=6$ óbolos. No caso presente, $\mathrm{a}$ noiva trouxe como dote 5 talentos. É só fazer a conta...

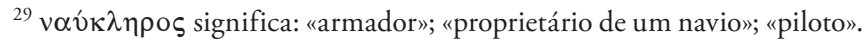


lado, beijei-lhe as omoplatas, e ele sempre de costas para mim, até que, sem dar quaisquer mostras de ceder, disse: «Se continuas a incomodar-me, vou-me já daqui embora, mesmo sendo meia-noite».

3] BÁQUIDE - Mas, afinal, tu conhecias esse tal Hermotimo?

MELITA - Ó Báquide, assim tu me visses numa situação mais infeliz do que aquela em que agora estou, se eu conheço algum armador de nome Hermotimo. Ora, no dia seguinte, logo de manhá, ao cantar do galo, Carino acordou e saiu de casa; eu, lembrando-me de que ele havia dito que o meu nome estava escrito num certo muro do Ceramico ${ }^{30}$, mandei Ácide examinar a coisa; ela não encontrou nada, a não ser esta frase gravada num muro próximo do Dípilo, à direita de quem entra: "Melita ama Hermotimo»; e novamente, um pouco mais abaixo: "O armador Hermotimo ama Melita».

BÁQUIDE - Mas que intrometidos que são os jovens! Sim, estou a entender: algum deles, querendo afligir Carino, e sabendo como ele é ciumento, escreveu a frase; e ele acreditou. Mas deixa estar que, se eu o encontrar por aí, falarei com ele, que é muito inexperiente e ainda muito novo.

MELITA — Onde é que o encontrarás, se ele se encerrou e está sempre com Símica? Os pais dele ainda o procuram em minha casa... Mas, oxalá, Báquide, achemos alguma velha como eu te disse, que apareça para me salvar.

4] BÁQUIDE — Sim, minha querida amiga, há aí uma excelente feiticeira, síria de nascimento, muito dura e implacável, que, uma vez, estando Fânias zangado comigo sem razão, tal como agora Carino, o reconciliou comigo, passados quatro meses inteiros; quando eu já desesperava, Carino voltou de novo para mim, arrastado pelas fórmulas encantatórias.

MELITA - E quanto é que a velha cobra, se é que ainda te recordas?

BÁQUIDE - Nem cobra honorários muito elevados, Melita: apenas uma dracma e um pão; a isto há que acrescentar, além do sal, sete óbolos, enxofre e um archote. A velha fica com tudo isto; também é preciso encher uma cratera de vinho aguado ${ }^{31}$, que a

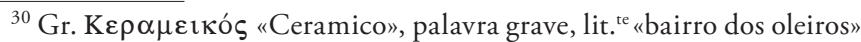

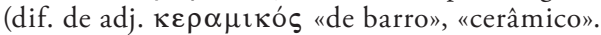

${ }^{31}$ Os gregos bebiam o vinho misturado com água, numa proporção que variava; naturalmente, os grandes bebedores bebiam-no puro: Adde 
velha bebe sozinha. Finalmente, será necessário algum objecto pertencente ao homem, como mantos, sapatos, um pouco de cabelo, ou qualquer coisa do género.

MELITA - Tenho sapatos seus.

5] BÁQUIDE - Então ela pendura-os num prego, queima enxofre por debaixo e espalha sal sobre o lume, proferindo os nomes de ambos, de Carino e o teu. Depois, tirando do seio um fuso mágico, fá-lo girar, ao mesmo tempo que, com um palavreado muito enrolado, recita uma fórmula encantatória composta de palavras bárbaras e que causam calafrios. Isto foi o que ela fez naquela ocasião; e de facto, passado pouco tempo, Fânias, apesar de os seus companheiros o censurarem e de Fébide, com quem vivia, lhe suplicar, veio para a minha companhia, arrastado sobretudo pela fórmula mágica. Além disso, a feiticeira ensinou-me este processo de causar um forte ódio [de Fânias] contra Fébide: observar a marca dos passos deixados por ela e apagá-los, colocando o meu pé direito sobre a marca do pé esquerdo dela, depois o meu pá esquerdo sobre a marca do pé direito, e dizer: "Andei em cima de ti e estou por cima de ti.» E fiz tudo o que a feiticeira me ordenou.

MELITA - Rápido, rápido, Báquide, vai chamar essa síria. E tu, Ácide, prepara o pão, o enxofre e tudo o mais que é necessário para a fórmula encantatória.

merum «chega-lhe do puro!», diz um verso de Horácio. 
(Página deixada propositadamente em branco) 


\section{Clonário e Leena ${ }^{32}$}

1] CLONÁRIO - Ó Leena, que coisa bizarra temos ouvido dizer a teu respeito: que a ricaça Megila de Lesbos te ama à maneira de homem e vós viveis juntas, fazendo não sei o quê uma com a outra. O quê? Ficaste corada? Diz lá se isso é ou não verdade.

LEENA - É verdade, querida Clonário, e eu estou envergonhada, pois é uma coisa antinatural.

ClONÁRIO - Por Afrodite ${ }^{33}$, que coisa essa! Mas que é que quer essa mulher? Que é que vós fazeis quando estais juntas? Estás a ver? Tu não me amas, senão não me ocultavas o facto.

LEENA - Amo, pois, mais que a qualquer outra, mas essa mulher é terrivelmente varonil.

2] ClONÁRIO - Não percebo o que queres dizer, a não ser, porventura, que se trate de uma espécie de amásia de mulheres, às quais, em Lesbos, chamam «mulheres-machos», que não querem suportar o jugo de homens, mas que têm relaçóes com mulheres, fazendo elas próprias de homem.

LEENA - É mais ou menos isso.

CLONÁRIO - Pois bem, Leena, conta-me lá tudo isso: como é que, de início, ela te tentou, como é que tu te deixaste persuadir, e o que veio a seguir.

LEENA - Tendo ela organizado uma festa, ela e a coríntia Demonassa, mulher igualmente rica e dada às mesmas práticas que Megila, esta levou-me também a mim, a fim de tocar cítara para elas. Quando acabei de tocar, era já muito tarde, precisávamos de dormir, e elas estavam embriagadas. "Ó Leena — disse Megila - é melhor irmos já deitar-nos; dorme aqui connosco, no meio das duas.»

CLONÁRIO - E tu dormiste? E depois que é que aconteceu?

3] LEENA - Primeiro, começaram por me beijar como fazem os homens, náo só aplicando os seus lábios nos meus, mas escancarando a boca, ao mesmo tempo que me abraçavam e me apalpavam

${ }^{32}$ Como subst. comum, $\kappa \lambda \omega v \alpha$ ó $\Lambda \varepsilon ́ \alpha \iota v \alpha$ (Léaina) significa "leoa». As regras da adaptação em português nem sempre soam muito bem, como é o caso, nomeadamente de ginecónimos hipocorísticos em - lov, que resultam em nomes femininos (?) em -o: Clonário, Glicério, Musário, Quelidónio, etc.

${ }^{33} \mathrm{O}$ texto diz "pela educadora de jovens», um dos epítetos de Afrodite. 
os peitos. Demonassa mordia-me ao beijar-me. Eu não sabia o que pensar daquilo tudo. Passado algum tempo, Megila, que já estava um tanto excitada, tirou a peruca, que lhe assentava muito bem e parecia natural, mostrando-se completamente rapada, como os atletas mais viris. Eu, ao vê-la assim, fiquei perturbada. Então diz-me ela: "Ó Leena, já alguma vez viste um jovenzinho tão belo?». E eu: "Mas, ó Megila, não vejo aqui nenhum jovenzinho...». "Não me trates no feminino — disse ela —, o meu nome é Megilo; desposei há muito tempo aqui a Demonassa, que agora é minha esposa." Ao ouvir tal, ó querida Clonário, dei uma gargalhada e disse: "Quer dizer, ó Megilo, que tu andavas a esconder de nós o facto de seres homem (tal como Aquiles, que, segundo se diz, se escondia entre as moças) e que tens aquela coisa viril e fazes com a Demonassa o mesmo que os homens fazem?" E ela responde: "Ó Leena, aquela coisa... não tenho, mas também não preciso absolutamente nada dela; verás, quando eu estiver a 'trabalhar', que eu tenho um método muito próprio e muito mais gostoso." "Não serás tu — disse eu - um hermafrodita, um dos muitos que, segundo se diz, têm ambos os sexos?" Na verdade, amiga Clonário, eu desconhecia completamente a coisa. «Nada disso — respondeu Megila — sou verdadeiramente homem.»

4] E eu disse: "É que ouvi a beócia Ismenodora, tocadora de flauta, contar, entre as histórias da terra dela, que existiu em Tebas uma mulher que se transformou em homem, e que este era um excelente adivinho, creio que chamado Tirésias. Não se terá passado o mesmo contigo?" "Nada disso, Leena — disse ela —, eu nasci igual às outras mulheres, só os meus pensamentos e os meus desejos e todos os outros sentimentos são próprios de homem." "Mas — disse eu - será que os desejos bastam?" Ao que Megila respondeu: "Se duvidas, Leena, acede aos meus desejos e verificarás que não fico a dever nada a um homem, pois possuo uma certa coisa que substitui o órgáo viril; mas acede e verás.» $\mathrm{E}$ eu, amiga Clonário, acedi, não só por ela me suplicar insistentemente, mas também por me oferecer um colar dos mais valiosos e vestidos dos mais finos. Depois, abracei-a como se faz a um homem, enquanto ela 'trabalhava', beijando-me e arfando, pelo que me pareceu que estava a gozar à grande.

ClONÁRIO - Mas afinal, Leena, que é que ela fazia? Como é que fazia? Diz-me sobretudo isso.

LEENA - Não queiras saber pormenores, pois são indecorosos, de tal modo que, por Afrodite Celeste, nunca os revelaria. 


\section{Cróbila e [SUa filha] Corina}

1] CRÓBILA - Agora já sabes, Corina, que não é tão mau como tu julgavas passar de rapariga a mulher, viver com um jovem formoso e ganhar como primeiro salário uma mina, com a qual vou já comprar-te um colar.

CORINA - Sim, mamázinha, um que tenha umas pedrinhas cor de fogo, como o de Filénide.

CRÓBILA - Assim será. Mas escuta outra coisa que tenho para te dizer: o que deves fazer e como deves comportar-te com os homens. $\mathrm{Na}$ verdade, minha filha, não temos outro meio de vida; não sabes como temos sobrevivido, desde há dois anos que o teu pai, de boa memória, morreu? Enquanto ele foi vivo, tínhamos tudo com fartura, pois era ferreiro no Pireu, onde desfrutava de enorme prestígio; ainda hoje, podemos ouvir toda a gente jurar que, depois de Filino, não haverá nunca outro ferreiro como ele. Após a sua morte, comecei por vender as tenazes, a bigorna e o martelo, tudo por duas minas, com as quais nos sustentámos durante sete meses. Depois, umas vezes tecendo, outras movendo a naveta ou fazendo girar o fuso [v. bem todo o periodo], lá ia ganhando a vida a muito custo. Criei-te a ti, minha filha, como minha única esperança.

2] CORINA - Estás a referir-te à mina [que eu ganhei]?

CRÓBILA - Nada disso, mas pensava que tu, ao chegares à idade que tens agora, tomarias conta de mim e, ao mesmo tempo, facilmente terias jóias, enriquecerias e terias vestidos de púrpura e criadas.

CORINA - Mas como, minha mãe? Que queres tu dizer com isso?

CRÓBILA - Juntando-te com jovens, bebendo com eles e com eles dormindo a troco de dinheiro.

CORINA - Tal como Lira, a filha de Dáfnide?

CRÓBILA - Isso mesmo.

CORINA - Mas essa é uma cortesã.

CRÓBILA - E que mal tem isso? Sim, também tu enriquecerás, tal como ela, e terás muitos amantes. Mas... porque estás a chorar, Corina? Não vês como são tantas e tão procuradas as cortesãs e quanto dinheiro ganham? Conheço muito bem 
a filha de Dáfnide (que Adrastia ${ }^{34}$ me perdoe!): andava toda esfarrapada, antes de a filha crescer e se tornar uma moça vistosa. Mas agora vê lá como ela prosperou: ouro, vestes garridas e quatro criadas.

3] CORINA - Mas como é que Lira conseguiu tudo isso?

CRÓBILA - Antes de mais, vestindo-se com elegância e mostrando-se simples e bem disposta com todos os homens, sem ir ao ponto de soltar gargalhadas, como tu costumas fazer, mas sorrindo docemente e de maneira sedutora; depois, tratando-os com muito tacto e não iludindo quem vem procurá-la ou lhe faz a corte, mas também sem se apegar a nenhum homem. E sempre que vai a um jantar mediante salário, não se embriaga (coisa ridícula; os homens detestam tais mulheres) nem se atafulha alarvemente de comida, mas toca-lhe só com a ponta dos dedos, [come] cada porção em silêncio, sem atafulhar ambas as bochechas, bebe tranquilamente, não de enfiada, mas em pequenos tragos.

CORINA - Mesmo que esteja com muita sede, minha mãe?

CRÓBILA - Sobretudo se tem muita sede. Além disso, não fala mais do que o necessário nem troça de nenhum dos convivas, e só olha para aquele que lhe paga. É por isso que os homens gostam dela. Quando é preciso ir para a cama, não procede nem com insolência nem com frieza, mas procura, acima de tudo, atrair o homem e fazê-lo apaixonar-se por si. É isto o que todos os homens louvam nela. Se tu, minha filha, aprenderes estas regras, também nós seremos felizes, tanto mais que os teus dotes [físicos] são muito superiores aos dela... e não digo mais... que Adrastia ${ }^{35}$ me perdoe... só te desejo longa vida.

4] CORINA - Diz-me, mãe: todos os pagantes são como Eucrito, com quem dormi a noite passada?

CRÓBILA — Nem todos: uns são mais belos, outros mais viris, outros não devem lá muito à formosura.

CORINA - E terei de dormir também com esses?

CRÓBILA - Sobretudo com esses, minha filha. Esses são os que pagam melhor. Os homens belos só querem uma coisa: serem

${ }^{34}$ 'A $\delta \rho \alpha \sigma \tau \varepsilon \imath \alpha$ é um outro nome de Némesis, a deusa que, entre outras coisas, punia as pessoas demasiado felizes, especialmente se se envaideciam com isso. Aqui, Cróbila, ao fazer referência ao próspero estado actual da filha de Dáfnide e de sua mãe, invoca a deusa, para que esta não as castigue.

${ }^{35} \mathrm{~V}$. nota supra. 
belos. Mas tu preocupa-te sempre com o lucro, se queres que, dentro de pouco tempo, todas as mulheres te apontem a dedo e digam: "Não vês a Corina, a filha de Cróbila, não vês como está tão rica e como fez sua mãe três vezes feliz?» Que dizes? Vais proceder deste modo? Pois vais, que eu bem sei, e não terás dificuldade em ultrapassar todas as outras. Agora, vai tomar um banho, para o caso de o jovem Êcrito vir cá hoje, pois assim prometeu. 
(Página deixada propositadamente em branco) 


\section{Musário e sua Mấe}

1] MÃE - Ó querida Musário, se encontrarmos um outro amante da qualidade de Quéreas, devemos sacrificar uma cabra branca a [Afrodite] Pandemo, uma vitela à [Afrodite] Celeste que está nos jardins e oferecer uma coroa à [Deméter] dispensadora de riqueza, pois seremos felizes, três vezes felizes. Estás a ver quanto é que temos recebido desse jovem, que nunca te deu nem sequer um óbolo, nem um vestido, nem uns sapatos, nem um [frasco de] perfume... só desculpas, promessas, longas esperanças e sempre a frase: "Se meu pai... se eu fosse senhor dos bens paternos, seria tudo teu.» E tu afirmas que ele fez juramento de que faria de ti a sua legítima esposa.

MUSÁRIO - Sim, minha mãe, jurou pelas duas deusas ${ }^{36} \mathrm{e}$ por Atena Políade.

MÁE - E tu acreditas, é claro. Foi por isso que outro dia, como ele não tivesse com que pagar a sua quota-parte [no banquete], tu, sem eu saber, lhe deste um anel, que ele vendeu para ir beber, e também os dois colares jónicos, que pesavam dois daricos cada um, que o armador Práxias de Quios mandou fazer em Éfeso e te trouxe. Sim, que Quéreas devia entrar com a sua parte juntamente com os amigos. E a respeito de vestidos e túnicas, que é que eu posso dizer? Enfim, calhou-nos em sorte um sujeito que tem sido para nós uma mina e fonte de rendimento!

2] MUSÁRIO - Mas é formoso e ainda imberbe, e afirma que me ama, e chora, e, além disso, é filho de Dinómaca e do areopagita Laquete, e diz que vai casar comigo, e dá-nos as mais firmes esperanças... basta que o velho feche os olhos.

MÃE - Pois bem, querida Musário, se precisarmos de um par de sapatos e o sapateiro nos pedir duas dracmas, dir-lhe-emos: "Não temos dinheiro, mas aceita umas quantas esperanças." E diremos o mesmo ao padeiro; e, quando nos exigirem a renda da casa, diremos: "Espera até que Laquete de Colito morra, que te pagarei logo a seguir ao casamento." Não te envergonhas de ser a única das cortesás que não tem uns brincos, um colar, um vestido tarentino?

${ }^{36}$ Deméter e Prosérpina. 
3] MUSÁRIO - E daí, minha mãe, são elas mais felizes e mais belas que eu?

MÃE - Não, mas são mais espertas e sabem ser cortesãs; não acreditam em palavrinhas doces nem em rapazotes que têm sempre juramentos na ponta dos lábios, ao passo que tu és fiel e apegada a um só homem, não deixas aproximar-se de ti mais nenhum que não seja Quéreas. Ainda outro dia, quando aquele lavrador acarnano (e esse também era ainda imberbe) cá veio oferecer-te duas minas, que tinha tirado do dinheiro do vinho que seu pai o mandara vender, tu desdenhaste dele, para ir dormir com o teu Adónis-Quéreas.

MUSÁRIO - E então? Havia de deixar Quéreas, para receber aquele labrego a cheirar a bode? $\mathrm{O}$ meu Quéreas é maciozinho, é, como sói dizer-se, um leitãozinho acarnano.

MÁE - Pois seja: o acarnano é rústico e cheira mal. Mas entấo Antifonte, filho de Menécrates, que te prometia uma mina, porque não o recebeste? Não era também belo, delicado e da mesma idade que Quéreas?

4] MUSÁRIO - Mas Quéreas ameaçou que nos matava a ambos, se alguma vez me apanhasse com ele.

MÃE - Ora ora, quantos outros não fazem tais ameaças? Lá por isso, ficarás sem amantes, menina ajuizada, como se não fosses cortesã, mas sim uma sacerdotisa de Deméter? Mas deixemos isso. Hoje é a Festa das Colheitas. Que é que ele te ofereceu para comemorar?

MUSÁRIO - Ó mamãzinha, ele não tem com quê.

MÃE - Mas será ele o único que não arranjou um expediente contra o pai, que náo mandou um criado para o endrominar, que não exigiu dinheiro à mãe, ameaçando-a de se alistar na marinha, caso ela não lhe dê? Pelo contrário, fica sentado cá em casa, sobrecarregando-nos, sem nos dar dinheiro nem deixar que outros dêem. E tu, querida Musário, cuidas que terás sempre dezoito anos $^{37}$, ou que Quéreas manterá os mesmos sentimentos, quando ficar rico e sua mãe lhe arranjar um casamento de muitos talentos? Julgas que ele, à vista de um dote para aí de cinco talentos, ainda se lembrará das lágrimas, dos beijos ou dos juramentos?

MUSÁRIO - Lembrar-se-á, sim, como se prova pelo facto de, ainda há pouco, não se ter casado: apesar de muito instado e pressionado, recusou.

MÁE - Oxalá ele não te engane, pois nesse dia, querida Musário, avivar-te-ei a memória.

\footnotetext{
${ }^{37}$ Algumas ediçōes têm «dezasseis».
} 


\section{AMPÉLIDE E CRÍSIDE}

1] AMPÉLIDE - Aquele homem que não tem ciúmes da mulher, que não se encoleriza com ela, que não the dá bofetadas, que não lhe puxa os cabelos e não lhe rasga a roupa, será que ainda está apaixonado?

CRÍSIDE - Mas entấo serão essas as únicas provas de amor?

AMPÉLIDE - Sim, esse comportamento é próprio de um homem apaixonado. $\mathrm{Na}$ verdade, tudo o resto, como beijos, lágrimas, juramentos e visitas frequentes, são sinais de um amor na fase inicial e ainda em crescimento. Todavia, o fogo completo manifesta-se com o ciúme. Assim, se Górgias, como afirmas, te bate e tem ciúmes de ti, deves ter esperança e fazer votos por que ele se comporte sempre da mesma maneira.

CRÍSIDE - Sempre da mesma maneira? Que estás para aí a dizer? Sempre a bater-me?

AMPÉLIDE - Não, mas que fique irritado, se tu não tiveres olhos só para ele, pois, se ele não estivesse apaixonado, por que razão havia de se encolerizar pelo facto de tu teres outro amante?

CRÍSIDE - E é que não tenho mesmo. Ele é que suspeitou de que um certo ricaço estava apaixonado por mim, só porque, sem qualquer significado, calhou eu tê-lo mencionado.

2] AMPÉLIDE - Também não deixa de ser agradável que ele suspeite de que tu és pretendida por um homem rico. Deste modo, afligir-se-á ainda mais e esforçar-se-á por que os seus rivais não levem a melhor sobre ele.

CRÍSIDE - No entanto, ele só faz é irritar-se e bater-me, mas não me dá nada.

AMPÉLIDE - Há-de dar, sim, pois é ciumento... e sobretudo se tu o fizeres sofrer.

CRÍSIDE - Mas, não sei lá porquê, Ampélide, tu queres que eu apanhe pancada dele.

AMPÉLIDE - Nada disso, mas, segundo creio, é assim que nascem os grandes amores, [ou seja,] quando o homem se convence de que está a ser desprezado; pelo contrário, se ele julgar que é o único a possuir-te, a sua paixão vai murchando. Quem te dá estes conselhos é uma cortesã que já vai com vinte anos de ofício, ao passo que tu tens, segundo creio, dezoito anos de idade, ou ainda menos. Se quiseres, contar-te-ei o que se passou comigo ainda não há muitos anos. Demofanto, o usurário que mora por 
detrás do Pórtico ${ }^{38}$, estava apaixonado por mim. Ora, este fulano nunca me tinha dado mais do que cinco dracmas, mas julgava-se meu amo e senhor. Amava-me, minha Críside, com um amor muito superficial, sem nunca soltar suspiros nem lágrimas, sem ficar postado fora de horas à minha porta; só vinha para dormir comigo, e mesmo assim de longe em longe.

3] Ora, uma vez em que ele veio visitar-me, deixei-o ficar na rua, pois tinha dentro de casa o pintor Cálides, que me havia enviado dez dracmas. Primeiro, foi-se embora, muito ofendido; depois, tendo passado muitos dias sem que eu o tivesse mandado chamar (pois Cálides ainda estava em minha casa), Demofanto, já muito esquentado e inflamado com o caso, ficou postado à porta, esperando que ela se abrisse: chorou, bateu-me, ameaçou matar-me, rasgou-me o vestido... náo houve nada que ele não fizesse. Por fim, deu-me um talento e ficou comigo só para ele durante oito meses completos. A mulher dele dizia a toda a gente que eu o teria enlouquecido com drogas, mas a única droga era o ciúme. Portanto, Críside, usa esta droga com Górgias. Esse jovem vai ficar rico, se acontecer alguma coisa a seu pai.

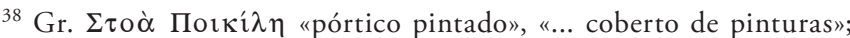
em forma reduzida, podia usar-se só uma das palavras. Aqui é a segunda, que, adaptada ao port., daria Pécile; entendemos traduzir por "Pórtico". 


\section{Dórcade ${ }^{39}$, PaníQuide, Filóstrato e Pólemon}

1] DÓRCADE - Estamos perdidas, minha senhora, estamos perdidas! Pólemon chegou da guerra muito rico, segundo se diz. Eu própria acabo de vê-lo, coberto com um manto bordado a púrpura e com um grande séquito atrás. Assim que o viram, os amigos correram para ele a abraçá-lo. Então eu, vendo logo atrás dele o criado que o tinha acompanhado na expediçấo, primeiro cumprimentei-o e depois perguntei-lhe: «Diz-me cá, Parmenonte, como vos correram as coisas? Que coisa boa trouxestes lá da guerra?"

PANÍQUIDE - Náo devias entrar logo assim, mas de outro modo, como por exemplo: "Chegastes sãos e salvos, graças aos deuses, especialmente graças a Zeus Protector dos Estrangeiros e a Atena Guerreira. A minha patroa andava sempre a querer saber como vocês se encontram, onde é que estavam». E se a isto tu acrescentasses que ela andava chorosa e sempre a lembrar-se de Pólemon, ainda seria muitíssimo melhor.

2] DÓRCADE - Mas foi precisamente tudo isso que eu comecei logo por lhe dizer, mas não tencionava repetir-te, pois o que eu pretendia era contar-te o que ouvi; de facto, comecei por dizer assim a Parmenonte: "Ó Parmenonte, por acaso vós não sentistes as orelhas a zumbir. ${ }^{20} \mathrm{Sim}$, a minha patroa estava sempre a lembrar-se de vós, toda chorosa, principalmente quando chegava alguém do campo de batalha e se dizia que tinha morrido muita gente; então arrepelava os cabelos, batia no peito desatava a chorar a cada notícia.»

PANíQUIDE - Muito bem, Dórcade, isso mesmo é que era preciso.

DÓRCADE - Só logo a seguir é que lhe fiz aquela pergunta, ao que ele respondeu: "Voltámos deslumbrantemente. ${ }^{41}$ "

PANÍQUIDE - O quê? Então ele não disse, antes de mais, que Pólemon se lembrava de mim a toda a hora, que tinha saudades minhas e fazia votos por me encontrar viva?

${ }^{39} \mathrm{O}$ nome significa "Gazela»; Paníquide faz referência a "toda a noite»; Pólemon lig-se a pólemos "guerra».

${ }^{40}$ É pelo menos curiosa a ideia de que, quando alguém ausente está a pensar em nós, sentimos as orelhas a zumbir (ou a arder).

41 "deslumbrantemente» é tradução à letra; poderíamos dizer «em beleza»... 
DÓRCADE - Sim, com certeza, que disse muitas coisas desse género... mas o principal é que anunciou que trazia uma enorme fortuna em ouro, vestuário, criados, marfim... e que o patrão não contava o dinheiro em prata à peça, mas media-o em medimnos ${ }^{42}$ inteiros. Parmenonte até tinha no dedo mínimo um anel enorme, multifacetado, com uma pedra tricolor nele cravada e com a face superior vermelha. Quando o deixei, queria contar-me como haviam atravessado o rio Hális, como tinham morto um tal Tiridatas e como Pólemon se tinha distinguido na batalha contra os Písidas... mas eu afastei-me a correr, a fim de te dar as notícias, para que reflictas sobre a presente situação. $\mathrm{Na}$ verdade, se Pólemon aqui vier (e certamente virá, depois de se desembaraçar dos conhecidos), se perguntar o que se passa e der com Filóstrato cá em casa, que achas que ele fará?

3] PANÍQUIDE - Ó Dórcade, temos de encontrar, uma forma de nos safarmos desta situação: de facto, não é decente pôr na rua Filóstrato, que ainda outro dia me deu um talento e que, de resto, é um mercador e me promete muitos presentes; mas, por outro lado, não seria lucrativo deixar de receber Pólemon, que regressa numa situaçáo destas, tanto mais que ele é muito ciumento; além disso, se, quando ele era pobre, era insuportável, que é que ele agora não faria?

DÓRCADE - Aí vem ele.

PANÍQUIDE - Ó Dórcade, sinto-me desfalecer de ansiedade, toda eu tremo.

DÓRCADE - Filóstrato também vem aí.

PANÍQUIDE - Que vai ser de mim? Antes queria que a terra me tragasse.

4] Filóstrato - Então, Paníquide, porque não nos dás de beber?

PANÍQUIDE - Ó homem, tu és a minha desgraça! E tu... Ora viva, Pólemon, que há tempos náo aparecias.

PÓlEMON - Mas quem é este tipo que entrou cá em casa? Não dizes nada? Pois bem, Paníquide, passa muito bem. E vim eu voando das Termópilas aqui em cinco dias, a toda a pressa, ansioso por ver uma mulher destas! Pois foi bem feito o que me aconteceu, e até te agradeço, pois nunca mais me hás-de explorar.

FILÓSTRATO — E tu quem és, ó valentão?

${ }^{42}$ Medida de capacidade para sólidos: 1 medimno = c. 39 litros. 
PÓlEMON - Fica sabendo que sou Pólemon, do demo de Estíria e da tribo de Pândion, em tempos quiliarca ${ }^{43}$, e agora comandante de uma força de cinco mil escudeiros, amante de Paníquide, no tempo em que ainda julgava que ela tinha sentimentos humanos.

FILÓSTRATO - Mas agora, senhor capitão de mercenários ${ }^{44}$, Paníquide é minha, já recebeu um talento e vai em breve receber outro, assim que eu vender a mercadoria. Agora, Paníquide, vem daí comigo e deixa este sujeito ser quiliarca entre os Ódrisas ${ }^{45}$.

PÓLEMON - Paníquide é uma mulher livre, só irá contigo se ela quiser.

PANÍQUIDE - Que fazer, Dórcade?

DÓRCADE - É melhor ir para casa, pois não convém que te aproximes de Pólemon, furioso como ele está; além disso, ficaria ainda mais ciumento.

PANÍQUIDE - Se assim te parece, entremos.

5] PÓlEMON - Pois aviso-vos que é hoje a última vez que bebereis juntos, ou foi em vão que eu me treinei em tais massacres. Já para aqui os Trácios, Parmenonte! Que venham armados e que obstruam a rua com uma falange! $\mathrm{Na}$ frente-centro, os hoplitas, de um lado e do outro os fundibulários e os arqueiros, e os restantes atrás!

FILÓSTRATO - Ó meu mercenário, cuidas que estás a falar a criancinhas, assim a fazer de papão? Será que já alguma vez mataste um galo ou viste sequer uma guerra? Talvez comandante da guarda de um posto... e já é um favor que te faço.

PÓLEMON - Dentro em breve o saberás, quando nos vires avançar pelo flanco direito e com as armas rebrilhantes.

FILÓSTRATO - Vinde entáo todos preparados, que eu mais aqui o Tibio, que é o único criado que me acompanha, desbaratar-vos-emos à pedrada e à caqueirada, de tal modo que nem sabereis para onde escapar.

${ }^{43}$ Lit. $^{\text {te }}$ "comandante de uma força de 1.000 homens; em Roma (época de Luciano) correspondia a tribunus militum. Havia seis tribuni militum (ou $t$. militares) por legiáo.

${ }^{44} \mathrm{Ou}$ «... de infantaria», mas a outra designação é mais claramente depreciativa.

45 Povo da Trácia. 
(Página deixada propositadamente em branco) 


\section{QUELIDÓNIO ${ }^{46}$ E Dróside}

1] Quelidónio - Ó Dróside, então aquele rapazote, o Clínias, já não te visita? $\mathrm{Na}$ verdade, há muito tempo que não o vejo em tua casa.

DRÓSIDE - Já não, querida Quelidónio, pois o seu mestre impede-o de se aproximar de mim.

QUELIDÓNIO - Quem é ele? Estarás tu a referir-te a Diotimo, o professor de ginástica? É que esse é meu amigo.

DRÓSIDE - Não, trata-se do mais execrável dos filósofos, raios o partam, um tal Aristéneto.

QUELIDÓNIO - Referes-te àquele tipo de olhar sombrio, de cabelos revoltos e barbudo, que costuma deambular no Pórtico acompanhado de jovenzinhos?

DRÓSIDE - É esse mesmo a quem me refiro, esse charlatão, que eu gostaria de ver morto de má morte, com o carrasco a arrastá-lo pela barba.

2] QUELIDÓNIO - Mas por que artes é que ele persuadiu Clínias a agir assim?

DRÓSIDE - Não sei, querida Quelidónio, mas [o que é certo é que] Clínias, que, desde que começou a ter relaçóes com uma mulher (e fui eu quem o iniciou nisso), nunca tinha passado uma noite longe de mim, já vai em três dias seguidos que não aparece nesta rua. Então eu, inquieta e sem saber o que pensar do caso, mandei a Nébrida investigar se ele passava o tempo na Ágora ou no Pórtico. Ela comunicou-me que o tinha visto a passear com Aristéneto e que lhe tinha feito, de longe, um sinal, mas ele ficou vermelho, baixou a cabeça e nunca mais voltou os olhos para ela. Depois, encaminharam-se ambos, aluno e professor, para a Academia. Então ela seguiu-os até ao Dípilo, mas, como o moço nunca voltasse o rosto na sua direcção, regressou a casa sem ter nada de concreto para contar. Como é que tu julgas que eu tenho passado depois disso, sem poder imaginar o que se passa com o jovenzinho? E dizia [comigo mesma:] «Será que o aborreci nalguma coisa? Ou desgostou-se de mim e agora está apaixonado por outra qualquer? Ou foi seu pai que o proibiu [de me visitar]?» Estava eu, infeliz de mim, matutando nestes pensamentos, e eis

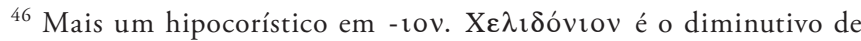
$\chi \varepsilon \lambda \imath \delta \omega ́ v$ "andorinha», que, em port. já tem ressonância diminutiva; o nome Dróside está relacionado com $\delta \rho o ́ \sigma o \varsigma$ «orvalho». 
que, já ao cair da noite, chegou Drómon, que me trazia este bilhetinho da parte dele. Pega nele e lê-mo, querida Quelidónio..., pois julgo que sabes ler.

3] QUELIDÓNIO — Então vejamos. As letras não estão muito legíveis, mas sim arrastadas, revelando a pressa de quem escreveu. Diz o bilhete: "Dróside, tomo os deuses por testemunhas de como eu te amei..."

DRÓSIDE - Oh desgraçado, que nem sequer começa por me saudar ${ }^{47}$.

QUELIDÓNIO - "...Mas agora tenho de me separar de ti, não por te odiar, mas porque a isso sou obrigado. É que meu pai confiou-me a Aristéneto, a fim de estudar filosofia com este mestre, e ele, informado de tudo o que se passava entre nós, censurou-me vivamente, dizendo que era indecoroso que eu, filho de Arquiteles e de Erasiclia, vivesse com uma cortesä, pois era muito melhor preferir a virtude ao prazer...».

DRÓSIDE - Raios partam esse [velho] tonto que ensina tais coisas ao mocinho.

QUELIDÓNIO - «... Deste modo, sou obrigado a obedecer-lhe, pois ele segue-me de perto e vigia-me severamente; em resumo: não me é permitido olhar para qualquer outra pessoa que não seja ele. Além disso, promete-me que, se eu tiver juizo e lhe obedecer em tudo, serei muitissimo feliz e, uma vez exercitado no sofrimento, tornar-me-ei uma pessoa virtuosa. Foi a muito custo e às escondidas dele que escrevi estas palavras. Desejo-te boa sorte e que te lembres de Clinias.»

4] DRÓSIDE - Que te parece esta carta, querida Quelidónio?

QUELIDÓNIO - É quase tudo palavreado à maneira dos Citas, mas aquela frase "Lembra-te de Clinias» deixa ainda alguma esperança.

DRÓSIDE - Também me pareceu. Mas morro de amores. De facto, Drómon afirma que Aristéneto é um pederasta, que, a pretexto das liçóes, tem relaçóes com os jovens mais formosos; que até já tem conversado em particular com Clínias, fazendo-lhe umas certas promessas... que o tornaria igual aos deuses... Além disso, lê com o moço certos diálogos eróticos dos filósofos antigos

${ }^{47}$ As cartas começavam com uma fórmula mais ou menos fixa, que,

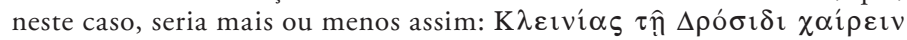
"Clónias saúda Dróside». 
aos seus discípulos; enfim, anda embevecido com o mocinho. Drómon até o ameaçou de ir contar tudo ao pai de Clínias.

QUELIDÓNIO - Ó Dróside, tu devias encher bem a barriga de Drómon.

DRÓSIDE - Sim, enchi, mas, mesmo sem isso, ele ser-me-ia fiel, pois também está louco por Nébride.

QUELIDÓNIO - Anima-te, que tudo há-de correr bem. Por minha parte, creio que vou escrever no muro do Ceramico, onde Arquíteles costuma passear, "Aristéneto corrompe Clínias", de maneira que esta frase coincida com a acusação de Drómon.

DRÓSIDE - E como é que escreverás isso sem que te vejam?

QUELIDÓNIO - Ó Dróside, arranjo um pedaço de carvão em qualquer lado e vou lá de noite.

DRÓSIDE - Bravo, querida Quelidónio, oxalá me ajudes nesta guerra contra esse charlatão do Aristéneto. 
(Página deixada propositadamente em branco) 


\section{Trifena e Cármides}

1] TRIFENA - Já alguma vez se viu um homem tomar uma cortesá, pagar-lhe um salário de cinco dracmas e depois deitar-se e voltar-lhe as costas, não fazendo senão chorar e gemer? Não bebias com prazer e eras o único que não queria comer; durante toda a ceia, só choravas, que eu bem vi. Mesmo agora, não deixas de chorar como uma criança. Então, Cármides, porque procedes assim? Não me ocultes nada, para que, pelo menos, eu tire alguma vantagem da noite em claro que passei contigo.

CÁRMIDES — Ó Trifena, a paixão acaba comigo, já não posso mais contra a sua violência.

TRIFENA - Bem, é evidente que não é por mim que estás apaixonado, pois não mostrarias desprezo por mim, nem me afastarias quando eu quero abraçar-te, nem porias, com o manto, como que uma barreira entre nós, com receio de que eu te tocasse. Mas entâo... diz-me cá quem é essa mulher; talvez eu possa, de algum modo, contribuir para esse amor, pois conheço truques para ajudar nessa matéria.

CÁRMIDES - Na verdade, tu conhece-la muito bem, e ela a ti, pois trata-se de uma cortesá bem conhecida.

2] TRIFENA - Mas, ó Cármides, como é que ela se chama?

CÁRMIDES - Chama-se Filemácio ${ }^{48}$, Trifena.

TRIFENA - A qual delas te referes? Realmente, há duas [com esse nome]: uma do Pireu, que há pouco tempo perdeu a virgindade e é amante de Dâmilo, filho do actual general, ou uma outra, a quem alcunham de Págide ${ }^{49}$.

CÁRMIDES - Essa mesma. E eu, desgraçado, deixei-me cair e fui apanhado por ela.

TRIFENA - Então é por essa mulher que tu choras?

CÁRMIDES - É, pois.

TRIFENA — E há muito tempo que estás apaixonado por ela, ou é uma coisa recente?

CÁRMIDES - Não é coisa recente, não, mas data de há quase sete meses, desde as Dionisíacas, que foi quando eu a vi pela primeira vez.

${ }^{48}$ Filemácio ( $\varphi i ́ \lambda \eta \mu \alpha$ «beijo»; mais uma vez, a adaptação rigorosa em port. não sai bem.

${ }^{49}$ Literalmente, "armadilha»; a seguir se mostra o porquê dessa alcunha; difícil é verter o jogo de ideias, pois o nome Págide não nos diz nada. 
TRIFENA - Mas viste-a mesmo toda [nua], ou de Filemátio só viste a cara e as partes do corpo que estão mesmo à vista, como convém a uma mulher já com quarenta e cinco anos?

CÁRMIDES - Mas ela jura que vai completar vinte e dois anos no próximo mês de Elafebólion ${ }^{50}$.

3] TRIFENA - E tu em qual das duas coisas acreditarias: nos juramentos dela ou nos teus próprios olhos? Examina bem, olhando pela parte de baixo, as suas têmporas, que é o único sítio onde ela tem cabelos naturais; o resto não passa de um chinó muito espesso; mas na zona das têmporas, logo que se esvai a coloraçáo da tinta com que se pinta, aparecem os cabelos brancos. Mas... para quê tudo isto? Insiste com ela para que te deixe vê-la toda nua.

CÁRMIDES - Nunca se prestou a fazer-me esse favor.

TRIFENA — Naturalmente! Ela bem sabia que tu ficarias horrorizado com as manchas brancas, pois, desde o pescoço até aos joelhos, parece um leopardo. E ainda tu choravas por não estares junto dela?! Porventura também ela te afligiu e te desprezou?

CÁRMIDES - Sim, Trifena, apesar de tantos presentes que recebia de mim. Ainda agora, porque náo tinha ali à mão mil dracmas para lhe dar, pois sou criado por um pai muito forreta, ela recebeu Mósquion e deixou-me a mim na rua. Então eu, para me vingar, resolvi também desgostá-la e escolhi-te a ti.

TRIFENA - Por Afrodite! eu não teria vindo, se me tivessem avisado de que era escolhida para este efeito, para desgostar outra mulher, sobretudo Filemátio, essa urna funerária. Bem, vou-me embora, pois o galo já cantou três vezes.

4] CÁRMIDES - Ó Trifena, não te vás com tanta pressa: se é verdade o que dizes a respeito de Filemátio - que usa chinó, que se pinta, e mais aquilo das manchas brancas - , nunca mais poderei olhar sequer para ela.

TRIFENA - Pergunta à tua mãe, se é que já tem estado no balneário com ela; e quanto à sua idade, talvez o teu avô te conte alguma coisa, se ainda é vivo.

CÁRMIDES - Pois então, se ela é assim, retire-se já neste momento a 'barreira's1, abracemo-nos, beijemo-nos e fiquemos verdadeiramente juntos. Quanto a Filemátio, que passe muito bem.

${ }^{50}$ Corresponde a Março.

${ }^{51}$ Sobre o sentido deste termo, v. $\$ 1$ ( $2^{\text {a }}$ fala de Trifena). 


\section{IOesSa ${ }^{\varsigma 2}$, Pítias E Lísias}

1] IOESSA - Ó Lísias, então agora fazes-te caro comigo? Muito bonito! E logo comigo, que nunca te exigi dinheiro nem te deixei ficar à porta, quando tu cá vinhas, dizendo que tinha outro cá em casa, nem te induzi a enganar o teu pai ou a roubar a tua mãe, a fim de me trazeres qualquer coisa, como fazem as outras; pelo contrário, desde sempre que eu te tenho recebido sem pagar e sem entrares com a tua parte [nas festas]... e tu bem sabes quantos amantes eu mandei embora: Téocles, que agora é prítane $^{53}$, Pásion, o armador, e o teu companheiro Melisso, apesar de lhe ter morrido o pai há pouco tempo e ele ter ficado na posse da herança. Só eu é que fiquei sempre com o meu Fáon ${ }^{54}$, sem olhar para nenhum outro homem e sem me aproximar de qualquer outro que não tu. $\mathrm{Na}$ verdade, cuidava eu, a palerma, na sinceridade dos teus juramentos e, por causa disso, mantinha-me ajuizada como Penélope, apesar de minha mãe me criticar e me censurar perante as suas ${ }^{55}$ amigas. Então tu, sentindo que me tinhas na máo e que eu estava perdida de amor por ti, ora te divertias com Licena, na minha presença, só para me aborreceres, ora fazias o elogio da citarista Magídio, quando estavas deitado ${ }^{56}$ comigo. É por isso que eu choro e me sinto ofendida. Aqui há dias, quando tu bebias na companhia de Tráson e de Dífilo, estavam presentes a flautista Cimbálio e Pirálide, minha grande inimiga, como tu bem sabes. Náo me importei muito por tu teres beijado Cimbálio cinco vezes, pois foi a ti que tu ofendeste ao beijar uma tal mulher. Mas quantos sinais fazias a Pirálide! Ao beber, dedicavas a taça à sua saúde e, ao devolver a taça ao criado, ordenavas-lhe ao ouvido que não enchesse para mais ninguém, sem que Pirálide mandasse. Por fim, deste uma dentada numa maçã e, logo que viste que Dífilo estava distraído a conversar com Tráson, atiraste-a com precisão ao peito da outra, sem sequer tentares fazer com que eu não desse por isso. Entấo

${ }^{52} \mathrm{Gr}$. ió $\varepsilon \sigma \sigma \alpha$ significa "(que tem cor de) violeta», "morena».

53 Os prítanes eram membros do Conselho dos 500, ou Senado. A sua eleição era anual.

${ }^{34}$ Jovem de Lesbos, amado de Safo.

55 O texto é ambíguo: "suas» ou "minhas».

56 Pode entender-se "deitado na cama» ou «reclinado à mesa». 
a fulana deu um beijo na maçã e enfiou-a por entre as mamas ${ }^{57}$, por debaixo do apara-seios ${ }^{58}$.

2] Porque te comportas assim? Que ofensa ou desgosto, grande ou pequeno, te causei? Olhei para algum outro homem? Não vivo eu só para ti? Ó Lísias, que grande proeza cometes, afligindo uma pobre mulher que está louca por ti! Mas [lembra-te de que] existe uma deusa chamada Adrastia ${ }^{59}$, que vê actos como este. Talvez um dia venhas a arrepender-te, ao ouvir dizer que eu morri, quer me tenha enforcado com uma corda de nó corrediço, quer me tenha atirado de cabeça para dentro de um poço, quer tenha encontrado qualquer outro género de morte, para náo te importunar com a minha presença. Então poderás vangloriar-te de ter cometido uma grande e brilhante proeza. Porque me olhas de través e ranges os dentes? Se tens alguma coisa a apontar-me, fala; aqui a Pitíade será a nossa juíza. Mas... que é isso? Não respondes, vais-te embora e deixas-me aqui? Estás a ver, Pitíade, como Lísias me trata?

PITÍADE - Ó que crueldade! Ele não se comove com as tuas lágrimas: é uma pedra, não um homem. Mas, para dizer a verdade, foste tu, Ioessa, que o estragaste, amando-o em excesso e mostrando-lhe isso mesmo. Pelo contrário, não devias apegar-te tanto a ele, pois os homens ficam muito orgulhosos quando se apercebem desses sentimentos. Pára de chorar, infeliz, dá-me ouvidos e, quando ele vier visitar-te, deixa-o ficar uma ou duas vezes plantado na rua, e então verás como ele fica todo inflamado e também ele completamente louco.

IOESSA - Não digas uma coisa dessas! Vai-te daqui! Deixar Lísias na rua? Oxalá não seja ele o primeiro a separar-se de mim.

PITÍADE - Mas ei-lo que volta atrás.

IOESSA - Ai que me desgraçaste, Pitíade! Ele deve ter-te ouvido dizer "Deixa-o ficar plantado na rua".

3] LÍSIAS - Pitíade, voltei atrás, não por causa desta mulher, que não quero ver na minha frente enquanto ela for como é, mas por causa de ti, para que não me condenes nem digas: "Lisias é um homem implacável».

PITÍADE — Pois foi isso mesmo que eu disse.

57 Esta cena da maçã tem um significado erótico evidente.

58 É a peça a que em francês se chama soutien-gorge.

${ }^{59}$ Nome menos vulgar de Némesis, deusa vingadora de actos ímpios... 
LÍsIAS - Queres então, Pitíade, que eu condescenda com esta Ioessa, que agora está toda chorosa, mas que eu outro dia surpreendi a atraiçoar-me, deitada com outro jovem?

PITÍADE - Ó Lísias, afinal de contas, ela é uma cortesá... Mas em que circunstâncias os surpreendeste deitados na cama?

LÍSIAS - Faz agora para aí uns seis dias, sim, por Zeus!, mesmo seis, pois estávamos no dia dois do mês, e hoje é dia sete. Ora, meu pai, sabendo da minha paixão por esta lindinha, fechou-me em casa, dando ordens ao porteiro para que não me abrisse a porta. Então eu, não suportando passar sem vir ter com ela, ordenei a Drómon que se baixasse junto do muro do pátio, no sítio onde ele é mais baixo, e me deixasse subir-lhe para as costas, pois assim seria mais fácil de escalar. Mas para quê alongar-me? Saltei o muro e dirigi-me para cá, tendo encontrado a porta de entrada cuidadosamente fechada, pois já era meia-noite. Por isso, não bati, mas, tendo erguido ligeiramente a porta, como fizera noutras ocasióes, e tendo-as feito rodar nos gonzos, entrei muito de mansinho. Estava toda a gente a dormir. Depois, às apalpadelas na parede, chego junto da sua cama.

4] IOESSA — Por Deméter! Que é que vais dizer? Estou ansiosa. LÍSIAS - Como não sentia somente uma respiração, primeiro pensei que ela estava a dormir com Lide; mas não era isso, Pitíade, pois, tendo apalpado, percebi que era alguém com um queixo sem barba e muito macio, uma cabeça completamente rapada e exalando perfume. Ao dar com esta situação, ah! se eu tivesse trazido a minha espada, não hesitaria, fica sabendo. Mas, ó Pitíade, porque estáo vocês a rir? Será para rir a história que estou a contar-vos?

IOESSA — Ó Lísias! Então foi isso que te desgostou? Era aqui a Pitíade quem estava deitada comigo.

PITÍADE - Não lhe contes nada, Ioessa.

IOESSA - Não lhe conto porquê? Era Pitíade, pois, meu querido, a quem eu pedi que viesse dormir comigo, pois estava triste por nấo te ter comigo.

5] LÍsIAS - Era então Pitíade a pessoa de cabeça rapada? E como é que em seis dias lhe cresceu uma cabeleira tão grande?

IOESSA - Sabes, Lísias, ela rapou o cabelo devido a uma doença que lhe provocava a queda do cabelo. Agora pôs uma 
peruca. Mostra-lhe lá, Pitíade, prova-lhe que é tal e qual como eu digo, convence-o. Eis o mocinho adúltero de quem tinhas ciúmes. LÍsIAS - E não tinha motivo para tal, Ioessa, tanto mais que estava apaixonado e, além disso, lhe toquei com as minhas próprias mãos?

IOESSA - Portanto, agora já estás convencido. Queres que me vingue dos desgostos que me causaste? Estou no meu direito de também estar furiosa.

LÍSIAS - De maneira nenhuma, mas antes vamos beber, e Pitíade connosco, pois é justo que ela assista ao nosso armistício. IOESSA - Assistirá, pois. Oh! O que eu padeci por tua causa, ó Pitíade, $o$ mais encantador dos jovens! ${ }^{60}$

PITÍADE - Mas também fui eu mesmo que vos reconciliei um com o outro. Por isso, não fiques zangado comigo. Só uma coisa te peço, Lísias: não contes a ninguém isto da minha cabeleira.

${ }^{60}$ Aqui e na fala seguinte, insiste-se na caracterização de Pitíade como rapaz. 


\section{LeÔNTICo, QUÉNIDAS E HímNide}

1] LEÔNTICO - Conta lá, ó Quénidas, como é que eu, na batalha contra os Gálatas, irrompi de entre a nossa cavalaria, montado no meu cavalo branco, e como é que os Gálatas, apesar de serem [guerreiros] corajosos, ficaram aterrorizados assim que me viram, de tal modo que nenhum ousou fazer-me frente ${ }^{61}$. Então eu, atirando a lança como se fosse um dardo, trespassei de um só golpe o próprio Hiparco ${ }^{62}$ e o seu cavalo. Depois, desembainhei a espada, virei-me com toda a alma para os que ainda resistiam (pois restavam ainda uns quantos, os quais, tendo desfeito a falange, se agruparam em quadrado) e derrubei, só com o choque do meu cavalo, uns sete dos seus comandantes. A seguir, brandindo a minha espada de alto a baixo, rachei em duas a cabeça de um dos comandantes, com elmo e tudo. Pouco depois chegaste tu, Quénidas, já eles estavam em debandada.

2] QUÉNIDAS - Sim, sim, Leôntico. E daquela vez, na Paflagónia, em que tu lutaste com o sátrapa em combate corpo a corpo, não te exibiste também em grande?

LEÔNTICO - Ainda bem que lembraste essa minha mui nobre façanha. De facto, o sátrapa, homem de enorme estatura e considerado o melhor de todos os guerreiros [de arma pesada] e que menosprezava as tropas gregas, saltou para o terreno entre os dois exércitos, desafiando quem quisesse lutar com ele em combate singular. Todos ficaram transidos de medo, comandantes de companhia, comandantes de divisão, e até o nosso general, que não era homem falho de coragem: de facto, estávamos sob o comando de Aristecmo, natural da Etólia, que manejava o dardo como ninguém, enquanto eu era ainda quiliarca. Então eu, cheio de coragem, afasto os amigos que queriam segurar-me, pois temiam pela minha vida, ao verem o bárbaro rebrilhando nas suas armas douradas, grande e aterrador no seu penacho e brandindo a lança.

QUÉNIDAS — Também eu, Leôntico, fiquei aterrorizado; bem sabes como eu me agarrava a ti, suplicando-te que não te arriscasses pelos outros, pois, se tu morresses, a minha vida não teria sentido.

${ }^{61}$ Outra interpretação: «... se manteve firme (no seu posto)».

62 "comandante de cavalaria». 
3] LEÔNTICO - Mas eu avancei corajosamente para o meio da arena, envergando um armamento em nada inferior ao do paflagónio, mas todo dourado, de tal modo que se ouviu um clamor, quer da nossa parte, quer do lado dos bárbaros, pois, ao verem-me, tinham-me reconhecido sobretudo pelo escudo, pelo arnês [do cavalo] e pelo penacho. Diz lá, Quénidas, com quem é que toda a gente me comparava?

QUÉNIDAS - Com quem havia de ser, por Zeus!, senão com Aquiles, filho de Tétis e de Peleu? O elmo assentava-te tão bem, as vestes de púrpura bordadas com flores, o escudo resplandecente!

LEÔNTICO - Logo que nos chegámos um ao outro, o bárbaro foi o primeiro a ferir-me, atingindo-me ao de leve com a lança, um pouco acima do joelho; depois eu, atravessando-lhe o escudo com a lança ${ }^{63}$, firo-o em pleno peito; a seguir, corri para ele, degolei-o com toda a facilidade com um golpe de espada, despojei-o das armas e retirei-me, com a sua cabeça espetada na ponta da lança e coberto de sangue.

4] Hímnide - Basta, Leôntico! O que me estás a contar a teu respeito é repugnante e terrível: nenhuma mulher poderia olhar para ti, que te comprazes assim tanto com chacinas, nem beber e dormir contigo. Pois eu vou-me daqui.

LEÔNTICO - Eu pago-te o dobro do dinheiro.

HímNIDE - Não suportaria dormir com um assassino.

LEÔNTICO - Não tenhas medo, Hímnide; estas coisas passaram-se no país dos Paflagónios, mas agora estou em [tempo de] paz.

HímNIDE - Mas tu és um homem maldito, pois gotejava sobre ti o sangue da cabeça do bárbaro, que tu levavas na ponta da lança. Depois disto, poderei eu abraçar e beijar um tal homem? Que as Graças me livrem! Sim, que este homem não é melhor que um carrasco.

LEÔNTICO - E no entanto, se tu me visses com o meu armamento, tenho a certeza de que ficarias apaixonada.

HímNIDE - Só de ouvir-te, Leôntico, fico com náuseas e toda arrepiada; parece-me ver as sombras e os fantasmas dos homens assassinados, sobretudo daquele pobre comandante a quem rachaste a cabeça em duas. Que julgas [que aconteceria], se eu tivesse assistido a essa cena e visto o sangue e os cadáveres

${ }^{63} \sigma \alpha ́ \rho \imath \sigma \alpha$ é uma lança macedónica muito comprida (14-16 pés). 
jazentes pelo campo? Julgo que morreria, eu que nunca vi sequer matar um galo.

LEÔNTICO - Ó Hímnide, és assim tão medrosa e fraca de espírito? E eu que cuidava que tu te deleitarias ao ouvir-me.

HíMNIDE - Vai mas é deleitar com as tuas histórias certas mulheres de Lemnos ou as Danaides ${ }^{64}$ que encontres, que eu vou já daqui a correr para casa de minha mãe, enquanto ainda é de dia. Segue-me, Grámide. E tu, bravo quiliarca e matador de quantos [inimigos] quiseres, passa muito bem.

5] LEÔNTICO — Fica aqui, Hímnide, fica... Oh! Foi-se embora.

QUÉNIDAS - Pois claro, Leôntico: aterrorizaste uma menina simples, agitando penachos e contando façanhas incríveis. Eu bem vi como ela, logo de início, ficou pálida, enquanto tu contavas aquela cena do comandante, e depois contraiu o rosto e ficou toda arrepiada, quando tu contaste que lhe tinhas cortado a cabeça.

LEÔNTICO - É que eu pensava que assim lhe pareceria mais apetecível; mas tu, Quénidas, também contribuíste para me tramar, sugerindo-me aquela do combate singular.

QUÉNIDAS - Porventura não devia eu ajudar-te a mentir, vendo o motivo da sua fanfarronice? Tu é que tornaste a coisa mais pavorosa. Sim, que tenhas cortado a cabeça do pobre paflagónio, vá que não vá... mas porque é que lha espetaste na ponta da lança, de modo que o sangue escorresse para cima de ti?

6] LEÔNTICO — Esta última foi uma coisa verdadeiramente infame, Quénidas, embora, no geral, a história não estivesse nada mal arquitectada. Portanto, vai lá e convence-a a vir dormir comigo.

QUÉNIDAS - Digo-lhe que foi tudo mentira tua, no intuito de lhe pareceres destemido?

LEÔNTICO - É vergonhoso, Quénidas.

QUÉNIDAS - No entanto, de outro modo ela não viria. Escolhe, pois, de duas uma: ser detestado por ela, fazendo-te passar por um valentáo, ou dormir com Hímnide, mas à custa de lhe confessares que mentiste.

LEÔNTICO - Ambas as coisas são penosas. Em todo o caso, escolho Hímnide. Vai lá então, Quénidas, e diz-lhe que eu lhe menti... mas não por completo!

${ }^{64}$ As Danaides, filhas de Dánao, em número de 50; com excepção de uma, as outras mataram os maridos na noite de núpcias; as mulheres de Lemnos também tinham fama de matar os maridos... 
(Página deixada propositadamente em branco) 


\section{Dórion e Mírtale}

1] DÓRION - Ó Mírtale, então agora pões-me na rua, agora, que fiquei pobre por tua causa?! Mas quando te trazia tantos presentes, era o teu amado, o teu homem, o teu senhor, era tudo para ti. Agora que fiquei completamente «teso" e que tu arranjaste para amante esse comerciante da Bitínia, eu sou posto na rua e fico à tua porta a chorar, enquanto o outro faz amor contigo todas as noites e é o único a ser admitido e a passar a noite em tua casa... até dizes que estás grávida dele.

MíRTAlE - Tudo isso me sufoca, Dórion, principalmente quando dizes que me deste muitos presentes e que ficaste pobre por minha causa. Enumera lá entáo, desde o princípio, todos os presentes que me deste.

2] DÓRION — Pois bem, Mírtale, enumeremos. Em primeiro lugar, uns sapatos de Sícion, por duas dracmas. Assenta aí: duas dracmas.

MíRTAlE - Mas também dormiste comigo duas noites.

DÓRION - E quando regressei da Síria, um frasco de alabastro com perfume da Fenícia, este também por duas dracmas, juro por Posídon.

MíRTALE - Mas também, quando tu embarcaste, eu dei-te aquela túnica curta até às coxas, para que a usasses quando estivesses a remar, e que foi deixada esquecida cá em casa pelo timoneiro Epiuro, quando cá dormiu comigo.

DÓRION - Mas, ainda há pouco tempo, em Samos, Epiuro reconheceu a sua túnica e fez-me despi-la, depois de uma grande briga, meus deuses! ... Também te trouxe cebolas de Chipre, cinco arenques ${ }^{65}$ salgados e quatro percas, quando regressei do Bósforo. Que mais? Oito pães secos ${ }^{66}$ de marinheiro, no seu cestinho, um cabaz de passas de figo da Cária e, finalmente, umas sandálias douradas de Pátara. Minha Ingrata!... Ah!, já me esquecia de um queijo enorme que uma vez te trouxe de Gítio.

MíRTALE - Vá lá... para aí umas cinco dracmas por tudo isso.

3] DÓRION - Ó Mírtale, mas isso é o que eu, simples marinheiro, podia juntar para além do salário. Acabo de ser nomeado

${ }^{65}$ Há certa dificuldade em identificar este peixe...

${ }^{66}$ JDeve tratar-se de biscoitos, secos para aguentarem melhor... 
para dirigir o estibordo do navio, e tu ainda desdenhas de mim... Mas ainda outro dia, por ocasiáo das Afrodisíacas, não lancei aos pés de Afrodite uma dracma de prata em tua intenção? Além disso, dei duas dracmas a tua mãe, para uns sapatos, e muitas vezes tenho passado para a máo aqui de Lide ora dois óbolos, ora quatro. Tudo isto junto faria a fortuna de um marinheiro.

MíRTALE - O quê, Dórion, as cebolas e os arenques?

DÓRION - Sim, pois não tinha mais nada para te trazer. $\mathrm{Na}$ verdade, se eu fosse rico, não seria remador. À minha mãe nunca lhe dei nem sequer uma cabeça de alho. Mas... gostaria de saber que presentes recebeste tu do bitínio.

MíRTALE - Em primeiro lugar, estás a ver esta túnica? Foi ele quem a comprou, bem como este colar muito grosso.

DÓRION - Foi mesmo ele? Mas eu já to conhecia desde há muito tempo...

MíRTALE - Aquele que tu conhecias era mais fino e não tinha esmeraldas. Também [me ofereceu] estes brincos e um tapete e, há pouco tempo, deu-me duas minas e pagou por nós a renda da casa. O que não me deu foram sandálias de Pátara, queijo de Gítio e outras bugigangas.

4] DÓRION - Mas não me dizes como é essa pessoa com quem dormes? Já deve ter passado dos cinquenta, é completamente calvo ${ }^{67} \mathrm{e} \mathrm{tem} \mathrm{pele} \mathrm{cor} \mathrm{de} \mathrm{lagosta}{ }^{68}$. Náo vês os seus dentes? Ó Dioscuros! $!^{69}$ Muitos encantos tem o homem, principalmente quando canta e quer parecer gracioso, tal e qual, como diz o provérbio, «um burro a tocar lira». Pois então, mulher digna de tal homem, que te faça bom proveito ${ }^{70}$ e que vos nasça um menino igual ao pai... Eu hei-de encontrar uma Délfide ${ }^{71}$ ou uma Cimbálio qualquer da minha classe, ou a minha vizinha tocadora de flauta ou qualquer outra. Nem todos temos [possibilidade de dar] tapetes, colares ou presentes de duas minas.

${ }^{67}$ Aqui alterei a pontuação da ed. Loeb.

${ }^{68} \mathrm{Ou}$ "caranguejo".

${ }^{69}$ Os Dioscuros («filhos de Zeus») eram os gémeos Castor e Pólux; heróis nacionais no Peloponeso, também tinham um templo em Atenas...

${ }^{70}$ Há aqui um jogo de palavras talvez impossível de traduzir, entre óvos "burro" e óv $\alpha$ to "que lucres», "que te faça bom proveito".

71 Referência a duas prostitutas menos exigentes, certamente bem conhecidas, e que, por estas duas razóes, são aqui nomeadas. 
MÍRTALE - Ó Dórion, feliz daquela que te tiver como amante, pois hás-de trazer-lhe cebolas de Chipre e queijo, quando regressares de Gítio. 
(Página deixada propositadamente em branco) 


\section{Cóclide e Parténide}

1] CÓCLIDE - Porque choras, Parténide? Donde é que vens, que trazes a flauta ${ }^{72}$ completamente quebrada?

PARTÉNIDE - Foi aquele soldado da Etólia, o grandalhão, amante de Crócale, que me deu bofetadas, por me surpreender a tocar flauta em casa de Crócale, contratada pelo seu rival Gorgo; irrompeu por ali dentro, esmigalhou-me a flauta, virou de pantanas a mesa onde ceavam e despejou o jarrão [do vinho $]^{73}$. Depois, arrastando pelos cabelos para fora da sala esse tal Gorgo, um tipo rude, espancaram-no, ele, o soldado - creio que Dinómaco de seu nome - , e um seu camarada, com tal violência, Cóclide, que não sei se o homem sobreviverá, pois o sangue corria-lhe do nariz e tinha toda a cara inchada e muito lívida.

2] CÓCLIDE - Terá o homem endoidecido ou foi efeito da bebedeira e da excitação do vinho?

PARTÉNIDE - Foi o ciúme, Cóclide, e uma paixão exagerada. Creio que Crócale tinha pedido dois talentos a Dinómaco, para que este a tivesse só para si. Ora, como Dinómaco não estivesse disposto a pagar essa quantia, ela pô-lo na rua, bateu-lhe com a porta na cara - é o que se diz - e recebeu um tal Gorgo de Énoe, rico lavrador e boa pessoa, que há muito estava apaixonado por ela. Então bebia com ele e contratou-me a mim para tocar flauta para os dois. Enquanto o beberete ia decorrendo, eu executava uma ária lídia ${ }^{74}$ o lavrador já se tinha levantado para dançar, e Crócale acompanhava com palmas ${ }^{75}$... enfim, tudo corria agradavelmente. Nisto, ouviu-se um estrondo e grande algazarra; a porta principal foi arrombada e, logo a seguir, irromperam por ali dentro oito robustos jovens, entre os quais o... «megarense». Puseram logo tudo de pantanas, e Gorgo, como já disse, foi espancado e jazia estendido no chão; Crócale, não sei lá como, precipitou-se em fuga para casa da sua vizinha Tespíada; e eu apanhei umas bofetadas de Dinómaco, que me atirou à cara

${ }^{72} \mathrm{O}$ texto diz «flautas»: trata-se da flauta dupla, donde, em gr., o plural.

73 Trata-se de um jarráo grande, denominado "cratera», onde se misturavam vinho e água, e de onde os convivas se serviam.

${ }^{74}$ Música dolente e sensual.

75 Melhor do que «bater as palmas», donde "aplaudir» (interpretação de alguns comentadores e tradutores), prefiro o sentido de «acompanhar o ritmo com palmas».. 
a flauta quebrada, gritando: "Desaparece daqui!». E agora vou já daqui contar o sucedido ao meu patrão, enquanto o lavrador vai ter com alguns amigos que tem na cidade, para entregar o «megarense» aos prítanes.

3] CÓCLIDE — É isto o que ganhamos em ter amantes soldados: espancamentos e processos em tribunal. Aliás, dizem-se generais e quiliarcas, mas, quando é preciso pagar, dizem: "Espera pelo pagamento do ordenado; logo que receba a soldada, dou-te tudo." Raios partam esses pantomineiros. Eu é que faço bem em não receber nem um sequer. Quem me dera um pescador, um marinheiro ou um lavrador da minha classe social, um que pouco saiba de lisonjas, mas que me traga muitos presentes. Esses outros, que agitam os penachos e narram as suas batalhas, ó Parténide, é tudo conversa fiada. 
DIÁLOGOS DOS DEUSES 
Texto da ed. de Karl Mras, Die Hauptwerke des Lukian 


\section{INTRODUÇẤO}

Embora muitas das obras de Luciano assumam a forma de diálogo, algumas receberam mesmo esse título: Diálogos dos Deuses, Diálogos dos Deuses Marinhos, Diálogos dos Mortos e Diálogos das Cortesás. Sob o aspecto de curtas cenas mais ou menos dramatizadas, Luciano critica a velha mitologia, as velhas e novas crendices, a moralidade de deuses e homens, a vida social do seu tempo, etc.

Especialmente nos Diálogos dos Deuses, Luciano refere-se a certos aspectos do comportamento dos deuses, que certamente mais escandalizariam as mentes mais instruídas. Podemos mesmo perguntar se, pelo menos no tempo de Luciano, os intelectuais e os filósofos acreditavam mesmo nos deuses e nos seus diversos e vergonhosos... currículos. Já muito antes do tempo de Luciano, surgem figuras que póem em causa toda essa mitologia, como, no tempo de Sócrates, um tal Diágoras de Melos; e até mesmo Sócrates não se livrou da acusação de não acreditar nos deuses em que a cidade acreditava.

Naturalmente, muitos filósofos, prosadores, poetas e outros intelectuais, encaravam a mitologia como elemento cultural que não deviam destruir, ou como uma preciosa herança inspiradora da arte e da literatura, que era preciso preservar. Mas, do mero ponto de vista da existência dos deuses e da realidade dos seus actos, poucos seriam os que verdadeiramente acreditavam. Diferente seria, porém, o caso das pessoas comuns, às quais geralmente não ocorrem questóes de simples lógica racional.

Veja-se, p. ex., o diálogo (Diálogo dos Mortos, 30) travado entre Minos, juiz dos infernos, e o malfeitor e assassino Sóstrato, que Minos sumariamente condena a ser lançado no Piriflegetonte (rio de fogo). Ora o condenado acha-se no direito de se defender, por muito que Minos entenda que ele não pode ter nada a alegar em sua defesa. É interessante o facto de o acusado não negar os seus crimes, mas a defesa vai ser feita segundo o método dialéctico. Diz Sóstrato que a condenação, simplesmente, não é justa. E porquê? Porque o acusado é — como hoje diríamos - inimputável, já que todos os seus actos foram involuntários, pelo simples facto, reconhecido por Minos, de todos esses actos terem sido tecidos pela Parca (Cloto), à qual nem os homens nem sequer os deuses podem opor-se. Por isso Sóstrato argumenta que, se uma pessoa é forçada a cometer 
um acto, sem ter capacidade de a ele se opor, o culpado será, única e simplesmente, aquele que deu uma tal ordem, e não o executor, o qual — reconhece Minos - tem tanta culpa como, por exemplo, uma espada que mata, mas sem vontade própria. Então Minos, reforçando ainda mais a razão do... sofista ("Poderás ver muitas outras coisas que ocorrem contra a lógica»), manda-o em paz, mas avisando: "Mas vê lá não ensines também os outros mortos a fazerem perguntas dessas."

Naturalmente, o argumentador não é Sóstrato, mas Luciano, que, deste modo, póe a nu a fragilidade da justiça divina.

Outros cenas dos Diálogos dos Deuses poderiam ilustrar o espírito crítico de Luciano. O leitor, à medida que for lendo cada diálogo, sentirá esse criticismo ao mesmo tempo risonho e corrosivo. Para os poetas e oradores, a mitologia constitui uma riquíssima fonte de inspiração, mas os filósofos e os historiadores devem distanciar-se do sentido literal dessas autênticas fábulas. Por exemplo: Zeus e as suas metamorfoses para fins clandestinos (Io, Ganimedes...) e os seus... partos incríveis: dá à luz Atena (pela cabeça) e Dioniso (pela coxa); os amores, ainda que infelizes, de Apolo com Jacinto e Dafne; a raiva e o ciúme, muito... humanos de Hera; Hermes, o menino ladrão e senhor de outras astúcias; o deus Hélio, o Sol, por ordem de Zeus, faz uma paragem no seu curso, de forma que a duração da noite triplique, para que Zeus possa passar uma tripla noite de amor com a esposa de Anfitrião; noutra ocasião, o mesmo Hélio entrega a condução do carro a seu filho Faetonte: resultado catastrófico; a deusa Selene, a Lua, também se atrasa no seu curso, para contemplar o seu bem-amado Endímion dormindo; as frechadas de Eros e outras traquinices nada inocentes; os novos deuses, Asclépio e Héracles, e a sua rivalidade fútil; os amores furtivos de Afrodite e Ares; o concurso de beleza entre Atena, Hera e Afrodite e os processos de influenciar (leia-se: subornar) o juiz, processos que, no caso de Afrodite, são verdadeiramente abjectos, não só para nós, modernos, mas também para Luciano e muitas pessoas sensatas, que não viam no comportamento dos deuses nada ou quase nada digno de imitação.

\section{OBSERVAÇÃO}

1. Seguimos a ordenação e a numeração de KARL MRAS, Die Hauptwerke des Lukian, Ernst Heimeran Verlag, Viena, 1954. A numeração da ed. Loeb (e outras ediçóes) vai entre parênteses rectos. 
2. No entanto, o texto de base é o da "Loeb Classical Library», com algumas modificaçóes,

3. Incluímos nos Diálogos dos Deuses o No 20 de Mras $(O$ Julgamento das Deusas), que a ed. Loeb remete para o vol. III. Neste diálogo, seguimos as liçôes de MRAS. 
(Página deixada propositadamente em branco) 
DIÁLOGOS DOS DEUSES 
(Página deixada propositadamente em branco) 


\section{Prometeu e Zeus [5]}

1] PROMETEU — Ó Zeus, solta-me, que já padeci horrivelmente.

ZEUS - O quê? Soltar-te, a ti, que devias ter grilhetas ainda mais pesadas, ter todo o Cáucaso sobre a tua cabeça e dezasseis abutres não só a dilacerar-te o fígado, mas também a arrancar-te os olhos, como castigo por nos teres modelado esses seres que são os homens, por nos teres roubado o fogo e teres criado mulheres? Será preciso mencionar também como me enganaste na distribuição da carne, servindo-me ossos disfarçados nas gorduras e guardando para ti a melhor das partes?

PROMETEU - Porventura não fui já suficientemente punido durante todo este tempo pregado no Cáucaso, alimentando com o meu fígado a pior das aves, esta maldita águia?

ZEUS - Isso não é nem sequer uma pequena parte do que mereces sofrer.

PROMETEU — Em todo o caso, ó Zeus, não será gratuitamente que me soltarás, pois [em troca] eu fornecer-te-ei uma informação muitíssimo importante.

2] ZEUS - Estás a querer iludir-me, Prometeu.

PROMETEU - E que é que eu ganharia com isso? De facto, nessa altura, tu não desconhecerias onde fica o Cáucaso nem terias falta de grilhóes, caso eu fosse apanhado a enganar-te.

ZEUS - Mas, antes de mais, diz-me cá que paga é essa assim tão importante que tu me darás.

PROMETEU - Se eu te disser para onde é que tu te encaminhas neste momento, acreditarás em mim e nas minhas restantes profecias?

ZEUS - Claro que sim.

PROMETEU - Vais a casa de Tétis, para teres relaçóes com ela.

ZEUS — Nisso acertaste; mas... e a seguir? Sim, parece-me que vais dizer uma coisa verdadeira.

PROMETEU - Ó Zeus, não tenhas relações com a Nereida, pois, se ela engravidar de ti, a criança far-te-á o mesmo que tu fizeste a... ${ }^{76}$

ZEUS - Queres tu dizer que serei expulso do meu reino?

PROMETEU - Oxalá que não, Zeus... mas uma relação com ela é uma ameaça algo parecida com isso.

\footnotetext{
${ }^{76}$... Cronos, deposto pelo filho. Prometeu não se atreve a dizer o nome.
} 
ZeUS - Nesse caso, digamos adeus a Tétis. Que Hefesto te solte por esta informação. 


\section{Eros E ZeUS [6]}

1] EROS - Ó Zeus, se eu pequei nalguma coisa, perdoa-me, pois ainda sou uma criança insensata.

ZEUS - Tu, Eros, uma criança... tu que és muito mais velho que Jápeto? Lá porque não tens barba nem cabelos brancos, já te julgas no direito de ser considerado um bebé... tu, que não passas de um velho e de um velhaco?

EROS - Então que grande mal é que eu te fiz, eu, um velho, segundo dizes, para pensares em me pôr a ferros.

ZEUS - Vê lá bem, meu tratante, se é coisa de pouca monta teres feito pouco de mim, a ponto de não haver figura por que não me tenhas feito passar: sátiro, touro, [chuva de] ouro, cisne, águia... Ora, tu nunca por nunca fizeste que uma mulher se apaixonasse [espontaneamente] por mim, nem nunca me apercebi de, graças a ti, ter sido agradável a uma mulher, mas, pelo contrário, tive de servir-me de artes mágicas e disfarçar-me. Elas gostam muito de um touro ou de um cisne, mas, se me vissem [como eu sou], morreriam de medo.

2] EROS - É natural, ó Zeus, pois elas, mortais como são, náo suportam o teu aspecto.

ZEUS - Então porque é que Branco e Jacinto amam Apolo?

EROS - E no entanto, Dafne fugia de Apolo, apesar de ele ter uma [bela] cabeleira e ser imberbe. Ora, se queres ser amado, não agites a égide nem empunhes o raio, mas mostra-te o mais simpático possível e terno só de se ver; usa cabeleira encaracolada, presos ao alto com uma mitra, veste um manto de púrpura, [calça] umas sandálias de ouro, caminha ritmicamente ao som da flauta e de pandeiros, e verás que vão atrás de ti em número maior que as Ménades de Dioniso.

ZEUS - Vai-te daqui! Não admitiria ser amado à custa de me apresentar desta forma.

EROS - Nesse caso, ó Zeus, não queiras amar: é mais fácil assim.

ZEUS - Oh não! [Eu quero] amar, sim, mas também conseguir chegar junto delas sem problemas. Por estes dois favores, deixo-te ir em paz. 
(Página deixada propositadamente em branco) 


\section{ZeUS E HeRmeS [7]}

ZEUS - Ó Hermes, conheces a formosa filha de Ínaco?

HERMES - Sim; referes-te a Io?

ZEUS - Já não é uma moça, mas uma bezerra.

HERMES - Que monstruosidade! Como é que se transformou?

ZEUS - Foi Hera, que, por ciúmes, a metamorfoseou. E concebeu ainda contra a desgraçada uma coisa inaudita e terrível: pôs a guardá-la um certo pastor de muitos olhos, de nome Argos, que apascenta a bezerra sem nunca adormecer.

HERMES - E então que é que eu devo fazer?

ZEUS - Voa até Nemeia - que é nessa região que Argos pastoreia —, mata-o, leva Io por cima do mar até ao Egipto e transforma-a em Ísis; daí em diante, será uma deusa para os desse país, fará refluir as águas do Nilo, enviará os ventos e salvará os navegantes. 
(Página deixada propositadamente em branco) 


\section{Zeus E Ganimedes [10]}

1] ZEUS - Vamos lá, Ganimedes: agora que chegámos ao nosso destino, dá-me já um beijo, para que verifiques que já não tenho um bico adunco, nem garras afiadas, nem asas, na forma em que te apareci, disfarçado de ave.

GANIMEDES — Ó homem! Então há pouco não eras uma águia que me raptou do meio do meu rebanho e me trouxe voando até aqui? Como é que essas tuas asas desapareceram, e agora te mostras completamente diferente?

ZEUS - Meu jovenzinho, tu não estás a olhar nem para um homem, nem para uma águia, pois, aqui onde me vês, sou o rei de todos os deuses: só momentaneamente mudei de figura.

GANIMEDES - É o quê? Tu és o famoso Pã? Então porque é que não trazes a flauta, nem tens cornos, nem as pernas peludas?

ZEUS - Julgas que esse [Pã] é o único deus?

GANIMEDES - Sim, e até lhe sacrificamos um bode não castrado, que levamos à gruta onde ele está. Mas... tu pareces mais um traficante de escravos.

2] ZEUS - Diz-me cá: nunca ouviste [pronunciar] o nome de Zeus, nem viste o seu altar no Gárgaro, desse Zeus que chove, troveja e produz o raio?

GANIMEDES - Então, meu caro, estás a dizer que és aquele que outro dia atirou para cima de nós uma forte granizada, aquele que, segundo dizem, habita lá em cima, aquele que grande estrondo, a quem meu pai sacrificou um carneiro? Ora, que mal te fiz eu, ó rei dos deuses, para me teres raptado? Neste momento, talvez os lobos tenham caído sobre as minhas ovelhas desprotegidas e estejam a despedaçá-las.

ZEUS - Ainda estás preocupado com as ovelhas, tu, que foste feito imortal e vais coabitar aqui connosco?

GANIMEDES - É o quê? Então não tencionas levar-me ainda hoje para o [monte] Ida?

ZEUS - De maneira nenhuma, pois teria sido em vão que eu me transformei de deus em águia.

GANIMEDES - Mas o meu pai há-de procurar-me e ficará zangado por náo me encontrar, e eu levarei pancada por ter abandonado o rebanho.

ZEUS - E onde é que ele te encontrará? 
GANIMEDES - Isso nunca, pois tenho saudades dele. Mas, se me levares de volta, prometo-te que te será sacrificado outro carneiro do seu rebanho como paga da minha libertação. Temos aquele de três anos, o grande, que conduz [o rebanho] para a pastagem.

3] ZEUS - Como é ingénuo este menino, como é simplório... sim, é isso mesmo: é ainda um menino... Em todo o caso, Ganimedes, diz adeus a todas essas coisas e esquece-te delas: do teu rebanho e do Ida. Ora tu, que agora já és um ser celestial, podes, daqui, fazer bem ao teu pai e à tua pátria e, em vez de queijo e leite, comerás ambrósia e beberás néctar; apenas terás de servir esta bebida a todos nós; e, ainda mais importante, já não serás homem, mas sim imortal; e farei que a tua estrela seja a mais brilhante... enfim, serás completamente venturoso.

GANIMEDES - E... se eu quiser brincar, quem brincará comigo? Sim, que no Ida éramos muitos da mesma idade.

ZEUS - Tens cá, para brincar contigo, aqui o Eros, e muitos ossinhos para jogares. Vá lá, anima-te, mostra-te alegre e não anseies pelas coisas lá de baixo.

4] GANIMEDES - Mas em que é que eu vos seria útil? Haverá por cá necessidade de um pastor?

ZEUS - Não, mas serás o nosso escanção, terás a teu cargo o néctar e supervisionarás o banquete.

GANIMEDES - Isso não me é penoso, pois sei como se deve verter o leite e colocar a vasilha.

ZEUS - Vejam lá como ele se lembra outra vez do leite e julga que está a servir homens. Isto aqui é o céu e, como eu disse, bebemos néctar.

GANIMEDES - Mas, ó Zeus, isso é mais agradável que o leite?

ZEUS - Em breve o saberás e, depois de provares, nunca mais terás saudade de leite.

GANIMEDES - E onde é que eu dormirei de noite? Com o meu companheiro Eros?

ZEUS - Não, pois eu raptei-te com a intenção de dormirmos juntos.

GANIMEDES - Não poderias dormir sozinho? Será mais agradável dormir comigo?

ZEUS - Sim, pelo menos com um rapaz tão formoso como tu, Ganimedes. 
5] GANIMEDES - Em que é que a minha formosura te fará bem em termos de sono?

ZEUS - Ela possui um doce encanto, que torna o sono mais suave.

GANIMEDES - Mas o meu pai zangava-se comigo, quando eu dormia com ele, e dizia, logo de manhã, que eu o tinha impedido de dormir, revolvendo-me na cama, dando-lhe pontapés e falando enquanto dormia, de tal modo, que, a maior parte das vezes, me mandava dormir junto de minha mãe. Portanto, se, como dizes, foi para isso [para dormir contigo] que me raptaste, estás a tempo de me pôr de novo na terra, ou terás problemas de insónia, pois eu incomodar-te-ei revolvendo-me continuamente [na cama].

ZEUS - Isso mesmo é a coisa mais agradável que tu me farás: ficar acordado ao teu lado, beijando-te mil vezes e abraçando-te.

GANIMEDES - Tu próprio verás: eu dormirei, enquanto tu me dás beijinhos.

ZEUS - Nessa altura veremos o que fazer; mas por agora, ó Hermes, leva-o e, depois de ele beber um trago de imortalidade, trá-lo para nos servir de escanção, mas primeiro ensina-o como deve servir a taça. 
(Página deixada propositadamente em branco) 


\section{Hera e Zeus [8]}

1] Hera - Ó Zeus, desde que raptaste este jovenzinho frígio e o trouxeste do monte Ida, dás-me muito menos atenção.

ZEUS - Ó Hera, então já estás com ciúmes dele, tão simples e tăo inocente? Eu pensava que tu eras dura apenas para as mulheres que tivessem relaçóes comigo.

2] Hera - Não procedes bem nem é decoroso para ti que, sendo senhor de todos os deuses, me deixes aqui, a mim, tua legítima esposa, e desças à terra para cometer adultérios, disfarçado de [chuva de] ouro, de sátiro, de touro... com a diferença de que essas mulheres ficam na terra, ao passo que a este jovem lá do [monte] Ida, tu, o mais nobre de entre... as águias, raptaste-o, voaste com ele até cá para cima, e agora convive aqui connosco, impingido assim sem o meu consentimento, para, supostamente, ser teu escanção. Precisas assim tanto de escançôes? Ou será que Hebe e Hefesto se fartaram de ser teus criados? Ora, tu náo recebes o a taça das mãos deste [jovem] sem antes o beijares à vista de toda a gente... um beijo que é, para ti, mais doce que o néctar, e por isso é que, mesmo sem teres sede, estás sempre a pedir mais uma taça; algumas vezes, provas só um pouquito, e devolves-lhe a taça; e, depois de ele ter bebido, pegas na sua taça e bebes o que fica no fundo, pelo bordo por onde o jovem tinha bebido e onde tinha tocado com os lábios, de modo que bebes e beijas ao mesmo tempo. Aqui há dias, o rei e pai de todos, tendo poisado a égide e o raio, sentou-se a jogar aos ossinhos com ele... com uma barba desse tamanho todo... Sim, eu vi tudo isso, não julgues que me passou despercebido.

3] ZEUS - E que mal tem, ó Hera, que eu, ao mesmo tempo que bebo, beije e me console com ambas as coisas, com o beijo e com o néctar? Se eu permitir que ele te beije nem que seja uma só vez, deixarás de me censurar por considerar que o beijo é preferível ao néctar.

HERA - Isso são palavras de pederastas. Oxalá nunca fique táo louca, que aproxime os meus lábios desse delicado frígio, tấo efeminado.

ZEUS - Ó nobre [Senhora], não me censures pelo meu queridinho: este efeminado, este bárbaro, este delicadinho é 
para mim mais deleitoso e mais desejável que... - Não, não quero dizer, para não te exasperar ainda mais.

4] HERA - Cá por mim, até podes casar com ele; mas lembra-te dos insultos avinhados que me lançaste por causa desse escanção.

ZEUS — Pois não... [Se calhar] era melhor ser Hefesto, o teu filho coxo, a servir-nos o vinho, ao chegar da forja, ainda sujo de escumalha, acabado de poisar a tenaz, e recebermos a taça daqueles seus dedos, puxá-lo para nós e beijá-lo... Nem mesmo tu, sua mãe, terias gosto em beijá-lo, assim com o rosto todo negro de fuligem. Ai náo? Quer dizer que Hefesto seria o escanção mais adequado ao simpósio dos deuses, e Ganimedes devia ser recambiado para o [monte] Ida? Na verdade, este é muito asseado, tem dedos rosados, sabe como se oferece a taça e - é isso que mais te aflige — os seus beijos sáo mais doces que o néctar.

5] HERA - Ó Zeus, então só agora, desde que o monte Ida gerou este belo jovem de longa cabeleira, é que Hefesto é coxo, é que os seus dedos são indignos da tua taça, está coberto de fuligem e ficas com náuseas só de vê-lo, mas dantes não vias nada disso, e a escumalha e a forja não te impediam de tomar a bebida da sua máo.

ZEUS - Ó Hera, com esses teus ciúmes, não fazes mais que afligir-te a ti e aumentar a minha paixão. Se te desgosta receber a taça das máos deste formoso jovem, que o teu filho te sirva de escanção... E tu, Ganimedes, serve-me a taça só a mim e, de cada uma, beija-me duas vezes: sempre que ma servires cheia, e depois outra vez quando ta devolver. Mas... que é isso? Estás a chorar? Não tenhas medo: se alguém pretender afligir-te, lamentar-se-á [amargamente]. 


\section{Hera e Zeus [9]}

1] HERA - Ó Zeus, que opinião tens tu a respeito desse tal Ixíon?

ZEUS - É boa pessoa, Hera, e bom companheiro de bebida... aliás, não acompanharia connosco, se fosse indigno da nossa mesa.

HERA - Pois é mesmo indigno, esse insolente. Por isso, nunca mais o convides.

ZEUS - Que insolência é que ele cometeu? Sim, preciso de saber.

HERA - Claro que sim... mas... envergonho-me de dizer, tão grande foi o seu descaramento.

ZEUS - Se ele cometeu uma acção assim tão vergonhosa, maior razão para me contares. Acaso terá ele tentado seduzir qualquer pessoa? Imagino o género de acto vergonhoso, para que tu hesites em contar.

2] HERA - Foi a mim, ó Zeus, e não a qualquer pessoa [que ele tentou seduzir]... e já desde há bastante tempo. Ao princípio, náo percebia a coisa, quando ele olhava para mim muito fixamente; suspirava e lacrimejava; e, sempre que eu, depois de beber, entregava a taça a Ganimedes, ele pedia-lhe que lhe desse de beber por essa mesma taça; pegava nela, beijava-a, e, a meio [da bebida], aproximava-a dos olhos e voltava a olhar para mim. Nesse momento, compreendi que eram sinais de amor. Durante muito tempo, tive vergonha de te contar, além de que julgava que o homem havia de pôr termo a essa loucura; Quando, porém, se atreveu a declarar-se por palavras, eu deixei-o ainda a chorar e a rebolar-se pelo chão, tapei os ouvidos para não o ouvir suplicar coisas insolentes e vim contar-te. Agora, trata tu mesmo de punir o indivíduo.

3] ZEUS - Que grande tratante, [querendo] passar por cima de mim e [chegar] até ao amor de Hera. Estaria ele assim tão embriagado de néctar? Mas nós é que temos a culpa disto, por sermos demasiado amigos dos homens e por tê-los feito nossos convivas nos banquetes. Portanto, eles até têm desculpa, se, bebendo o mesmo que nós e vendo as beldades celestes e todas as outras coisas que nunca tinham visto na terra, desejaram gozar de tudo isso, tocados pelo amor; sim, que o amor é uma 
força violenta, que domina não só os homens, mas também, algumas vezes, nós próprios, [os deuses].

HerA - Pelo menos de ti, Amor é senhor absoluto, que, segundo se diz, te traz preso e te arrasta pelo nariz; e tu segue-lo para onde quer que ele te conduza, transformas-te facilmente naquilo que ele ordena... numa palavra, és sua propriedade e seu joguete. E agora estou a ver que lhe concedes perdáo, atendendo a que tu próprio tiveste relaçóes adúlteras com a mulher dele, que te deu à luz Pirítoo.

4] ZEUS - Continuas a evocar todas as vezes que eu fui à terra para me divertir? Sabes o que entendo fazer com Ixíon? Castigá-lo ou expulsá-lo da nossa mesa... de modo nenhum, pois seria falta de educação. Mas, uma vez que ele está apaixonado e, segundo dizes, chora e sofre tormentos insuportáveis...

HERA - O quê? Ó Zeus! Receio que também tu vás dizer algo ultrajante.

ZEUS - De modo nenhum, mas antes, modelemos, com uma nuvem, uma imagem igual a ti; e, quando o banquete terminar e ele, como é natural, não consiga dormir por causa da paixão, nós levamos a imagem e colocamo-la reclinada sobre ele; assim, ele deixaria de se atormentar, julgando que tinha conseguido o que almejava.

HERA - Raios partam o homem, mais os seus desejos acima do que é possível.

ZEUS - Espera um pouco, Hera. Sim, que mal te poderia vir da tua imagem, se, afinal, Ixíon tiver relações com uma nuvem?

5] HERA - Mas a nuvem parecer-se-á comigo, e então a vergonha recairá sobre mim, devido à parecença.

ZEUS — Nada disso, pois nem a nuvem se transformará alguma vez em Hera, nem tu em nuvem. Só Ixíon é que será enganado.

HERA - Mas os homens são todos uns ignorantes, e ele, ao descer à terra, talvez se gabe e conte a toda a gente que tem tido relaçôes com Hera, que compartilha o leito com Zeus e, enfim, afirmará que eu o amo; e os homens acreditarão, sem saberem que ele teve relaçóes com uma nuvem.

ZEUS - Pois bem, se ele disser uma coisa dessas, precipitá-lo-ei no Hades, amarrá-lo-ei a uma roda, juntamente com a qual o desgraçado girará continuamente e sentirá um sofrimento sem fim, como punição, não da sua paixão amorosa (pois isso não tem nada de mal), mas da sua exagerada fanfarronice. 


\section{Hefesto e Apolo [11]}

1] Hefesto - Já viste, ó Apolo, o bebé recém-nascido de Maia, como é formoso e ri para toda a gente, e como revela já que será uma grande personagem?

APOLO - Ó Hefesto! Uma grande personagem, aquele bebé, que é mais velho que Jápeto no que toca a velhacaria?

HEFESTO - Mas que mal poderia ele ter feito, assim acabado de nascer?

APOLO - Pergunta a Posídon, a quem ele roubou o tridente, ou a Ares, cuja espada, sem ele dar por isso, lhe tirou da bainha... isto para não falar de mim próprio, a quem ele desarmou do arco e das flechas.

2] HefESTO - Este recém-nascido, envolto em fraldas, que mal se tem nas pernas?

APOLO - Ficarás a saber, ó Hefesto, caso ele chegue perto de ti.

HEFESTO - E é que já chegou mesmo.

APOLO - E entáo? Tens todas as ferramentas, sem faltar nenhuma?

HEFESTO - Todas, Apolo.

APOLO - Em todo o caso, repara bem.

HEFESTO - Por Zeus! Não vejo a tenaz.

APOLO - Mas vê-la-ás nas fraldas do bebé.

HEFESTO - Terá uma mão assim tão ágil, como se tivesse praticado no ventre da mãe?

3] APOLO - E ainda tu não o ouviste falar: é cá um palavreado, uma fluência... Além disso, quer já servir-nos [como mensageiro]. Ontem mesmo, tendo desafiado Eros [para uma luta], venceu-o num instante, atirando-o ao chão, não sei lá como, com um golpe de pés; depois, no momento em que estava a ser felicitado, roubou a cinta a Afrodite, enquanto esta o abraçava pela vitória; e, ainda Zeus estava a rir com este caso, roubou-lhe o ceptro; e, se o raio náo fosse tão pesado e não tivesse tanto fogo, também o roubaria.

HEFESTO - Pelo que me contas, trata-se de uma criança sobredotada.

APOLO - E não é tudo, pois ele já é um [grande] músico. HEFESTO - Como podes provar isso? 
4] APOLO - Tendo achado uma tartaruga morta, construiu com ela um instrumento musical: acrescentou-lhe um braço, fixou-lhe uma travessa, depois meteu-lhe cavilhas, pôs-lhe um cavalete e, com sete cordas esticadas, toca com muitíssima graça e harmonia, de tal modo que eu próprio, que há muito pratico a lira, fico cheio de inveja. Dizia-me Maia que ele não permanece de noite no céu, mas que, por curiosidade, desce até ao Hades... para de lá roubar qualquer coisa, é claro. Ele até possui asas nos pés e mandou fazer um caduceu com um poder maravilhoso, com o qual conduz as almas e leva os mortos lá para baixo.

HEFESTO - Fui eu que lho dei, para ele brincar.

APOLO - E ele pagou os teus honorários, foi-te à tenaz e...

HEFESTO - Fizeste bem em me lembrar: vou já buscá-la... se é que, como tu dizes, ela se encontra no meio das fraldas. 


\section{Hefesto e Zeus [13]}

1] Hefesto - Ó Zeus, que é que queres que eu faça? Pois aqui estou, como me ordenaste, com o machado muito bem afiado, capaz de cortar uma pedra ${ }^{77}$ de meio a meio de um só golpe.

ZEUS - Muito bem, Hefesto. Pois então racha-me a cabeça com um golpe de alto a baixo.

HEFESTO - Estás a experimentar-me, a ver se eu estou louco? Manda-me mas é fazer o que realmente queres que eu faça.

ZEUS - Isso mesmo: que me raches o crânio. Se não me obedeceres, não será a primeira vez que experimentarás a minha fúria. Mas deves bater-me com toda a alma e sem tardar, pois estou aflito de morte, com dores de parto que me transtornam a cabeça.

HEFESTO - Vê lá bem, Zeus, não te cause algum mal, pois o machado está muito afiado e náo executará o parto sem dor nem à maneira de Ilitia.

ZEUS - Vamos, Hefesto, chega-lhe de alto a baixo, com alma! Eu é que sei o que é do meu interesse.

HEFESTO - [Contra a minha vontade ${ }^{78}$, mas vou mesmo chegar-lhe. Sim, que poderei fazer contra as tuas ordens? Mas... que é isto? Uma jovem armada? Ó Zeus, tinhas um grande mal na cabeça. É natural que andasses de mau humor, gerando sob a membrana do cérebro uma jovem desse tamanho todo, viva e ainda por cima armada. Sem nós nos apercebermos, o que tu tinhas era um campo de batalha, não uma cabeça... E agora ela salta, executa a dança pírrica, agita o escudo, brande a lança e está possuída de entusiasmo divino e - o mais maravilhoso de tudo - tornou-se, em muito pouco tempo, muitíssimo bela e vigorosa; é certo que tem os olhos cinzentos, mas o elmo disfarça este defeito. Portanto, ó Zeus, como pagamento ao parteiro, promete-ma já em casamento.

ZEUS - Ó Hefesto, pedes-me uma coisa impossível, pois ela vai querer ser virgem para sempre. Cá por mim, não tenho nada a opor.

HEFESTO - É o que eu queria ouvir. Deixa o resto comigo, que vou já levá-la.

\footnotetext{
77 Sigo a lição do ms. L (da família $\beta$ )

78 Segundo a lição de alguns mss.
} 
ZEUS - Se achas melhor, procede desse modo, mas eu sei que pretendes o impossível. 


\section{Posídon e Hermes [12]}

1] POSíDON - Ó Hermes, será que posso encontrar-me com Zeus?

HERMES - De modo nenhum, Posídon.

POSÍDON - Mesmo assim, anuncia-me a ele.

HERMES - Não me incomodes, já disse; é inoportuno, por isso não podes visitá-lo neste momento.

POSÍDON - Porventura ele está com Hera?

HERMES - Não, é uma coisa diferente.

POSÍDON - Compreendo: Ganimedes está lá dentro.

HERMES - Também não. Está adoentado.

POsíDON - Que é que ele tem, ó Hermes? É espantoso o que me estás a dizer.

HERMES - Tenho vergonha de dizer, mas é como te digo.

POSÍDON - Mas não deves ter vergonha comigo, que sou teu tio.

HERMES - Bem, Posídon... ele acaba de dar à luz.

POSÍDON - C' um raio, acaba de dar à luz? Por obra de quem? Será que tem andado a ocultar-nos que é andrógino? Mas... o seu ventre náo denotava qual inchaço...

HERMES - Dizes bem, mas não era no ventre que ele tinha o feto.

POSÍDON — Já sei: deu à luz outra vez pela cabeça, como no caso de Atena. Realmente, tem uma cabeça parideira.

HERMES - Nada disso, mas trazia na coxa o menino de Sémele.

POSÍDON - Que sujeito magnífico, que fica grávido por todas as partes do corpo. Mas quem é essa Sémele?

2] Hermes - É tebana, uma das filhas de Cadmo. Teve relaçóes com ela e engravidou-a.

POSÍDON - E depois, ó Hermes, foi ele que deu à luz, em vez de ser ela?!

HERMES - Justamente, por muito estranho que isso te pareça. $\mathrm{Na}$ verdade, Hera — tu bem sabes como ela é ciumenta - foi ter com Sémele e persuadiu-a a pedir a Zeus que viesse a sua casa, mas trazendo consigo os trovóes e os relâmpagos. E Zeus deixou-se convencer e chegou trazendo também o raio, pelo que o telhado se incendiou e Sémele morreu no incêndio. Então Zeus ordenou-me que fizesse uma incisão no ventre da mulher e dele retirasse o feto ainda incompleto, apenas com sete meses. Assim 
fiz, e ele, tendo feito uma abertura na coxa, introduziu o feto, para que aí chegasse ao termo [da gravidez]. E agora, a caminho do terceiro mês, deu à luz e encontra-se adoentado de dores de [pós-]parto.

POSÍDON - E onde se encontra neste momento o bebé?

HERMES - Levei-o a Nisa e entreguei-o às Ninfas, para que o criassem, com o nome de Dioniso.

POSíDON - Quer dizer que o meu irmão Zeus é ao mesmo tempo mãe e pai desse tal Dioniso?!

HeRMeS - Parece que sim. Bem... vou dar-lhe água para [lavar] a ferida e fazer outras coisas julgadas necessárias, como se fosse para uma parturiente. 


\section{Hermes e Hélio [14]}

1] HERMES - Ó Hélio, por ordem de Zeus, não conduzas hoje o teu carro, nem amanhã, nem depois de amanhã, mas fica em casa, e que entretanto haja uma só noite muito longa. Portanto, que as Horas desatrelem os cavalos, e tu apaga o fogo e descansa durante este longo tempo.

HÉLIO - Ó Hermes, o que tu vieste anunciar-me é uma coisa inaudita e muito estranha. Parece-te que eu me terei desviado da minha rota e guiado [o carro] fora das baias, e que por isso ele está furioso comigo e resolveu fazer a noite três vezes mais longa que o dia?

HERMES - Nada disso, nem é coisa para sempre, mas só por agora é que ele necessita de uma noite mais longa.

HÉLIO - E onde é que ele se encontra? Donde é que te enviou a anunciares-me essa ordem?

HERMES — Da Beócia, ó Hélio, de junto da esposa de Anfitrião, por quem está apaixonado e com quem agora se encontra.

HÉLIO - Mas não lhe basta uma noite?

HERMES - De maneira nenhuma, pois é preciso que dessa relação seja gerado um deus enorme e façanhoso ${ }^{79}$. Ora, isso torna-se impossível [de conseguir] num só dia.

2] HÉLIO — Pois então que ele meta mãos à obra e... boa sorte. Mas essas acçóes, ó Hermes (agora que ninguém nos ouve), não aconteciam no reinado de Cronos: este nunca dormia fora do leito de Reia nem deixaria o céu para ir dormir a Tebas, mas o dia era o dia, e a noite durava segundo a sua medida, de acordo com as estaçóes; não acontecia nada de estranho ou de anormal, e o deus não teria nunca tido relaçóes com uma mulher mortal. Agora, porém, por causa de miserável mulherzinha, há que alterar tudo por completo: os meus cavalos são obrigados a ficar presos de movimentos devido à inactividade; e o caminho, sem ser pisado durante três dias, ficará intransitável; e os pobres homens viverão nas trevas. É isso que eles ganharão com os amores de Zeus, esperando sentados e envolvidos em longa escuridão, até que ele acabe de fabricar o tal atleta de que tu falas.

HERMES - Cala-te, Hélio, ainda assim não te venha algum mal das tuas palavras. Bem, vou ter com Selene ${ }^{80}$ e com Hipno,

\footnotetext{
${ }^{79}$ Seguimos a lição dos mss. B e L (ed. K. Mras).

${ }^{80}$ Selene ou Selene, a Lua; Hipno, o Sono.
} 
a fim de lhes anunciar também a eles as ordens de Zeus: a uma, Selene, que avance muito lentamente, e ao Sono que não largue ${ }^{81}$ os homens, de modo que eles não saibam que a noite foi assim tão longa.

${ }^{81}$ Sigo a lição do ms. $\beta$ (e ed. de K. Mras). 


\section{Afrodite e Selene [19]}

1] AFRODITE - Ó Selene, que é isto que dizem de ti?... Que, sempre que te encontras sobre a Cária, fazes parar a parelha de cavalos e ficas a contemplar Endímion a dormir ao relento, como um caçador, e que algumas vezes, a meio da tua rota, chegas a descer até junto dele?!

SELENE - Ó Afrodite, pergunta ao teu filho ${ }^{82}$, pois é ele o culpado disto.

AFRODITE - Nem me fales! Esse [menino] é muito insolente... Quantas maldades ele me tem feito, a mim, sua própria mãe, quer fazendo-me descer o monte Ida por causa do troiano [Anquises], quer fazendo-me ir ao Líbano atrás desse jovem assírio [Adónis], a quem depois fez que fosse desejado também por Perséfone, e assim me roubou metade do meu querido ${ }^{83}$. Eu até já muitas vezes o ameacei de lhe quebrar as setas e a aljava e de lhe arrancar as asas, se ele não se deixasse dessas maldades. Também já lhe apliquei umas nalgadas com a sandália, mas ele, estranhamente temeroso e suplicante nesse momento, não tardava a esquecer-se do castigo...

2] ... Mas... diz-me cá: Esse teu Endímion é formoso? Nesse caso, a tua situação é inconsolável.

SELENE - Aos meus olhos, Afrodite, é mesmo muito formoso, especialmente quando está a dormir sobre uma rocha, coberto com a clâmide, tendo na máo esquerda as setas prestes a escorregar-lhe da mão, enquanto a mão direita, mais acima e dobrada à volta da cabeça, enquadra graciosamente o seu rosto, e ele, dormindo a sono solto, exala aquele seu hálito a cheirar a ambrósia. Então eu desço silenciosamente, avançando nas pontas dos pés, com receio de o acordar e o sobressaltar... Sabes como é... Para quê contar-te o resto, a náo ser que morro de paixáo por ele?

${ }^{82}$ Eros, Amor (o Cupido latino).

${ }^{83}$ Segundo a lenda, Adónis repartia a sua vida amorosa entre a deusa celeste (Afrodite) e a deusa infernal ) Perséfone). 
(Página deixada propositadamente em branco) 


\section{Afrodite E Eros [20]}

1] AFrodite - Ó Eros, meu filho, vê lá o que andas a fazer. Já não falo do que se passa na terra, dos actos que tu obrigas os homens a cometer, quer contra si mesmos, quer uns contra os outros, mas sim do que se passa no céu: mostras-nos Zeus sob muitas formas, transformando-o naquilo que de momento te parece, fazes Selene descer do céu, algumas vezes obrigas Hélio a atrasar-se em companhia de Clímene, esquecendo-se dos cavalos... para já não falar dos ultrajes que, com toda a desfaçatez, cometes contra mim, tua mãe. Mas tu, meu grande desavergonhado, até induziste Reia, já velha e mãe de tantos deuses, a apaixonar-se por jovens e desejar esse moço frígio, e agora, enlouquecida por ti, atrelou os seus leôes e, juntamente com os Coribantes arrebanhados, que são tão loucos como ela, percorrem o Ida, [monte] acima, [monte abaixo], ela ululando por Átis, e, dos Coribantes, um retalha os braços com uma espada, outro, soltando a cabeleira, corre furioso pelos montes, outro faz soar o corno, outro rufa no tambor, toca címbalo... enfim, é tudo algazarra e loucura no monte Ida. Por isso, temo tudo, mas temo sobretudo, eu que dei à luz uma grande peste, que Reia, num acesso de loucura, ou melhor, que, entrando em si, ordene aos Coribantes que peguem em ti e te despedacem, ou que te lancem aos leóes. É isso que eu temo, ao ver-te correndo um tal perigo.

2] EROS — Anima-te, mãe, pois já estou habituado [a lidar] com leões: salto-lhes muitas vezes para o lombo e conduzo-os, agarrando-lhes a crina como se fossem rédeas; e eles abanam [alegremente] a cauda, deixam-me meter-lhes a mão na boca e, depois de a lamberem, deixam-me retirá-la. E quanto a Reia, quando é que ela teria vagar para me castigar, toda ocupada como está com o seu Átis?! Em boa verdade, que mal vos faço eu, ao mostrar-vos como é a beleza? E vós mesmas, [divindades,] não gostais do que é belo? Portanto, não me censureis por isso. Ou será que tu própria, minha mãe, desistes de amar Ares e ser amada por ele?

AFrodite - Como tu és fino e sabes como dominar tudo! Em todo o caso, lembra-te, de vez em quando, das minhas palavras. 
(Página deixada propositadamente em branco) 


\section{ZEUS, ASCLÉPIO E HÉRACLES [15]}

1] ZEUS - Vocês aí, Asclépio e Héracles, deixem de discutir um com o outro, que até parecem humanos. Sim, essas discussões são indecorosas e indignas do simpósio dos deuses.

HÉRACLES - Ó Zeus, tu admites que este... curandeiro ocupe um lugar à mesa acima do meu?

ASCLÉPIO - Sim, por Zeus, pois sou superior a ti.

HÉRACLES - Em quê, meu... miolos-queimados? Será porque Zeus te atingiu com o seu raio, por fazeres o que não era lícito, ainda que agora, por ele ter dó de ti, compartilhes da nossa imortalidade?

ASCLÉPIO - Esqueces-te, Héracles, de que também tu foste queimado lá no [monte] Eta, para agora me censurares ter sofrido o fogo?

HÉRACLES - Mas as nossas vidas não foram as mesmas nem sequer idênticas: eu sou filho de Zeus, fartei-me de trabalhar para limpar o mundo, lutando contra monstros e punindo pessoas violentas, ao passo que tu não passas de um ervanário e de um charlatão, talvez útil aos pobres homens pela administração de remédios, mas sem teres cometido qualquer acto heróico.

2] ASCLÉPIO - O que tu não dizes é que te curei das queimaduras, quando ainda há pouco apareceste cá em cima semiqueimado e com o corpo em muito mau estado, devido a duas coisas: a túnica [mágica: de sua esposa Dejanira] e, depois disso, o fogo [da pira], enquanto eu, se mais não fosse, nem fui escravo como tu, nem cardei lã na Lídia, vestido de púrpura e apanhando pancada de Ônfale com uma sandália de ouro, nem matei os meus filhos e a minha esposa num acesso de fúria.

HÉRACLES - Se não páras de me insultar, ficarás em breve a saber que de nada te valerá a imortalidade, pois pego em ti atiro-te de cabeça para fora do céu, de modo que nem Péan te curará do esmagamento craniano.

ZEUS - Parai lá com isso e não nos estragueis a festa, ou terei de vos expulsar da sala. Em todo o caso, Héracles, é justo que Asclépio se sente em lugar superior ao teu, uma vez que morreu primeiro que [tu]. 
(Página deixada propositadamente em branco) 


\section{HeRMes e APOLO [16]}

1] HERMES - Ó Apolo, porque estás assim cabisbaixo? APOLO - É que, ó Hermes, ando com pouca sorte no amor. HERMES - Boa razão para estar triste. Mas... pouca sorte porquê? Será que o caso de Dafne ainda te aflige?

APOLO - De modo nenhum... É que estou de luto por aquele querido Lacónico, filho de Ébalo.

HERMES - Diz-me, foi Jacinto que morreu?

APOLO - Exactamente.

HERMES - E... ó Apolo, quem é que o matou? Houve alguém tão execrável, que seja capaz de matar esse formoso jovem?

APOLO - Foi obra própria minha.

HERMES - Nesse caso, estavas louco, ó Apolo.

APOLO - Nada disso, foi um acidente involuntário.

HERMES - Como? Quero ouvir como isso aconteceu.

2] APOLO - Ele estava a aprender a lançar o disco, e eu lançava o disco com ele, quando o mais ruim dos ventos, esse maldito Zéfiro, que desde há muito também estava apaixonado pelo jovem, mas era por ele rejeitado, não suportando o desdém, fez esse trabalho. Eu lancei o disco nos ares, como costumava, mas Zéfiro, soprando dos lados do Táigeto, impeliu o disco de maneira que fosse bater na cabeça do jovem, e de tal modo, que da ferida começou a correr muito sangue e o jovem morreu logo ali. Mas eu vinguei-me imediatamente de Zéfiro, atirando-lhe frechadas e perseguindo-o na sua fuga até à montanha; e quanto ao jovem, erigi-lhe um túmulo em Amiclas, no local onde o disco o atingiu; e fiz que do seu sangue a terra fizesse brotar uma flor mui deleitável, a mais garrida, ó Hermes, de todas as flores, uma flor que tem [nas suas pétalas] as letras da interjeição dedicada ao defunto ${ }^{84}$. Então, ainda te parece que eu estou triste sem motivo?

HERMES - Sim, Apolo, pois já sabias que te tinhas apaixonado por um mortal; por isso, não te aflijas por ele ter morrido.

${ }^{84} \mathrm{Nas}$ pétalas do jacinto, os antigos viam as letras AIAI (interj. $\alpha \hat{\imath} \alpha \hat{\imath}$ ), donde se formou o verbo $\alpha i \alpha ́ \zeta \omega$. V. Ov., Met., X, 215... 
(Página deixada propositadamente em branco) 


\section{HERMES E APOLO [17]}

1] Hermes - Pensar eu, ó Apolo, que esse $\operatorname{coxo}^{85}$, que exerce um ofício tão vil ${ }^{86}$, desposou as mais formosas divindades — Afrodite e uma Cárite! ${ }^{87}$

APOLO - Foi mesmo uma sorte, [caro] Hermes. Mas o que me causa maior admiração é que elas suportem ter relações com ele, especialmente quando o vêem escorrendo em suor, curvado sobre a forja, com o rosto coberto de fuligem, e mesmo assim abraçam-no, beijam-no e dormem com ele.

HERMES - E isso que me irrita e me faz ter inveja de Hefesto: tu, Apolo, cuidas da tua cabeleira, tocas cítara e orgulhas-te da tua formosura, e eu [que me orgulhe] da minha bela figura e da minha lira... Depois, quando tivermos que nos ir deitar, dormiremos sem companhia.

2] APOLO - Pelo que me toca, aliás, sou infeliz em coisas de amor, pelo menos no que toca a duas pessoas que muito amei — Dafne e Jacinto: a primeira foge de mim e odeia-me a tal ponto, que preferiu transformar-se em árvore a ter relaçóes comigo; e o segundo morreu com um golpe de um disco, e agora, em vez dessas pessoas, tenho [apenas] coroas.

HERMES - Em tempos, Afrodite foi por mim... Bem... não é coisa de que me gabe.

APOLO - Eu sei... Até se diz que ela deu à luz Hermafrodito, por obra tua. Mas... diz-me cá, se souberes, porque é que nem Afrodite tem ciúmes da Cárite, nem a Cárite de Afrodite?

3] HERMES - É que, [meu caro] Apolo, uma [a Cárite] vive com ele em Lemnos, enquanto Afrodite vive com ele no céu. Além disso, Afrodite ocupa a maior parte do seu tempo com Ares, por quem está apaixonada, de modo que pouco de preocupa com esse ferreiro.

APOLO - Achas que Hefesto sabe disso?

HERMES - Sabe, pois... Mas que poderá ele fazer perante um jovem valente e soldado [de profissão]? Por isso, Hefesto fica quieto, mas ameaça-os de lhes fabricar uma espécie de

${ }^{85}$ Hefesto, que os Romanos denominavam Vulcano, o ferreiro dos deuses.

${ }^{86}$ Outros mss. dizem, mais explicitamente (talvez por obra de um copista ou comentador mais obsequioso) «ferreiro de seu ofício».

${ }^{87}$ Trata-se de uma das três Graças, Aglaia; as outras duas são Eufrósine e Talia. 
armadilha que os enrede no momento em que eles estejam [os dois] na cama.

APOLO - Não sei... mas bem gostaria de ser eu o apanhado. 


\section{Hera e Latona [18]}

1] HERA - São muito formosos, ó Latona, os filhos que tu tiveste de Zeus.

LATONA - [Minha cara] Hera, nem todas podemos dar à luz filhos parecidos com Hefesto.

HERA - Mas esse, embora coxo, é-nos muito útil, um excelente artesão, que nos decorou o céu e desposou Afrodite, por quem é muito apreciado, ao passo que, dos teus filhos, uma [, Ártemis,] é varonil para lá da medida, muito amiga de andar pelos montes e, para concluir, quando vai à Cítia, toda a gente sabe como ela mata e devora estrangeiros, imitando assim os Citas antropófagos, enquanto Apolo se dá ares de saber tudo, de atirar ao arco, de tocar cítara, de ser médico, de ser adivinho; e, tendo estabelecido 'fábricas' de adivinhação em Delfos, em Claro, em Cólofon e em Dídimos, ludibriar os que o váo consultar, dando respostas tortuosas e de duplo sentido a cada uma das suas perguntas, para não correr o risco de errar... e lá vai enriquecendo por este processo, pois são muitos os tolos prontos a deixarem-se enganar. Todavia, não passa despercebido às pessoas sensatas que, muitas vezes, ele mente. Assim, ele, o próprio adivinho, por um lado, desconhecia que havia de matar o seu amado com o disco, e, por outro lado, não previu que Dafne lhe fugiria, por muito formoso e bem encabelado que ele fosse. Por isso, não vejo por que motivo tens a reputaçáo de ter melhores filhos que Níobe.

2] LATONA — Seja como for, esses meus filhos, a 'matadora de estrangeiros' e o 'falso adivinho', sei bem como te aflige vê-los entre os deuses, principalmente pelo facto de ela ser elogiada pela sua formosura e ele ser admirado por todos, quando toca cítara.

HERA - Ó Latona, fazes-me rir! Digno de admiração, esse, que Mársias teria esfolado, como vencedor na competição musical, caso as Musas tivessem decidido pronunciar uma sentença justa?! Mas quem morreu, injustamente vencido, foi o desgraçado. E quanto à tua formosa donzela, é tão formosa, que, quando se apercebeu de que fora vista [toda nua] por Actéon, receando que o jovem revelasse a sua fealdade, açulou os cães contra ele... Isto para náo dizer que, se ela ainda fosse realmente virgem, náo viria em socorro das parturientes.

LATONA - Ó Hera, estás toda orgulhosa por dormires com Zeus e reinares juntamente com ele, e por isso me insultas com 
todo o atrevimento; mas deixa estar que em breve te verei de novo a chorar. quando ele te abandonar e descer à terra disfarçado de touro. 


\section{Apolo e Hermes [21]}

\section{1] APOLO - De que é que está a rir, ó Hermes?}

HERMES - Porque, ó Apolo, vi uma cena muitíssimo risível.

APOLO - Conta cá, para que eu oiça e tenha também motivo para rir.

HERMES - Afrodite foi surpreendida na cama com Ares, onde Hefesto os apanhou e amarrou.

APOLO - Como foi isso? Parece que tens uma história saborosa para contar.

HERMES - Desde há muito, creio eu, que Hefesto, sabedor do caso, tentava apanhá-los; então, tendo colocado à volta do leito uma rede invisível, saiu para trabalhar na forja. Em seguida, entra Ares, às escondidas... segundo julgava... mas Hélio enxerga-o lá de cima e vem contar a Hefesto. Ora, quando já tinham subido para o leito e estavam já em pleno trabalho, na zona de acção da armadilha, eis que a rede os envolveu... e depois apareceu Hefesto. Afrodite, que estava toda nua, náo tendo maneira de se cobrir, ficou envergonhada, enquanto Ares, de início, tentou escapar-se, esperando rebentar com as malhas da rede, mas depois percebendo que se encontrava sem possibilidade de fugir, pôs-se a suplicar.

\section{2] APOLO - E então? Hefesto libertou-o?}

HERMES - Não imediatamente, mas antes convocou os deuses, a fim de lhes mostrar o adultério. Eles, ambos nus, de olhos baixos e amarrados, estavam corados [de vergonha]. Pareceu-me um espectáculo deleitoso, por pouco que não vimos praticar o próprio acto.

APOLO - Então e esse ferreiro não se envergonha de ser ele próprio a revelar a vergonha causada ao seu casamento?

HERMES - Qual quê! Até se pôs a rir fazendo coro com os outros [deuses]. Cá por mim, para ser franco, fiquei com inveja de Ares, ao vê-lo náo só fornicando com a formosíssima deusa, mas também amarrado juntinho a ela.

APOLO - Quer dizer que te sujeitarias a ser amarrado em idênticas circunstâncias?

HERMES - E tu não, ó Apolo? Vem cá vê-los. Louvar-teei, se, depois de os veres [naquela posição], não desejares o mesmo que eu. 
(Página deixada propositadamente em branco) 


\section{Hera e Zeus [22]}

1. HERA - Ó Zeus, eu teria vergonha de ter um filho assim, tão efeminado e tâo viciado na bebida, com os cabelos atados com uma fita, quase sempre acompanhado de mulheres desvairadas, ainda mais delicado que elas, dançando ao som de tambores, flautas e címbalos, em suma, parecido com qualquer outro, menos contigo.

ZEUS - E no entanto, ó Hera, esse tal, que usa fitas de mulher [no cabelo] e é mais delicado que elas, não só conquistou a Lídia, venceu os habitantes do Tmolo e submeteu os Trácios, mas também, tendo ido com um exército de mulheres numa expedição contra os Indos, capturou-lhes elefantes, conquistou o país e trouxe como refém o seu rei, que durante um certo tempo tinha ousado resistir-lhe; e realizou todas estas façanhas ao mesmo tempo que saltava e dançava, tendo na mão apenas tirsos de hera, embriagado, como tu dizes, e possesso. E se [como já sucedeu] alguém se atreveu a insultá-lo e a proferir ofensas contra os seus mistérios, ele puniu-o, quer amarrando-o com sarmentos de videira, quer fazendo-o despedaçar pela própria mãe, como se fosse uma corça ${ }^{88}$. Vês como estas façanhas são viris e não indignas de seu pai? Se a essas façanhas ele acrescenta brincadeiras e prazeres, isso não tem nada de censurável, especialmente se pensarmos do que é que ele seria capaz em estado de sobriedade, se, embriagado, faz tais coisas.

2. HERA - Parece-me que vais louvar a sua invenção, a vinha e o vinho, mesmo vendo o que fazem os ébrios, tropeçando, entregando-se a actos de violência ou, numa palavra, tornados loucos por acção do vinho. Icário, por exemplo, a quem ele primeiro deu a videira, foi morto a golpes de enxada pelos seus companheiros de bebida.

ZEUS - Isso não prova nada. Na verdade, não é o vinho nem Dioniso que provocam essas coisas, mas sim o excesso de bebida e o facto de uma pessoa se encher de vinho puro ${ }^{89}$ para

${ }^{88}$ Referência a Penteu, rei de Tebas, que violou os mistérios dionisíacos e foi despedaçado pelas bacantes e por sua própria mãe, Ágave, que, na sua fúria, viram nele uma corça.

${ }^{89}$ Os antigos costumavam beber vinho misturado com água; só os beberrôes o bebiam vinho puro: Adde merum! «chega-lhe do puro!» diz Horácio. 
além do que é decente. Mas quem beber moderadamente ficará mais alegre e mais agradável, e aquilo que se passou com Icário não se passaria com nenhum dos convivas. Mas... ó Hera, parece que ainda estás com ciúmes, lembrada [do episódio] de Sémele, a ponto de depreciares as belas qualidades de Dioniso. 


\section{Afrodite e Eros [23]}

1. AFrodite - Ó Eros, porque é que tu, que já venceste todos os outros deuses - Zeus, Posídon, Apolo, Reia, e até a mim, tua mãe — só te absténs de Atena? No caso desta, o teu facho não tem chama, a tua aljava está vazia de setas, tu não tens arco e perdeste a pontaria.

EROS - É que eu, minha mãe, tenho pavor dela, pois é aterradora, tem olhos claros chispantes e é terrivelmente varonil. Então, quando, de arco tenso, me dirijo na sua direcção, ela aterroriza-me, agitando o penacho: fico a tremelicar, e as setas escorregam-me das mãos.

AFRODITE - Mas então Ares não era mais temível? E no entanto, tu desarmaste-o e venceste-o.

EROS - Mas esse avança contra mim com ar decidido e desafia-me, ao passo que Atena me fixa de alto a baixo. Uma vez, esvoaçava eu por acaso perto dela, com o meu facho, quando ela me disse: "Se te aproximas de mim, juro pelo meu pai que te trespasso com a minha lança ou que te pego por um pé e te lanço no Tártaro, ou então que te despedaço e...»... Proferiu muitas outras ameaças do género. Fixa-me com olhar severo, e, além disso, acima do peito tem um rosto ameaçador, com uma cabeleira repleta de víboras, coisa que eu temo muitíssimo: sempre que vejo aquela coisa, fujo apavorado.

2. AFRODITE - Mas então, segundo dizes, tens medo de Atena e da Górgona, tu que não temes o raio de Zeus? E as Musas, por que motivo as deixas incólumes e livres das tuas frechadas? Será que elas agitam o penacho e te fazem ver Górgonas?

EROS - É que a essas, minha mãe, eu tenho respeito, pois são veneráveis, sempre em meditação ou ocupadas com o canto, de modo que eu, muitas vezes, aproximo-me delas, fascinado pela sua melodia.

AFRODITE - Deixemos essas, já que são veneráveis. Mas então Ártemis, porque é que não a feres?

EROS - Em primeiro lugar, porque não é possível agarrá-la, sempre a fugir por esses montes; e depois, porque ela já tem uma paixão muito sua.

AFRODITE - [Paixão] por quem, meu filho?

EROS - Pela caça, por cervos e corças, que ela persegue e apanha, abatendo-os com frechadas; em suma, está sempre nesta 
actividade. Mas o irmão dela, muito embora seja também um [grande] arqueiro e «atire muito longe a flecha»...

AFRODITE - Já sei, meu filho: já lhe mandaste muitas frechadas. 


\section{Zeus, Hermes, Hera, Atena, Afrodite, Páris (O JULGAMENTO DAS DEUSAS)}

1] ZEUS - Ó Hermes, toma lá esta maçã e vai à Frígia, vai ter com o filho de Príamo, o pastor, que guarda [o gado] no pico do Gárgaro, no monte Ida, e diz-lhe o seguinte: «Páris, Zeus ordena-te que, visto seres formoso e entendido em coisas de amor, que julgues, de entre as deusas, qual delas é a mais bela, e que a vencedora receba esta maçá como prémio do concurso." Portanto, [deusas,] é tempo de vos dirigirdes junto do juiz. Por mim, nego-me a ser árbitro, pois amo-vos por igual, pelo que, se fosse possível, dar-me-ia o maior prazer ver-vos todas vencedoras. Além disso, é fatal que aquele que atribuir o prémio de beleza a uma, fique odiado pelas outras [duas]. Por isso, eu não sou o juiz adequado ao vosso caso; mas o jovem frígio que vós ides procurar é de família real, parente aqui do Ganimedes e, de resto, muito simples e rústico; ninguém o julgaria indigno de assistir a um tal espectáculo.

2] AFrodite — Cá por mim, ó Zeus, mesmo que nomeasses o próprio Momo como nosso juiz, eu iria com toda a confiança para o desfile. Sim, que é que Momo poderia... momar contra mim? Mas é preciso que a criatura agrade também a estas senhoras.

HERA - Ó Afrodite, nós não temos medo, mesmo que fosse o teu [querido] Ares encarregado da arbitragem. Mas enfim, aceitamos esse tal Páris, seja lá ele quem for.

ZEUS - Estás de acordo com elas, minha filha? É o quê? viras o rosto e coras? Na verdade, é característico de vós, donzelas, envergonhar-vos destas coisas. Em todo o caso,, dás o teu assentimento. Portanto, ide que as vencidas não se zanguem com o juiz nem façam mal ao jovem, pois não é possível que todas vós sejais [declaradas] igualmente belas.

3] HeRmes - Partamos imediatamente para a Frígia: eu vou à frente, e vós vinde atrás de mim e... coragem, que eu conheço Páris, sei que é um jovem formoso e, além disso, dado a coisas de amor e capacíssimo de julgar tais demandas: esse não pronunciaria nunca uma sentença injusta. 
AFrodite - Tudo isso que me estás a dizer é muito bom... o facto de o juiz ser justo... Mas... esse tal [fulano] é solteiro ou vive com uma mulher?

HERMES - Bem, Afrodite... não é completamente solteiro.

AFRODITE - É o quê?

HERMES - Creio que vive com ele uma certa mulher do monte Ida, engraçadota, mas rude e terrivelmente rústica. Mas náo parece que ele esteja muito apegado a essa mulher. Mas... porque fazes essa pergunta?

Afrodite - Perguntei por perguntar.

4] ATENA - Ó tu aí! Estás a faltar aos deveres de embaixador, há tanto tempo a falar com essa fulana em particular.

HERMES - Ó Atena, não é nada de mal, nada contra vós as duas: ela apenas me perguntou se Páris é solteiro.

ATENA — E para quê essa conversa tão indiscreta?

HERMES - Não sei... Ela diz que foi apenas uma ideia que lhe ocorreu... que perguntou sem qualquer intenção especial.

ATENA - E então? Ele é solteiro?

HERMES - Não creio.

ATENA - E depois? Ele tem predilecção para as coisas da guerra, é ambicioso de glória... ou é apenas um boieiro?

HERMES - Não te sei dizer ao certo, mas é de supor que, sendo jovem, anseie por alcançar tudo isso e pretenda ser o primeiro nas batalhas.

AFRODITE - Estás a ver? Eu não te censuro nem te acuso de falares com ela em particular, pois Afrodite não é dada a queixumes por coisas desse género.

HERMES - Ela fazia-me quase a mesma pergunta que tu. Portanto, não leves a mal nem cuides que ficas desfavorecida, pois eu respondi-lhe também da maneira mais natural...

5] ... Mas... com toda esta conversa, já andámos muito e nos afastámos [bastante] das estrelas e estamos quase a chegar à Frígia. Já avisto nitidamente o [monte] Ida e todo o pico Gárgaro e, se não me engano, o vosso juiz, Páris.

HERA - Onde está ele, que não estou a vê-lo?

HERMES - Olha aqui para este lado, Hera, para a esquerda, e não para o alto do monte, mas para a encosta, onde vês a sua caverna e a sua manada.

HERA - Não vejo nenhuma manada. 
HERMES - Como dizes? Não estás a ver, assim, na direcção do meu dedo, uns bezerros saindo do meio das rochas e um fulano a correr rochedo abaixo, com um cajado na mão, tentando impedir a manada de se dispersar?

HERA - Agora sim, já estou a ver... se é que é mesmo ele...

HERMES - Mas é mesmo ele. E já que estamos perto da terra, desçamos, por favor, e caminhemos a pé, para não o assustarmos, se descêssemos cá de cima e repentinamente em voo picado.

HERA - Dizes bem: façamos desse modo. Bem... agora que já poisámos, compete-te a ti, Afrodite, ir à frente a indicar-nos o caminho, pois tu, naturalmente, tens experiência deste caminho, pelo facto de, como é voz corrente, teres descido até aqui para te encontrares com Anquises.

AFRODITE - Ó Hera... esses teus remoques não me aquecem nem me arrefecem...

6] HERMES - Pois quem vos guiará sou eu, uma vez que eu próprio passei algum tempo no [monte] Ida, no tempo em que Zeus estava apaixonado pelo jovem frígio ${ }^{90}$. Muitas vezes vim a este lugar, enviado por Zeus, a fim de espiar o rapaz, e, quando Zeus se transformou em águia, eu voava a seu lado e confortava o formoso jovem. Se bem me recordo, foi deste rochedo que ele o raptou: estava o jovem a tocar flauta junto do rebanho, quando Zeus, descendo por detrás dele, o envolveu muito suavemente nas garras e, agarrando com o bico a fita que ele tinha a envolver a cabeça, elevou-se no ar, levando consigo o jovem aterrorizado, que voltava o pescoço para ver [o seu raptor]. Entáo eu, apanhando a flauta, que ele, cheio de medo, tinha largado... Mas... eis-nos chegados ao pé dele, pelo que temos de o saudar:

\section{7] "Ora viva, pastor!»}

PÁRIS — "Igualmente, meu jovem». Quem és tu, que vens a esta nossa terra? E quem são essas mulheres que trazes contigo? $\mathrm{Na}$ verdade, belas como são, não parecem feitas para viverem nas montanhas.

HERMES - Mas, ó Páris, não são mulheres. Estas que estás a ver são Hera, Atena e Afrodite, e eu sou Hermes, aqui enviado por Zeus. Mas... porque estás a tremer e a ficar pálido?

\footnotetext{
${ }^{90}$ Ganimedes (v. Índice mitológico).
} 
Não tenhas receio, pois não se trata de nenhum assunto desagradável: Zeus ordena-te que sejas o juiz da beleza destas [deusas], pois — diz ele — tu és formoso e entendido em coisas de amor. Deixo ao teu cuidado a sentença, mas, quanto ao prémio do concurso, tomarás dele conhecimento lendo o que está inscrito na maçá.

PÁRIS - Vejamos então o que é que ele quer... Está escrito: «PARA A MAIS BELA». Mas... ó Hermes, meu Senhor, como é que eu, simples mortal e homem rude, poderia ser juiz num espectáculo tão extraordinário e acima das possibilidades de um pastor? Julgar assuntos como este é coisa mais para pessoas finas e urbanas. Pela minha parte, mal seria capaz de julgar, segundo a minha profissão, se uma cabra é mais bonita que outra cabra ou uma vitela mais bonita que outra vitela...

8] ... Mas estas são todas igualmente formosas... não sei como é que [o juiz] poderia desviar o olhar de uma para o fazer incidir sobre outra, pois não quereria facilmente afastá-lo, mas, onde primeiro se fixasse, aí ficaria preso e elogiaria aquela que tivesse à frente; mas, se lançasse os olhos para outra, achá-la-ia igualmente bela, fixar-se-ia nela e ficaria cativado com tudo o que via. Em resumo, a beleza destas deusas penetra-me e envolve-me todo, e só lamento não poder, como Argos, ver com todo o meu corpo. Creio que pronunciaria um julgamento justo, se desse a todas a maçã. E tem mais: acontece que uma é irmã e esposa de Zeus, e as outras são filhas deste. Portanto, como é que este julgamento pode deixar de ser difícil?

HERMES - Não sei, mas não é possível furtar-se a [cumprir] uma ordem de Zeus.

9] PÁRIS - Ó Hermes, convence as deusas de uma única coisa: que as duas vencidas fiquem zangadas comigo, mas que considerem que o erro foi somente dos meus olhos.

HERMES - Elas comprometem-se a proceder desse modo. Bem: já é tempo de procederes ao julgamento.

PÁRIS - Procedamos. Sim, que remédio... Ora, em primeiro lugar, quero saber como devo examiná-las: tal como elas se encontram, ou se será necessário despirem-se, por respeito pelo rigor do julgamento.

HERMES - Isso é assunto da competência do juiz: dá as tuas ordens como entenderes.

PÁRIS - Como entender? Quero examiná-las todas nuas. 
HERMES - Vocês aí, dispam-se! E tu examina-as, que eu já virei a cara.

10] HERA - Muito bem, Páris, serei a primeira a despir-me, para que saibas que não só possuo «níveos braços» e me gabo de ter "[grandes] olhos de vaca», mas que sou igualmente bela em todo o corpo.

<PÁRIS - Despe-te também tu, Afrodite. ${ }^{91}$

ATENA - Ó Páris, não a deixes despir-se, sem que ela tire a cinta, que tem poderes mágicos, não se dê o caso de te seduzir por esse meio. Na verdade, ela não devia apresentar-se assim ataviada e de cara pintada, como qualquer cortesá, em vez de mostrar a sua beleza nua e sem artifícios.

PÁRIS - Elas têm razão no que respeita à tua cinta. Por isso, tira-a.

AFrODITE - Então e tu, Atena, porque é que não tiras o elmo e mostras a cabeça desguarnecida, em vez de agitares o penacho para amedrontar o juiz? Ou será que receias que te critiquem a cor cinzenta dos olhos, patente sem esse elmo aterrorizante?

ATENA - Pronto, já tirei o elmo.

AFRODITE - Pronto, também a cinta.

HERA - Então dispamo-nos.

11] PÁRIS - Ó Zeus prodigioso! Que espectáculo! Que beleza! Que deleite! Veja-se esta jovem, como irradia dela um brilho real e augusto, verdadeiramente digno de Zeus! Veja-se aquela, com um sorriso tão doce, tão delicado, tão provocante, que até já me sinto no cúmulo da felicidade... Mas agora, se me dão licença, quero examinar cada uma em particular, pois neste momento estou indeciso, não sei em qual hei-de fixar-me, os meus olhos estão divididos de todos os lados...

AFRODITE - Façamos assim.

PÁRIS - Vós as duas retirai-vos, e tu, Hera, fica.

HERA - Ficarei. Depois de me teres examinado atentamente, será tempo de considerar também outra coisa: se são belos os presentes pela votação a meu favor. Sim, Páris, se sentenciares que sou eu a mais bela, far-te-ei dono e senhor de toda a Ásia.

${ }^{91}$ Acrescento (emenda) de Mras. 
PÁRIS - Não é do meu carácter deixar-me influenciar por presentes. Mas retira-te. A sentença será conforme com a minha consciência. Que se apresente Atena.

12] Atena - Aqui estou, Páris. Se a seguir me julgares a mais belas, nunca sairás vencido de nenhum combate, mas sempre vencedor, pois farei de ti um guerreiro e um vencedor.

PÁRIS - Ó Atena, eu náo tenho necessidade de guerras ou de combates, pois, como vês, a paz reina em toda a Frígia e na Lídia, e os domínios de meu pai estâo livres de inimigos. Mas anima-te, pois não serás prejudicada, embora eu não julgue baseado em presentes. Bem, agora veste-te e póe o elmo. É tempo de se apresentar Afrodite.

13] Afrodite - Aqui estou eu em pessoa junto a ti. Examina com muita atenção cada parte, sem descurar nenhuma, mas demorando-te em cada uma delas. Se te apraz, meu belo, escuta o que eu tenho para te dizer. $\mathrm{Na}$ verdade, desde há muito tempo que, olhando para ti, jovem e belo como não sei de outro que a Frígia tenha produzido, te felicito pela tua formosura, mas também te censuro por não teres já deixado as grutas e estas fragas, para viveres na cidade, em vez de desperdiçares a tua beleza neste ermo. Sim, que prazer poderias tu tirar das montanhas? Que é que as tuas vacas ganham com a tua beleza? Tu já devias estar casado, não com uma mulher rústica e grosseira, como são as do monte Ida, mas com uma mulher da Grécia: de Argos, ou de Corinto, ou da Lacónia, como, por exemplo, Helena, jovem e bela, em nada inferior a mim, e - ainda mais importante - de índole apaixonada. Sim, estou convencido de que bastaria que, mal ela te visse nem que fosse uma vez, deixaria tudo, entregar-se-ia toda a ti e seguir-te-ia para ir viver contigo. Certamente que já ouviste falar dela.

PÁRIS - Nunca, Afrodite, mas agora tenho todo o prazer em ouvir-te contar tudo isso.

14] Afrodite - Ela é filha dessa formosa Leda, para junto da qual Zeus desceu transformado em cisne.

PÁRIS - E como é ela fisicamente?

AFRODITE - É alva, como é natural que seja uma filha de cisne, delicada, por ser criada dentro de um ovo, e a maior 
parte das vezes nua e de porte atlético; na verdade, é tão pretendida, que se gerou uma guerra por sua causa, quando Teseu a raptou ainda em idade imatura. Mal, porém, atingiu à idade adulta, todos os nobres aqueus se apresentaram como seus pretendentes, mas o preferido foi Menelau, da família dos Pelópidas. Mesmo assim, se quiseres, poderei arranjar-te casamento com ela.

PÁRIS - É o quê? Com uma mulher casada?

AFRODITE - És muito novinho e muito ingénuo, mas eu sei como preparar a coisa.

PÁRIS - Mas como? Sim, quero saber.

15] Afrodite - Antes de mais, sairás do teu país, a pretexto de ires visitar a Grécia; depois chegarás à Lacedemónia, onde Helena te verá... e, a partir daí, é tarefa minha fazer que ela se apaixone por ti e te siga.

PÁRIS - Isso parece-me uma coisa incrível, que ela deixe o marido e queira embarcar com um bárbaro e estrangeiro.

Afrodite - Não te dê cuidado, pois eu tenho dois belos filhos, Hímero ${ }^{92}$ e Eros; entregar-te-ei ambos, para que sejam teus guias durante a viagem: Eros, penetrando no coraçáo da mulher, forçá-la-á a ficar apaixonada; e Hímero, introduzindo-se em ti, tornar-te-á, tal como ele, desejável e amável. Eu mesma, sempre presente, pedirei às Cárites que nos acompanhem, para assim, todos juntos, convencermos Helena.

PÁRIS - Não sei, Afrodite, como correrá a aventura, mas o que é certo é que já estou apaixonado por Helena e, não sei lá como, já me julgo estar a vê-la e me imagino a navegar a caminho da Grécia, a entrar em Esparta e a regressar de lá com essa mulher... Só lamento não estar já neste momento a fazer realmente tudo isso.

16] Afrodite - Mas, ó Páris, não fiques assim tão entusiasmado, antes de me pagares, com o teu julgamento, a minha função de alcoviteira e mediadora, pois ficaria bem que eu me colocasse a vosso lado já como vencedora [deste concurso] e festejasse, o ao mesmo tempo, o vosso casamento e a minha vitória. Na verdade, está nas tuas mãos comprar, com uma [simples] maçã, o amor, a beleza, o casamento.

${ }^{92}$ Hímero, o Desejo; Eros, o Amor (o Cupido latino). 
PÁRIS - Receio que, depois do julgamento, não penses mais em mim.

AFRODITE - Queres que jure?

PÁRIS - De maneira nenhuma... mas promete outra vez.

AFRODITE - Prometo dar-te Helena por tua esposa; que ela seguir-te-á e que chegará a Îlion, vossa terra; e eu própria estarei presente e farei tudo o que for preciso.

PÁRIS - E trarás contigo Eros, Hímero e as Cárites?

AFRODITE - Fica descansado, que, além destes, também levarei Poto e Himeneu.

PÁRIS - Sendo assim, em troca disso, dou-te a maçãa: toma. 


\section{Ares e Hermes [1]}

1] ARES - Ó Hermes, ouviste as ameaças que Zeus nos fez, tão arrogantes e tão disparatadas? «Se eu quiser — disse ele —, deito uma corda cá do céu, e vós todos, pendurados nela, esforçar-vos-eis por me arrastar ai para baixo, mas será esforço baldado: não me mandareis abaixo. E se eu quisesse, içar-vos-ia não só a vós, mas também puxaria ao mesmo tempo a terra e o mar e suspendê-los-ia no espaço.» E muitas outras coisas que tu também ouviste. Por mim, não posso negar que ele seja superior e mais forte que cada um de nós um por um, mas que ele seja superior a todos nós juntos, a ponto de não o vergarmos com o nosso peso, mesmo que acrescentássemos a terra e o mar, nisso é que eu já não posso acreditar.

2] HERMES - Está calado, Ares, pois não é prudente falar dessas coisas, não se dê o caso de sermos castigados pela nossa linguarice.

ARES - Cuidas tu que eu tive esta conversa com toda a gente, e não apenas contigo, que eu bem sei que tens tento na língua? Ora, eu náo podia deixar de te contar uma ameaça que eu ouvi e que me pareceu sumamente ridícula. $\mathrm{Na}$ verdade, recordo-me de que, não há muito tempo, quando Posídon, Hera e Atena se revoltaram e conspiraram contra Zeus no sentido de o prender e pôr a ferros, ele ficou completamente aterrado... e eram apenas três; e se Tétis, com pena dele, náo tivesse chamado em seu socorro Briareu, [o gigante] de cem braços, teria mesmo ficado a ferros, juntamente com o seu raio e o seu trovão. Ao pensar neste episódio, desatei a rir da fanfarronice de Zeus.

HERMES - Cala-te, repito! Não é prudente nem para ti dizer tais coisas, nem para mim escutá-las. 
(Página deixada propositadamente em branco) 


\section{PÁ e Hermes [2]}

\section{1] PÁ — Ora viva, meu pai Hermes!}

HERMES - Já eu não digo o mesmo... mas... como é que eu sou teu pai?

PÃ - Por acaso não és tu Hermes, do monte Cilénio?

HERMES - Claro que sim. Mas entáo como é que és meu filho?

PÁ - Sou teu filho bastardo, nascido de uma tua relação amorosa.

HERMES - Por Zeus, talvez antes dos amores espúrios de algum bode com uma cabra... mas meu [filho]?... Como é isso possível, com cornos, com esse focinho, uma barba emaranhada, patas fendidas de bode e cauda a sobressair do traseiro?

PÃ - Ó meu pai, quaisquer zombarias que me dirigires, estás a pôr em situação censurável o teu próprio filho, ou melhor, a ti próprio, por teres gerado e criado uma tal criatura. Eu é que não tenho culpa [de nada].

HERMES - Mas então quem é que dizes que é a tua mãe? Porventura, sem o saber, tive relaçôes adúlteras com uma cabra?

PÃ - Não, não tiveste relaçóes com uma cabra, mas lembra-te de uma vez, na Arcádia, em que violaste uma donzela livre. Porque mordes no dedo, [a fingir que] procuras [lembrar-te]? Refiro-me à filha de Icário, Penélope.

HERMES - Então por que razão é que ela te deu à luz assim parecido, náo comigo, mas com um bode?

2] PÁ - Vou dizer-te as próprias palavras dela. Na verdade, quando me estava a enviar para a Arcádia, disse: «Meu menino, a tua mãe sou eu, Penélope de Esparta. Quanto ao teu pai, fica sabendo que é Hermes, filho de Maia e de Zeus. Não te aflijas por teres cornos e pés de bode: a razão é que, quando o teu pai teve relaçôes comigo, veio disfarçado de bode, para passar despercebido. É por isso que tu saiste parecido com um bode."

HERMES - Por Zeus, recordo-me de ter feito uma coisa desse género. Mas, lá por isso, eu, tão vaidoso da minha formosura, eu, ainda imberbe, hei-de ser chamado teu pai e ser motivo da troça de toda a gente, pelo lindo filho que gerei?

3] PÁ - Deixa lá, pai, que não vou envergonhar-te, pois sou músico e toco flauta maravilhosamente; além disso, Dioniso náo pode fazer nada sem mim, que até me fez seu companheiro 
e chefe de dança. Se visses os meus rebanhos, todos os que eu possuo na regiáo de Tegeia e no cimo do Parténio, ficarias muito contente. Sou senhor de toda a Arcádia. Muito recentemente, lutando ao lado dos Atenienses em Maratona, portei-me tão heroicamente, que me foi atribuída como prémio a gruta sob a Acrópole. Portanto, se fores a Atenas, saberás quáo prestigiado é aí o nome de Pá.

4] Hermes - Diz-me cá: és casado, Pã (Julgo que é assim que te chamam)?

PÁ — De maneira nenhuma, meu pai; é que... sou muito dado ao amor... tanto que náo gostaria de viver com uma única mulher.

HERMES - Quer dizer que te atiras às cabritas?!

PÁ - Estás a escarnecer de mim. Convivo com as ninfas Eco e Pítis e com todas as Ménades de Dioniso... e sou muito cortejado por elas.

HERMES - Bem, meu filho, sabes que favor - o primeiro que te peço - gostaria que me fizesses?

PÁ - Dás as tuas ordens, meu pai, e depois veremos.

HERMES - Vem visitar-me e apresentar os teus respeitos... mas vê lá não me chames pai quando alguém puder ouvir. 


\section{Apolo E Dioniso [3]}

1] APOLO — Que diremos disto, Dioniso? Eros, Hermafrodito e Priapo, irmãos filhos da mesma mãe, são os seres mais dissemelhantes do ponto de vista físico e da ocupação. Um deles - Eros - é mui formoso, bom arqueiro, dotado de grande força e senhor de tudo; outro - Hermafrodito — de aparência feminina, masculina e ambígua... ninguém seria capaz de distinguir se é rapaz ou rapariga; e o outro — Priapo — é viril para lá da decência.

DIONISO — Não te admires, Apolo; na verdade, Afrodite não tem culpa disso, mas sim os pais, que eram diferentes; e mesmo assim, muitas vezes, os que têm o mesmo pai e nasceram do mesmo ventre, um é macho e o outro é fêmea, como vós - [tu e tua irmã Ártemis].

APOLO - Sim, mas nós somos iguais e temos a mesma ocupação: ambos somos arqueiros.

DIONISO - Até isso do arco, Apolo, sois iguais, mas já não são iguais noutros aspectos, pois Ártemis mata estrangeiros ma Cítia, ao passo que tu praticas a adivinhação e curas os doentes.

APOLO - Julgas que a minha irmã gosta dos Cítios, ela que, mal um grego chegou um dia à Táurica, ficou pronta para zarpar dali juntamente com ele, horrorizada com as mortandades?

2] DiOnisO - E fez ela muito bem. Mas, quanto a Priapo... vou contar-te um caso muito engraçado: aqui há tempos, estando eu em Lâmpsaco, passeava pela cidade, quando ele me acolheu e recebeu em sua casa. Ora, quando, já bastante bem bebidos, tínhamos adormecido na sala de jantar, o nosso valentão, aí pelo meio da noite, levantou-se e... tenho vergonha de dizer.

APOLO - Tentou seduzir-te, Dioniso?

DIONISO - Mais ou menos.

APOLO - E tu como é que reagiste?

DIONISO - Ora, que havia de fazer, senão rir?

APOLO - E fizeste muito bem, sem azedume e sem cólera. De facto, ele tem desculpa, pois tentou seduzir uma bela figura como tu.

DIONISO - Nessa ordem de ideias, Apolo, ele poderia estender a tentativa até à tua pessoa, pois és formoso e tens uma longa cabeleira, de modo Priapo, mesmo sóbrio, poderia atirar-se a ti.

APOLO - Não há-de atirar-se, não, Dioniso, pois eu, além de cabeleira, tenho flechas. 
(Página deixada propositadamente em branco) 


\section{Hermes e Maia [4]}

1] HERMES - Ó minha mãe, haverá no céu algum deus mais desgraçado que eu?

MAIA - Ó Hermes, não digas uma coisa dessas.

HERMES - E porque náo hei-de dizer, se tenho tantas ocupaçóes, a trabalhar sozinho e disperso por tantos serviços? Realmente, logo de madrugada, tenho de me levantar para varrer a sala de jantar, estender a toalha de mesa, deixar tudo arrumado, apresentar-me diante de Zeus, levar as sua mensagens, fazendo de correio, para cima e para baixo, e, mal regresso, todo coberto de pó, tenho de lhe servir a ambrósia; e, antes de ele ter arranjado este novo escançáo, era eu próprio que lhe servia o néctar. Mas o mais terrível de tudo é que sou o único, de entre todos os deuses, que não durmo de noite, pois, mesmo entáo, tenho de levar as almas a Plutão, de servir de condutor de mortos e de estar presente no tribunal. E como não me bastassem as funçôes diurnas - assistir às competiçóes de luta, ser arauto nas assembleias e orientar os oradores —, ainda por cima sou muito solicitado para participar em cerimónias fúnebres.

2] No entanto, os filhos de Leda, passam, dia sim dia não, um no céu e o outro no Hades, ao passo que eu sou obrigado a fazer todos os dias o mesmo que eles. E os filhos de Alcmena e de Sémele, nascidos de míseras mulheres, passam a vida tranquilamente em banquetes, enquanto eu, filho da filha de Atlas, Maia, sou criado deles. Ainda agora acabo de chegar de Sídon, de casa da filha de Cadmo, aonde Zeus me enviou, a fim de observar como estava a jovem; e ainda eu náo tinha retomado fôlego, acaba de me mandar ir a Argos visitar Dánae, "e depois - disse ele - vais dai para a Beócia e, de caminho, dá uma olhadela a Antiope». Numa palavra, estou esgotado. Se pudesse, pedia, com todo o gosto, que me vendessem, como os pobres escravos lá da terra.

MAIA - Deixa lá, meu filho... Tu és jovem, deves obedecer a todas as ordens de teu pai. Agora, tal como foste mandado, corre já depressa para Argos, e depois para a Beócia, ainda assim não apanhes uma sova por te atrasares. 
(Página deixada propositadamente em branco) 


\section{ZeUS E HÉLIO [24]}

1] ZEUS - Que é que fizeste, tu, o mais ruim dos Titâs? Arruinaste tudo na terra, ao confiar o teu carro a um jovem insensato, que incendiou uma parte, aproximando-se demasiado da terra, e fez que a outra parte fosse destruída pelo gelo, ao afastar muito o fogo... Numa palavra, não houve nada que ele não transtornasse e confundisse. E se eu, tendo-me apercebido do que estava a acontecer, não o tivesse abatido com o meu raio, não teria sobrevivido nem um resto de humanidade. Que belo condutor, que belo auriga nos arranjaste!

HÉLIO - Eu errei, ó Zeus, mas não te irrites comigo, por me ter deixado convencer pelas súplicas do meu filho. Como é que eu podia esperar que daí resultaria uma tão grande catástrofe?

ZEUS - Não sabias quanta destreza requer esse trabalho? [Náo sabias] que, se uma pessoa sair, mesmo que pouco, da rota, deita tudo a perder? Também desconhecias a fogosidade dos teus cavalos, e que é absolutamente necessário puxar-lhes as rédeas? Se uma pessoa os deixa ir [à vontade], tomam logo o freio nos dentes, e foi assim que eles, à solta, levaram o jovem, [desviando-se] ora para a esquerda, ora logo a seguir para a direita, algumas vezes no sentido inverso da rota, ou mais para cima, ou mais para baixo... em resumo: para onde os cavalos quisessem, sem que o moço soubesse o que fazer deles.

2] HÉlio - De facto, eu sabia de tudo isso e, por esse motivo, resisti durante muito tempo sem lhe confiar a condução. Como o moço, porém, me suplicasse a chorar, e sua mãe Clímene fazendo coro com ele, eu fi-lo subir para o carro e indiquei-lhe como devia manter o andamento, até que ponto devia aliviar as rédeas para subir, como fazer para voltar a descer, como ficar senhor das rédeas e náo ceder à fogosidade dos cavalos. Também o avisei do risco [que corria], se náo conduzisse sempre a direito. Ele, porém, criança como era, ao entrar num fogo táo grande e ao debruçar-se sobre o profundo vazio [lá em baixo], ficou transido de medo, como era natural. Os cavalos, sentindo que não era eu quem os montava, desprezaram o jovem e desviaram-se da sua rota e provocaram todas essas tropelias. Então o moço, com medo - julgo eu — de cair dali abaixo, largou as rédeas agarrou-se ao varal do carro. 
Ora, o moço já pagou pelo que fez, e eu, ó Zeus, já tenho, com o meu luto, castigo que baste.

ZEUS - Castigo que baste, depois de uma tal audácia? Bem, desta vez concedo-te perdáo, mas, de hoje em diante, cometeres alguma infracção semelhante [a esta], ou se mandares no teu lugar alguém como esse [jovem], ficarás a saber até que ponto o meu raio é mais ardente que o teu fogo. Para já, que as suas irmãs o sepultem nas margens do Erídano, no local onde ele se precipitou do carro e caiu; que elas chorem lágrimas de âmbar e se transformem em choupos ${ }^{93}$, em sinal de luto. E tu concerta o teu carro, que tem o timáo quebrado e uma das rodas destroçadas, e atrela e conduz os cavalos. E lembra-te de tudo [o que te disse].

${ }^{93} \mathrm{Ou}$ "salgueiros», ou (designaçấo vulgar) «chorôes», que condiz melhor com o contexto. 


\section{APOLO E HERMES [25]}

1] APOLO - Ó Hermes, és capaz de me dizer qual destes dois é Castor e qual é Pólux? É que eu não sei distingui-los.

HERMES - Aquele que esteve ontem connosco, é Castor, e este é Pólux.

APOLO - Como é que os reconheces, se eles são iguais?

HERMES - É que este, ó Apolo, tem no rosto as cicatrizes dos golpes que recebeu dos seus adversários de pugilismo, sobretudo dos golpes que recebeu de Bébrice, filho de Âmico, quando da expedição em que viajava com Jasão. O outro náo apresenta nenhum destes sinais, mas tem o rosto limpo e ileso.

APOLO - Foste-me muito útil ${ }^{94}$ ao ensinares-me a diferençá-los, pois em tudo o resto são iguais: a mesma meia casca de ovo, a mesma estrela na cabeça, o mesmo dardo na mão, cada um com o seu cavalo branco, de tal maneira [iguais], que muitas vezes chamei Castor a Pólux e Pólux a Castor. Mas diz-me cá ainda uma coisa: por que motivo não vivem ambos connosco, mas cada um é alternadamente ora morto, ora divindade?

2] HERMES - Eles procedem deste modo por amor fraterno. $\mathrm{Na}$ verdade, como um dos filhos de Leda tinha de morrer, enquanto o outro seria imortal, eles repartiram deste modo a imortalidade.

APOLO - Ó Hermes, mas essa partilha não é sensata, já que, desse modo, náo se vêem um ao outro, que era - creio bem - o que eles desejavam. Então porque é que um está junto dos deuses, enquanto o outro está com os mortos? E... além disso, assim como eu profiro oráculos, Asclépio é médico, tu ensinas a lutar e és um excelente treinador de ginástica, Ártemis é parteira... enfim, cada um dos outros deuses tem a sua profissão, útil quer aos deuses, quer aos homens, estes dois que benefícios nos trazem? Será que, não fazem nada, a não ser estar à mesa... daquela idade?!

HERMES - De modo nenhum, pois foi-lhes ordenado que ficassem ao serviço de Posídon, devendo percorrer o mar a cavalo: no caso de verem marinheiros flagelados pelas tempestades, descem para dentro do barco e salvam a tripulação.

${ }^{94}$ Frase idiomática, que mantivemos, mas que pode ser traduzida por «Muito obrigado por me teres ensinado a diferençá-los». 
APOLO - Ó Hermes, mas que profissão salutar, essa de que falas. 


\section{DIÁLOGOS DOS DEUSES MARINHOS}


Texto da ed. de Karl Mras, Die Hauptwerke des Lukian 


\section{INTRODUÇÃo}

Sem esquecer as restantes obras de Luciano, as cenas e as personagens dos Diálogos abarcam alguns dos aspectos mais significativos da cultura, da sociedade e da mentalidade gregas no tempo do crítico que, fundamentalmente, Luciano foi, para além, já se vê, do grande escritor — qualidade que alguns modernos ainda persistem em apoucar.

Nos Diálogos das Cortesãs, o cenário e as personagens são, como do título se depreende, "terrestres»: é sobre um dos aspectos importantes da vida social, a vida extraconjugal dos homens e a correspondente "oferta" de serviços, que incide a crítica, desta vez não muito contundente, de um escritor do "grupo dos homens». Luciano fala de gente do seu tempo.

Os Diálogos dos Mortos têm por cenário o reino de Hades. Note-se, porém, que não se trata de diálogos dos deuses infernais, mas sim dos mortos, embora, naturalmente, aí figurem divindades infernais ou que têm algo que fazer nessas paragens. A crítica, no entanto, vai, quase toda ela, directa aos mortos ilustres, às sua ilusôes enquanto vivos e às suas decepçóes finais e definitivas.

Os Diálogos dos Deuses são inspirados na mitologia, tal como ela é apresentada pelos poetas, sobretudo Homero, Hesíodo e Hinos Homéricos, mas também, em certos casos, através de diferentes tradiçóes. A crítica incide sobre aspectos relativos à moralidade dos deuses e a acontecimentos mais ou menos incríveis, no seguimento implícito das críticas de Xenófanes, Platão e outros.

Finalmente, os Diálogos dos Deuses Marinhos, tal como os outros, retiram a sua inspiração dos poemas homéricos e outras tradições por vezes contraditórias, mas é bem visível, mais que noutros diálogos, a influência da pintura e da escultura.

Os deuses marinhos, na crítica de Luciano, têm os mesmos defeitos morais dos seus congéneres infernais ou celestes, mas, com excepçáo de certas cenas, aparecem-nos com um ar um pouco mais simpático. Embora o seu comportamento não deixe de escandalizar Luciano, ele compraz-se, sobretudo, em apontar aspectos verdadeiramente inacreditáveis, próprios para encantar poetas e seus leitores, mas indignos da crença de filósofos e intelectuais mais positivos. 
O leitor moderno pode e deve assumir as duas «leituras»: por um lado, a do homem comum, que náo detecta contradiçôes, que aceita essas narrativas como, pelo menos, verdadeiras enquanto são contadas, ou até como sendo a visão artística do poeta, do pintor ou do escultor, isto é, como elemento artístico-cultural; e, por outro lado, a leitura do céptico, o qual, ao tomar à letra as cenas e os eventos que fazem parte do currículo dos deuses, denuncia a falsidade não só da mitologia, mas da própria religião. Creio que Luciano fazia ambas as «leituras». 


\section{DIÁLOGOS DOS DEUSES MARINHOS}





\section{DóRide's E Galateia}

1] DÓRIDE - Ó Galateia, mas que belo amante é esse tal pastor siciliano, que dizem estar louco por ti!

GALATEIA - Não faças pouco de mim, Dóride, pois, seja como for, é filho de Posídon.

DÓRIDE - E daí? Mesmo que ele fosse filho do próprio Zeus, se aparecesse assim selvagem e peludo e - cúmulo da fealdade - com um único olho, cuidas tu que esta origem familiar lhe valeria de alguma coisa em termos de beleza?

GALATEIA - O seu corpo peludo não é - como tu dizes — selvagem e feio, mas sim másculo; e quanto ao olho [único], além de assentar bem na sua fronte, não vê menos bem do que se tivesse dois.

DÓRIDE - Ó Dóride, pela maneira como o elogias, até parece que Polifemo é, não tanto teu amador, mas sim teu amado.

2] GALATEIA — Ele não é meu amado... simplesmente não suporto esse teu ar ofensivo... até parece que é por despeito que assim procedes, pelo facto de ele, um dia em que apascentava o gado, ao ver-nos, lá do alto, brincando na praia, no sopé do Etna, no sítio em que se estende um areal entre a montanha e o mar, nem sequer ter olhado para ti, mas me considerou a mais formosa e só em mim fixou o seu olho. É isso que te atormenta, pois prova que eu sou melhor que tu e mais digna de ser amada, enquanto tu foste menosprezada.

DÓRIDE - Julgas-te digna de ser invejada, pelo facto de pareceres bela a um pastor de vista curta? Na verdade, que outra coisa poderia ele louvar em ti, a náo ser a tua brancura... e isso - creio - só pelo facto de estar habituado ao queijo e ao leite, pelo que julga belo tudo o que com eles se parece.

3] Aliás, se quiseres saber como é realmente o teu aspecto físico, olha para a água, do alto de um rochedo, em dia de mar calmo, e verás que não tens nada mais que pele alva. Ora, isso náo é coisa que se elogie, se não se lhe juntar um pouco de vermelho.

GALATEIA - Mesmo assim, eu, apesar da minha alvura sem mistura, tenho um amador, ainda que só este, ao passo que a ti

${ }^{95}$ Dóride (Dóris), filha de Oceano e irmã de Tétis, desposou seu irmão Nereu, de quem teve 50 filhas, as Nereidas. 
ninguém te elogia, seja ele pastor, marinheiro ou barqueiro. Aliás, Polifemo entre outras coisas, é músico.

4] DÓRIDE - Ó Galateia, nem me fales disso... Ainda há pouco o ouvimos cantar, quando te dedicou uma serenata... Valha-me Afrodite! Parecia um burro a zurrar. E que dizer da própria lira?! - A cabeça descarnada de um veado, os cornos a servirem de braços, ligados entre si, onde atou as cordas, sem serem esticadas por meio de cavilhas! E ele executava uma melodia desengraçada e dissonante, ele berrando uma coisa, e a lira soando outra coisa, de tal modo, que náo éramos capazes de suster o riso, ao ouvirmos aquela cantiga de amor. A própria [ninfa] Eco, apesar de muito tagarela, não se dignou responder àquele bramido, com vergonha de parecer imitar uma canção rude e ridícula.

5] Entretanto, o apaixonado trazia nos braços um ursinho de brinquedo, tão peludo como o dono. Ó Galateia, quem não te invejaria por teres um tal apaixonado?!

GALATEIA - Pois então, Dóride, mostra-nos lá o teu, certamente mais belo, melhor cantor e melhor executante de cítara.

DÓRIDE - Bem... náo tenho nenhum apaixonado nem me gabo de ser desejada... mas... uma figura como é o Ciclope, que tresanda a bodum — um autêntico bode — , que, segundo se diz, come carne crua e devora os estrangeiros que aportam [à sua ilha], conserva-o e corresponde-lhe sempre da mesma maneira. 


\section{Ciclope e Posídon}

1] CIClOPE - Ó meu pai, o que eu sofri com esse maldito desse estrangeiro, que, depois de me ter embriagado, me atacou enquanto dormia e me cegou!

POSÍDON - Ó Polifemo, quem é que se atreveu a fazer tal coisa?

CIClOPE - Ao princípio, dizia chamar-se Ninguém, mas, depois de se ter escapado, já fora do alcance de dardo, disse chamar-se Ulisses.

POSÍDON - Sei a quem te referes: trata-se do itacense, que regressava de Ílion. Mas como fez ele isso, uma vez que não é lá muito corajoso?

2] CICLOPE - Ao regressar da pastagem, apanhei bastantes deles dentro da caverna, certamente cobiçosos das minhas ovelhas. Depois de ter colocado a tampa na entrada - tenho para esse fim uma pedra enorme - , e de ter feito uma fogueira com uma árvore que tinha trazido da montanha, apercebi-me de que eles tentavam esconder-se. Então eu apanhei uns quantos e, como é natural tratando-se de ladróes, devorei-os. Aí, esse malvado desse Ninguém, ou Ulisses, dá-me a beber uma droga qualquer, muito doce e perfumada, mas extremamente insidiosa e perturbadora. Logo depois de a ter bebido, pareceu-me que andava tudo à roda: a própria caverna estava virada ao contrário, e eu deixei de estar no meu perfeito juízo. Por fim, mergulhei no sono. Então ele aguçou um tronco, pô-lo em brasa e cegou-me enquanto eu dormia. Desde então, Posídon, fiquei cego.

3] POSÍDON - Como adormeceste profundamente, meu filho, a ponto de náo teres saltado enquanto te cegavam! Mas então como é que Ulisses conseguiu fugir? Estou certo de que não era capaz de deslocar a pedra da entrada.

CICLOPE - Fui eu que a retirei, para mais facilmente poder apanhá-lo à saída; sentado junto à porta, ali fiquei de máos estendidas, a apalpar, só deixando sair as ovelhas para a pastagem, tendo deixado entregue ao carneiro o que devia fazer no meu lugar. 
4] POSídon - Estou vendo: sem tu dares por isso, os homens escaparam-se por debaixo das ovelhas. Mas devias ter chamado os outros ciclopes em teu socorro.

CIClOPE - Eu chamei-os, meu pai, e eles acorreram; mas, quando me perguntaram o nome de quem me tinha feito mal e eu lhes disse «Ninguém», julgaram que eu estava louco, pelo que se retiraram. Foi assim, com o seu nome, que o maldito me enganou. Mas o que mais me aborreceu foi ter dito, ao mesmo tempo que me lançava à cara a minha desgraça: «Nem Posidon, teu pai, te curará.»

POSÍDON - Anima-te, meu filho, pois eu vingar-me-ei dele, que é para saber que, se me é impossível curar a perda da vista, já o que respeita aos navegantes - salvá-los ou aniquilá-los — está sob a minha alçada. E ele ainda anda no mar... 


\section{Posídon e Alfeu ${ }^{96}$}

1] POsíDON — Que é isto, ó Alfeu? És o único, entre todos, que te lanças no mar sem te misturares com a água salgada, como acontece com todos os rios, nem descansas depois de desaguar, mas, pelo contrário, prosseguindo através do mar e conservando a tua corrente de água doce, precipitas-te sem mistura e puro, mergulhando fundo, sabe-se lá para onde, tal qual as gaivotas ou os alcatrazes; depois, parece que emerges de qualquer lado e voltas a aparecer.

ALFEU - Ó Posídon, trata-se de um caso de amor. Portanto, não me censures. Tu próprio já te apaixonaste muitas vezes.

POSÍDON — Mas, ó Alfeu, estás apaixonado por uma mulher, por uma ninfa ou por uma das Nereidas marinhas?

AlfEU - Nada disso, Posídon: é por uma fonte.

POSÍDON - E em que parte da terra é que ela corre?

ALFEU - Numa ilha... na Sicília. Chama-se Aretusa.

2] POsídon - Conheço-a bem, ó Alfeu, essa Aretusa. Não é nada feia e, além disso, é límpida, brota de uma nascente pura, e a sua água brilha sobre os seixos, que dão a toda ela um tom prateado.

AlfEU - De facto, Posídon, tu conheces essa fonte. Bem... vou ter com ela.

POSÍDON - Pois então, vai lá, e que tenhas sorte no amor. Mas... diz-me cá uma coisa: Onde é que viste Aretusa, sendo tu da Arcádia, e ela de Siracusa?

ALFEU - Ó Posídon, estou com pressa, e tu estás a atrasar-me com perguntas indiscretas.

POSÍDON - Dizes bem. Pois corre para junto da tua amada e, emergindo do mar, mistura-te com essa fonte e tornai-vos uma só [corrente de] água.

\footnotetext{
${ }^{96}$ Rio da Arcádia e da Élide, aqui personificado.
} 
(Página deixada propositadamente em branco) 


\section{Menelau e Proteu}

1] Menelau - Que tu, Proteu, te transformes em água, não tem nada de incrível, pois és um ser marinho; em árvore, ainda admito; e até mesmo que te transfigures em leão... nada disso está fora do que é crível. Mas que tu, habitante do mar, sejas capaz de te transformar em fogo, é coisa que muito me espanta e me faz duvidar.

PROTEU - Não te espantes, Menelau: transformo-me mesmo.

MENELAU — Sim, eu próprio vi [com os meus olhos]... No entanto — permite-me que te diga — dá a impressão de que metes ilusionismo na coisa e assim ludibrias os olhos de quem assiste, sem que realmente te transformes nessas coisas.

2] PROTEU - Mas que ludíbrio poderia haver em coisas tão evidentes? Não assististe de olhos bem abertos a tudo em que eu me metamorfoseei? Se não acreditas, se te parece coisa falsa e fantasia aquilo que está diante dos teus olhos, então, meu caro, toca-me com a tua máo, quando eu me transformar em fogo, e logo ficarás a saber se eu só tenho essa aparência, ou se tenho mesmo o poder de queimar.

MENELAU — A experiência, Proteu, não deixa de ser perigosa.

PROTEU - Ó Menelau, até parece que nunca viste um polvo, nem sabes o que acontece com este [tipo de] peixe ${ }^{97}$.

MENELAU - Claro que já vi um polvo, mas gostaria de saber da tua boca o que acontece com ele.

3] PROTEU - Quando o polvo aplica as ventosas a uma rocha qualquer e se pega fortemente a ela com os tentáculos, fica semelhante a essa rocha e modifica a própria cor, imitando a [cor da] rocha, a fim de passar despercebido aos pescadores, não se diferençando, assim, nem se deixando assinalar, por se confundir com a rocha.

MENELAU - É o que se diz. Mas o teu caso, Proteu, é muito mais incrível.

PROTEU — Já não sei, Menelau, em que outra coisa tu poderias acreditar, já que duvidas dos teus próprios olhos.

MENELAU — Sim, eu vi, mas trata-se de algo muito estranho: a mesma pessoa ser fogo e ser água.

\footnotetext{
97 Também para os gregos, «tudo o que vem à rede...».
} 
(Página deixada propositadamente em branco) 


\section{Posídon E OS Golfinhos}

1] POSÍDON - Acho muito bem, golfinhos, que sejais amigos dos homens. Há muito tempo, recolhestes e transportastes até ao Istmo o filho de Ino, que tinha caído da falésia de Círon, juntamente com sua mãe. Ainda agora, tu aí, tomaste sobre ti o citaredo de Metimna ${ }^{98}$ e depuseste-o no [cabo] Ténaro, com o seu vestuário próprio e com a cítara, não permitindo que ele fosse ingloriamente assassinado pelos marinheiros.

GOLFINHOS - Não te admires, Posídon, por nós fazermos bem aos homens, pois nós próprios fomos transformados de homens em peixes.

POSíDON - Realmente ${ }^{99}$, censuro Dioniso pelo facto de, depois de vos ter vencido numa batalha naval, vos ter metamorfoseado, quando bastava fazer-vos prisioneiros, tal como submeteu outros. Mas então, ó Golfinho, como é que foi esse episódio passado com Aríon?

2] GOLFINHOS - Periandro, segundo parece, gostava muito de Aríon, a quem mandava chamar, devido ao seu virtuosismo. Ora, tendo ele feito fortuna graças ao tirano, decidiu regressar à sua pátria, a Metimna, para aí exibir a sua riqueza, pelo que embarcou num navio pertencente a uns facínoras. Então, tendo revelado que levava consigo muito ouro e prata, os tripulantes, a meio do mar Egeu, conspiraram contra ele. Nesse momento - eu ouvi tudo, pois nadava junto do navio - Aríon disse: "Já que assim decidistes, pelo menos deixai-me envergar as vestes adequadas, entoar um canto fúnebre por mim mesmo e lançar-me voluntariamente [ao mar].» Os marinheiros acederam [ao seu pedido], e ele envergou o vestuário próprio, entoou um canto muito melodioso e lançou-se ao mar, na intenção de ter uma morte rápida. Entấo eu, aparei-o, carreguei-o no lombo e, mantendo-o nessa posição, fi-lo desembarcar no [cabo] Ténaro.

POSíDON - Louvo o teu amor pela música. Na verdade, retribuíste-lhe condignamente pelo concerto.

${ }^{98}$ Referência a Aríon, natural de Metimna, cidade de Lesbos.

99 Alguns mss. e editores modernos (Loeb...) incluem o período de Realmente até outros na fala anterior, só fazendo entrar a fala de Posídon desde Mas então até Aríon. Entendi seguir outra interpretação (K. Mras...). Naturalmente, cada uma das opçóes implica pequenas alteraçóes (vos/nos). 
(Página deixada propositadamente em branco) 


\section{Posídon, [Anfitrite] E as Nereidas [9]}

1] POSÍDON - Que este estreito, onde a jovem se precipitou, seja denominado Helesponto, do seu nome. E vós, Nereidas, pegai no seu cadáver e levai-o para a Tróade, a fim de ser sepultado pela gente dessa terra.

ANFITRITE - De maneira nenhuma, Posídon: é preferível que ela seja sepultada no mar que tem o seu nome. Na verdade, lamentamo-la por ter sido tấo miseravelmente tratada pela madrasta.

POSÍDON - Isso não seria legítimo, Anfitrite. Aliás, não seria decente que ela jazesse por aqui, sob o areal, mas, pelo contrário, como eu já disse, devia ser sepultada na Tróade ou no Quersoneso. Seria para ela um grande motivo de consolaçáo o facto de, dentro de pouco tempo, vir a acontecer o mesmo a Ino, a qual, perseguida por Atamante, se lançará, com o filho nos braços, do cabo de Citéron ao abismo, no sítio onde [este cabo] desce abruptamente sobre o mar. Mas vamos ter de salvar Ino, a fim de agradar a Dioniso, de quem ela foi ama-de-leite.

2] ANFitrite — Não devia ser assim, má como ela é.

POsídON - Mas também, ó Anfitrite, não é justo desagradar a Dioniso.

NEREIDAS - Afinal, como é que Hele caiu do carneiro abaixo, ao passo que seu irmáo Frixo prosseguiu caminho em segurança?

POSÍDON - É muito simples. De facto, enquanto ele é um jovem capaz de resistir à impetuosidade [do carneiro], ela, sem ter a devida experiência, galopou numa montada nada habitual. Então, olhando para o imenso vazio lá em baixo, ficou aterrorizada e, ao mesmo tempo, maravilhada ${ }^{100}$; enjoada pela rapidez do voo, largou os cornos do carneiro, aos quais até aí se tinha mantido agarrada, e precipitou-se no mar.

NEREIDAS - Mas... não deveria sua mãe, Néfele, prestar-lhe socorro na queda?

POSÍDON — Pois devia... mas a Moira é mais poderosa que Néfele.

${ }^{100}$ Segui a lição $\theta \alpha ́ \mu \beta \varepsilon \imath$. Muitos editores (K. Mras, Loeb...) preferem a lição $\theta \alpha ́ \alpha \lambda \varepsilon \imath$, que daria o sentido de «cheia de calor»... 
(Página deixada propositadamente em branco) 


\section{PÂNOPE E GaLENE ${ }^{101}$ [5]}

1] PÂNOPE - Ó Galene, viste o que é que Éride ${ }^{102} \mathrm{fez}$ ontem na Tessália, durante o jantar, pelo facto de não ter sido convidada para o banquete?

GALENE - Não estive presente no vosso banquete; na verdade, Pânope, Posídon tinha-me ordenado que, a essa hora, cuidasse da tranquilidade do mar. Mas entáo que é que fez Éride, por não ter sido convidada?

PÂNOPE - Tétis e Peleu já se haviam retirado para os seus aposentos, acompanhados por Anfitrite e Posídon, quando Éride, passando despercebida de todos (coisa fácil, pois uns bebiam, e outros aplaudiam ou estavam atentos, escutando Apolo a tocar cítara ou as Musas a cantar), arremessou para o meio da sala uma maçã magnífica, de oiro maciço, na qual estava uma inscrição que dizia: PARA A MAIS BELA. A maçã foi rolando e, como se de propósito, foi parar ao sítio onde estavam reclinadas Hera, Afrodite e Atena.

2] Então Hermes apanhou a maçã e leu a inscrição, e nós, Nereidas, ficámos muito caladinhas. Sim, que outra coisa poderíamos nós fazer, perante aquelas grandes senhoras? Cada uma delas reclamava que a maçã lhe pertencia de direito, e a discussão teria chegado a vias de facto, se Zeus náo as tivesse apartado. Então ele disse: "Eu, pessoalmente, não emitirei juízo sobre essa demanda (de facto, elas queriam que fosse ele a julgar), mas descei até ao [monte] Ida, até junto do filho de Príamo, o qual, apreciador como é da beleza, saberá sentenciar qual é mais bela e certamente não vos julgará mal.»

GALENE - E que é que as deusas fizeram?

PÂNOPE - Hoje mesmo, creio eu, partem para o Ida, e dentro de pouco tempo virá alguém anunciar-nos quem foi a vencedora.

GALENE - Mas eu digo-te já: nenhuma das outras vencerá a combativo Afrodite... a menos que o árbitro seja curto de vista.

101 Duas Nereidas.

102 Personificação da discórdia: Discórdia. 
(Página deixada propositadamente em branco) 


\section{Tritáo, [Amimone ${ }^{103}$ ] e Posídon [6]}

1] TRITÃo - Todos os dias, Posídon, vai buscar água à fonte de Lerna uma jovem... coisinha deveras formosa. Eu, pelo menos, não me lembro de ter visto rapariga mais bela.

POSÍDON - Mas, ó Tritão, referes-te a uma jovem livre, ou é alguma serva encarregada de transportar água?

TRITÃO - Não é serva, mas sim filha desse tal Egípcio ${ }^{104}$, uma das cinquenta [Danaides], chamada Amimone. Na verdade, eu informei-me do seu nome e da sua família. Ora Dánao trata com muita severidade as filhas, acostuma-as a trabalhar duramente, manda-as carregar água e, entre outras coisas mais, educa-as para que não sejam preguiçosas.

2] POSíDON - E ela faz sozinha uma caminhada tão longa de Argos a Lerna?

TRITÃo - Sozinha, sim. Além disso, como sabes, Argos é uma região muito árida, pelo que é preciso transportar água para lá.

POSÍDON - Ó Tritão, tu perturbaste-me, e não foi pouco, falando-me dessa jovem. Portanto, vamos até ela.

TRITÃO - Vamos, pois está na hora de ela carregar água. Já deve estar mais ou menos a meio do caminho para Lerna.

POSÍDON — Pois então aparelha o carro... ou então, já que é uma operaçáo demorada atrelar os cavalos ao jugo e preparar o carro, arranja-me tu mesmo um dos golfinhos mais rápidos, pois, montado nele, chegarei lá mais depressa.

TRITÃO - Aqui está o mais veloz dos golfinhos.

POSÍDON - Muito bem, partamos. E tu, Tritão, vai nadando ao nosso lado; e logo que cheguemos a Lerna, eu ficarei de emboscada em qualquer sítio, enquanto tu observas... e logo que a vires chegar...

TRITÃO — Ei-la já bem perto.

3] POSíDON - Ó Tritão, que moça tão bela e tão perfeita! Temos de raptá-la.

${ }^{103}$ Danaide amada por Posídon. Como a Argólida era muito seca, Posídon fez nascer uma fonte naquela região. Alguns editores náo a incluem no título.

${ }^{104} \mathrm{O}$ seu nome, como se vê a seguir, é Dánao. 
AMIMONE - Ó homem, porque me raptas e para onde me levas? És mesmo um raptor de gente livre... Parece-me que foste enviado pelo meu tio Egipto. Vou gritar pelo meu pai.

TRITÃO - Cala-te, Amimone, pois trata-se de Posídon.

AMIMONE - Qual Posídon?! Ó homem, porque me violentas e me arrastas para o mar? Infeliz de mim, que irei ao fundo e morrerei afogada.

POSÍDON - Anima-te, nada de mal te acontecerá. Mas antes, batendo com o tridente na rocha junto à praia, farei brotar neste sítio uma fonte com o teu nome, e tu ficarás feliz e, além disso, serás a única de entre as tuas irmãs que, depois de morta, nấo carregará água. 


\section{9. ÍRIS E PosíDON [10]}

1] ÍRIS - Ó Posídon, aquela ilha errante, que se separou da Sicília e ainda vagueia por sob as águas, essa, Zeus ordena-te que a faças parar imediatamente, a tragas à superfície e faças que ela, bem visível ${ }^{105}$ em pleno mar Egeu, fique aí muito bem firme, pois ele tem necessidade dessa ilha.

POSÍDON - Será feita a sua vontade, Íris. Mas que utilidade lhe proporcionará ela pelo facto de estar emersa e deixar de navegar?

ÍRIS - É que Latona deve ir dar à luz nessa ilha, e até já está com terríveis dores de parto.

POSÍDON - O quê? Então o céu não bastante grande para ela aí dar à luz? Ou, à falta deste, não pode toda a terra receber os filhos de Latona?

ÍRIS - Não, Posídon. Na verdade, Hera obrigou a Terra, sob juramento solene, a não dar hospitalidade a Latona em trabalhos de parto. Ora, esta ilha está fora do juramento, pois não era visível.

2] POSíDON - Compreendo. Ó ilha, emerge novamente do abismo e não te mexas daí, mas permanece bem fixa e acolhe, ó bem-aventurada, os dois filhos de meu irmáo, os mais formosos de entre os deuses. E vós, Tritōes, transportai Latona a esta ilha, e que o mar esteja calmo. E quanto à serpente que a atormenta e aterroriza, logo que estes seus filhos nascerem, atacá-la-ão e vingarão a mãe. E tu, Íris, vai anunciar a Zeus que está tudo preparado: Delos está fixa. Que venha já Latona e que dê à luz.

${ }^{105}$ Jogo de palavras intraduzível: $\delta \hat{\eta} \lambda$ o «visível» e $\Delta \hat{\eta} \lambda$ o «(ilha de) Delos». Luciano parece recolher uma variante da lenda, que não se encontra em mais nenhuma fonte de informação. 
(Página deixada propositadamente em branco) 


\section{Xanto E O MAR [11]}

1] XANTO - Ó Mar, acode-me, que estou a sofrer horrivelmente: apaga-me este fogo ardente.

MAR - Que é que foi, ó Xanto? Quem te pegou fogo?

XANTO - Foi Hefesto. Desgraçado de mim, que fiquei em brasa e todo a ferver.

MAR - Mas porque é que ele te lançou fogo?

XANTO - Foi por causa do filho de Tétis. De facto, estando ele a massacrar os Frígios, por muito que eu lhe suplicasse, não punha termo à sua cólera, mas atravancava-me a corrente com os cadáveres. Aí eu, apiedando-me dos infelizes, lancei-me sobre ele, na intençáo de o submergir e de o obrigar, por medo, a deixar esses homens.

2] Então Hefesto, que por acaso estava ali perto, carregou e atirou contra mim todo o fogo - julgo eu - que tinha na forja e quanto havia no Etna, esturrou-me os choupos e os tamariscos, grelhou-me os pobres peixes e enguias, e a mim próprio fez-me transbordar, pouco faltando para me deixar completamente seco. Estás a ver em que estado eu fiquei com aquelas queimaduras.

MAR - É natural, Xanto, que estejas turvado e a ferver: turvado, devido ao sangue dos mortos, e a ferver, devido, como dizes, ao fogo. E foi bem feito, ó Xanto, por te teres atirado contra o meu neto e sem respeito pelo filho de uma Nereida.

XANTO - Então eu não devia compadecer-me dos meus vizinhos Frígios?

MAR - E também não devia Hefesto compadecer-se de Aquiles, filho de Tétis? 
(Página deixada propositadamente em branco) 


\section{Noto E ZÉFIRo}

1] NOTO - Ó Zéfiro, esta novilha, que Hermes conduz através do mar até ao Egipto, foi mesmo desflorada por Zeus, tomado de paixão por ela?

ZÉFIRO - Sim, Noto, mas nesse tempo ela não era uma novilha, mas sim filha do rio Ínaco. Agora, porém, Hera metamorfoseou-a assim, ciumenta por ver que Zeus estava completamente apaixonado por ela.

NOTO - Será que Zeus ainda está apaixonado por ela como vaca?

ZÉFIRO - Claro que sim, e foi por esse motivo que ele a mandou para o Egipto e nos ordenou que não agitássemos as ondas do mar, até que ela fizesse a travessia, pois dará aí à luz — até já está grávida —, e será feita deusas, bem como o menino.

2] NOTO - A novilha... uma deusa?

ZÉFIRO - Claro, Noto. E mais: segundo me disse Hermes, mandará nos navegantes e será a nossa patroa, escolhendo qual de nós ela quer enviar [a qualquer parte] ou impedir de soprar.

NOTO - Portanto, temos de tratá-la bem, Zéfiro, já que é a nossa patroa. Deste modo, ser-nos-á mais propícia. ${ }^{106}$

ZÉFIRO - Mas eis que terminou a travessia e já pôs pé em terra. Estás a ver como já não caminha a quatro patas? De facto, Hermes endireitou-a e transformou-a novamente numa mulher formosíssima.

NOTO - Mas que coisa incrível, ó Zéfiro! Já não tem cornos, nem cauda, nem patas fendidas, mas agora é uma moça amorosa. E que é que se passa com Hermes, que também está transformado? Em vez de jovem, ficou com cabeça de cão ${ }^{107}$.

ZÉFIRO - Não sejamos indiscretos, pois ele sabe melhor do que nós o que tem a fazer.

106 Para alguns editores atribuem o último período à fala seguinte, de Zéfiro.

107 Trata-se do deus egípcio Anúbis, que os Gregos identificavam com Hermes. 
(Página deixada propositadamente em branco) 


\section{DÓRIDE ${ }^{108}$ E TÉTIS}

\section{1] DÓRIDE - Porque choras, Tétis?}

TÉTIS - É que, ó Dóride, vi uma jovem formosíssima encerrada por seu pai numa caixa — ela e o seu bebé recém-nascido. O pai ordenou a uns marinheiros que levassem a caixa e, quando já estivessem muito afastados de terra, a lançassem ao mar, para que a desgraçada morresse - ela mais o bebé.

DÓRIDE - E porquê, minha irmã? Conta-me cá tudo em pormenor, se é que sabes ${ }^{109}$.

TÉTIS - Acrísio, seu pai, por ela ser táo formosa, encerrou-a numa câmara de bronze, a fim de lhe conservar a virgindade. Mais tarde... não posso dizer se é verdade, mas diz-se que Zeus, sob a forma de [chuvisco de] ouro, escorregou através do telhado até junto da jovem, e que esta, tendo recebido no seu seio o deus escorrente, ficou grávida. Então seu pai, um velho cruel e ciumento, ao saber do caso, ficou furioso e, julgando que a moça tinha sido seduzida por algum homem, meteu-a nessa caixa, mal ela deu à luz.

2] DÓRIDE - E que é que ela fazia, ó Dóride, enquanto estavam a metê-la na caixa?

TÉTIS - Em sua defesa, Dóride, não dizia nada, pois submetia-se à condenação, mas suplicava que não matassem o bebé, chorando e mostrando ao avô o menino, que era formosíssimo e que, na sua ignorância, sorria para o mar. Até fico com os olhos rasos de água, só de me lembrar.

DÓRIDE - E fizeste-me chorar também a mim. Mas será que eles já estão mortos?

TÉTIS - Nada disso: a caixa ainda flutua ao largo da ilha de Sérifo, mantendo-os vivos.

DÓRIDE - Então porque não os salvamos e os atiramos para as redes dos pescadores de Sérifo? Estes, ao recolherem as redes, certamente os salvarão.

TÉTIS - Dizes bem, façamos assim, para que não morram, nem ela nem uma criança tão formosa.

${ }^{108}$ Dóride (Dóris), filha de Oceano e irmã de Tétis, desposou seu irmão Nereu, de quem teve 50 filhas, as Nereidas.

109 Aqui segui a edição de K. Mras. 
(Página deixada propositadamente em branco) 


\section{Enipeu E Posídon}

1] ENIPEU — Ó Posídon, para dizer a verdade, isto não está certo: tomaste a minha figura, introduziste-te junto da minha amada e desvirgaste a jovem. Esta julgava que era eu a fazer a coisa, e por isso entregou-se.

POSÍDON - É que tu, Enipeu, mostravas-te muito sobranceiro e indiferente: desdenhavas de uma jovem assim tấo bela, que todos os dias te procurava, morta de amor por ti, e gostavas de afligi-la. Ela deambulava pelas tuas margens, por vezes entrava e tomava banho nas tuas águas, ansiava por ter relaçóes contigo, mas tu desprezava-la.

2] ENIPEU - E daí? Lá por isso já te achas no direito de te apressares a roubar o objecto do meu amor, de fingires que eras Enipeu, em vez de Posídon, e de iludir uma jovem tão ingénua como é Tiro?

POSÍDON - Ó Enipeu, os teus ciúmes já vêm tarde, depois de tanta sobranceria. Aliás, Tiro não sofreu a mínima desonra, pois cuidou que tinha sido desvirgada por ti.

ENIPEU - Nada disso, pois tu, ao retirares-te, disseste que eras Posídon, o que muito a desgostou. Eu é que fiquei lesado, já que tu gozaste do que era meu e, envolto numa onda cerúlea que vos encobria, tiveste, no meu lugar, relaçóes com a jovem.

POSÍDON - Pois tive. Afinal, Enipeu, tu não querias. 
(Página deixada propositadamente em branco) 


\section{Tritão e as Nereidas}

1] TRITÃo - Esse vosso monstro, ó Nereidas, que vós enviastes contra a filha de Cefeu, não só não fez qualquer mal à jovem, como vós imaginais, mas quem morreu foi ele.

NEREIDAS - Às mãos de quem, ó Tritão? Será que Cefeu, usou a jovem como engodo e, tendo-se posto de emboscada com uma hoste numerosa, o atacou e matou?

TRITÁO - Nada disso. Creio que tu, Ifianassa, conheces Perseu, filho de Dánae e que, mandado lançar ao mar, dentro de uma caixa e juntamente com sua mãe, vós salvastes, por terdes piedade de ambos.

IFIANASSA - Sei a quem te referes. É natural que já seja um jovem valente e formoso de se ver.

TRITÁO - Foi esse que matou o monstro.

IFIANASSA - E porque fez ele isso? $\mathrm{Na}$ verdade, ele náo devia dar-nos uma tal paga por o termos salvo.

2] Tritấ - Vou contar-vos como tudo se passou. Este Perseu fora mandado contra as Górgonas, a fim de realizar uma tarefa por ordem do rei ${ }^{110}$. Ora, ao chegar à Líbia...

IFIANASSA - Como foi isso, ó Tritão? Foi sozinho, ou levou quem o ajudasse? Realmente, o caminho é muito penoso.

TRITÃO - Ele fez a viagem pelo ar, pois Atena fê-lo alado. Ao chegar ao local onde elas viviam, elas, segundo creio, estavam a dormir, e entáo ele cortou a cabeça da Medusa e partiu dali voando.

IFIANASSA - E como é que ele a viu? Na verdade, elas não se deixam ver, ou então, se alguém olha para elas, nunca mais vê mais nada depois disso.

TRITÃO - Atena facultou-lhe o seu escudo - de facto, ouvi-o contar estes factos a Andrómeda e, posteriormente, a Cefeu - ... Atena, como ia dizendo, proporcionou-lhe a maneira de ver a imagem da Medusa no escudo bem polido, como num espelho. Então Perseu, agarrando-lhe os cabelos com a máo esquerda e olhando para a imagem, pegou na cimitarra com a máo direita, cortou-lhe a cabeça e levantou voo, antes que as irmãs acordassem.

${ }^{110}$ Polidectes, rei de Sérifo (ilha do mar Egeu). 
3] Depois, ao chegar aqui às costas da Etiópia, e voando já mais baixo, avista Andrómeda, que jazia amarrada a um rochedo alcantilado, formosíssima, ó deuses, de cabelos soltos e seminua muito abaixo dos seios. Logo de início, compadecido da sua sorte, perguntou-lhe o motiva da condenação, mas, um pouco depois, dominado pela paixão... mas havia primeiro que salvar a jovem, decidiu socorrê-la. Assim, logo que surgiu o monstro deveras pavoroso que vinha devorar Andrómeda, o jovem elevou-se no ar de cimitarra em riste numa das máos, com que ataca, e, exibindo na outra mão a Górgona, transforma em pedra o monstro, bem morto, ao mesmo tempo que ficou petrificada a maior parte do seu corpo - aquela que esteve virada para a Medusa. Então Perseu desatou as cadeias da jovem e, dando-lhe a mão, amparou-a, enquanto ela, nas pontas dos pés, descia do rochedo, que era muito escorregadio. E vai já casar com ela no palácio de Cefeu, e depois há-de levá-la para Argos... e foi assim que a jovem, em vez da morte, conseguiu um casamento nada habitual.

4] IFIANASSA — Pela minha parte, não fico aborrecida com o [feliz] desenlace. Sim, em que é que a rapariga nos ofendia, lá porque sua mãe se gabava e pretendia ser mais bela que nós? DÓRIDE - É que, desse modo, a mãe, pelo facto de ser mãe, sofria pela filha.

IFIANASSA - Não recordemos isso, Dóride, quer dizer, o facto de uma mulher bárbara ter falado mais do que convinha. De facto, já foi bem castigada, ao temer pela sorte da filha. Portanto, congratulemo-nos com o seu casamento. 


\section{ZÉFIRo E Noto}

1] ZÉFIRO - Desde que me conheço e sopro, nunca assisti a uma procissão no mar mais magnífica que esta. Tu não viste, ó Noto?

NOTO - A que procissão te referes, ó Zéfiro? E quem eram os participantes?

ZÉFIRO - Perdeste um espectáculo muitíssimo agradável, como não verás mais nenhum outro.

NOTO - É que eu tinha que fazer na regiáo do Mar Vermelho e soprava sobre a parte do [oceano] Índico junto à costa. Por isso, não sei a que te referes.

ZÉFIRO - Ora bem: conheces Agenor de Sídon?

NOTO - Sim, é o pai de Europa. E então?

ZÉFIRO - É precisamente sobre ela que te vou falar.

NOTO - Porventura [vais contar-me] que Zeus está, desde há muito, apaixonado por essa jovem? Já sabia desse caso há muito tempo.

ZÉFIRO - Portanto, já conheces o amor existente entre eles. Mas escuta o que se passou a seguir.

2] Europa, brincando com as suas companheiras, tinha descido à praia, quando Zeus se pôs a brincar com elas, sob a forma de um touro de formosíssima aparência, pois era completamente alvo, com cornos recurvados e olhar doce. Começou também a saltar na praia e a mugir ternamente, de tal modo que Europa se atreveu a montá-lo. Mal isso aconteceu, Zeus lançou-se numa correria em direcção do mar, levando sobre o lombo; depois, entrando na água, avançou a nado; a jovem, completamente aterrorizada com o caso, agarrava-se com a mão esquerda a um corno, a fim de não escorregar, enquanto, com a outra máo, segurava o vestido contra o vento.

3] Noto - Ó Zéfiro, esse espectáculo a que tu assististe foi muito agradável e muito erótico: Zeus transportando a nado a sua amada.

ZÉFIRO - Sim, ó Noto, mas o que se passou a seguir é ainda mais agradável. Na verdade, o mar ficou imediatamente sem ondas e, ganhando um aspecto calmo, apresentava-se muito liso. Todos nós, [os ventos,] sem termos nada que fazer, limitávamo-nos a acompanhar os acontecimentos como simples 
espectadores, enquanto os Amores, esvoaçando um pouco acima da superfície do mar, a ponto de algumas vezes tocarem na água com as pontas dos pés, e empunhando fachos acesos, cantavam e entoavam o hino do casamento; e as Nereidas, emergiam das águas cavalgando golfinhos, batendo palmas e quase todas nuas; e a raça dos Tritóes e todos os outros seres marinhos de aspecto nada aterrorizador dançavam à volta da jovem; Posídon, de cima do seu carro e tendo a seu lado Anfitrite, seguia na frente, todo feliz por acompanhar seu irmão que nadava. Enfim, na cauda do cortejo, seguia Afrodite, transportada por dois Tritóes, reclinada numa concha e espalhando toda a espécie de flores sobre a noiva.

4] Este cortejo realizou-se desde a Fenícia até Creta. Logo que desembarcou nesta ilha, o touro deixou essa forma, e Zeus, tomando Europa pela máo, levou-a para a caverna do [monte] Dicteu, ruborizada e de olhos no chão, pois agora já sabia com que intenção fora raptada. Então nós lançámo-nos, cada um para sua parte do mar, a fim de levantarmos as ondas.

NOTO - Feliz de ti, Zéfiro, que assististe a um tal espectáculo! E eu que só via grifos, elefantes e homens negros! 


\section{DIÁLOGOS DOS MORTOS}


Texto da ed. de Karl Mras, Die Hauptwerke des Lukian 


\section{INTRODUÇÃO}

\section{Os Diálogos}

Talvez os mais lidos, comentados e até imitados dos seus escritos sejam os Diálogos: Diálogos dos Mortos, Diálogos dos Deuses, Diálogos dos Deuses Marinhos e Diálogos das Cortesás. Trata-se de quadros dramáticos, geralmente breves, em que várias personagens debatem um problema ou uma situação mais ou menos polémica ou censurável, num estilo a que hoje chamaríamos «revisteiro» (até na representaçáo possível), mas nem por isso, no seu conjunto, menos profundo. Nos Diálogos, Luciano critica sobretudo a mitologia tradicional, a ética dos deuses, mas também os comportamentos humanos.

Os Diálogos dos Deuses e os Diálogos dos Deuses Marinhos baseiam-se sobretudo na mitologia e na literatura sua transmissora (Homero, Hesíodo...): Luciano ataca os aspectos mais incríveis e mais irracionais dessas historietas.

No que diz respeito aos Diálogos das Cortesãs, trata-se de uma obra importante do ponto de vista da análise social de uma parte da sociedade ateniense do séc. II d.C. Enquanto os outros Diálogos a que atrás nos referimos se inspiram em histórias mitológicas ou na vida de mortos famosos (Sócrates, Filipe, Alexandre, Diógenes, Menipo, etc.), os Diálogos das Cortesấs têm uma forte marca de actualidade, ainda que possamos entrever neles, também, certas personagens da chamada "Comédia Nova»: a cortesá, o jovem apaixonado e ciumento, o criado ou a criada, a mãe...

Embora a actividade de prostituta esteja bem documentada na época clássica (a toda a gente ocorre o nome de Aspásia, amante e "companheira» de Péricles), esta profissão conhece um forte desenvolvimento nos períodos helenístico e romano. Muitas vezes, era o modo mais prático de lutar contra a miséria. Naturalmente, entre as mulheres que viviam do aluguer do corpo, havia as "finas» e as... de esquina de rua ou de encruzilhada, aliás normalmente designadas de modo diferente: por um lado, as $\dot{\varepsilon} \tau \alpha \hat{\imath} \rho \alpha$, hetairai, "heteras» ou "cortesãs», que, à maneira das sua predecessoras da época clássica, pretendiam ser "companheiras» dos seus amantes, para o que sabiam proporcionar-lhes outros prazeres além dos da carne: dizia-se que 
os homens tinham as esposas legítimas para lhes darem filhos, e as heteras para divertimento; por outro lado, a prostituta... de esquina era designada por $\pi$ ó $v \eta \eta$, pórnê, "puta" "meretriz»,

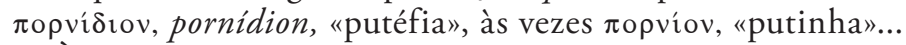

À profissão, tendencialmente rendosa, de "cortesã» estava muitas vezes associada a figura da mãe, especialmente da mãe viúva, que punha nos dotes físicos da filha a sua única esperança de não morrer de fome (v. 7: «Musário e sua mãe»).

Naturalmente, Luciano conhecia o ambiente, não apenas das leituras da Comédia Nova, mas, sobretudo, da vida real ateniense dos meados do séc. II d.C.; e embora a focagem esteja projectada principalmente sobre a cortesã, a mãe, uma amiga, a criada, etc., Luciano náo deixa de nos mostrar alguns exemplares de amantes (homens): os infiéis, os apaixonados, os chorões, os mãos-largas e os forretas, os pobretanas, os violentos... Em todo o caso, é importante notar que Luciano náo se mostra muito (ou nada!) crítico relativamente à prostituição, que ele devia ver como uma opção de vida por parte da mulher e como uma liberdade por parte do homem. Mais do que criticar, Luciano descreve diversos quadros da vida sexual e do comportamento do jovem e do homem casado do seu tempo. E que, para sermos curtos e breves, certas «instituiçôes», como a escravatura e a prostituição, estavam tão integradas na mentalidade das pessoas, que a ninguém ocorria sequer pô-las em causa.

\section{Os Diálogos dos Mortos}

De entre os Diálogos de Luciano (a que poderíamos acrescentar muitas outras obras igualmente em forma dramática), os Diálogos dos Mortos salientam-se nitidamente pela popularidade que ao longo dos séculos foram acumulando. Os leitores de Luciano recordam particularmente algumas dessas saborosas cenas, como, p. ex., a de Caronte e Menipo (D. M., 2): Caronte, o barqueiro dos Infernos, insiste desesperadamente com o filósofo cínico Menipo para que este lhe entregasse o óbolo - pagamento obrigatório, sem o qual os mortos não podem passar para o reino inferior. Ora, sucede que Menipo não tem com que pagar, pelo que só resta (só restaria!) uma solução: colocar na margem da vida o passageiro mau pagador... 
Fundamentalmente, são-nos apresentados mortos ilustres, quer à chegada ao reino de Hades, quer já de há longo tempo aí residentes. Naquele ambiente concentracionário, lúgubre e escuro, surgem alguns problemas, que envolvem não só os "hóspedes» entre si, mas também as divindades infernais. Deste modo, poderíamos dizer que se trata, de algum modo, também de diálogos dos deuses infernais, nas suas relações com os mortos à sua guarda.

Mais uma vez, Luciano aplica aqui a sua crítica acutilante, que não poupa nem as fraquezas humanas, nem alguns aspectos irracionais da mitologia. Entre as personagens destes diálogos salientam-se sobretudo, como representantes das ideias do próprio Luciano, as figuras dos filósofos cínicos Menipo e Diógenes, que entram em 16 dos 30 diálogos: 1 (Menipo indirectamente), 2, 3, 11 (Diógenes e o filósofo cínico Crates), 13, 16, 17, 18, 20, 21, 22, 24, 25, 26, 27 (Diógenes, Antístenes e Crates) e 28. A estes devemos acrescentar outras personagens, divinas ou humanas, como Agamémnon, Ájax, Alexandre, Aníbal, Antíloco, Aquiles, Cipião, Creso, Filipe, Mausolo, Midas, Nireu, Pitágoras, Protesilau, Sardanapalo, Sócrates, Sóstrato, Tântalo, Tersites, Tirésias; Caronte, Cérbero, Éaco, Héracles (Hércules), Hermes, Minos, Perséfone (Prosérpina), Pólux, Plutão, Quíron...

Umas quantas (poucas) personagens humanas podem ser fictícias ou não passam de "celebridades locais», mas, por isso mesmo, têm, mais do que valor histórico, um certo valor simbólico, como os parasitas Calidémides, Cnémon, Zenofanto, Térpsion, Damnipo... Mas as grandes figuras dos Diálogos dos Mortos são mesmo personagens da grande história: heróis homéricos, soberbos monarcas orientais, generais, filósofos e, é claro, algumas das principais divindades infernais.

Entre as personagens que merecem a simpatia de Luciano, contam-se os filósofos cínicos Diógenes e Menipo. De facto, a filosofia cínica, constituiu, na Antiguidade, o movimento mais corrosivo e mais crítico dos valores "universais», supostamente imutáveis, da sociedade «bem-pensante». Outra corrente filosófica que merece a admiração de Luciano (presente noutras obras, que não nesta) é o atomismo (Demócrito...), pela sua racionalidade contrária a todas as crenças infantis e cretinizantes.

Diógenes de Sinope, no Ponto Euxino, viveu no séc. IV a.C., em Atenas e Corinto. É o principal representante da filosofia 
Cínica, fundada em Atenas por Antístenes (n. 440 a.C.). Outros filósofos cínicos são Crates e Menipo. Na sua forma mais ou menos definitiva, a filosofia cínica tenta destruir os valores mais firmes, pretensamente universais, da sociedade tradicional «bem comportada». $\mathrm{Na}$ Antiguidade, contavam-se, a respeito de Diógenes, centenas de histórias, na sua maioria inventadas, mas, de qualquer forma, bem ilustrativas da personagem e das suas ideias. A designação de cínico deriva de Cinosarges, local a leste e nos arredores de Atenas, onde a escola funcionava.

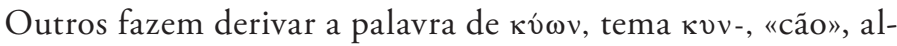
cunha dada a Diógenes... e a todos os outros (p. ex., Menipo: v. D. M., 21).

Menipo (séc. III a.C.) foi um notável filósofo desta mesma escola, cuja obra se perdeu, mas de que restam ecos noutros escritores. No diálogo no 1, Luciano, por intermédio de Diógenes, fornece-nos um bom retrato deste cínico. 
DIÁLOGOS DOS MORTOS 
(Página deixada propositadamente em branco) 


\section{Diógenes e PóluX ${ }^{\mathrm{III}}$}

1] Diógenes - Ó Pólux, recomendo-te, logo que chegues lá acima (creio que é já amanhã a tua vez de voltar à vida), se por acaso vires Menipo, o cáo (deves encontrá-lo em Corinto, lá para as bandas do Craneu, ou então no Liceu, fazendo troça dos filósofos em permanente discussão uns com os outros), que lhe dês este recado: "Ó Menipo, Diógenes convida-te, se já troçaste o bastante das misérias terrenas, a vir cá abaixo, para te rires muitissimo mais. Sim, que o teu riso, ai na terra, pode, de algum modo, ser injustificado, e muitas vezes se pergunta: 'Quem conhece completamente o que há para além da vida?', ao passo que, cá em baixo, não cessarás de rir com todo o fundamento, como eu agora, sobretudo ao veres os ricos, os sátrapas e os tiranos agora tão reles e tão insignificantes, só reconheciveis pelas suas lamentaçóes; vê como essas criaturas são frágeis e ignóbeis, a recordarem continuamente a sua vida terrena." Dá-lhe, pois, este recado. E mais: que venha com o saco bem atafulhado de tremoços bem como, caso o ache para aí nalguma encruzilhada, o jantar de Hécate ${ }^{112}$, ou então um ovo lustral, ou qualquer coisa do género.

2] PÓluX - Dar-lhe-ei o recado, Diógenes. Mas... para poder identificá-lo bem, que aspecto tem ele?

DIÓGENES - É velho, careca, com um manto cheio de buracos e exposto a todos os ventos, e muito garrido, tantos são os remendos feitos de andrajos; além disso, está sempre a rir e, a maior parte das vezes, a troçar desses filósofos charlatães.

PÓluX - Com esses dados, é fácil encontrá-lo.

DIÓGENES - Queres que eu faça alguma recomendação dirigida a esses tais filósofos?

111 Castor e Pólux, os Dioscuros "filhos de Zeus», gémeos dos mais famosos da mitologia. Sua mãe, Leda, esposa de Tíndaro, rei de Esparta, teve, na mesma noite, relaçóes com o marido e com Zeus, que lhe havia aparecido sob a forma de cisne. Dessa união nasceram Castor, filho de Tíndaro, e Pólux, filho de Zeus. Só este teria direito à mortalidade... mas as coisas compuseram-se, na medida do possível: cada um deles passaria, alternadamente, seis meses no Hades e seis meses no Olimpo. É a essa alternância que se refere o texto.

112 Hécate, deusa infernal, venerada nas encruzilhadas, protectora das bruxas, por vezes associada à Lua. Os mortos acalmavam a sua ira, levando-lhe o "jantar de Hécate», a que aqui se faz referência. 
PÓLUX — Então diz lá, pois não será muito custoso.

DIÓGENES - Em poucas palavras, recomenda-lhes que deixem de dizer asneiras, de discutir sobre todas as matérias, de porem cornos uns aos outros ${ }^{113}$, de fazerem crocodilos e de ensinarem os espíritos a fazerem perguntas insolúveis como estas.

PólUX - Mas... eles vão dizer que eu sou um ignorante, um estúpido, por atacar a sua sabedoria.

DIÓGENES - E tu diz-lhes que vão passear, que sou eu que mando.

PÓlUX — Também lhes darei esse recado, Diógenes.

3] Diógenes - Aos ricos, meu queridinho Pólux, dá-lhes este recado da minha parte: "Insensatos, porque guardais o vosso ouro? Porque vos atormentais a calcular os juros e a acumular talentos sobre talentos, vós, a quem basta trazer um só óbolo ${ }^{114}$, quando, em breve, vierdes para este lado?»

PÓLUX - Também esse recado lhes será transmitido.

DIÓGENES - E aos belos e robustos, por exemplo a Megilo de Corinto e a Damóxeno, o lutador, diz-lhes que cá entre nós já não há nem cabeleira loira, nem olhos azuis ou negros, nem faces coradas, nem músculos tensos, nem ombros fortes, mas, como sói dizer-se, tudo aqui é um só monte de pó e caveiras despojadas de toda a beleza.

PÓLUX - Também não é difícil transmitir esse recado aos belos e robustos.

4] DiÓGENES - E aos pobres, ó Lacónio ${ }^{115}$ (que são tantos, tão carregados de dificuldades e queixosos da sua miséria), diz-lhes que não chorem nem se lamentem, depois de tu lhes falares da igualdade que aqui reina e de lhes dizeres que eles próprios verificarão que aqueles que aí na terra eram ricos náo estão agora em melhor situação que eles. E quanto aos Lacedemónios, teus patrícios, faz o favor de os censurar e de lhes dizer que eles estáo completamente em decadência.

${ }^{113}$ Alude-se a um falso silogismo: $\boldsymbol{a}$ ) Tens o que não perdeste; $\boldsymbol{b}$ ) Não perdestes os cornos; $c$ ) Logo, tens cornos. A falácia do crocodilo era outra das armadilhas com que alguns "filósofos» maravilhavam e confundiam os simples.

114 Além do «jantar de Hécate» (v. supra), os mortos levavam uma moedinha de 1 óbolo, para pagarem a passagem (v. diálogo no 22).

${ }^{115}$ Castor e Pólux tinham nascido em Esparta, na Lacónia (v. nota supra). 
PÓlUX - Ó Diógenes, não digas nada a respeito dos Lacedemónios, que é coisa que eu năo vou admitir; todavia, o que tu disseste dirigido aos outros, isso eu transmitirei.

DIÓGENES - Pois deixemos esses em paz, já que assim o queres. Quanto àqueles que anteriormente referi, leva-lhes o recado da minha parte. 
(Página deixada propositadamente em branco) 


\section{Creso, Plutão ${ }^{116}$, Menipo, Midas e Sardanapalo}

1] CRESO - Ó Plutão, não suportamos aqui este cão deste Menipo que mora junto de nós. Assim, ou tu o colocas em qualquer outro lado, ou nós nos mudaremos para outro sítio.

PLUTÁO - Mas que mal vos faz ele, sendo um morto como vós?

CRESO - Sempre que nós nos lamentamos e gememos, lembrados das coisas lá de cima — aqui o Midas do seu oiro; Sardanapalo das suas muitas delícias; e eu, Creso, dos meus tesouros —, ele troça de nós e ofende-nos, chamando-nos escravos e merdosos; por vezes, chega mesmo a cantar, com o que perturba as nossas lamentaçóes. Numa palavra: é aflitivo.

PLUTÃo - Que é isto que eles estão dizendo, ó Menipo?

MENIPO - A verdade, Plutão. De facto, odeio-os, por serem ignóbeis e uns miseráveis, aos quais não bastou terem vivido de forma ignominiosa, mas, depois de mortos, ainda evocam a vida terrena e se apegam a ela. Por isso, apraz-me atormentá-los.

PLUTÃO - Mas não deve ser assim: realmente, eles sofrem, ao verem-se privados de bens nada desprezáveis.

MENIPO - Também tu endoideceste, ó Plutão, ao concordares com as lamentaçōes destes tipos?

2] PluTÃo - De maneira nenhuma... só que não quereria que vós brigásseis.

MENIPO - Seja como for, ó vós, as piores criaturas de entre os Lídios, os Frígios e os Assírios, ficai sabendo que não tenciono parar: sim, para onde quer que vades, seguir-vos-ei, atormentando-vos, cantando e rindo.

CRESO - Não é isto uma insolência?

MENIPO - Não, não é! Insolência era o que vós fazíeis, julgando-vos dignos de serdes adorados, fazendo pouco de homens livres e não vos lembrando absolutamente nada da morte. Por isso mesmo, lamentar-vos-eis, privados de todos esses bens.

CRESO - De quanta e enormes riquezas, ó deuses!

MIDAS - E eu, de quanto ouro!

SARDANAPALO — E eu, de quantas delícias!

${ }^{116}$ Plutão, ou Hades, o deus supremo do reino dos mortos. 
MENIPO - Muito bem! Continuai assim: vós lamentais-vos, e eu, repetindo vezes sem conto o "Conhece-te a ti mesmo", cantá-lo-ei para vós, pois será bem próprio de ser cantado a acompanhar as vossas lamentaçōes. 


\section{MENIPO E TROFÓNIO ${ }^{117}$}

1] MENIPO - Vós ambos, Trofónio ${ }^{118}$ e Anfíloco, não sei lá como é que, sendo mortos, fostes julgados dignos de terdes templos e de serdes considerados adivinhos... E os tolos dos homens acreditam que vós sois deuses.

TROFÓNIO - E que culpa temos nós que eles, na sua estupidez, acreditem numa tal coisa a respeito de mortos?

MENIPO - Mas não acreditariam, se vós, quando vivos, náo vos tivésseis dedicado a charlatanices, passando por pessoas capazes de prever e predizer o futuro dos vossos consulentes.

TROFÓNIO - O Menipo, aqui o Anfíloco saberá o que há-de responder a seu respeito, mas eu sou um herói e exerço a adivinhaçáo, se alguém vem procurar-me. Ora, parece que tu nunca por nunca estiveste em Lebadia ${ }^{119}$, pois, caso contrário, não duvidarias deste facto.

2] MENIPO — É o quê? Se eu não for a Lebadia e, ridiculamente envergando uma veste de linho e tendo nas mãos um pãozinho, náo penetrar de rastos pela entrada da gruta, que é muito baixa, náo poderei saber que tu estás morto, como nós, apenas com a diferença da tua charlatanice? Mas... pelo teu dom de adivinho, diz-me cá o que é isso de ser herói, que eu não sei.

TROFÓNIO - É um composto de uma parte de homem e uma parte de deus.

MENIPO - Um ser que, segundo dizes, não é nem homem nem deus, mas participa das duas naturezas? Mas, neste momento, para onde foi essa tua metade divina?

TROFÓNIO - Profere oráculos na Beócia, ó Menipo.

MENIPO - Não sei do que estás a falar, ó Trofónio, mas lá que estás completamente morto, isso vejo eu claramente.

${ }^{117}$ Alguns editores atribuem a 2a fala a Anfíloco, pelo que introduzem o seu nome no título: MENIPO, ANFíloco E TROFÓNIO.

118 Trofónio e Anfíloco, apesar de terem origem humana, ganharam tal fama como adivinhos, que foram assimilados a divindades. As dúvidas de Menipo são, pois, muito pertinentes. Curiosa é a justificação dada por Trofónio.

${ }^{119}$ Lebadia, cidade da Beócia. 
(Página deixada propositadamente em branco) 


\section{HeRme ${ }^{120}$ e CARONTE}

1] HERMES - Se estás de acordo, barqueiro, façamos a conta a quanto já me deves, para não voltarmos a discutir sobre esse assunto.

CARONTE - Façamos a conta, Hermes, pois é melhor e dá menos aborrecimentos que fique acertada.

HERMES - Uma âncora que me encomendaste: cinco dracmas.

CARONTE - É muito caro.

HERMES - Juro por Hades ${ }^{121}$ que a comprei por cinco dracmas... Mais uma correia para o remo: dois óbolos.

CARONTE - Aponta lá cinco dracmas e dois óbolos.

HERMES - Mais uma agulha de coser velas: custou-me cinco óbolos.

CARONTE - Aponta também isso.

HERMES - Mais cera para calafetar as fendas da barquinha... e pregos... e cordel com que fizeste o cabo da antena: ao todo, duas dracmas.

CARONTE - Muito bem! Fizeste uma boa compra.

HERMES - É tudo, se não me escapa nada na conta. E então quando tencionas pagar-me?

CARONTE - Ó Hermes, neste momento é impossível, mas, se uma peste ou uma guerra me mandarem por aí abaixo grandes quantidades de gente, entáo será possível obter lucro, especulando com o preço da passagem, à conta do grande número de pessoas.

2] HERMES - Então e eu vou ficar para aqui sentado, fazendo votos por que aconteçam essas desgraças, para delas retirar a minha paga?

CARONTE - Não há outra forma, Hermes; neste momento, como vês, chegam-nos poucos mortos, pois reina a paz.

HERMES - É melhor assim, ainda que se arraste a tua dívida para comigo. Em todo o caso, ó Caronte, sabes bem como os antigos se apresentavam, todos viris e, na sua maioria, cobertos de sangue e crivados de feridas. Agora, porém, lá aparece um ou outro que morreu envenenado pelo filho ou pela esposa, ou com o ventre e as pernas inchadas pelo deboche, todos eles pálidos e frágeis, nada parecidos com os de antanho. E na sua grande

${ }^{120}$ Hermes é o deus psicopompo, o "condutor de almas», que entrega os mortos a Caronte, o barqueiro do Inferno, que os passa para o outro lado.

${ }^{121}$ Hades ou Plutão, o deus supremo do reino dos mortos. 
maioria chegam cá, ao que parece, por conspirarem uns com os outros por motivos de dinheiro.

CARONTE - Realmente, o dinheiro é uma coisa muito apetecível.

HERMES - Justamente por isso, não deve parecer-te descabido que eu exija amargamente que me pagues o que me deves. 


\section{Plutão e Hermes}

1] Plutáo - Conheces aquele velho, quer dizer, mesmo muito velho, o ricaço Êcrates, que não tem filhos, mas cinquenta mil ${ }^{122}$ tipos à caça da sua herança?

HERMES - Sim, referes-te ao siciónio ${ }^{123}$. E então?

PLUTÃO - Esse mesmo, Hermes; deixa-o viver, para além dos noventa anos que já viveu e mede-lhe outros tantos anos de vida, se tal é possível, ou ainda mais; e quanto aos seus aduladores, o jovem Carino, Dâmon e os outros, arrasta-os todos de enfiada cá para baixo.

HERMES - Mas isso seria descabido.

PLUTÃo - Não seria, não, mas antes a coisa mais justa. Sim, porque é que esses tipos fazem votos por que o velho morra e cobiçam a sua fortuna, sem lhe pertencerem? Mas o mais repugnante de tudo é o facto de que, enquanto fazem tais votos, cuidam do velho, pelo menos em público, e, quando ele adoece, toda a gente se apercebe do que eles ficam a magicar, por muito que prometam fazer sacrifícios, caso ele se restabeleça. Enfim, a adulação desses homens assume aspectos variados. Por isso, que o velho seja imortal, e que os outros, frustrados nas suas expectativas, partam antes dele.

2] HERMES - Será um castigo de fazer rir, safados como eles são ${ }^{124}$. Mas olha que o velho também os leva à certa e lhes alimenta esperanças, mas ele, afinal, com aquele aspecto de estar sempre preste a morrer, tem mais saúde que os novos; entáo estes, com a herança já dividida entre eles, alimentam a cobiça, imaginando para si uma vida regalada.

PLUTÁO — Sendo assim, que o velho se dispa da velhice, tal como Iolau ${ }^{125}$, e rejuvenesça, enquanto aqueles, privados da sonhada riqueza, venham imediatamente para cá, esses miseráveis, mortos de morte miserável.

${ }^{122}$ Cinquenta mil é aquilo a que se chama «numeração indeterminada»; traduzi à letra, mas também podiam ser "mais de mil», "dez dúzias», etc. (cf. Diál. no 9, nota).

123 Siciónio, natural de Sícione, cidade da Acaia.

${ }^{124}$ Alguns editores cortam aqui a fala de Hermes, passando para Plutão, até ao fim do parágrafo e continuando pelo parágrafo seguinte.

${ }^{125}$ Iolau, companheiro de Héracles, muito popular na Beócia. 
HERMES - Não te dê cuidados, Plutão, que tos vou trazer imediatamente, todos se enfiada... creio que são sete.

PLUTÁO - Arrasta-os cá para baixo, enquanto ele, novamente regressado, de velho que era, à primeira juventude, acompanhará o funeral de cada um deles. 


\section{Térpsion ${ }^{126}$ E Plutão}

1] TÉRPSION — Ó Plutão, será justo eu ter morrido aos trinta anos, enquanto o velho Túcrito, que já passa dos noventa, ainda esteja vivo?

PLUTÃO - É justíssimo, Térpsion, que ele continue vivo, pois não deseja a morte de nenhum dos seus amigos, enquanto tu conspiravas constantemente contra ele, na mira de ficares com a herança.

TÉRPSION - Mas não devia ele, um velho já incapaz de gozar da sua fortuna, abandonar a vida, dando lugar aos novos?

PLUTÁO - Que nova lei tu estabeleces, Térpsion, estipulando que todo aquele que fique incapaz de gozar da sua fortuna deve morrer! Todavia, a Moira ${ }^{127}$ e a natureza dispuseram que fosse doutra maneira.

2] TÉRPSION - Nesse caso, é a elas que eu acuso por essa disposição. As coisas deviam passar-se mais ou menos assim: primeiro ia o mais velho, e a seguir a ele iria quem se lhe seguisse na idade, sem a mínima alteraçâo da ordem, sem ficar vivo o velhadas, só com os três dentes que lhe restam, quase cego, apoiado em quatro criados, com o nariz escorrendo de ranho, com os olhos cheios de remelas, incapaz de gozar a vida, enfim, um autêntico sepulcro com vida, escarnecido dos jovens, em vez de morrerem os jovenzinhos formosos e cheios de saúde. É tal e qual como se os rios corressem para cima. Finalmente, devia saber-se quando é que cada velho iria morrer, a fim de não tratarem escusadamente de alguns deles. Neste caso, porém, aplica-se o provérbio: « $A$ carroça à frente dos bois.»

3] Plutão - Mas isso, ó Térpsion, acaba por ser mais razoável do que tu julgas: porque é que vós cobiçais a fortuna de outrem e vos introduzis em casa dos velhos sem filhos, tentando

126 Térpsion, personagem provavelmente real, mas, como noutros diálogos, sobretudo representativa de um tipo social, aqui o tipo do adulador e parasita.

${ }^{127}$ As Moiras (ou Parcas), filhas de Zeus e de Témis (a Justiça), eram as divindades que presidiam ao destino dos humanos. Eram três: Cloto, Láquesis e Átropo. Láquesis determinava a parte de vida que cabia a cada pessoa e carregava a roca, que depunha nas máos de Cloto; Átropo, ao cortar o fio, punha termo aos dias de vida concedidos. Aqui, o singular, a Moira, deve referir-se, naturalmente, a Átropo, que cortava o fio. 
levá-los à certa? Por isso mesmo é que sois motivo de riso, quando enterrados antes dos velhos, facto que provoca enorme gozo em muita gente. Sim, que quanto mais vós fazeis votos por que os velhos morram, tanto maior gozo causa a toda a gente que vós morrais antes deles. Realmente, vós imaginastes uma nova arte, a de amar velhas e velhos, especialmente se náo têm filhos, pois os que têm filhos não suscitam o vosso amor. Mesmo assim, muitos daqueles que vós amais, compreendendo a perversidade do vosso amor, se por acaso têm filhos, fingem odiá-los, a fim de terem amadores; mas depois, nos seus testamentos, deixam de fora os antigos satélites, e o filho e a natureza, como é de justiça, se apoderam de toda a fortuna, enquanto os outros rangem os dentes, consumidos de raiva.

4] TÉRPSION - É bem verdade o que dizes. Quanto não comeu Túcrito do que era meu, dando a impressão de estar sempre prestes a morrer: sempre que eu entrava em sua casa, gemia e soltava uns pios profundos, como de um pintainho acabado de sair do ovo, de forma que eu, convencido de que ele em breve iria entrar no caixão, mandava-lhe grande quantidade de presentes, para que os meus rivais náo me ultrapassassem em generosidade; muitas vezes, passava as noites em claro, cheio de preocupaçôes e fazendo contas e planeando coisas, e terão sido talvez estas coisas, as insónias e as preocupaçóes, a causa da minha morte. Ao contrário, anteontem, depois de engolir o isco que eu lhe lançara, o velho, enquanto me enterravam, estava junto do meu túmulo a rir-se de mim.

5] PLUTÃo — Pois muito bem, ó Túcrito! Que vivas o máximo de tempo possível, que rias de tais fulanos e que não morras antes de teres mandado à tua frente todos os aduladores.

TÉRPSION - Uma coisa, ó Plutão, que me seria particularmente agradável, é que Caréades morresse antes de Túcrito.

PLUTÃo - Anima-te, Térpsion, pois também Fídon e Melanto e, enfim, todos os outros partirão antes do velho, minados pelas mesmas preocupaçóes.

TÉRPSION - Aprovado. Então que tu, Túcrito, vivas por muito tempo. 


\section{ZeNOFANTO ${ }^{128}$ E CALIDÉMIDES}

1] ZenOfanto - Então e tu, Calidémides, como é que morreste? No meu caso, era parasita de Dínias; então, tendo comido mais que a conta, tive uma congestáo, como sabes, pois assististe à minha morte.

CALIDÉMIDES - Sim, Zenofanto, assisti. O meu caso, porém, foi algo de insólito. Conheces, não é assim, o velho Pteodoro?

ZENOFANTO - Sim, um que não tem filhos, muito rico e cuja casa eu sabia que tu frequentavas assiduamente.

CALIDÉMIDES - Esse mesmo, do qual eu tratava e que me prometia que eu seria contemplado após a sua morte. Todavia, como a coisa se arrastava demasiado e o velho vivia mais tempo que Titono ${ }^{129}$, achei um caminho mais curto para chegar à herança: comprei um veneno e convenci o seu escançáo a que, logo que Pteodoro lhe pedisse de beber (e ele bebe o vinho razoavelmente puro), tivesse o veneno pronto, o deitasse na taça e lha oferecesse. E jurei que, caso ele assim fizesse, lhe concederia a liberdade.

ZENOFANTO - E que é que aconteceu? Tenho a impressão de que mais contar algo de extraordinário.

2] CALIDÉmides - Quando, após o banho, regressámos à sala, o moço, que tinha já duas taças preparadas (uma para Pteodoro - a que continha o veneno — , e a outra para mim), não sei como, enganou-se e deu-me a do veneno a mim e a que não tinha veneno a Pteodoro. Então o velho bebeu calmamente ${ }^{130}$, enquanto eu caí logo ali todo ao comprido, morto no lugar do velho... Mas... porque estás a rir, ó Zenofanto? Na verdade, não devias fazer troçar de um amigo.

ZENOFANTO - É que o que te aconteceu, Calidémides, tem muita graça... E como é que o velho reagiu a isso?

CALIDÉMIDES - Primeiro, ficou algo perturbado perante o inesperado da coisa, mas depois, tendo - creio eu — percebido

128 Zenofanto, Calidémides e outros são personagens provavelmente reais, mas representam sobretudo um tipo social: o dos parasitas caçadores de heranças.

129 Titono, filho de Laomedonte e irmáo de Príamo, foi amado por Eos (Aurora), a qual pediu a Zeus que concedesse a imortalidade a Titono, no que foi atendida... mas esqueceu-se de pedir também a eterna juventude, pelo que Titono, embora imortal, envelhecia eternamente.

${ }^{130} \mathrm{O}$ imperfeito «bebia», «ia bebendo» (aspecto contínuo) sugere o advérbio "calmamente», o qual já permite o uso do perfeito em português. 
o que se passara, desatou a rir com o que o escanção acabara de fazer.

ZENOFANTO - Mas tu não precisavas de te virar para a via mais rápida, pois a fortuna chegaria às tuas mãos pela via geral, mais segura, ainda que um pouco mais lenta. 


\section{CNÉMON ${ }^{131}$ E DAMnipo}

1] CNÉMON - É caso para citar o provérbio: «O veado caçou o leão".

DAMNIPO - Porque é que estás tão irritado, Cnémon?

CNÉMON - Queres saber porque é que estou tão irritado? Desgraçado de mim, que, sem querer e por me deixar enganar, acabo de deixar um herdeiro, privando da minha herança quem eu mais queria que ficasse com ela.

DAMNIPO - Como é que isso foi?

CNÉMON - Eu tratava de Hermolau, aquele fulano muito velho e sem filhos, na esperança de que ele morresse. Ele, por seu lado, não era sem prazer que recebia os meus serviços. Além disso, tive por bem e por acertado divulgar publicamente o meu testamento, no qual lhe havia deixado todos os meus bens, a fim de que ele me imitasse e procedesse da mesma maneira.

DAMNIPO - E ele que é que fez?

CNÉMON - O que ele tinha escrito no seu testamento, não sei, pois morri de repente, por me ter caído em cima o tecto da minha casa. E agora Hermolau possui os meus bens, como uma perca que tivesse engolido o anzol juntamente com o isco.

DAMNIPO - E não só... mas também a ti, o pescador, que armaste um engano a ti próprio.

CNÉMON - Parece que sim, e por isso me lamento.

${ }^{131}$ Cnémon e Damnipo são, mais uma vez, sobretudo personagens simbólicas. 
(Página deixada propositadamente em branco) 


\section{Símilo e Polístrato}

1] Símilo - Até que enfim, Polístrato, que também tu chegas cá às nossas bandas, depois de viveres, creio eu, não muito menos de cem anos.

POLÍSTRATO - Noventa e oito, Símilo.

Símilo - E então como é que passaste estes trinta anos depois da minha morte? Sim, pois, quando eu morri, tu tinhas à volta de setenta anos.

POLÍSTRATO - Muito agradavelmente, por estranho que isso te pareça.

SímILO - Estranho, sim, se tu, velho, doente e sem filhos, ainda foste capaz de gozar das coisas da vida.

2] Polístrato - Antes de mais, podia fazer tudo o que quisesse; além disso, tinha à minha volta muitos jovens formosos e mulheres mui graciosas e perfumes e vinho cheirando a flores, enfim, uma mesa mais farta que as da Sicília.

SíMILO - Isso é novidade para mim, pois sempre te conheci muito poupadinho.

POLÍSTRATO - É que, meu caro, todas as coisas boas chegavam até mim, trazidas por outros: por um lado, logo de manhã, acorriam à minha porta grandes multidóes, e depois era-me trazida de toda a terra toda a espécie de magníficos presentes.

SíMILO - Ó Polístrato, será que, depois da minha morte, te tornaste um soberano absoluto?

POLÍSTRATO - Não, mas tinha mais de dez mil ${ }^{132}$ apaixo$\operatorname{nados}^{133}$.

SímILO - Fazes-me rir! Tu, dessa idade, só com quatro dentes, e tendo apaixonados?!

POLÍSTRATO - Sim, por Zeus!, e os mais distintos da cidade. E mesmo sendo eu, como tu vês, velho e careca, cheio de remelas e ainda por cima ranhoso, eles tinham enorme prazer em me servir, e sentia-se feliz qualquer um de entre eles, a quem um lançasse nem que fosse um só olhar.

${ }^{132} \mathrm{O}$ texto diz «dez mil», que é um número indeterminado, que poderíamos traduzir, p. ex., por «mil», "um milhão»... (v. diál. no 5, nota).

${ }^{133}$ A tradução por "amantes» (nesta fala e na seguinte) poderia induzir em erro, pois trata-se de "amantes homens», como se vê logo a seguir... 
SímILO - Porventura também tu, à semelhança de Fáon, passaste Afrodite de barco, de Quios, e depois a deusa, a teu pedido, te concedeu seres outra vez jovem e belo como outrora e digno de ser amado?

POlístRATO - Não, mas, mesmo sendo como agora, eu era muito desejado.

SÍMILO - É um enigma isso que me contas.

3] Polístrato - Mesmo assim, é manifesto este grande amor que as pessoas têm aos velhos sem filhos e ricos.

SÍMILO - Agora, meu bravo, entendo a tua beleza: ela era a de Afrodite de ouro ${ }^{134}$ !

POlíSTRATO - Apesar de tudo, Símilo, não foi pouco o que eu gozei com os meus amantes, a bem dizer adorado por eles; mas muitas vezes tratava-os com dureza e até punha alguns na rua, mas eles rivalizavam e disputavam uns com os outros, a ver qual deles tinha maior consideração por mim.

SímILO - E entáo, por fim, como é que decidiste a respeito dos teus bens?

POLÍSTRATO - Em público, apregoava que tinha feito deste ou daquele meu herdeiro, e então esse acreditava e fazia-se ainda mais bajulador, mas deixei um outro testamento, esse verdadeiro, em que os mandei para o raio que os parta.

4] Símilo - E a quem é que o teu último testamento fez teu herdeiro? Porventura alguém da tua família?

POLÍSTRATO - Não, por Zeus!, mas antes um adolescente mui viçoso, um frígio, que eu comprara recentemente.

SímILO - Que idade mais ou menos tem ele, Polístrato?

POLÍSTRATO - Cerca de vinte anos.

SÍMILO - Agora já percebo em que é que ele te agradava.

POLÍSTRATO - Em todo o caso, era mais digno que os outros de ser meu herdeiro, muito embora seja bárbaro e debochado, a quem os próprios notáveis já estão fazendo a corte. Foi ele, pois, que herdou os meus bens, e agora conta-se entre as pessoas de boas famílias, embora tenha o queixo rapado e

134 "Afrodite de ouro" era uma designação corrente e poética da deusa, mas aqui joga-se com outro sentido: a beleza conferida (!) pelo dinheiro..., a beleza de quem é rico... 
uma língua bárbara, e é considerado mais nobre que Codro ${ }^{135}$, mais belo que Nireu ${ }^{136}$ e mais arguto que Ulisses.

Símilo - Pouco me importa! Até pode ser o general da Grécia, se assim entenderem: basta que os outros não sejam herdeiros.

${ }^{135}$ Codro foi o último dos lendários reis de Atenas.

${ }^{136}$ Nireu faz parte da galeria de beldades lendárias (cf. Diál. no 18). 
(Página deixada propositadamente em branco) 


\section{Caronte e Hermes}

1] CARONTE - Ouvi qual é a nossa ${ }^{137}$ situação: a barca, como vedes, é pequena para todos vós, e ainda por cima está podre e mete água por todos os lados; se baloiçar de um lado para o outro, vira-se e afunda-se. Vós também chegastes tantos ao mesmo tempo, cada um carregado de tanta bagagem... Ora, se embarcais com essa tralha toda, receio que venhais mais tarde a arrepender-vos, especialmente aqueles que não sabem nadar.

HERMES - Como havemos então de proceder, para termos uma boa navegação?

CARONTE - Eu explico-vos: é preciso que embarqueis nus, deixando na margem todas essas coisas supérfluas, pois, desse modo, dificilmente o barco poderia receber-vos. E tu, Hermes, tem cuidado, daqui em diante, não deixes entrar ninguém que não esteja nu e não se tenha separado da bagagem, conforme eu disse. Coloca-te junto da escada, examina-os bem, recebe-os e obriga-os a embarcar todos nus.

2] Hermes - Dizes bem, e é assim que faremos... Este aqui, o primeiro, quem é ele?

MENIPO - Sou eu, Menipo. Repara, Hermes, que o meu saco e o cajado já foram lançados ao pântano, e quanto ao meu manto, nem sequer o trouxe... e fiz muito bem.

HERMES - Embarca, Menipo, o melhor dos homens, e vai ocupar a presidência, ao lado do piloto, lá no alto, para observares todas as pessoas... E aqui este formoso, quem é ele?

3] Carmóleo - Sou Carmóleo de Mégara, cujo beijo custava dois talentos ${ }^{138}$.

HERMES - Nesse caso, despe-te da tua beleza, dos teus lábios mais dos seus beijos, da tua espessa cabeleira, do rosado das faces e, enfim, de toda a pele... Está muito bem, estás muito

137 Outras ediçốes preferem "vossa»; a variante vem desde muito cedo, desde que passou a confundir-se $\hat{v} \mu \hat{\imath} \nu$ com $\dot{\eta} \mu \hat{\imath} \nu$ ambos pronunciados [himín],

${ }^{138} \mathrm{O}$ talento não era uma moeda, mas aquilo a que chamamos uma "unidade de conto" (cf. dez contos de reis): 1 talento = 60 minas; 1 mina $=100 \mathrm{dracmas} ; 1 \mathrm{dracma}=6$ óbolos. Como se vê, trata-se de uma quantia elevadíssima. 
elegante. Sobe já! ... E esse aí, vestido de púrpura e com um diadema, todo altivo... Quem és tu?

4] LAMPICO - Lampico, tirano ${ }^{139}$ de Gela ${ }^{140}$.

HERMES - Ó Lampico, então porque é que te apresentas aqui com tanta coisa?

LAMPICO - O quê? devia vir todo nu, ó Hermes, eu, um tirano?

Hermes - Qual tirano, qual quê! Diz antes um simples morto. Portanto, deita tudo isso fora.

LAMPICO - Pronto, lá se foi a riqueza.

HERMES - Deita fora também a vaidade, ó Lampico, e a altivez, pois estas, ao caírem no barco, torná-lo-ão mais pesado.

LAMPICO - Mas... deixa-me ao menos ficar com o diadema e com o manto.

HERMES - De modo nenhum! Larga também isso.

LAMPICO - Pronto! Que mais ainda? Já larguei tudo, como vês.

HERMES — Também a crueldade, a insensatez, a insolência e a cólera, larga tudo isso.

LAMPICO - Pronto, estou completamente nu.

5] HERMES — Sobe depressa!... E tu aí, o gordo, bem aviado de carnes, quem és tu?

DAMÁSIAS - Sou Damásias, o atleta.

HERMES - Sim, tens ar disso; aliás, sei-o bem, por te ter visto muitas vezes nos ginásios.

DAMÁSIAS - Sim, Hermes... mas recebe-me, pois estou nu.

HERMES - Não estás nu, não, meu caro, assim envolvido em tanta carne. Portanto, despe-te delas, pois afundarias o barco, mal pusesses um pé dentro. Além disso, deita fora também essas coroas e as proclamaçóes de vitória.

${ }^{139}$ A tirania foi o regime político que, muitas vezes, sucedeu à monarquia e antecedeu a democracia; enquanto a monarquia era de origem divina, a tirania, em princípio, apoiava-se no Povo. Para os Antigos, o bom tirano era mais frequente que o déspota. Como aconteceu com outras palavras (sofista, demagogo...), tirano e tirania ganharam um sentido altamente pejorativo. Segundo Aristóteles (v. P. Lavedan, Dict. de la myth. et des antiquités grecques et romaines), "o tirano tem por única missão proteger o povo contra os ricos; começou sempre por ser um demagogo [outra palavra sem sentido necessariamente pejorativo: "condutor do Povo"], e é da essência da tirania combater a aristocracia».

${ }^{140}$ Gela, colónia grega na costa sul da Sicília. 
DAMÁSIAS - Pronto, agora, como vês, estou verdadeiramente nu e nas mesmas condiçóes que os outros mortos.

6] HeRMeS - Assim é melhor, estares sem peso. Portanto, entra... E tu aí, Cráton, póe de parte a tua riqueza, e mais a moleza e a volúpia; não tragas nem as vestes fúnebres nem os pergaminhos dos teus antepassados; Deixa também a linhagem, a glória e alguma aclamação que a cidade te tenha feito, bem como as inscriçôes nas tuas estátuas. Nem sequer digas que erigiram um grande túmulo em tua honra, pois isso também faz aumentar o peso, mesmo que só mencionado.

CRÁTON - Náo é por vontade minha, mas deitarei fora tudo isso. Sim, que poderia fazer?

7] HERMES - Ó lá... Tu aí, assim armado, que é que queres? Porque trazes esse troféu?

SOLDADO - Porque fui vencedor e me distingui, pelo que a cidade me honrou.

HERMES - Deixa o troféu aí no chão, pois aqui no Hades reina a paz e não temos nenhuma precisão de armas...[8] E este aqui, mui venerável e altivo, pelo menos a julgar pelo aspecto exterior, de sobrancelhas eriçadas, perdido em meditaçóes, quem é ele, assim com essas espessas barbas compridas?

MENIPO - Ó Hermes, é um filósofo, ou melhor, um charlatão, um tipo com grande lábia; portanto, manda-o despir-se também, e verás muita coisa risível escondida debaixo do manto.

HERMES - Antes de mais, desfaz-te desse aspecto exterior, e depois tudo o resto... Ó Zeus! Quanta charlatanice ele traz consigo, quanta ignorância, quanta polémica, quanta vanglória, quantas questôes insolúveis, palavras bicudas e conceitos retorcidos, mas também muitíssimo esforço inútil, não pouca tagarelice, cacarejos, linguagem subtil e, por Zeus!, todo este ouro, tanta volúpia, despudor, cólera, delícias e moleza. Nenhum desses defeitos me escapou, por muito que os dissimulasses. Larga também a mentira, a arrogância e a convicção de que és superior às outras pessoas. Se embarcares com toda essa bagagem, que navio, mesmo de cinquenta remadores, poderia contigo?

FILÓSOFO - Pois seja: largo tudo isso, já que assim o ordenas. 
9] MENIPO — Que ele largue também essa barba, ó Hermes, pois é pesada e farfalhuda, como vês: são pelo menos cinco minas $^{141}$ de cabelo.

HERMES - Dizes bem. Larga também essa coisa.

FILÓSOFO - E quem é que ma vai rapar?

HERMES - Aqui o Menipo pega no machado da construção naval e corta-a, servindo-se da escada como cepo.

MENIPO - Não, Hermes, dá-me antes uma serra, que assim tem mais piada.

HERMES - O machado serve muito bem... Pronto, agora tens mais aspecto humano, depois de te libertares desse cheiro a bode. MENIPO - Queres que eu lhe corte um pouco as sobrancelhas? HERMES - Sim, é claro, pois ele fê-las subir pela testa acima, dando de si um aspecto mais sobranceiro, não sei lá porquê. Mas... que vem a ser isto? Agora choras, meu monte de merda, e acobardas-te perante a morte? Vamos, entra!

MENIPO - Há ainda uma coisa, mais pesada, que ele tem debaixo do sovaco.

HERMES - O que é, ó Menipo?

MENIPO - A adulação, ó Hermes, que lhe foi muito útil em vida.

FILÓSOFO - Então também tu, ó Menipo, larga essa tua liberdade, a tua franqueza no falar, o teu desprezo pela dor, a tua magnanimidade, e o teu riso... Sim, pois, entre nós todos, és o único que ris.

HERMES - De maneira nenhuma, mas conserva essas qualidades, pois elas são muito leves, fáceis de transportar e úteis à viagem...[10] E tu aí, o orador, larga essa chorrilho interminável de sentenças, as antíteses, os paralelismos, os períodos, os barbarismos e a restante bagagem dos teus discursos.

FILÓSOFO - Pronto, já larguei.

HERMES - Muito bem. Portanto, tu aí, solta as amarras, enquanto nós recolhemos a escada. Levantar a âncora! Desferrar a vela! Barqueiro, dirige o leme! Boa viagem! ${ }^{142} \ldots$ [11] Vós aí, gente frívola, porque, vos lamuriais especialmente tu, o filósofo, a quem há pouco raparam a barba?

${ }^{141}$ A mina, além de ser uma moeda, equivalia como peso, a cerca de $436 \mathrm{~g}$, mas este valor variava conforme as épocas e os locais. Neste caso, não interessa o peso certo...

142 Seguimos a lição dos mss. recentiores, mas também poderíamos adoptar a lição equivalente a «Boa sorte!». 
FILÓSOFO - É que eu, ó Hermes, acreditava que a alma era imortal e persistia.

MENIPO - Ele está a mentir. Sim, é óbvio que o que o aflige é outra coisa.

HERMES - O quê?

MENIPO - O facto de nunca mais comer jantares caríssimos, nem sair à noite sem ninguém dar por isso, com a cabeça coberta pelo manto, a fim de percorrer as casas de prostituição; nem, logo de manhá, receber dinheiro, endrominando os jovens com a sua ciência. É isso que o aflige.

FILÓSOFO - Mas tu, ó Menipo, não te incomoda teres morrido?

MENIPO - Mas como, se eu próprio me apressei a ir ao encontro da morte, sem que ninguém me solicitasse?!... [12] Mas... não ouvem, no meio da nossa conversa, um rumor como que de pessoas gritando do lado de terra?

HERMES - Sim, Menipo, e não vem de um único sítio, mas umas pessoas, reunidas na Assembleia, todas contentes, riem todas elas com a morte de Lampico, enquanto a mulher deste é assaltada pelas outras mulheres, e até os filhos, ainda de tenra idade, apanham inúmeras pedradas dos outros miúdos... Outras pessoas, em Sícion, elogiam o orador Diofanto, que profere uma oração fúnebre em honra de Cráton, aqui presente. E, por Zeus!, também a mãe de Damásias, numa gritaria estridente, dá início ao canto fúnebre entoado pelas mulheres em honra de Damásias. Mas a ti, Menipo, ninguém te chora, és o único que jazes em completo silêncio.

13] MENIPO - De modo nenhum, mas, em breve, ouvirás os cáes uivando lugubremente por mim, e os corvos batendo as asas, quando se reunirem para me darem sepultura.

HERMES - És um tipo corajoso, ó Menipo... Bem, já que chegámos ao fim da viagem, vós dirigi-vos ao tribunal, seguindo a direito por aquele caminho além, enquanto eu mais o barqueiro vamos passar outros mortos.

MENIPO - Boa viagem, ó Hermes! Quanto a nós, avancemos... Mas... porque vos demorais? Tereis mesmo de ser julgados... e dizem que as sentenças são pesadas: $\operatorname{rodas}^{143}$, pedras e abutres. Além disso, será mostrada a cada um a vida que ele levou.

143 «rodas, pedras e abutres», referência a diversos tipos de tortura. 
(Página deixada propositadamente em branco) 


\section{Crates e Diógenes}

1] CRATES - Ó Diógenes, conhecias Mérico, um tipo rico, muito rico, de Corinto, que tinha muitos navios mercantes, e cujo primo, Arísteas, era igualmente rico? Ora, este costumava citar aquele passo de Homero: "Ou tu me levantas, ou eu a ti».

DIÓGENES - A que propósito vem isso, ó Crates?

CRATES - É que eles cortejavam-se mutuamente, cada um na mira da herança do outro; embora fossem da mesma idade, deram publicidade aos respectivos testamentos: caso Mérico morresse antes de Arísteas, deixá-lo-ia dono e senhor de todos os seus bens; do mesmo modo, Arísteas em relação a Mérico, se morresse antes deste. Ficara tudo escrito. Então, cortejavam-se mutuamente, rivalizando em adulaçáo. Os adivinhos (uns que vaticinavam o futuro por meio dos astros, outros através dos sonhos, à maneira dos Caldeus, e até o próprio Pítio ${ }^{144}$ ), davam vantagem ora a Arísteas, ora a Mérico, e o prato da balança pendia ora para um, ora para outro.

2] DiÓGENES - E como acabou isso, ó Crates? É coisa digna de se ouvir.

CRATES - Morreram ambos no mesmo dia, pelo que as heranças foram respectivamente para Eunómio e Trásicles, ambos seus parentes, que nunca poderiam adivinhar que as coisas iriam acontecer assim. De facto, navegavam eles de Sícion para Cirra, e eis que, a meio da viagem, deram com o iápige ${ }^{145}$, que os apanhou de lado e os fez virou.

3] DióGENES — Bem feito! Cá nós, quando éramos vivos, não pensávamos nenhuma dessas coisas a respeito uns dos outros; eu nunca desejei que Antístenes ${ }^{146}$ morresse, para herdar o seu cajado (um cajado feito por ele, muitíssimo rijo, de zambujeiro); nem tu, ó Crates - creio eu — ambicionavas herdar por minha morte os meus bens: o tonel e o bornal com duas quénices ${ }^{147}$ de tremoços.

CRATES - Eu não tinha precisão de nada disso, nem tu, Diógenes. O que era mesmo preciso, tu herdaste-o de Antístenes,

\footnotetext{
${ }^{144}$ Apolo.

145 Vento do quadrante de noroeste...

${ }^{146}$ Este passo mostra a sequência da direcção da escola cínica: Antístenes, seu fundador, Diógenes e Crates.

${ }^{147}$ A quénice equivalia mais ou menos a um litro.
} 
e eu herdei-o de ti, e era muito melhor e mais estimável que o trono da Pérsia.

DIÓGENES - Que é isso de que estás a falar?

CRATES - A sabedoria, a moderação, a verdade, a franqueza e a liberdade.

DIÓGENES — Sim, por Zeus!, recordo-me de ter recebido essa fortuna de Antístenes e de ta ter deixado ainda maior.

4] CRATES - Mas as outras pessoas não davam importância a tais bens, e ninguém nos apaparicava na expectativa de vir a ser nosso herdeiro, pois toda a gente olhava apenas ao dinheiro.

DIÓGENES - Naturalmente. De facto, essas pessoas não tinham sítio onde receber de nós tais bens, pois estavam «esburacados» ${ }^{148}$ pela volúpia, como bolsas velhas, de modo que, se alguém lhes atirava para dentro sabedoria, franqueza ou verdade, logo estes bens escorriam para fora e se escapavam, pelo facto de o fundo não poder contê-los, tal como acontece com as filhas de Dánao ${ }^{149}$ a tentarem esvaziar o tonel crivado de buracos. Mas o ouro, esse defendiam-no com unhas e dentes, fosse por que processo fosse.

CRATES - Portanto, nós, mesmo aqui, conservaremos a nossa riqueza, ao passo que eles virão com um óbolo, e mesmo esse só até chegarem junto do barqueiro.

${ }^{148}$ O termo grego significa «esgotado», mas também "gasto», «usado», que aqui pode entender-se no sentido de "esburacado». Aliás, a frase é usual nesta época.

${ }^{149}$ As filhas de Dánao são as Danaides, em número de cinquenta. Por matarem os respectivos maridos, foram condenadas a encher continuamente um tonel esburacado. 


\section{Alexandre e Aníbal}

1] AlEXANDre - Eu é que devo ter a primazia sobre ti, ó Líbio $^{150}$, pois sou melhor que tu.

ANÍBAL - Não, eu é que devo ter a primazia.

ALEXANDRE - Nesse caso, que seja $\operatorname{Minos}^{151}$ a julgar.

MINOS - Quem sois vós?

ALEXANDRE — Este aqui é Aníbal, o cartaginês, e eu sou Alexandre, filho de Filipe.

Minos - Por Zeus! Sois ambos famosos. Então qual é o motivo da vossa disputa?

ALEXANDRE - É sobre a ordem de precedência: este aqui afirma ter sido melhor general que eu, enquanto eu sustento, como todos sabem, que, em matéria de guerra, sou superior não só a ele, mas também a quase todos os que me precederam.

Minos - Então fale cada um por sua vez. Tu, ó Líbio, fala primeiro.

2] ANÍBAL - Para já, ó Minos, ganhei pelo facto de também eu ter aprendido na terra a língua grega, pelo que nem nesta matéria ele me levará a palma. Além disso, afirmo que são particularmente dignos de louvor aqueles que, nada sendo nos seus princípios, chegaram, porém, a uma elevada situação, conseguindo, por esforço próprio, um grande poderio e sendo dignos de ocupar o comando supremo. Ora eu, tendo invadido a Ibéria com um punhado de homens, primeiro como lugar-tenente de meu irmáo, fui cumulado das maiores honrarias e considerado o mais valoroso. Venci os Celtiberos, dominei os Gálatas do Ocidente e, tendo atravessado as altas montanhas, devastei todas as terras à volta do rio Erídano, destruí enorme quantidade de cidades, conquistei a planície itálica, cheguei aos arredores da cidade capital e matei tantas pessoas num único dia, que medi os seus anéis em medimnos e, com os cadáveres, fiz pontes sobre os rios. E tudo isso eu fiz, sem me intitular filho de Ámon, sem me fazer passar por um deus ou sem descrever os sonhos de minha mãe, mas,

${ }^{150}$ Líbio = Africano. A Líbia compreendia todo o norte de África; aqui, a palavra significa, propriamente, "Cartaginês».

${ }^{151}$ Minos, Éaco e Radamanto eram os três juízes do reino dos mortos, o (reino de) Hades (ou Plutáo). Este, embora podendo julgar directamente os mortos, em geral delegava essas funçóes num dos três juízes. 
pelo contrário, confessando-me simples ser humano, bati-me contra os generais mais competentes e ataquei os soldados mais belicosos, e não defrontei Medos e Arménios, que batem em retirada mesmo antes de serem perseguidos e que dão sem demora a vitória a quem ousa atacá-los... [3] Alexandre, porém, tendo recebido o reino de seu pai, aumentou-o e acrescentou-o muitíssimo, aproveitando o impulso da fortuna. Todavia, logo que venceu e dominou esse miserável do Dario em Isso e em Arbela, abandonou os costumes pátrios e considerou-se digno de ser adorado, adoptou o modo de vida dos Medos e chegava a matar vergonhosamente os seus amigos durante os banquetes ou mandava-os prender para os matar. Eu, porém, governei a minha pátria com equidade, e, quando ela me mandou chamar, numa altura em que uma numerosa armada inimiga navegava em direcção à Líbia, imediatamente obedeci e me apresentei como simples cidadão comum, e, quando fui condenado, suportei a coisa com resignação. E procedi desse modo, mesmo sendo bárbaro e ignorante da cultura grega, sem recitar Homero, como este aqui, e sem ter sido educado pelo sofista ${ }^{152}$ Aristóteles, mas unicamente inspirado pela minha boa natureza. E são estas as qualidades em que eu afirmo ser superior a Alexandre. Se ele é mais belo que eu pelo facto de cingir a cabeça com um diadema, talvez isso seja, para os Macedónios, um título de nobreza, mas não é por isso que ele seria considerado superior a um homem valoroso e com dons de comando, que usou mais da sua inteligência que da sorte.

MiNOS - Ele acaba de proferir em sua defesa um discurso a que não falta nobreza, e que até nem seria de esperar da parte de um líbio. E tu, Alexandre, que respondes a essas palavras?

4] ALEXANDRE - Ó Minos, eu não precisava de responder a um homem tão atrevido. De facto, a minha simples fama bastaria para te esclarecer quão grande rei eu fui e quão grande salteador ele foi. Mesmo assim, considera lá se eu lhe fui só um pouco superior, eu que, tendo chegado ainda muito novo à governação e tendo tomado posse de um reino conturbado, persegui os assassinos de meu pai e, depois de ter aterrorizado a Grécia com o massacre dos Tebanos, fui por eles aclamado general; e não julguei digno de mim ocupar-me apenas do reino da Macedónia e contentar-me com mandar nas terras que meu

${ }^{152} \mathrm{O}$ texto diz mesmo "sofista", com todo o seu sentido depreciativo. 
pai me deixou, mas antes, tendo lançado o pensamento sobre toda a terra e tendo considerado que seria muito mau não conquistar todo o mundo, invadi a Ásia à frente de um pequeno contingente e saí vencedor numa grande batalha nas margens do Granico; depois, tendo conquistado a Lídia, a Jónia, a Frígia e, enfim, tudo o que surgia no meu caminho, dirigi-me a Isso, onde Dario me aguardava à frente de um exército de muitas dezenas de milhares de homens... [5] O que se seguiu a isto, ó Minos, já vós aqui sabeis: quantos mortos num só dia eu vos enviei cá para baixo. Diz o barqueiro que, nesse dia, o barco não foi suficiente para todos eles, pelo que muitos deles construíram jangadas e atravessaram nelas. Participei pessoalmente nesta batalha, correndo perigos e arriscando-me a ser ferido. Finalmente, para não te descrever o que aconteceu em Tiro ou em Arbela, basta dizer que cheguei à terra dos Indos e fiz do seu Oceano a fronteira do Império, tomei-lhes os elefantes, apoderei-me de Poro e, tendo atravessado o Tánais, venci, numa grande batalha de cavalaria, os Citas, que são homens de não pouco valor. Além disso, concedi benefícios ao meus amigos e castiguei os meus inimigos. E se surgi aos olhos dos homens como sendo um deus, eles são dignos de perdão, ao acreditarem numa coisa dessas a meu respeito, dada a grandeza das minhas façanhas...

[6] Finalmente, eu morri em pleno reinado, enquanto este morreu no exílio na corte de Prúsias, na Bitínia, como convinha a um homem do mais celerado e mais cruel que existe. De facto, passo em claro a maneira como venceu os Ítalos, não pela força, mas pela maldade, pela perfídia e pelos embustes, e nada segundo as leis da lealdade e da transparência. E uma vez que ele me censurou pela minha vida dissoluta, acho melhor omitir o que ele, esse homem admirável, fazia em Cápua, frequentando prostitutas e gastando em prazeres o tempo que devia dedicar à guerra. Se eu, por considerar as regióes ocidentais de pouca importância, não me tivesse lançado de preferência contra o Oriente, que grande feito não teria realizado, ao conquistar a Itália sem derramamento de sangue e submetendo a Líbia e as terras até Gadiros [Cádis]! Pelo contrário, não considerei essas terras um bom objecto de guerra, pois já estavam submetidas e já reconheciam em mim o seu Senhor. E tenho dito. E tu, Minos, procede ao julgamento, pois, de entre muitos outros factos, bastará o que ficou dito. 
7] CIPIĀO ${ }^{153}$ - Não faças isso, sem primeiro me teres escutado.

Minos - Mas quem és tu, meu caro? E donde és natural, não me dirás?

CIPIÃO - Sou o italiota Cipião, o general que conquistou Cartago e se apoderou da Líbia em grandes batalhas.

MiNOS - Então que é que tens a dizer?

CIPIÃO - Para já, digo que sou inferior a Alexandre, mas superior a Aníbal, eu que o venci, persegui e obriguei a fugir sem honra nem glória. Na verdade, este fulano é muito descarado, ao rivalizar com Alexandre, com o qual nem mesmo eu, Cipião, que venci Aníbal, me atrevo a comparar-me.

MiNOS - Por Zeus!, ó Cipião, é bem pensado o que dizes. Portanto, que Alexandre seja classificado em primeiro lugar, tu a seguir a ele, e depois, em terceiro lugar, se estais de acordo, Aníbal, que também não é de desprezar.

${ }^{153}$ Trata-se de Públio Cornélio Cipião Africano (235-183 a.C.), célebre general romano que, como ele próprio diz logo a seguir, conquistou Cartago e se apoderou da Líbia em grandes batalhas. De notar que se designa à sua pessoa como sendo «italiota» (e não «Romano» ou «Africano». 


\section{Diógenes E Alexandre}

1] DiÓGENES — Que é isto, Alexandre? Também tu morreste, como todos nós?

ALEXANDRE - É como vês, Diógenes. Aliás, não é de espantar que, sendo humano, tenha morrido.

DIÓGENES - Quer dizer que Ámon ${ }^{154}$ mentiu, ao dizer que tu eras seu filho, mas tu eras, afinal, filho de Filipe?

ALEXANDRE - De Filipe, é claro, pois não estaria agora morto, se fosse filho de Ámon.

DIÓGENES - Mas também a respeito de Olimpíade se diziam coisas do género, por exemplo, que uma serpente costumava ter relaçóes com ela e era vista no seu leito, que tu foste gerado desse modo, e Filipe fora enganado, cuidando que tu eras filho dele.

ALEXANDRE - Tal como tu, também eu ouvi dizer isso, mas agora verifico que náo havia nada de verdade naquilo que minha mãe e os sacerdotes de Ámon diziam.

DIÓGENES - Mas, pelo menos, a sua mentira, ó Alexandre, não deixou de ser proveitosa para ti e para a tua política, já que muitos homens tremiam de medo, ao acreditar que tu eras um deus...

2] Mas, diz-me cá: A quem deixaste esse teu grandioso império?

ALEXANDRE - Não sei, Diógenes, pois não tive tempo para pensar nesse assunto, a náo ser apenas que, prestes a morrer, entreguei o anel a Perdicas... Mas... porque te ris, ó Diógenes?

DIÓGENES - Ora... porque havia de ser, senão por me lembrar do que toda a Grécia procedia, mal tu acabaste de receber o trono, com todos a adularem-te e a elegerem-te seu protector e general contra os bárbaros; alguns chegaram mesmo a juntar-te aos doze deuses, a erigir templos em tua honra e a fazer-te sacrifícios na qualidade de filho da serpente... Mas... diz-me cá: onde é que os Macedónios te sepultaram?

3] ALEXANDRE - Há três dias que ainda jazo em Babilónia, mas o meu escudeiro Ptolomeu promete que, mal tenha tempo livre da desordem que tem pela frente, me levará para o Egipto e me dará aí sepultura, a fim de me tornar mais um de entre os deuses egípcios.

${ }^{154}$ Ámon, deus egípcio confundido com Zeus. A lenda da origem divina de Alexandre merece as corrosivas farpas de Luciano. 
DIÓGENES - Então, ó Alexandre, não será caso para rir, ao ver que, mesmo no Hades, ainda estás louco, esperando tornar-te Anúbis ou Osíris? Não tenhas essa esperança, ó diviníssima criatura, pois a ninguém, de entre os que uma vez atravessaram o pântano e passaram para o lado de dentro da entrada, é permitido subir lá acima. De facto, Éaco não é assim tão descuidado, nem Cérbero $^{155}$ tão menosprezável... [4] Mas teria todo o gosto em que me informasses de uma coisa, de como suportas, ao meditar nisso, a ideia da grande felicidade que abandonaste ao chegar aqui: guardas de corpo, escudeiros, sátrapas, tanto ouro, povos que te adoravam, Babilónia e Bactras, as enormes feras, a honra e a glória, os cortejos triunfais, em que tu seguias à frente, com uma fita branca na cabeça e um manto de púrpura. Quando te lembras disso, não ficas triste? ... Porque choras, meu imbecil? Então o sábio Aristóteles ${ }^{156}$ não te ensinou a não considerar seguros os bens que nos vêm da sorte?

5] ALEXANDRE - Sábio, esse, o mais manhoso de todos os aduladores?! Deixa que só eu conheça as manhas de Aristóteles, quantas coisas me pediu, quantas cartas me escreveu, como abusou de mim e do meu entusiasmo pela cultura, adulando-me e elogiando-me ora pela minha beleza, como sendo esta uma parte do bem, ora pelos meus actos e pela minha riqueza. De facto, ele considerava que esta também era um bem, a ponto de ele próprio não se envergonhar de a aceitar. Um vigarista, um charlatão, é o que ele é, ó Diógenes. Um benefício, porém, retirei da sua sabedoria: o facto de me afligir com essas coisas que tu há pouco enumeraste como sendo os maiores bens.

6] DiógEnES — Sabes o que tens a fazer? Vou indicar-te um remédio para a tua tristeza: uma vez que aqui não cresce o eléboro $^{157}$, ao menos farta-te à boca cheia e bebe e torna a beber muitas vezes a água do Lete ${ }^{158}$. Desse modo, deixarás de te afligir com os bens de que fala Aristóteles... Mas... eis que avisto além

155 Cérbero é o cão de guarda do reino de Hades; é geralmente representado com três cabeças.

${ }^{156}$ Aristóteles, mestre de letras e filosofia e director espiritual de Alexandre, é o principal responsável pelo filelenismo do príncipe e depois monarca macedónio; com a conquista da Grécia, a língua e a cultura grega espalharam-se por todo o Mediterrâneo.

157 O eléboro é uma planta a que se atribuía a propriedade de curar a loucura.

${ }^{158}$ A água do rio Lete (rio do "esquecimento»), quando ingerida, fazia os mortos esquecerem-se da vida terrena. 
esse tal $\mathrm{Clito}^{159}$, Calístenes e muitos outros, que avançam contra ti, com ar de quererem despedaçar-te e vingarem-se do mal que lhes fizeste. Por isso, segue por outro caminho e bebe muitas vezes, como eu te disse.

${ }^{159}$ Irmão de leite e general de Alexandre, ao qual se refere Filipe no Diálogo 14: «Clito, a quem tu, enquanto ele jantava, assassinaste, varando-o de lado a lado com uma seta, só pelo facto de ele ter ousado elogiar as minhas façanhas em comparação com as tuas». 
(Página deixada propositadamente em branco) 


\section{Filipe e Alexandre}

1] FILIPE - Ó Alexandre, agora não poderás negar que és meu filho, pois não terias morrido, caso fosses filho de Ámon.

ALEXANDRE - Eu também não desconhecia, meu pai, que sou filho de Filipe filho de Amintas, mas aceitei o oráculo, convencido de que era útil à minha vida.

FILIPE - É o quê? Então parece-te útil apresentares-te como uma pessoa pronta a ser enganada pelos profetas?

ALEXANDRE - Nada disso, mas os bárbaros ficavam estarrecidos diante de mim, e nenhum deles me resistia, convencidos de que lutavam contra um deus, pelo que eu os dominava mais facilmente.

2] FILIPE - Mas que soldados verdadeiramente belicosos é que tu dominaste, tu que sempre defrontaste homens cobardes, que se defendiam com arquinhos, com pequenas lanças e com escudos de vime? Grande gesta seria vencer os Gregos, os Beócios, os Fócios e os Atenienses, e subjugar os hoplitas da Arcádia, ou a cavalaria da Tessália, ou os lançadores de dardo da Eleia, ou a infantaria ligeira dos Mantinenses, ou os Trácios, os Ilírios ou os Peónios... Isso é que seria uma grande façanha. Mas Medos, Persas e Caldeus, homens cobertos de ouro e efeminados, náo sabes como é que, antes de ti, os dominaram os dez mil que marcharam com Clearco ${ }^{160}$, e como eles, sem esperarem por chegarem à luta corpo a corpo, se puseram em debandada, mesmo antes que uma flecha os atingisse?

3] AleXANDrE - Mas, meu pai, os Citas e os elefantes dos Indos não constituem façanha de somenos importância, e, no entanto, eu venci-os, sem provocar dissensóes entre eles e sem comprar com traições as minhas vitórias. Também nunca faltei ao meu juramento, nem me neguei a cumprir uma promessa, nem cometi qualquer deslealdade, a fim de vencer. E quanto aos Gregos, uns dominei-os sem verter sangue, e, quanto aos Tebanos, talvez tenhas ouvido como os tratei.

FILIPE - Sei tudo isso, pois me foi contado por Clito, a quem tu, enquanto ele jantava, assassinaste, varando-o de lado a lado com uma seta, só pelo facto de ele ter ousado elogiar

${ }^{160}$ Este episódio dos «dez mil» é o tema da Anábase de Xenofonte. 
as minhas façanhas em comparação com as tuas... [4] Além disso, tu renunciaste à clâmide macedónica e, segundo se diz, trocaste-a pelo manto persa [kándys], e cingiste a cabeça com a tiara direita e julgavas-te digno de ser adorado pelos Macedónios, que eram homens livres, e ainda - o mais ridículo de tudo - imitavas os costumes dos povos vencidos. Sim, passo em claro todos as outros actos, como encerrar homens educados na jaula dos leôes, os casamentos que tu fizeste e a tua paixão excessiva por Hefestiáo. Uma só coisa louvei em ti, ao ouvir dizer que te abstiveste de tocar na esposa de Dario, que era muito bela, e que cuidaste da mãe e das filhas dele. Isso foi acçáo digna de um rei.

5] AlEXANDRE - E a minha temeridade, meu pai, não a elogias, por exemplo no país dos Oxidracas ${ }^{161}$, onde fui o primeiro a saltar para dentro das muralhas e a receber tantos ferimentos?

FILIPE - Náo te elogio esse feito, Alexandre, não porque não considere belo o facto de um rei ser algumas vezes ferido e afrontar o perigo à frente do exército, mas porque, no teu caso, isso náo te convinha mesmo nada. De facto, se, ao quereres passar por um deus, alguma vez fosses ferido e te vissem a ser retirado de maca do campo de batalha, todo coberto de sangue, gemendo por via dos ferimentos, isso seria objecto de riso para quem estivesse a assistir, e provar-se-ia que Ámon era um charlatão e um falso adivinho, e que os seus profetas eram uns aduladores. E quem não desataria a rir, ao ver o filho de Zeus ${ }^{162}$ desmaiado e necessitado de cuidados médicos? Mas agora, que já estás morto, não crês que há muitas pessoas que troçam desse teu fingimento, ao verem o cadáver do deus estendido ao comprido, já a apodrecer e inchado, como costuma acontecer com todos os corpos? Aliás, ó Alexandre, mesmo essa coisa que dizias ser-te útil, isto é, o facto de, por essa circunstância, venceres mais facilmente, precisamente essa retirava boa parte da glória aos teus feitos, pois fazia parecer inferior tudo o que desse a impressão de ser realizado com a ajuda de um deus.

6] ALEXANDRE — Não é essa a opinião das pessoas a meu respeito, mas antes consideram-me um rival de Héracles e de

161 Povo da Índia.

162 O deus egípcio Ámon estava identificado com o Zeus grego. 
Dioniso. E na verdade, nenhum deles foi capaz de tomar o [rochedo de] Aorno ${ }^{163}$ : só eu me apoderei dele.

FILIPE - Ó Alexandre, não vês que estás a dizer tal coisa como se fosses filho de Ámon, ao comparares-te com Héracles e com Dioniso? Nem mesmo agora deixarás essa tua soberba, te conhecerás a ti mesmo e te compenetrarás de que já estás morto?

${ }^{163}$ Rochedo e fortaleza da Índia. A palavra significa «inacessível às aves». 
(Página deixada propositadamente em branco) 


\section{Aquiles E ANTíloco}

1] Antíloco - Ó Aquiles, que barbaridades tu dizias outro dia a Ulisses a respeito da morte! Como essas palavras eram ignóbeis e indignas de ambos os teus mestres, Quíron ${ }^{164}$ e Fénix! Sim, que eu bem te ouvi, quando dizias que antes querias servir como trabalhador rural às ordens de um desses homens sem terra própria e sem grandes meios de fortuna, do que ser rei de todos os mortos. Essas palavras talvez fossem próprias de um frígio reles, cobarde e apegado à vida mais do que é decente; mas que o filho de Peleu, aquele que, de entre todos os heróis, era o que mais gostava de se expor aos perigos, tenha a seu respeito pensamentos tão baixos, é uma grande vergonha, contrária aos feitos que tu realizaste em vida, tu que, podendo reinar na Ftiótida durante longo tempo, mas sem glória, escolheste de bom grado uma morte gloriosa.

2] AQUILES - Ó filho de Nestor, é que eu, nessa altura, como ainda não tinha experiência do mundo aqui de baixo, e desconhecia qual das duas situaçóes era a melhor, dava mais valor a essa miserável gloríola, do que à vida. Agora, porém, compreendo como essa glória é vã, por muito que os poetas lá de cima a celebrem. Aqui entre os mortos, ó Antíloco, reina a igualdade, e náo existe nem a beleza nem o poder, mas jazemos todos rodeados da mesma escuridão, sem nos distinguirmos uns dos outros; nem os mortos do lado troiano me temem, nem os do lado dos Aqueus me servem: a igualdade de direitos é perfeita, e um morto é igual a outro morto, "quer seja mau, quer seja bom». É isto que me aflige e me faz sofrer pelo facto de não ser um serviçal, mas vivo.

3] ANTÍloco — Mas, ó Aquiles, que se há-de fazer? De facto, assim o decretou a Natureza: que todos morressem, sem excepção, de modo que temos de nos submeter a essa lei natural e não nos afligirmos com o que está determinado. De resto, estás a ver quantos dos teus companheiros aqui estamos à tua volta. Dentro de pouco tempo, também Ulisses aqui chegará forçosamente. Ora, a partilha da desgraça e o facto de uma pessoa náo ser a única a sofrer conferem uma certa consolação.

${ }^{164}$ Quíron é um centauro, meio homem e meio cavalo (hipocentauro). Especialista, entre outras artes, em música e medicina. 
Póe os olhos em Héracles ${ }^{165}$, Meléagro e tantos outros varôes admiráveis, os quais — creio eu — não aceitariam voltar lá acima, caso alguém os mandasse servir homens sem herança e sem fortuna.

4] AQUILES - É um conselho de amigo, mas, de qualquer modo, aflige-me a lembrança da vida terrena... e julgo que o mesmo acontece com todos vós. Mas, se não concordais comigo, então estais ainda pior, pois suportais em silêncio esta situação.

ANTÍlOCO — Pior, não, ó Aquiles, mas melhor, porque nos apercebemos de como é inútil falar. De facto, pareceu-nos bem estarmos calados, aguentar e sofrer, para náo sermos motivo de troça, como tu, ao exprimires tais desejos.

${ }^{165}$ A natureza simultaneamente humana e divina de Héracles é motivo de um raciocínio muito mordaz no diálogo seguinte («Diógenes e Héracles). 


\section{Diógenes e Héracles}

1] DiÓGENES — Este sujeito aqui não é Héracles? Não é outro... por Héracles!: o arco, a maça, a pele de leão, a corpulência... é Héracles sem tirar nem pôr. Mas entáo... está morto, sendo filho de Zeus? Diz-me cá, ó glorioso vencedor: tu estás mesmo morto? É que, lá na terra, fazia-te sacrifícios como a um deus.

HÉRACles - E fazias muito bem, já que o verdadeiro Héracles está no céu, na companhia dos deuses, "e possui Hebe $e^{166}$ dos belos tornozelos». Eu aqui sou apenas a sua imagem.

DIÓGENES - É o quê? Uma imagem do deus? Será possível que alguém seja metade deus [imortal], e que a outra metade esteja morta?

HÉRACLES - Sim, pois aquele, o deus, não morreu, mas eu aqui sou o seu simulacro.

2] DIÓGENES - Estou a entender: ele, o outro, entregou-te a Plutáo, como substituto, em seu lugar... e tu, portanto, estás morto em vez dele, o outro...

HÉRACLES - É mais ou menos isso.

DIÓGENES - Mas entáo... como é que Éaco ${ }^{167}$, rigoroso como é, não descobriu que tu não eras ... o outro, e deixou entrar o falso Héracles que se lhe apresentava?

HÉRACLES - É que este parecia-se com o outro... rigorosamente ${ }^{168}$.

DIÓGENES - É verdade, é de facto rigorosamente parecido com ele... Mas vê lá não suceda o contrário: que tu sejas o Héracles verdadeiro, e que o seu simulacro é que tenha desposado Hebe e esteja na companhia dos deuses...

3] HÉRACLES - És muito atrevido e tagarela. Se não deixas de troçar de mim, náo tarda que fiques a saber de que deus eu sou simulacro.

DIÓGENES - De facto, o arco está de fora e pronto a funcionar... Mas porque é que eu ainda havia de ter medo de

${ }^{166}$ Hebe, deusa da juventude, começou por servir à mesa dos deuses olímpicos, mas posteriormente foi dada em casamento ao recém-chegado Héracles.

167 Éaco, um dos juízes do Inferno, juntamente com Minos e Radamanto.

${ }^{168}$ Rigorosamente joga com rigoroso mais acima. 
ti, uma vez que estou morto? Em todo o caso, diz-me cá, por Héracles! ${ }^{169}$, quer dizer... por ti!: Quando aquele era vivo, vivias dentro dele, na qualidade de simulacro... ou vós éreis um só enquanto vivos, mas, quando vós morrestes, vos separastes, tendo um voado para junto dos deuses, enquanto tu, seu simulacro, te apresentaste no Hades, como seria de esperar?

HÉRACLES - Eu nem devia responder a um homem deliberadamente trocista. Em todo o caso, ouve lá esta: a parte de Anfitriáo ${ }^{170}$ que existia em Héracles, essa morreu, e eu sou toda essa parte; mas a parte de Zeus, essa está no céu, em convivência com os deuses.

4] Diógenes - Agora percebo perfeitamente: dizes tu que Alcmena deu à luz dois Héracles de uma só vez — um como obra de Anfitriáo, e outro gerado por Zeus, de modo que passou despercebido o facto de vós serdes gémeos, filhos da mesma mãe.

HÉRACLES - Nada disso, meu cretino! Na realidade, éramos ambos a mesma pessoa.

DIÓGENES - Não é fácil de compreender essa coisa de existirem dois Héracles unidos num só... a não ser que vós fôsseis uma espécie de hipocentauro ${ }^{171}$, com duas naturezas - humana e divina — numa só.

HÉRACLES - Não é verdade que todos vós, filósofos, acreditais que somos compostos de duas partes, alma e corpo? Portanto, que é que impede que a alma, que é proveniente de Zeus, esteja no céu, enquanto a parte mortal, eu aqui, esteja entre os mortos?

5] DiÓGENES - Ó meu caro Anfitriónides ${ }^{172}$, estarias a falar muito acertadamente, se fosses corpo... mas agora és apenas um simulacro incorpóreo, pelo que corres o risco de ter criado um triplo Héracles.

HÉRACLES - Triplo, como?

${ }^{169}$ Esta expressão, dirigida a Héracles, tem graça. O texto grego diz, literalmente, "por ti, Héracles!».

${ }^{170}$ Recorde-se que Héracles nasceu da relação de Zeus com Alcmena, esposa de Anfitriāo, rei de Tebas, enquanto este estava fora, na guerra.

${ }^{171}$ hipocentauro: figura mitológica, metade cavalo e metade homem. A comparação com natureza humana e divina é, pois, só parcial.

172 Anfitriónides, "filho (ou da família) de Anfitrião" é mais uma "farpa» lançada pelo cínico Diógenes. 
DIÓGENES - Do seguinte modo: se um deles está no céu, e o outro, um simulacro, que és tu, está entre nós, e o corpo está no monte Eta ${ }^{173}$, já transformado em cinza, tudo somado, dá três... Vê lá bem que pai imaginarás para este corpo.

HÉRACLES - És um atrevido e um sofista. Mas... afinal, quem és tu?

DiÓGENES - Sou o simulacro de Diógenes de Sinope. Eu propriamente, porém, por Zeus!, não estou "com os deuses imortais", mas, na companhia dos melhores de entre os mortos, rio-me de Homero e de disparates quejandos.

${ }^{173}$ Local onde Héracles se imolou pelo fogo e de onde, já purificado, subiu ao Olimpo e passou a fazer parte da comunidade dos deuses celestes... 
(Página deixada propositadamente em branco) 


\section{Menipo E TÂNTALO ${ }^{174}$}

1] MENIPO - Porque estás a chorar, ó Tântalo? Porque te lamentas, postado à beira do lago?

TÂNTALO - É que estou a morrer de sede, Menipo.

MENIPO - És assim tão indolente, que não te baixas para beber, ou entấo, por Zeus!, para recolher água na concha da mão?

TÂNTALO - Não ganharia nada em baixar-me, pois a água, mal sente que me aproximo, escapa-se; e se por acaso a recolho e a aproximo da boca, não chego sequer a molhar a ponta dos lábios, pois a água, não sei lá como, escapa-se-me por entre os dedos e deixa-me a mão seca.

MENIPO - É espantoso o que se passa contigo, ó Tântalo. Mas... diz-me cá: porque é que precisas de beber? Na verdade, não tens corpo, pois esse, que podia ter fome e sede, está sepultado algures na Lídia. Tu, porém, isto é, a tua alma, como é que ainda poderias ter sede ou beber?

TÂNTALO - A minha punição consiste precisamente nisso: que a alma tenha sede, como se fosse corpo.

2] MENIPO - Bem... admitamos que assim é, já que és tu que dizes que o teu castigo consiste em sentir sede. Mas que mal tem isso? Será que receias morrer por falta de água? $\mathrm{Na}$ verdade, não vejo outro Hades depois deste, nem outra morte que nos leve daqui para outro lugar.

TÂNTALO - Dizes bem. Isto de desejar beber sem ter necessidade faz parte da minha condenação.

MENIPO - Ó Tântalo, estás a delirar, e, na verdade, parece que precisas de uma bebida, e mesmo, por Zeus!, de eléboro ${ }^{175}$ puro, pois passa-se contigo o contrário do que sucede com as pessoas que são mordidas por cães raivosos: tens horror, não à água, mas à sede.

TÂNTALO - Ó Menipo, eu não me recuso a tomar eléboro: oxalá mo dessem!

MENIPO - Tem coragem, Tântalo, pois nem tu nem qualquer outro de entre os mortos o beberá: isso é impossível. Em

${ }^{174}$ Tântalo é um dos grandes supliciados da mitologia. Cortou em pedaços o corpo de Pélops e ofereceu-o aos deuses num banquete sacrílego, o que lhe valeu a punição a que se refere o texto do diálogo.

${ }_{175} \mathrm{O}$ eléboro é uma planta a que se atribuía a propriedade de curar a loucura (v. diálogo 13, 6 . 
boa verdade, nem todos, como tu, e por castigo, estão sequiosos de uma água que não espera por eles. 


\section{Menipo e HeRmeS}

1] MENIPO - Ó Hermes, mas onde é que estão os belos e as belas? Guia-me lá, pois acabo de chegar.

HERMES - Não tenho vagar, Menipo. Mas olha naquela direcção, ali para a direita, onde estão Jacinto ${ }^{176}$, Narciso, Nireu, Aquiles, Tiro, Helena, Leda, enfim, todas as beldades antigas.

MENIPO - Só vejo ossos e caveiras, despojados de carne e na sua maioria todos iguais.

HERMES - E no entanto, é isso o que todos os poetas louvam, esses ossos que tu pareces desprezar.

MENIPO - Mesmo assim, mostra-me Helena, pois eu, só por mim, não seria capaz de a identificar.

HERMES - Esta caveira... é Helena.

2] MENIPO - Então foi por causa disto que foram equipados milhares de navios vindos de toda a Grécia e que morreram tantos Gregos e bárbaros e tantas cidades foram arrasadas?!

HERMES - É que tu, Menipo, não viste a mulher quando ela era viva, pois então também tu dirias que não seria censurável "por esta mulher afrontar padecimentos longamente» ${ }^{177}$. É como as flores, as quais, quando as vemos murchas e com a cor perdida, nos parecem claramente feias, mas que, quando estão viçosas e mantêm a sua cor, são formosíssimas.

MENiPO - Justamente, ó Hermes, o que me espanta é o facto de os Aqueus náo terem compreendido que estavam a sofrer por uma coisa tão efémera e estiolável.

HERMES - Bem, Menipo, não tenho vagar para filosofar contigo. Portanto, escolhe um sítio que te apeteça, estende-te ao comprido e fica por lá, que eu vou já daqui procurar outros mortos.

${ }^{176}$ Jacinto, amado por Apolo, foi morto por um disco lançado pela máo de Apolo, que Zéfiro, por ciúme, fizera desviar da sua trajectória; foi transformado na flor com o seu nome. Narciso era um formoso jovem, que se apaixonou pela sua própria imagem reflectida na água. Nireu era o mais belo dos gregos, depois de Aquiles. Tiro, e Leda são beldades femininas, amadas, respectivamente, por Posídon e Zeus; Helena, a belíssima esposa de Menelau, raptada por Páris e levada para Tróia, foi a causa da guerra de Tróia... mas considerem-se outras interpretaçóes no diálogo 19.

${ }^{177}$ Citação de Homero, Ilíada, III, 157. 
(Página deixada propositadamente em branco) 


\section{9. ÉaCO ${ }^{178}$ E Protesilau ${ }^{179}$}

1] ÉACO - Ó Protesilau, porque é que te lanças sobre Helena no intuito de a estrangular?

Protesilau - Porque foi por causa dela, ó Éaco, que eu morri, deixando a minha casa meia acabada e viúva a minha esposa recém-casada.

ÉACO - Nesse caso, acusa antes Menelau, que nos levou a Tróia por causa de tal mulher.

PROTESILAU - Dizes bem: é a esse que devo acusar.

MENELAU - A mim não, meu caro, mas mais justamente a Páris, que, contra todos os princípios da justiça, raptou a esposa do seu hospedeiro, que era eu. Na verdade, Páris é que merecia ser estrangulado, não apenas por ti, mas por todos os Gregos e Bárbaros, visto ter sido ele o responsável pela morte de tantos homens.

Protesilau - Assim é melhor. Portanto, maldito Páris, nunca te largarei da mão.

PÁRIS - Ó Protesilau, estás a ser injusto, tanto mais que sou da mesma arte ${ }^{180}$ que tu: sim, eu também sou um apaixonado e estou possuído pelo mesmo deus... e tu bem sabes como ele é algo de irresistível, uma força divina que nos conduz para onde entender, e contra quem é impossível resistir.

2] Protesilau - Dizes bem. Quem me dera que fosse possível apanhar aqui Eros ${ }^{181}$.

ÉACO — Eu vou dar-te a justa resposta, em nome de Eros. Na verdade, Eros dir-te-á que ele mesmo é talvez o responsável pela paixão de Páris, mas que da tua morte, ó Protesilau, ninguém é culpado, a não ser tu próprio, uma vez que, esquecendo-te da tua esposa recém-casada, quando do assalto a Tróia, saltaste à frente dos outros com completo desprezo pelo perigo e com

${ }^{178}$ Éaco é, juntamente com Minos e Radamanto, um dos juízes do Inferno.

${ }^{179}$ Protesilau foi o primeiros grego que morreu junto das muralhas de Tróia.

${ }^{180}$ Trata-se da «arte» de amar...: também sou amador, como tu.

${ }^{181}$ Eros (Cupido, Amor), «de aljava bem guarnecida, era um menino travesso e malicioso, que pregava partidas nem sempre inocentes. De cada vez que lançava uma seta do seu arco infalível, o amor implantava-se num coração e aí reinava como um tirano" (v. A.-M. Guillemin, Récits mythologiques, Paris, Hatier, 2a ed. 1936, p. 67). 
grande imprudência, movido pelo amor da glória, devido à qual foste o primeiro a morrer, quando do desembarque.

PROTESILAU — Então agora, ó Éaco, vou dar-te uma resposta mais justa em minha defesa. De facto, não sou eu o culpado desta desgraça, mas sim a Moira ${ }^{182}$, que desde o princípio assim fiou o meu destino.

ÉACO — Está certo... Mas então porque acusas estas pessoas?

${ }^{182}$ As Moiras (ou Parcas), filhas de Zeus e de Témis (a Justiça), eram as divindades que presidiam ao destino dos humanos. Eram três: Cloto, Láquesis e Átropo. Láquesis determinava a parte de vida que cabia a cada pessoa e carregava a roca, que depunha nas mãos de Cloto; Átropo, ao cortar o fio, punha termo aos dias de vida concedidos. Aqui, o singular, a Moira, deve referir-se a Cloto, a «fiandeira». 


\section{Menipo E ÉaCo}

1] MENIPO — Por Plutão ${ }^{183}$, ó Éaco, leva-me a ver tudo o que existe no Hades.

ÉACO - Mesmo tudo, ó Menipo, não é lá muito fácil. Mas fica a conhecer pelo menos o essencial... Que este aqui é Cérbero $^{184}$, já tu sabes; também conheces o barqueiro que te passou; e já viste, ao entrar, o lago e o [rio] Piriflegetonte ${ }^{185}$.

MENIPO - Isso conheço eu, e a ti, que és o porteiro; também vi o rei e as Erínias ${ }^{186}$. Mas o que eu quero que me mostres sáo os homens de antigamente, sobretudo os mais famosos de entre eles.

ÉACO - Este aqui é Agamémnon ${ }^{187}$, este é Aquiles, este aqui ao lado é Idomeneu, este é Ulisses, depois estão Ájax e Diomedes e os mais nobres de entre os gregos.

2] MENiPO - Ó Homero! Como os chefes das tuas rapsódias estão prostrados por terra, irreconhecíveis e informes, reduzidos a pó, coisas insignificantes, caveiras verdadeiramente inconsistentes! Ora então, ó Éaco, quem é este aqui?

ÉACO - É Ciro; e este é Creso, e este a seu lado é Sardanapalo, e ao lado dele está Midas, e aquele além é Xerxes.

MENIPO - Então foi diante de $\mathrm{ti}^{188}$, monte de porcaria, que a Grécia tremeu, ao tentares ligar o Helesponto e pretendendo navegar através das montanhas? Vejam em que estado está Creso! Ó Éaco, permite-me que dê um murro na cara de Sardanapalo.

183 Por Plutão é a leitura de alguns manuscritos e de quase todos os editores modernos, que também segui, em vez da lição de outros manuscritos e da edição de Mras.

${ }^{184}$ Cérbero é o cão de guarda do reino de Hades; é geralmente representado com três cabeças.

${ }^{185} \mathrm{O}$ Piriflegetonte, um dos rios do Inferno, tem ondas de fogo e exala um forte cheiro a enxofre.

${ }^{186}$ As Erínias (ou Fúrias) eram três: Tisífine, Alecto e Megera. «Vestidas de negro, com asas nos ombros, estas sinistras vigilantes percorriam silenciosamente o espaço e mostravam-se ao malfeitor coroadas de serpentes, enquanto a lembrança do crime lhe roía o coração... (v. A.-M. Guillemin, Récits mythologiques, Paris, Hatier, 2a ed. 1936, p. 191).

${ }^{187}$ Agamémnon foi o comandante supremo da expedição contra Tróia.

188 Refere-se concretamente a Xerxes. 
ÉACO - De maneira nenhuma, pois quebrar-lhe-ias a caveira, que é de mulher.

MENIPO - Nesse caso, pelo menos vou mandar-lhe uma escarradela, já que ele é andrógino ${ }^{189}$.

3] ÉACO - Queres que te mostre também os sábios?

MENIPO — Sim, por Zeus!

ÉACO - Este aqui, o primeiro, é Pitágoras.

MENIPO - Salve, ó Euforbo ${ }^{190} \ldots$ ou Apolo... ou lá o que queiras ser!

PITÁGORAS - Salve para ti também, Menipo.

MENIPO - Então já não tens a coxa de ouro?

PITÁGORAS - Não... Mas... deixa ver se tens aí no saco alguma coisa que se coma.

MENIPO - Favas, meu caro! Náo é coisa que tu possas comer ${ }^{191}$.

PITÁGORAS - Vá lá, dá-me! Entre os mortos, as crenças são outras: na verdade, aprendi que aqui não há nada de comum entre favas e cabeças dos nossos pais ${ }^{192}$.

4] ÉACO - E este é Sólon, filho de Execéstides... e aquele além é Tales, e ao lado deles está Pítaco e outros: são sete ao todo, como vês ${ }^{193}$.

MENIPO - De entre todos, ó Éaco, estes são os únicos livres de tristeza e jubilosos... E aquele coberto de cinza, como um pão cozido sob as cinzas, aquele salpicado de pústulas... quem é? ÉACO - É Empédocles, Menipo... chegou do Etna meio cozido. MENIPO - O caríssimo "pé-de-bronze», porque é que te lançaste na cratera?

EMPÉDOCLES - Ó Menipo, foi uma espécie de melancolia. MENIPO - Não foi, não, por Zeus!, mas antes a vanglória, o orgulho e muita estupidez, isso é que te reduziu a carvão,

${ }^{189}$ A palavra andrógino significa «homem-mulher», logo, «homem efeminado".

${ }^{190}$ Euforbo, guerreiro troiano morto por Menelau. Pitágoras afirmava ser uma sua reincarnação.

${ }^{191}$ Entre diversas proibiçóes no que respeita a alimentos, contam-se as favas, peixe e ovos, por motivos ligados à crença na metempsicose.

192 Estas conversa de favas alude à proibição, entre os pitagóricos, de ingerir tal alimento, pois nele podiam introduzir-se almas de pessoas...

${ }^{193}$ Luciano, através de Éaco, menciona somente os três sábios mais conhecidos e mais consensuais (Sólon, Tales e Pítaco). 
mais as tuas sandálias... e não deixaste de o merecer. Todavia, de nada te valeu o truque, pois houve quem te visse já morto... Mas... e o Sócrates, ó Éaco, onde está ele?

ÉACO - Esse está quase sempre tagarelando com Nestor e Palamedes.

MENIPO - Em todo o caso, desejava vê-lo, se é que está por aí. ÉACO - Estás a ver aquele calvo?

MENIPO - Mas são todos calvos... Esse sinal é comum a todos.

ÉACO - Refiro-me ao do nariz achatado.

MENIPO - Também isso é igual, pois todos têm nariz achatado.

5] SÓCRATES - Andas à minha procura, ó Menipo?

MENIPO - Ando, sim, ó Sócrates.

SÓCRATES - Como vão as coisas em Atenas?

MENIPO - Muitos jovens dizem filosofar, e de facto, a julgar pela pose e modo de andar, são filósofos de alto gabarito.

SÓCRATES - Tenho visto muitos assim.

MENIPO - Também viste, creio eu, em que estado aqui chegaram Aristipo ${ }^{194}$ e o próprio Platão, aquele cheirando a perfume, e este habituado a cortejar os tiranos na Sicília.

SÓCRATES - E de mim... que é que as pessoas pensam?

MENIPO - Pelo menos nesse ponto, ó Sócrates, és uma pessoa feliz, pois todos acham que foste um homem admirável, que sabia tudo, embora — julgo que há que dizer a verdade - nada sabendo ${ }^{195}$.

SÓCRATES - Eu próprio lhes dizia e repetia isso, mas eles cuidavam que era por ironia.

6] MENIPO - E quem são estes aqui à tua volta?

SÓCRATES - É Cármides, ó Menipo, e Fedro, e o filho de Clínias ${ }^{196}$.

${ }^{194}$ Aristipo, discípulo de Sócrates e fundador das escola de Cirene (na Líbia), ou cirenaica, ou hedonística, que defende que a felicidade reside no prazer. Já se compreende a alusão ao perfume. No que respeita a Platão, Menipo não deixa de mencionar as relaçôes com os tiranos da Sicília.

${ }^{195}$ Referência à conhecida e repetida frase de Sócrates: «eu só sei que nada seimm.

${ }^{196}$ O filho de Clínias é Alcibíades (450-404 a.C), sobrinho de Péricles, personagem muito controversa, à qual, segundo os seus adversários, de nada valeram as liçōes de Sócrates. 
MENIPO - Bravo, ó Sócrates, pois até mesmo aqui te ocupas da tua arte e não desprezas os belos moços ${ }^{197}$.

SÓCRATES - Que outra coisa mais agradável poderia fazer? Ora bem, deita-te aqui ao nosso lado, se isso te apraz.

MENIPO - Não, por Zeus!, pois tenho de ir para junto de Creso e de Sardanapalo, para residir perto deles. Parece-me bem que vou rir, e não pouco, ao ouvir as suas lamentaçóes.

ÉACO - Pois eu vão já vou indo, não se dê o caso de algum morto se me escapar sem eu dar por isso. Para a outra vez verás o resto, ó Menipo.

MENIPO - Vai, sim, Éaco, que por agora já basta.

${ }^{197}$ A referência à arte (ars amatoria) e aos belos moços sugerem, subtilmente, uma prática pederástica de Sócrates, o qual, pelo menos, da fama não se livrou, por muito injusta que seja a alusão. 


\section{Menipo e Cérbero}

1] MENIPO - Ó Cérbero - sim, eu sou teu parente, pois também sou "cão» ${ }^{198}$, diz-me cá, pelo Estige! ${ }^{199}$, que aspecto tinha Sócrates, quando desceu até vós. É natural que tu, sendo uma divindade, não te limites a ladrar, mas que também fales como os humanos, sempre que quiseres.

CÉRBERO - Visto de longe, ó Menipo, parecia avançar de rosto impávido, com aspecto de quem não temia absolutamente nada a morte ${ }^{200}$ e querendo mostrar isso mesmo aos que se encontravam no exterior da entrada para aqui. Quando, porém, se inclinou para dentro do abismo e viu as trevas, e ainda por cima eu o mordi e o arrastei por um pé, pelo facto de ele se demorar por efeito da cicuta ${ }^{201}$, berrava como um bebé, chorava pelos seus filhinhos e fazia-se de todas as cores ${ }^{202}$.

2] MENIPO - Quer dizer que o homem era um autêntico sofista ${ }^{203}$, para quem essa coisa [da morte] não era indiferente?!

CÉRBERO - Não... mas quando viu que, de qualquer modo, a morte era inevitável, fazia-se forte, como se fosse sofrer de boa vontade aquilo que, de toda a maneira, tinha de sofrer, só para que os assistentes o admirassem. E o mesmo, em geral, poderia dizer a respeito de todos nesta situação: até aqui à entrada, são ousados e viris, mas, uma vez cá dentro, mostram aquilo que são.

MENIPO - E eu... como é que te pareci ao descer?

CÉRBERO - Tu, Menipo, foste o único digno da tua raça... bem como Diógenes antes de ti, porquanto, viestes sem serdes obrigados ou empurrados, mas de bom grado, rindo e praguejando contra todos.

${ }^{198}$ Menipo é um filósofo cínico, gr. kynikós, «relativo a cão», "canino».

${ }^{199}$ Um dos rios do Inferno.

${ }^{200}$ Aqui segui a ed. Loeb, num passo em que os manuscritos divergem.

${ }^{201}$ A cicuta é uma planta apiácea tóxica. Além de ser usada como terapèutica externa, servia também como modo de suicídio e em condenaçóes à morte. Pela descrição de Platão, o seu efeito começava nas pernas e ia subindo mais ou menos lentamente até ao coração, sem provocar sofrimento.

202 "Fazia-se de todas as cores" é tradução do Prof. Costa Ramalho.

${ }^{203}$ A aplicação do termo sofista a Sócrates é realmente bastante forte, pois Sócrates e os sofistas estavam em campos opostos... mas a comparação náo deixa de ter algum fundamento... 
(Página deixada propositadamente em branco) 


\section{Caronte e Menipo}

1] CARONTE - Paga a passagem, maldito!

MENIPO - Ó Caronte, berra, se isso te é mais agradável.

CARONTE - Paga — repito - a quantia por que te passei.

MENIPO - Não poderias receber de quem não tem.

CARONTE - Mas há alguém que não tenha um óbolo?

MENIPO - Se há alguém, não sei... eu é que não tenho.

CARONTE - Pois então, por Plutão!, vou esganar-te, maldito, se não me pagares.

MENIPO - E eu bato-te com o cajado, que até te racho o crânio.

CARONTE - Será que fizeste em vão uma tal viagem?

MENIPO - Hermes que te pague por mim, já que foi ele que me trouxe junto de ti.

2] HERMES - Por Zeus!, estava bem arranjado, se tivesse de pagar pelos mortos.

CARONTE - Não te largarei.

MENIPO - Nesse caso, póe o barco em seco e vai esperando. Mas como poderias receber o que eu não tenho?

CARONTE - Então não sabias que era preciso trazer [o óbolo]?

MENIPO - Sabia, pois, mas não tinha. Então e lá por isso não devia morrer?

CARONTE - Serás tu o único a gabar-se de ter feito a travessia de graça?

MENIPO - De graça, não, meu caro, pois esvaziei a água, ajudei ao remo e fui o único, de entre todos os passageiros, que não chorei.

CARONTE - Isso não interessa ao barqueiro. Tens é de pagar o óbolo, não pode ser de outro modo.

3] MENIPO - Nesse caso, leva-me de novo para a vida.

CARONTE - Tens cá uma graça... Para levar pancada de Éaco por causa disso...

MENIPO - Então não me chateies.

CARONTE - Mostra cá o que tens no saco.

MENIPO - Tremoços, se quiseres, e o jantar de Hécate ${ }^{204}$.

${ }^{204}$ Hécate, deusa infernal, venerada nas encruzilhadas, protectora das bruxas, por vezes associada à Lua. Os mortos acalmavam a sua ira, 
CARONTE - Ó Hermes, onde foste desencantar este cão? Que coisas ele palrava durante a viagem, rindo e troçando de todos os passageiros e o único que cantava, enquanto aqueles gemiam.

HERMES - É que tu, ó Caronte, desconheces que homem passaste: um homem completamente livre, que não se preocupa com coisa nenhuma. Este é o Menipo!

CARONTE - Seja como for, se alguma vez te apanhar...

MENIPO - Se apanhares, meu caro. Não poderás apanhar-me duas vezes.

levando-lhe o «jantar de Hécate», a que aqui se faz referência. 


\section{Plutão e Protesilau ${ }^{205}$}

1] Protesilau - Ó meu Senhor e meu rei ${ }^{206}$, e tu, nosso Zeus, e tu, filha de Deméter ${ }^{207}$, não rejeiteis a súplica de um amoroso.

Plutấ - Que é que tu nos pedes? E quem és tu?

Protesilau - Sou Protesilau filho de Ificlo, de Fílace, soldado aliado dos Aqueus e o primeiro a morrer junto de Ílion ${ }^{208}$. Rogo-vos que me concedais uma curta licença para voltar de novo à vida.

PLUTÃO - Ó Protesilau, essa paixão atinge todos os mortos, mas nenhum deles consegue concretizá-la.

Protesilau - Mas eu, ó Aidoneu ${ }^{209}$, não estou apaixonado pela vida, mas por minha esposa, que, ao fazer-me ao mar, deixei recém-casada no leito nupcial. Depois, por minha desgraça, morri ao desembarcar, às mãos de Heitor. Por isso, meu Senhor, o amor por minha esposa está-me torturando, e náo é pouco, pelo que desejo que ela me veja, ainda que por pouco tempo, e depois eu volto novamente para cá.

2] Plutão - Ó Protesilau, não bebeste a água do Lete ${ }^{210}$ ?

Protesilau - Muito, meu Senhor, mas o tormento era enorme.

PlUTÃo - Nesse caso, vai esperando, pois também ela, um dia, há-de cá chegar, pelo que não precisarás de ir lá acima.

Protesilau - Mas, ó Plutão, não suporto a demora. Tu também já estiveste apaixonado ${ }^{211}$, pelo que sabes quanto custa amar.

PLUTÃO - Mas então de que te servirá reviver durante um dia, se pouco depois sofres as mesma dores?

205 Ver diálogo 19.

206 Refere-se, naturalmente, a Plutão (Hades), senhor do reino dos mortos.

${ }^{207}$ A filha de Deméter é Perséfone (Prosérpina), esposa de Plutão, junto do qual passa seis meses por ano, e os outros seis meses na companhia da mãe, na terra.

208 Ílion = Tróia.

${ }^{209}$ Aidoneu é outra designação de Hades ou Plutão.

${ }^{210}$ A água do Lete é a "água do esquecimento».

${ }^{211}$ De facto, Plutão raptou Perséfone (Prosérpina), filha de Deméter, e levou-a para o seu reino, o reino dos mortos, onde, porém, ela só passa seis meses por ano (v. nota supra). 
PROTESILAU - Creio poder convencê-la a acompanhar-me para junto de vós, de modo que, dentro de pouco tempo, receberás dois mortos em vez de um só.

PlUTÃo - Não é lícito que tal coisa ocorra... nem nunca ocorreu $^{212}$.

3] Protesilau - Vou avivar-te a memóriaa ${ }^{213}$, Plutão. $\mathrm{Na}$ verdade, por esta mesmíssima razão vós entregastes Eurídice a Orfeu e deixastes partir a minha parente Alceste, para agradar a Héracles.

PLUTÃO - Mas quererás tu aparecer a essa tua linda noiva assim de crânio nu e sem beleza? Como é que ela te acolherá, se nem sequer é capaz de te reconhecer? Na verdade - estou certo - ficará aterrorizada e fugirá de ti, pelo que terás feito em vão uma táo grande caminhada.

PERSÉFONE - Nesse caso, meu esposo, remedeia tu a situação e ordena a Hermes que, mal Protesilau esteja à luz do dia, lhe toque com a vara e assim o transforme imediatamente num belo moço, tal como ele era ao sair do leito nupcial.

PlUTÃo - Uma vez que é essa a opinião de Perséfone, leva-o ${ }^{214}$ lá para cima e transforma-o num noivo. E tu lembra-te de que só tens um dia.

212 Aqui os manuscritos divergem um pouco, mas a ideia é clara.

${ }^{213}$ Protesilau menciona dois precedentes de derrogaçáo às leis da morte, em que os deuses infernais permitiram que duas humanas regressassem à vida terrena.

${ }^{214}$ É óbvio que Plutão se dirige a Hermes, e logo a seguir a Protesilau. 


\section{Diógenes e Mausolo ${ }^{215}$}

1] DiÓGENES — Ó cário, porque é que estás tão orgulhoso e te julgas digno de mais honrarias que todos nós?

MAUSOLO - Antes de mais, ó sinopense ${ }^{216}$, pela minha realeza, por ter sido rei de toda a Cária, por ter governado alguns Lídios, por ter submetido certas ilhas e por ter chegado até Mileto, devastando a maior parte da Jónia. Em segundo lugar, por ser belo, de elevada estatura e valente nas guerras. Mas a coisa mais importante é o facto de ter deixado em Halicarnasso um monumento enorme, como o de nenhum outro morto, nem tâo trabalhado com tanta beleza, com representações exactas de cavalos e homens feitos da mais bela pedra, de tal modo, que não é fácil de encontrar nem sequer um templo assim. Não achas que é com razão que estou tão orgulhoso?

2] DiÓGENES - Referes-te à tua realeza, à tua formosura e à magnificência do teu túmulo?

MAUSOLO - Sim, por Zeus!, a tudo isso.

DIÓGENES - Mas... ó belo Mausolo, tu já não possuis nem essa força nem essa beleza. Certamente que, se escolhêssemos um juiz que julgasse a beleza, não posso dizer por que razão o teu crânio haveria de valer mais que o meu. Realmente, ambos os crânios são calvos e nus, temos ambos os dentes igualmente salientes, estamos privados de olhos e temos os narizes achatados. Quanto ao túmulo e a essas pedras caríssimas, talvez os Halicarnassenses os achem dignos de serem mostrados e admirados pelos estrangeiros, como grande construção que constituem. Mas tu, meu caro, não sei que é que ganhas com isso, a não ser o facto de dizeres que estás mais sobrecarregado que nós, esmagado ao peso de táo grandes pedras.

3] MaUsOlO - Então todas essas coisas me são inúteis, e Mausolo será igual a Diógenes?

${ }^{215}$ Mausolo, rei da Cária (costas da Ásia Menor). Quando morreu, Artemísia, sua esposa e irmá, mandou erigir na capital, Halicarnasso, em sua honra e memória, um grandioso monumento, um "mausoléu», que os antigos consideravam uma das sete maravilhas do mundo. A designaçáo Mausoléu passou a aplicar-se a outros monumentos funerários de grande espavento.

${ }^{216}$ Sinopense $=$ natural de Sinope, cidade da Paflagónia (Ásia Menor). 
DIÓGENES - Igual, isso não, mui nobre senhor ${ }^{217}$, pois Mausolo lamentar-se-á, recordado dos bens que deixou na terra, com os quais se julgava feliz, enquanto Diógenes troçará dele; Mausolo falará do seu túmulo em Halicarnasso, mandado erigir por Artemísia, sua mulher e irmã, ao passo que Diógenes nem sequer sabe se existe algum túmulo a cobrir o seu corpo, pois isso era coisa que não o preocupava, mas antes, depois de viver uma vida de autêntico homem, deixou às pessoas de bem uma reputaçáo de si próprio muito mais alta, ó mais vil dos escravos cários, do que o teu monumento, reputaçáo essa erigida em terreno mais firme.

${ }^{217}$ Naturalmente, há nesta designação («nobilíssimo») muita ironia. 


\section{NireU ${ }^{218}$, Tersites E MeNiPO}

1] NiREU - Ora aí está! Aqui o Menipo é que vai decidir qual de nós dois é mais formoso? Diz lá, ó Menipo: não te pareço mais belo?

MENIPO - Mas quem sois vós? Antes de mais, julgo eu, é preciso saber isso.

NIREU - Nireu e Tersites.

MENIPO - E qual é o Nireu, e qual o Tersites? É que isso também não é óbvio.

TERSITES - Uma coisa já eu consegui: que sou igual a ti e que não diferes de mim nas qualidades que o ilustre cego ${ }^{219}$, Homero, tanto gabava em ti, ao chamar-te o mais belo de todos; mas, pelo contrário, eu, o cabeça-de-melão, o calvo, não pareci nada inferior aos olhos do juiz. Ora vê lá bem, ó Menipo, qual de nós consideras mais formoso.

NIREU - A mim, certamente, o filho de Aglaia e de Cárope,

"o mais formoso guerreiro, que vim sob os muros de Tróia $"^{\mathbb{}}$.

2] MENIPO - Mas não o mais formoso, segundo creio, a vir para debaixo da terra; pelo contrário, os vossos ossos são idênticos, e o crânio difere num único ponto do crânio de Tersites: o teu é quebradiço, sim, muito mole e nada viril.

NIREU - No entanto, pergunta a Homero como é que eu era, quando fazia parte do exército dos Aqueus.

MENIPO - Estás a sonhar! O que eu vejo é o teu estado actual, e quanto a essas fantasias, conhecem-nas os de outrora.

NIREU — Quer dizer, ó Menipo, que, aqui, não sou o mais formoso?

MENIPO - Nem tu és formoso, nem qualquer outro, pois no Hades reina a igualdade de direitos e são todos iguais.

TERSITES - Isso é quanto me basta.

${ }^{218}$ Entre os guerreiros gregos da expedição contra Tróia, Nireu era o mais belo, a seguir a Aquiles, e Tersites o mais feio. Só no reino de Hades seria possível este concurso de... beleza.

${ }^{219}$ A referência à cegueira de Homero é realmente impiedosa, tratando-se de atribuir formosuras e fealdades... 
(Página deixada propositadamente em branco) 


\section{Menipo e QUíroN ${ }^{220}$}

1] MENIPO - Ó Quíron, ouvi dizer que tu, apesar de seres deus, quiseste morrer.

QUíRON - É verdade o que ouviste, ó Menipo; e, como vês, estou morto, podendo ser imortal.

MENIPO - Mas então que paixão pela morte se apoderou de ti, uma coisa que a generalidade das pessoas abomina?

QUíRON - Vou dizer-te, mas só a ti, que não és tolo: é que deixou de me ser agradável gozar da imortalidade.

MENIPO - Náo te era agradável viver e ver a luz do dia?

QUíRON - Não, Menipo. De facto, eu pelo menos considero que o que é agradável é algo de variado e não simples, pelo que, ao viver perpetuamente e a gozar sempre das mesmas coisas, como o sol, a luz, a comida (e até as estaçôes eram sempre as mesmas, e os acontecimentos surgiam todos de enfiada, como seguindo-se uns aos outros)... fartei-me de tudo isso. $\mathrm{Na}$ verdade, o prazer consiste, não na constante repetição do mesmo, mas na mudança.

MENIPO - Dizes bem, Quíron... Mas agora... como suportas as coisas aqui no Hades, já que foi por opção tua que vieste para cá?

2] QUíRON — Não desagradavelmente, Menipo. De facto, a igualdade de direitos é muito democrática, e não há diferença nesta coisa de estar à luz do dia ou na escuridão. De resto, náo há que ter sede ou ter fome, como lá em cima, mas estamos livres de tudo isso.

MENIPO - Vê lá bem, Quíron, não te contradigas e que o teu argumento caia nos termos anteriores.

QUÍRON - Porque dizes isso?

MENIPO - Porque, se a monotonia das coisas da vida, constante e sempre a mesma, acabou por te saturar, então também as coisas daqui, monótonas como são, te hão-de igualmente saturar, e precisarás de procurar uma qualquer mudança daqui para uma outra vida - coisa que considero impossível.

QUÍRON - Então que havemos de fazer, ó Menipo?

${ }^{220}$ Quíron é um centauro, ou melhor, um hipocentauro, meio homem e meio cavalo. Especialista, entre outras artes, em música e medicina. 
MENIPO - Aquilo - creio eu — que sói dizer-se: que é um acto de bom senso contentarmo-nos com aquelas coisas que temos, estimá-las e não considerar nenhuma delas insuportável. 


\section{AntísteneS ${ }^{221}$, Crates E Diógenes}

1] DiÓGEnES - Antístenes e Crates, não temos nada que fazer; então porque não vamos até além à descida, para passearmos e observarmos os que descem e vermos que espécie de pessoas são e como cada uma delas se comporta.

ANTÍSTENES - Vamos, sim, Diógenes. De facto, será um espectáculo divertido ver alguns deles chorando, outros, suplicando que os libertem, uns quantos descendo muito a custo e fazendo marcha-atrás, ainda que Hermes os empurre pelo pescoço, e eles resistindo, deitados no chão — resistência inútil.

CRATES - Também eu vos contarei o que vi, quando vinha pela rampa abaixo.

DIÓGENES - Sim, Crates, conta lá, pois parece que vais dizer coisas mui dignas de riso.

2] CRATES - Eram muitos os que desciam juntamente comigo, entre os quais gente importante, como o ricaço Ismenodoro, meu compatriota, Arsaces, governador da Média, e o arménio Oretes. Ora, Ismenodoro (que fora assassinado por salteadores na região do Citéron, quando - presumo — se dirigia para Elêusis) lamentava-se, com ambas as mãos agarradas à ferida, chamava pelos filhos, que deixara abandonados de tenra idade, e censurava-se pela sua temeridade, por atravessar o Citéron e viajar por Elêuteras - região completamente deserta devido às guerras - acompanhado apenas dois criados, e isto apesar de levar consigo cinco vasos de ouro e quatro taças... [3] Quanto a Arsaces, já velho, mas, por Zeus!, de aspecto venerável, sofria à maneira dos bárbaros, mostrava-se indignado pelo facto de caminhar a pé e exigia que lhe trouxessem o cavalo. E realmente, o cavalo tinha morrido juntamente com ele, quando ambos foram varados por um só golpe desferido por um peltasta ${ }^{222}$ trácio, num recontro com o chefe capadócio, nas margens do Araxe. De facto, Arsaces, como ele próprio contava ${ }^{223}$, avançara, atacando muito à frente dos outros, quando o trácio, esperando-o a pé firme e cobrindo-se com o escudo, fez saltar

${ }^{221}$ Três filósofos cínicos: Antístenes, fundador da Escola, e Diógenes e Crates, seus sucessores.

222 Os peltastas eram soldados de infantaria ligeira, que usavam um pequeno escudo redondo, pelte, donde a designaçáo.

${ }^{223}$ Naturalmente, já na rampa dentro do Hades. 
a lança de Arsaces e, metendo a sua lança por baixo, atravessou, bem como ao cavalo.

4] Antístenes - Ó Crates, como foi possível fazer isso com um único golpe?

CRATES - Muito facilmente, Antístenes. De facto, Arsaces avançou de lança em riste, uma lança para aí de vinte côva$\operatorname{dos}^{224}$, mas o trácio desviou a arma com o escudo, pelo que a ponta da lança lhe passou ao lado; então, dobrando um joelho, recebe com a sua lança o ataque de Arsaces e fere em pleno peito o cavalo, que se trespassou a si próprio devido ao ardor e impetuosidade. Arsaces, por seu lado, é varado de lado a lado, das virilhas até às nádegas. Já vês como tudo aconteceu, que não foi obra do homem, mas mais propriamente do cavalo. Mesmo assim, Arsaces estava irritado por ter honras iguais aos outros mortos, e exigia descer a rampa a cavalo... [5] Finalmente Oretes era tão delicado de pés, que nem sequer era capaz de se ter de pé, e muito menos caminhar, o que é uma característica geral de todos os Medos: sempre que desmontam do cavalo, andam com muita dificuldade, nas pontas dos pés, como se andassem sobre espinhos... de modo que, deitando-se no chão, ali ficou, náo querendo de maneira nenhuma levantar-se, pelo que foi o bom do Hermes que o levantou e o levou até ao barco, enquanto eu não fazia senão rir.

6] Antístenes - No meu caso, ao descer a rampa, não me misturei com os outros, mas deixando-os a lamentarem-se, corri para o barco e arranjei lugar antes deles, para fazer a viagem comodamente. Durante a travessia, uns choravam e outros vomitavam, enquanto eu me divertia à brava à sua custa.

7] Diógenes - Enquanto tu, Crates, e tu, Antístenes, fizestes viagem com tais companheiros, juntamente comigo desceram Blépsias, o agiota do Pireu, o acarnense Lâmpis, comandante de mercenários, e Dâmis, um ricaço de Corinto. Dâmis morrera com uma dose de veneno ministrado por seu filho; Lâmpis matara-se por amor da hetera Mirtinha ${ }^{225}$; e

${ }^{224}$ o côvado equivale a cerca de $0,462 \mathrm{~cm}$; pelo que uma lança de 20 côvados teria um pouco mais de 9 metros...

${ }^{225}$ Muitas prostitutas tinham (ou usavam) nomes de forma diminutiva, geralmente em -ion, que em grego são do género neutro, e que, vertido segundo as regras, dão em port. formas de aparência masculinas. Aqui, a 
Blépsias, pobre dele!, tinha-se deixado mirrar de fome, segundo se dizia e era, aliás, manifesto pela sua aparência extremamente pálida e sua magreza excessiva. Ora eu, embora conhecedor do caso, perguntei-lhe de que forma é que ele tinha morrido; então, como Dâmis acusasse o filho, eu disse-lhe: "Não foi mal feito o que o teu filho te fez, porquanto, com uma fortuna à volta de mil talentos ${ }^{226}$, e ainda gozando as delicias da vida aos noventa anos, só davas quatro óbolos a um jovem de dezoito anos.»... E tu, ó acarnense (este também gemia e amaldiçoava a Mirtinha), porque deitas culpas a Eros, em vez de as deitares a ti próprio, tu, que nunca tremeste perante o inimigo, mas lutavas temerariamente à frente dos outros, e agora, meu valentáo, foste apanhado pelas lágrimas fingidas e pelos suspiros da primeira galdéria $^{227}$ que te apareceu... Finalmente Blépsias era o primeiro a recriminar-se pela sua grande estupidez, por guardar o seu dinheiro para herdeiros que não lhe eram nada, cuidando, o parvo, que havia de viver sempre. A mim, porém, todas essas lamentaçóes só me provocavam gozo, e não pouco... [8] Ora bem, eis-nos chegados à entrada; agora há que olhar e observar de longe os que vão chegando... Tchiiii! Como são tantos e tão variados, e todos chorosos, excepto aqui estes recém-nascidos que ainda não falam! Mas até os muito velhos se lamentam... Pois quê?! Será que ainda estão possuídos da magia da vida?... [9] Vou então interrogar este aqui muito velho: Porque choras, tu que morreste tão velho? Porque estás tão irritado, meu caro, apesar de teres chegado a velho? Porventura eras algum rei?

VELHO - De modo nenhum.

DiÓGENES - Algum sátrapa?228

VELHO - Também náo.

DIÓGENES - Acaso eras um ricaço, e agora te afliges por ter morrido e deixares tantas delícias?

personagem é designada por Mýrtion, que daria em port. Mírtio. Decidi verter em forma de diminutivo em -inha, talvez preferível (mas não superior!) a -inho (cf. versão do Prof. Costa Ramalho: Mirtinho).

${ }^{226} \mathrm{O}$ talento não era uma moeda, mas aquilo a que chamamos uma "unidade de conto» (cf. dez contos de reis): 1 talento $=60$ minas; 1 mina $=100 \mathrm{dracmas} ; 1 \mathrm{dracma}=6$ óbolos. Como se vê, trata-se de uma quantia elevadíssima.

${ }^{227}$ Adopto a interpretação do Prof. Costa Ramalho ("galderiazinha»)... com excepção do sufixo -inho, que não me pareceu necessário...

228 Os sátrapas eram os governadores de província do Império persa. 
VELHO - Também não, mas, pelo contrário, tinha chegado até cerca dos noventa anos, levava uma vida de privaçôes, vivendo da cana e da linha de pesca, extremamente pobre, sem filhos, e ainda por cima coxo e com falta de vista.

DIÓGENES - E ainda querias viver, mesmo nessa situação?

VELHO - Sim, porque a luz do dia me era agradável, e a morte era uma coisa horrenda e de fugir.

DIÓGENES - Ó velhote, estás a delirar e a comportas-te como um adolescente, ao falares do inevitável, e isto apesar de seres da idade do barqueiro 229 . Entáo que diríamos nós dos jovens, quando homens da tua idade são tấo apegados à vida e que, estes sim, deviam procurar a morte como remédio dos males da velhice?... Bem... afastemo-nos já daqui, não vá alguém, ao ver-nos cirandar junto da porta, desconfiar de que pretendemos evadir-nos ${ }^{230}$.

${ }^{229}$ Naturalmente, há aqui um exagero... mas muito expressivo.

${ }^{230}$ Esta ideia de "evasão" não deixa de ser, pelo menos, curiosa. 


\section{MENIPO E TIRÉSIAS ${ }^{231}$}

1] MENIPO - Ó Tirésias, se tu és realmente cego, eis o que já não é fácil de distinguir, pois todos nós temos olhos iguais, quer dizer, só as suas cavidades vazias, de modo que já não serias capaz de dizer quem é Fineu ${ }^{232}$ e quem é Linceu. Que tu eras um adivinho e que foste a única pessoa que se tornou nos dois sexos - homem e mulher — , sei-o por ter ouvido os poetas. Pois então, pelos deuses!, diz-me cá qual das duas vidas que experimentaste era mais agradável: quando eras homem, ou era melhor a vida de mulher?

TIRÉSIAS - Ó Menipo, era muito melhor a vida de mulher, pois é menos trabalhosa. De facto, as mulheres, além de dominarem os homens, não são obrigadas a ir à guerra, não estáo de sentinela nas muralhas, nem se deslocam à assembleia, nem são interrogadas em tribunal ${ }^{233}$.

2]MENIPO - Na verdade, ó Tirésias, nunca ouviste a Medeia de Eurípides, as coisas que essa personagem disse, lamentando a vida das mulheres, como elas eram infelizes e como estavam sujeitas às insuportáveis dores do parto? Mas... diz-me cá uma coisa que me foi sugerida pelos iambos da Medeia: No período em que tu, Tirésias, eras mulher, alguma vez deste à luz, ou permaneceste, nessa condição, a ser estéril e sem descendência?

TIRÉSIAS - Porque fazes essa pergunta, ó Menipo?

MENIPO - Não tem qualquer dificuldade, ó Tirésias. Mas responde lá, se puderes.

TIRÉSIAS - Não era estéril, não, mas nunca dei à luz.

MENIPO - Isso já me basta... Mas também gostava de saber se tinhas útero.

TIRÉSIAS - Claro que tinha.

${ }^{231}$ Tirésias é talvez o mais famoso adivinho da mitologia, mas a história da sua dupla e alternada condição de homem e mulher é menos conhecida. Naturalmente, Menipo não deixa de aproveitar o insólito da situação para fazer perguntas (im)pertinentes.

${ }^{232}$ Fineu, rei da Trácia, foi cegado por Posídon (lat. Neptuno); Linceu, um dos argonautas, era famoso pela sua visão... de lince...

${ }^{233}$ É curioso este conjunto de factores que tornam a vida das mulheres preferível à dos homens, os quais — dito de outra maneira — além de serem dominados pelas mulheres, são obrigadas a ir à guerra, estão de sentinela nas muralhas, deslocam-se à assembleia e são interrogadas em tribunal. 
MENIPO - Será que, a pouco e pouco, o útero desapareceu, os órgãos genitais se foram fechando e os seios se foram esvaziaram, e foi despontando o órgão viril e foi crescendo a barba, ou foi de repente que te transformaste de mulher em homem?

TIRÉSIAS - Não estou a ver o que queres dizer com essa pergunta. Parece que duvidas que as coisas se tenham passado assim.

MENIPO — Ó Tirésias, então não é caso para duvidar de tais fenómenos, em vez de aceitá-los, sem os examinar, como um basbaque, quer eles sejam possíveis, quer não?

3] TIRÉSIAS - Portanto, também não acreditas que tenham acontecido outros casos do mesmo género, quando ouves dizer que certas mulheres se transformaram em aves, em árvores ou em animais, como por exemplo Aédon ${ }^{234}$, Dafne ou a filha de Licáon?

MENIPO - Se por acaso um dia as encontrar, saberei aquilo que elas me disserem... Mas agora tu, meu caro, quando eras mulher, já tinhas o dom da adivinhação, como mais tarde, ou tornaste-te homem e adivinho ao mesmo tempo?

TIRÉSIAS - Estás a ver? Desconheces tudo a meu respeito, por exemplo, como resolvi uma disputa entre os deuses e, por isso, Hera me mutilou, mas Zeus consolou essa minha desgraça, dando-me o dom da adivinhação.

MENIPO - Ó Tirésias, entấo ainda és dado a mentiras? Bem... procedes assim à maneira dos adivinhos, pois é vosso costume não dizer nada de sensato.

${ }^{234}$ Aédon, figura feminina transformada em rouxinol. Dafne, ninfa dos bosques, por quem Apolo se apaixonou. Perseguida por este, invocou a mãe Terra, que a transformou num loureiro (daphne). Calisto, filha de Licáon, rei da Arcádia, foi amada por Zeus, mas, logo que deu à luz o pequeno Árcade, Hera, ciumenta como sempre, metamorfoseou-a em ursa. 


\section{9. Ájax e Agamémnon}

1] AgAmémnOn - Ó Ájax, se foste tu que, por teres enlouquecido, te mataste e até estiveste quase a matar-nos a nós todos, porque incriminas Ulisses, a ponto de, outro dia, nem sequer teres olhado para ele, quando veio consultar o oráculo, nem te dignaste dirigir a palavra a esse homem, que foi teu companheiro de armas e camarada, mas passaste por ele com modos arrogantes e a passos largos?

ÁJAX - É óbvio, Agamémnon, pois ele foi o causador da minha loucura, por ter sido o único a disputar-me a posse das armas.

AGAMÉMNON — Pretendias ficar sem adversário e apoderar-te das armas sem haver luta?

ÁJAX - Sim, é mesmo isso. De facto, essa panóplia ${ }^{235}$ vinha de família, por ter pertencido a um primo meu. Ora, vós outros, que éreis muito melhores que Ulisses, renunciastes à sua disputa e cedestes-me o prémio, ao passo que o filho de Laertes, que eu muitas vezes salvei quando ele corria o risco de ser despedaçado pelos Frígios ${ }^{236}$, achava-se melhor que eu e mais merecedor de possuir as armas.

2] AGAMÉmNON - Nesse caso, meu bravo, acusa antes Tétis, a qual, em vez de te entregar a herança das armas, por seres sua parente, as colocou à disposição de todos.

ÁJAX - De todos não, mas de Ulisses, o único que as reivindicou.

AGAMÉMNON - Ó Ájax, há que lhe perdoar, pois, sendo homem, se apaixonou pela glória, que é uma coisa muito agradável e pela qual todos nós suportávamos o perigo. Além disso, Ulisses também te venceu, e isso na presença dos Troianos, que serviram de juízes.

ÁJAX - Sei muito bem quem me condenou... mas não é lícito falar seja o que for a respeito dos deuses. No entanto, ó Agamémnon, não poderei deixar de odiar Ulisses, mesmo que Atena em pessoa me ordenasse o contrário.

${ }^{235}$ A panóplia era o armamento completo de um hoplita: escudo, elmo, couraça, coxote, espada e lança.

${ }^{236} \mathrm{O}$ termo Frígios acabou por ser sinónimo de Troianos. 
(Página deixada propositadamente em branco) 


\section{Minos e Sóstrato}

1] MinOS — Que aqui este salteador, o Sóstrato, seja lançado ao Piriflegetonte ${ }^{237}$; que aí o outro, o sacrílego, seja despedaçado pela Quimera ${ }^{238}$; que o tirano, ó Hermes, seja esticado ao lado de Ticio ${ }^{239}$ e que o seu fígado seja devorado pelos abutres. Quanto a vós, os bons, ide-vos daqui a toda a pressa para os Campos Elísios e habitai as ilhas dos bem-aventurados, como prémio das justas acçóes que praticastes durante a vossa vida.

SÓsTRATO — Ó Minos, escuta-me, a ver se te parece que eu tenho razão.

MinOS - Escutar-te outra vez... agora? Mas, ó Sóstrato, náo ficou provado que tu foste um facínora que assassinou tanta gente?

SÓSTRATO - Sim, ficou provado, mas vê lá se eu fui justamente castigado.

MinOS - Muito justamente, se é justo pagar pelo que se fez.

SÓsTrATO - Mesmo assim, ó Minos, responde-me, pois só vou fazer-te uma breve pergunta.

MiNOS - Fala, na condição de não te alongares, para que ainda possa julgar outros.

2] Sóstrato - Os actos eu cometi em vida, será que os cometi livremente, ou foram-me fiados pela Moira ${ }^{240}$ ?

MiNOS - Foram fiados pela Moira, é claro.

${ }^{237}$ O Piriflegetonte, um dos rios do Inferno, tem ondas de fogo e exala um forte cheiro a enxofre.

${ }^{238}$ Quimera, monstro que assolava a Lícia, foi morta por Belerofonte. Tal como a Esfinge, havia nascido da hidra de Lerna. A Quimera tinha a forma de uma cabra selvagem com cabeça de leão e cauda de serpente, e vomitava fogo.

239 Ticio era um gigante, que foi castigado por impiedade contra Latona: dois abutres roíam-lhe o fígado, que voltava a crescer. Compreende-se qual o duplo castigo a que Minos condena Sóstrato: ser esticado até atingir o comprimento do gigante, e ter o fígado devorado por abutres.

${ }^{240}$ As Moiras (ou Parcas), filhas de Zeus e de Témis (a Justiça), eram as divindades que presidiam ao destino dos humanos. Eram três: Cloto, Láquesis e Átropo. Láquesis determinava a parte de vida que cabia a cada pessoa e carregava a roca, que depunha nas máos de Cloto; Átropo, ao cortar o fio, punha termo aos dias de vida concedidos. Aqui, o singular, a Moira, refere-se a Cloto, como se vê a seguir. 
SÓsTRATO - Nesse caso, todos nós, quer os bons, quer os criminosos, agimos, ao que parece, por ordem dessa divindade, não é?

MINOS - Sim, por ordem de Cloto, a qual destinou a cada um, ao nascer, o que ele havia de fazer.

SÓSTRATO - Portanto, se alguém, obrigado por outro, matasse uma pessoa, sem ter possibilidade de resistir àquele que o forçara, como por exemplo um carrasco ou um mercenário (um obedecendo ao juiz, e o outro ao tirano), a quem é que tu acusarias da morte?

MINOS - Claro que ao juiz ou ao tirano, tal como não culparia uma espada, pois esta, como instrumento que é, serve apenas a vontade do primeiro, que age como causa inicial.

SÓsTRATO - Muito bem, Minos, tanto mais que vens reforçar o meu exemplo. Se alguém, enviado pelo seu senhor, vier trazer prata ou ouro a outra pessoa, a quem é que se deve agradecer? A quem é que se deve inscrever no rol dos benfeitores?

MINOS - Ao que enviou a coisa, ó Sóstrato, pois o portador foi apenas um criado.

3] Sóstrato - Portanto, estás a ver como procedes injustamente ao castigar-nos, a nós que fomos apenas servos executantes das ordens de Cloto, e ainda por cima enalteces estes aqui ${ }^{241}$, que agiram como simples executantes das boas acções de outros?! Na verdade, ninguém poderia dizer que era possível resistir a ordens dadas com força obrigatória.

MINOS - Ó Sóstrato, se examinasses minuciosamente, poderias ver muitas mais coisas que não estão de acordo com a razáo. Em todo o caso, com a tua pergunta, ganharás o seguinte (pois não pareces ser apenas um salteador, mas também um sofista): Ó Hermes, liberta-o, e que deixe de ser castigado... E tu, Sóstrato, vê lá não ensines os outros mortos a fazerem perguntas semelhantes ${ }^{242}$.

${ }^{241}$ Sóstrato refere-se concretamente àquelas personagens que, no início do diálogo, Minos havia mandado, em bloco, para os Campos Elísios.

${ }^{242}$ Este final é de uma força crítica arrasadora: não digas que vais daqui... 
O BIBLIÓMANO IGNORANTE 
(Página deixada propositadamente em branco) 


\section{ÀS MINHAS ANTIGAS MESTRAS PROFESSORAS MARIA MANUELA BARROSO DE ALBUQUERQUE MARIA DE LURDES FLOR DE OLIVEIRA}

.. Hoc primum sentio,
nisi in bonis amicitiam esse non posse.

(Cícero, De Amicitia, 5, 18) 
(Página deixada propositadamente em branco) 


\section{INTRODUÇÃO}

O Bibliómano Ignorante, escrito cerca de 170 d. C. ${ }^{243}$ (portanto na primeira fase da vida de Luciano em Atenas), tem por alvo uma personagem nitidamente real, não nomeada, mas facilmente identificável pelos leitores contemporâneos. Ficase com a nítida impressão de que se trata de algo mais do que uma vingança, pelo facto de um certo indivíduo ter recusado emprestar um livro a Luciano, que reage escrevendo contra ele uma violenta diatribe, em que acentua especialmente a ignorância da pessoa, mas sem deixar de aludir, como que de passagem, mas com efeito arrasador, aos aspectos morais do seu comportamento. Deviam ser velhos inimigos...

O título (que deve ser original) é claramente descritivo: K $\alpha \tau \dot{\alpha}$

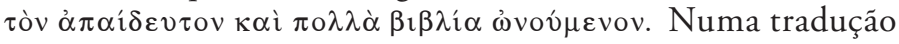
interpretativa, que dê conta das subtilezas do texto (e por isso conscientemente "alargada»), entendemos: Contra um certo $e$ determinado individuo muito ignorante, mas que tem a mania de comprar muitos livros. Numa tradução aparentemente mais chegada e mais concisa (mas com perda de «informação»), poderíamos dizer: Contra aquele ignorante que compra muitos livros. Perde-se em precisão o que se ganha em concisão. No comentário ao texto explica-se aquela interpretação. A nossa tradução, O Bibliómano Ignorante, agradou-nos pela sua concisão levada ao extremo, mas que parece conter os principais elementos do título original.

O tema da diatribe já está bem explícito no título, que, como se disse, é suficientemente descritivo. O desenvolvimento do tema mostra-nos um indivíduo sem cultura, mas que pretende fazer-se passar por intelectual, para o que se cerca dos «sintomas exteriores» de intelectualidade: frequenta as livrarias, onde adquire grandes quantidades de livros (ediçóes de luxo ou prestigiadas "primeiras ediçóes»), com que se pavoneia pelas ruas e praças de Atenas, rodeado de admiradores, que não perdem uma só ocasião de lhe gabar táo grandes méritos, a troco de jantaradas, onde também são obrigados a aplaudir... sem o que o dono da casa não passará à fase das bebidas.

Segundo as normas da composição literária, Luciano ilustra o seu ataque com exemplos similares, passados ou recentes, de

${ }^{243}$ V. nota ao $\$ 14$ da tradução. 
pessoas que pretenderam ou pretendem ser mais do que aquilo que são, sempre com resultado contrário às suas expectativas. Nesta obra, Luciano conta-nos uma dezena de histórias aplicáveis à personagem. O leitor moderno poderá ficar com a impressáo de um certo 'enchimento' artificial do tema, mas recordemos que se trata de um processo habitual. Sáo as seguintes essas histórias:

S6-Um individuo, amputado de ambos pés, usa botas do mais refinado luxo;

S 8-10 - O tarentino Evângelo concorre, nos Jogos Píticos, na disciplina de canto e música. Luxuosamente vestido e ostentando uma citara soberba, faz uma figura deplorável;

$\$ 12$ - História de Neanto, filho do tirano Pitaco, que adquiriu a lira de Orfeu, convencido de que esta faria dele um executante eximio. Resultado trágico;

S13-Um homem comprou por elevado preço a candeia de Epicteto, convicto de que, lendo todas as noites sob a mesma luz que o grande filósofo, ficaria igual ao seu primitivo dono;

S 14 - Uma outra pessoa comprou a preço de ouro (um talento) o cajado do filósofo cínico Proteu, que ostenta por toda a parte;

\ 15 - O tirano Dionisio, mau tragediógrafo, comprou a prancheta em que Ésquilo compunha as suas obras... mas nem assim passou a compor melhor;

\19-O filósofo cínico Demétrio, ao ver um individuo a ler desajeitadamente um passo das Bacantes de Euripides, arrebatou-lhe o livro e rasgou-o... a fim de poupar o grande trágico das tropelias infligidas por um leitor bárbaro;

\20-A suposta parecença do nosso homem com Pirro, rei do Epiro, e outros casos de semelhança com personalidades famosas: Pseudo-Alexandre, Pseudo-Filipe, Pseudo-Nero;

\21-História de Pirro, rei do Epiro, convencido de que era um autêntico sósia de Alexandre.

Mas Luciano não se contenta com atacar o snobismo ignorante do indivíduo, que até é seu patrício (sírio), e cujo princípio de vida ele bem conhece: o fulano conseguiu fazer-se herdeiro de um certo velho, após o que se transferiu para Atenas, onde a fortuna lhe permite levar uma vida não só luxuosa, mas também... luxuriosa. Este aspecto, que, no conjunto do tema, parece 
secundário, ganha, por isso mesmo, uma força subtilmente arrasadora. Ao longo da diatribe, surge, de vez em quando, uma 'farpa' dirigida ao comportamento imoral do sujeito ( $\$ \$$ 19, 22, 24, 25...). Mesmo no fecho da diatribe, Luciano volta a fazer uma leve mas clara referência à moralidade do indivíduo: "Por agora, é isto que tenho para te dizer francamente, apenas a respeito dos livros. Sobre as outras coisas nojentas e ignominiosas a que te dedicas, voltarás a ouvir-me, e muitas vezes."

Além do uso de histórias ilustrativas, Luciano cita vários provérbios (que apresentamos em versão literal, acompanhada do provérbio português mais aproximado.

S 4 - «Um macaco é [sempre] um macaco»

[O que o berço dá, a tumba o leva]

[Quem torto nasce, tarde ou nunca se endireita]

[Burro velho não aprende linguagem]

S 4 - "(Como) um burro, escutas uma lira, arrebitando as orelhas"

[Dar pérolas a porcos]

S 5 - "Que tem um cão a ver com um balneário?»

[Que tem a ver o cu com as calças»]

[Pra que queres tu botas, se tens as pernas tortas?]

$\int 23-$ «E mais fácil esconder cinco elefantes debaixo do sovaco, do que um debochado"

[Mais depressa se apanha um mentiroso que um coxo]

$\int 25$ - "O cão, uma vez ensinado a roer couro, nunca mais se desabitua"

[O hábito é uma segunda natureza]

$\int 28$ - "Estou tentando branquear um etiope»

[É malhar em ferro frio]

$\int 30$ - "É como o cão, que não come cevada nem deixa o cavalo comer" 
Como documento de uma época (Atenas na $2^{\mathrm{a}}$ metade do séc. II d. C.), O Bibliómano Ignorante informa-nos de um ambiente cultural em que a figura do intelectual mantinha bastante prestígio, o suficiente para que certas pessoas, mais ou menos autodidactas (como a nossa personagem), pretendessem entrar no círculo dessa gente importante.

Por outro lado, e em ligação com este aspecto, vemos que o comércio do livro estava em franco desenvolvimento: os comerciantes de livros tinham clientes para todo o tipo de ediçóes: as mais baratas, que satisfaziam perfeitamente os desejos dos menos afortunados, que apenas queriam ter acesso às obras, e as mais caras, que tanto podiam ser ediçóes recentes elaboradas com elevada técnica, como livros antigos (até mesmo autógrafos), mais ou menos danificados pelo tempo, mas que suscitavam a gula dos bibliófilos, a ponto de surgir a edição fraudulenta, em que os livros eram artificialmente envelhecidos. Luciano não deixa de fazer referência a este último aspecto, ao dizer que a personagem náo sabia distinguir entre as obras realmente antigas e as falsas antiguidades. Naturalmente, nem todos os amadores de livros antigos se deixavam enganar, mas o que é certo é que este negócio rendia bastante. 
O BIBLIÓMANO IGNORANTE 
(Página deixada propositadamente em branco) 


\section{O Bibliómano IgNoRANTE ${ }^{244}$}

1. Em boa verdade, o teu modo de proceder dá um resultado diametralmente oposto às tuas pretensôes. Sim: cuidas tu que serás considerado um grande senhor no mundo da cultura, só pelo facto de afanosamente adquirires grandes quantidades dos mais belos livros... Só que a coisa te dá para o torto e se torna, digamos, a prova provada da tua ignorância. Mais: tu nem ao menos adquires os livros mais belos, antes te fias naquelas pessoas que os louvam à toa, pelo que és não só uma presa fácil para os que dizem tais patranhas sobre os livros, mas também uma autêntica mina para os negociantes do ramo. Senão vejamos: com que base estás em condiçóes de distinguir entre os que são antigos e de grande valor, e os que são medíocres e artificialmente ${ }^{245}$ apodrecidos, a não ser que te fundamentes na maneira como estão carcomidos e mutilados e tragas à colação, para esse exame, os próprios vermes como teus conselheiros? Sim: no que toca a precisão e segurança nessa matéria, que outro julgamento haveria, e qual o seu valor?

2. Mas... vá lá... mesmo concedendo-te que tenhas essa capacidade de julgar [por exemplo] quais é que Calino ${ }^{246}$, em ediçóes de luxo, ou o célebre Ático, com toda a diligência, copiaram, que é que te aproveitaria, ó espantosa criatura, a sua propriedade, se tu nem entendes a beleza desses livros nem jamais poderás minimamente alguma vez deleitar-te com eles, mais do que um cego se deleitaria com a beleza de um seu rapazinho querido? Ora tu, é verdade, miras os teus livros com olhos esbugalhados e (por Zeus!) com um ar embevecido; chegas mesmo a ler alguns passos com bastante fluência, mantendo o olhar adiantado em relação à boca. Pois bem: para mim, isso náo basta, se tu não apreenderes as qualidades e os defeitos de cada um desses passos e não apanhares o seu sentido geral, qual a ligação das palavras, quais delas é que o

${ }^{244}$ Lit. $^{\text {te }}$ "Contra determinado indivíduo inculto que compra muitos livros». Ver nota ao texto, onde se encontram as observaçóes de natureza gramatical. Na tradução, reduzi e limitei as notas ao estritamente indispensável do ponto de vista da compreensão (alusóes históricas, mitológicas...).

${ }^{245}$ No texto grego, lit. ${ }^{\text {te }}$ "diferentemente», i. é, "por outras causas» (que não as causas naturais: humidade, ataque de traças...).

${ }^{246}$ Calino e Ático, editores de grande prestígio. V. nota 8 do texto grego. 
autor empregou com precisão e de acordo com as regras e quais [outras] são equívocas, bastardas ou mal formadas ${ }^{247}$.

3. O quê? Sustentas que, mesmo sem instrução, percebes dessas coisas tanto como nós? E donde é que te vem a ciência, a menos, talvez, que tenhas recebido das Musas um ramo de loureiro, tal como o famoso pastor? Na verdade - creio bem - tu nunca ouviste sequer falar do Hélicon, onde se diz que vivem essas divindades, nem seguiste, na tua juventude, os mesmos estudos que nós. Em ti, o próprio acto de mencionar as Musas já é algo de sacrílego. Sim, que elas não teriam hesitado em aparecer a um pastor ${ }^{248}$, homem duro, hirsuto e patenteando na pele o forte ardor do sol, ao passo que duma pessoa como tu (pela deusa do Líbano ${ }^{249}$, dispensa-me, por agora, de dizer tudo por claro!) tenho por certo que elas nunca se teriam dignado aproximar-se. Pelo contrário, fustigar-te-iam náo com ramos de loureiro, mas com mirto ${ }^{250}$, ou até com folhas de malva, e expulsar-te-iam de tais regióes, para que não conspurcasses o Olmio ${ }^{251}$ ou a Fonte do Cavalo [Hipocrene], em cujas águas só podem beber ou rebanhos sedentos ou bocas puras de pastores.

Verdadeiramente, por muito desavergonhado que sejas [e és], por muito destemido em coisas deste género, nunca te atreverias a dizer que recebeste instrução, ou que alguma vez na vida te preocupou o contacto íntimo com os livros, ou que fulano foi teu mestre, ou que frequentaste a escola de beltrano.

4. E no entanto, esperas agora corrigir tudo isso por um processo simples: adquirindo uma grande quantidade de livros. Nesta ordem de ideias, compra e colecciona todas as obras de Demóstenes que este orador redigiu por sua própria mão, ou, das de Tucídides, todas quantas subsistem, pertencentes ao espólio de Demóstenes e que este copiou oito vezes, ou, enfim, todos aqueles livros que Sula trouxe de Atenas para a Itália.

${ }^{247}$ Luciano, integrado no movimento aticista, dá grande valor à correcção linguística (ático clássico, claro).

248 Referência a Hesíodo, a quem as Musas apareceram no monte Hélicon. Todo o passo é alusivo a este poeta.

${ }^{249}$ A deusa do Líbano, ou Afrodite do Líbano, era venerada com ritos sexuais, que atingiam proporçóes de orgia, tal como o culto da deusa Cótis, a que Luciano se refere noutro passo.

${ }^{250} \mathrm{O}$ mirto e a malva tinham aplicaçôes medicinais, mas também mágicas. Nomeadamente, restituíam a razão aos tresloucados.

${ }^{251}$ Olmio, pequena ribeira da Beócia, afluente do Permesso. 
Mas que vantagem para a tua cultura retirarias daí, mesmo que ponhas os livros debaixo de ti e durmas sobre eles, ou passeies com eles colados a ti, a envolver-te todo? Lá diz o provérbio: "Um macaco é um macaco", ainda que tenha consigo objectos de ouro identificativos da sua origem. Também tu, de facto, trazes sempre um livro na mão e estás sempre a ler, embora não entendas nada do que lá está escrito, mas afinal, és tal qual um burro a arrebitar as orelhas ao ouvir uma lira.

É que... se o simples facto de possuir livros revelasse a cultura do seu possuidor, tal posse seria verdadeiramente preciosa e unicamente ao alcance de vós, os ricos, uma vez que vos seria possível comprá-la, como uma mercadoria, e, dessa forma, superiorizar-vos a nós, os pobres. Mas, nesse caso, quem poderia competir em cultura com os comerciantes e proprietários de livrarias, que possuem e vendem tão grande quantidade de livros? Ora, se queres uma demonstração completa, verificarás que esses tais não são muito superiores a ti em matéria de cultura, mas sim uns bárbaros no falar, tal como tu, e broncos de inteligência, como seria de esperar de pessoas que náo têm a noção do que é belo e do que é feio. E no entanto, tu possuis apenas uma meia dúzia ${ }^{252}$ de livros que lhes compraste, enquanto eles os têm entre mãos noite e dia.

5. Por conseguinte, que vantagem retiras da compra de livros... a menos que cuides que as próprias livrarias são cultas, pelo facto de conterem tantas obras notáveis de antigos escritores.

Ora responde-me, se fazes favor... ou melhor (já que isso te é impossível), baixa [afirmativamente] ou levanta [negativamente] a cabeça em resposta às minhas perguntas: se um homem que náo soubesse tocar flauta adquirisse as flautas de Timóteo, ou as de Isménias, que este comprou em Corinto por sete talentos ${ }^{253}$, acaso poderia ele, só por esse facto, tornar-se um bom flautista, ou não será que de nada lhe valeria a sua aquisição, visto não saber usar dela segundo as regras da arte? Bravo! Levantaste [negativamente] a cabeça. $\mathrm{Na}$ realidade, nem que ele tivesse adquirido a flauta de Mársias ou a de Olimpo se teria torna-

${ }^{252}$ Lit. $^{\text {te }}$ "dois ou três»... o que parece ser muito pouco para um coleccionador. Trata-se da chamada «numeração indeterminada». V. nota ao texto grego.

253 Sete talentos, uma soma elevadíssima: v. nota ao texto grego. 
do um bom flautista, a menos que tivesse aprendido. E que sucederia a quem adquirisse o arco de Héracles, sem ser um outro Filoctetes, capaz de esticá-lo e dispará-lo direito ao alvo? Que achas de uma tal pessoa? [Parece-te] que seria porventura capaz de cometer um feito digno de um arqueiro? Também a isto levantaste [negativamente] a cabeça. O mesmo se passa com uma pessoa que não conheça a arte de pilotar, ou com uma que nunca se exercitou no hipismo: aquela, se lhe dessem um belíssimo navio, magnificamente construído em todos os aspectos, no tocante quer a beleza, quer a segurança; esta, se adquirisse um cavalo medo [árabe] ou um centáuride ou um copátias: quer uma, quer outra mostrariam - estou certo - não saber servir-se da respectiva aquisição. Fazes que sim baixando a cabeça? Então convence-te também do seguinte e faz também que sim com a cabeça: se uma pessoa inculta, como tu, andasse sempre a comprar grandes porçôes de livros, não suscitaria contra si [veementes] censuras, devido à sua incultura? Porque hesitas em também fazer que sim com a cabeça? Realmente, essa seria uma prova evidente, e qualquer pessoa que assim o visse, logo citaria o conhecido e bem apropriado provérbio: "Que term um cão a ver com um balneário?".

6. Ainda não há muito tempo, houve na Ásia um certo indivíduo, muito rico, a quem, por sua infelicidade, tiveram de amputar ambos os pés, completamente gangrenados, devido creio eu - ao frio, pois sucedera ter de viajar através da neve. Ficou, é claro, numa situação deplorável. Então, como remédio para a desgraça, mandou fazer uns pés de madeira, que aplicava para caminhar, e mesmo assim apoiando-se nos criados. No entanto, passou a fazer uma coisa ridícula: costumava comprar as mais belas botas, sempre feitas de encomenda ${ }^{254}$, nas quais punha os maiores cuidados, de forma que esses seus pés de pau andassem sempre adornados com o mais belo calçado. Ora bem: não é precisamente assim que tu procedes, com essa tua inteligência "coxa»" 255 "de pau de figueira», ao comprares [como que] "coturnos» de oiro, com os quais até mesmo uma pessoa escorreita de pés dificilmente seria capaz de caminhar?

${ }^{254}$ Lit. $^{\text {te }}$ "talhadas de novo", i. é, "feitas de encomenda» ou, por extensão, "da última moda».

255 «inteligência 'coxa' e 'de pau de figueira'»: estilo figurado, tirado da imagem do amputado de pés, que tinha pés de pau. 
7. Mas, já que, entre outros livros, compraste, em diversas ocasiōes $^{256}$, as obras de Homero, pede a alguém que tome e te leia o canto II da Ilíada desse poeta, sem, no entanto, examinar outros passos (os quais, na verdade, não se aplicam à tua pessoa), mas apenas aquele em que ele, Homero, descreve um certo indivíduo a discursar, completamente ridículo, fisicamente disforme e desfigurado. Pois bem: se esse tal sujeito, Tersites $^{257}$, recebesse a armadura de Aquiles, cuidas tu que ficaria automaticamente belo e forte, que atravessaria o rio e o tingiria do sangue dos Frígios, que mataria Heitor e, antes dele, Licáon e Asteropeu, ele que não tinha força nem sequer para levar nos ombros a lança de madeira de freixo? Não poderias afirmar tal coisa. Pelo contrário, seria motivo de troça, assim a coxear debaixo do escudo e a cair de bruços vergado ao peso deste, deixando ver por sob o elmo, sempre que levantasse a cabeça, aqueles seus olhos esbugalhados, tentando segurar a couraça com a bossa das costas, arrastando as polainas... enfim, envergonhando quer o fabricante dessas armas, quer o seu possuidor. Então não vês que o mesmo se passa contigo, quando tens na mão um livro realmente muito belo, com uma capa cor de púrpura, com um botáo de fecho em ouro... mas que tu lês de forma bárbara, conspurcando-o e adulterando-o, tornando-te motivo de riso por parte das pessoas cultas, ainda que aplaudido pelos que contigo convivem, os quais também, na sua maior parte, se viram uns para os outros e riem?

8. Vou contar-te um episódio passado em Delfos. Certo tarentino, de nome Evângelo e pessoa nada obscura em Tarento, pretendeu uma vez alcançar uma vitória nos Jogos Píticos. Em relação a competiçóes atléticas, imediatamente se apercebeu de que isso lhe estava vedado, por não ser naturalmente dotado quer em força, quer em velocidade; mas, na disciplina de cítara e canto, deixou-se convencer por

${ }^{256}$ Entenda-se que o nosso homem possuía várias e variadas ediçōes de Homero (das muitas que circulavam), ou então (e também) cantos separados, pois náo era praticamente possível incluir todo o poema (neste caso a Ilíada) num único rolo. Aliás, Luciano fala aqui, expressamente, do canto II, que devia estar separadamente num rolo.

257 Tersites era o grego mais feio, mais cobarde e mais insolente de todos os que estiveram na guerra de Tróia (v. Ilíada, II, 212). Luciano refere-se-lhe noutras obras, p. ex., História Verídica, II, 20, Diálogos dos Mortos, 25, etc. 
pessoas execráveis da sua roda, que o gabavam e aplaudiam sempre que ele dedilhava a mais pequena nota de abertura, de que facilmente venceria. Chegou, pois, a Delfos, num aparato em tudo espampanante, nomeadamente com uma veste bordada a oiro, que mandara fazer expressamente, e uma coroa de louro belíssima e de oiro, a ponto de as bagas de loureiro serem esmeraldas do tamanho das bagas. Quanto à cítara, era um instrumento soberbo, tanto em beleza como em sumptuosidade, toda de oiro puro, toda ornamentada de jóias cravejadas e de variadas pedras preciosas, por entre as quais [se representavam] as Musas, Apolo e Orfeu... enfim, uma coisa maravilhosa de se ver.

9. Quando, finalmente, chegou o dia do certame, apresentaram-se três concorrentes, calhando a Evângelo cantar em segundo lugar. Assim, a seguir a Téspis de Tebas, que não tinha actuado nada mal, entra ele, todo rebrilhante de oiro, esmeraldas, berilos e jacintos ${ }^{258}$ [safiras]. Até a púrpura da sua veste lhe assentava magnificamente, deixando-se vislumbrar por entre o oiro. Com todo este aparato, conseguira antecipadamente deslumbrar o teatro em peso e encher os espectadores duma expectativa de maravilhas; mas quando, finalmente, chegou mesmo a sua vez de cantar e tocar cítara, começa por executar um prelúdio desafinado e fora do ritmo; a seguir, rebenta com três cordas de uma assentada, ao atacar a cítara com mais força do que convinha; depois, começa a cantar, mas com uma voz desengraçada e fraca, a ponto de suscitar risadas por parte dos espectadores e de os juízes, indignados com a sua ousadia, lhe mandarem dar umas chibatadas e o expulsarem do teatro. Assistiu-se então a uma cena ridícula, com o precioso Evângelo a chorar, arrastado pelos guardas [mastigóforos ${ }^{259}$ ] através da cena, com as pernas ensanguentadas das chibatadas e apanhando do chão as jóias da cítara, que também se tinham espalhado, pois o instrumento havia sido igualmente "chicoteado» ${ }^{\otimes}$.

258 «jacinto» era, na acepção mais comum, a conhecida planta, mas também uma pedra preciosa do tipo da safira.

259 Os mastigóforos, "portadores de chicote» eram os guardas encarregados da segurança e da tranquilidade pública, especialmente em espectáculos que juntavam muita gente. 
10. Passado um breve intervalo depois desta actuação, foi a vez de entrar um tal Eumelo da Élide, que trazia uma velha cítara com cavilhas de madeira e uma veste que mal valeria dez dracmas, incluindo a coroa. Mas foi justamente este que, após uma excelente exibiçãa de canto e uma execução de cítara segundo as regras da arte, levou a palma e foi proclamado vencedor, acabando por meter a ridículo Evângelo, que tinha feito um vão espavento com a cítara e com todas aquelas jóias. Até se conta que Eumelo lhe disse: "Evângelo, tu cinges o louro de oiro, pois és rico, ao passo que eu, que sou pobre, cinjo o louro délfico. No entanto, com o teu equipamento, só ganhaste uma coisa: vais daqui sem que ninguém se compadeça do teu falhanço, e ainda por cima odiado por essa tua insolência grosseira». O exemplo deste Evângelo assenta-te lindamente, apenas com a diferença de que tu não te preocupas, por pouco que seja, com a risota dos espectadores.

11. Também não viria fora de propósito contar-te uma história passada há muito tempo em Lesbos. Diz-se que, quando as mulheres da Trácia despedaçaram Orfeu, a sua cabeça, juntamente com a lira, caiu ao rio Hebro e foram ambas dar ao "Golfo Negro» [Mar Egeu]. Enquanto a cabeça, flutuando sobre a lira, cantava um treno por Orfeu - é o que se conta -, a lira acompanhava-a por si mesma, ao simples sopro dos ventos nas cordas, e assim, ao som da música, aportaram a Lesbos, onde os habitantes recolheram a cabeça de Orfeu e lhe deram sepultura, no local onde está agora o templo de Dioniso. Quanto à lira, foi oferecida ao santuário de Apolo, onde se conservou durante muito tempo.

12. Passado algum tempo, Neanto, filho do tirano Pítaco, tendo ouvido falar dessa lira, de como ela fascinava feras, plantas e pedras, e de como, depois da tragédia sucedida a Orfeu, continuava a tocar sem que ninguém a dedilhasse, sentiu um vivo desejo de a possuir, pelo que, a poder de muito dinheiro, subornou o sacerdote, convencendo-o a pôr no lugar da lira uma outra igual e lhe entregar a de Orfeu. Mas, uma vez na sua posse, não achava seguro utilizá-la em pleno dia na cidade, e então, uma noite, com a lira escondida no seio, saiu sozinho para os arredores, pegou na lira e, como jovem inábil e inexperiente que era, começou a atacar e a atormentar as cordas, esperando que a lira produzisse árias divinas, pelas 
quais toda a gente se sentiria fascinada e encantada, e que, enfim, ficaria cumulado de felicidade por ter herdado o génio musical de Orfeu. Eis senáo quando, uns cáes, dos muitos que havia por aquelas paragens, acorreram ao som e despedaçaram o homem, de modo que, pelo menos neste ponto, teve a mesma sorte que Orfeu, com a diferença de que só conseguiu atrair cães sobre si, donde se conclui com toda a clareza que não era a lira [por si] que encantava, mas sim a arte e o canto que, em grau excelente e ímpar, Orfeu possuía por herança materna. A lira, essa, era um objecto vulgar, náo melhor que qualquer outro instrumento de corda.

13. Mas para que estou eu a falar-te de Orfeu e de Neanto, quando, no nosso próprio tempo, existiu um indivíduo, e ainda vive - cuido eu -, que comprou por três mil dracmas a candeia, que era [simplesmente] de barro ${ }^{260}$, do filósofo estóico Epicteto? De facto - suponho eu -, o fulano esperava que, se fizesse todas as noites as suas leituras à luz dessa candeia, adquiriria logo a seguir, enquanto dormia ${ }^{261}$, a sabedoria de Epicteto e ficaria igual a esse admirável ancião.

14. Ainda há coisa de pouco tempo, um outro fulano comprou por um talento o cajado do filósofo cínico Proteu ${ }^{262}$, que este atirou fora quando se lançou na fogueira. Agora, conserva essa preciosa relíquia e ostenta-a, tal como os Tegeatas ostentam a pele do javali calidónio ${ }^{263}$, ou os Tebanos os ossos de Gérion,

${ }^{260}$ A expressão "que era de barro» tem, no texto grego, uma força especial, significando, implicitamente, que não era de um material mais caro, mas uma simples candeia de barro.

261 «enquanto dormia», ou «em sonho». Esta pode ser uma das primeiras referências ao aprendizado hipnótico...

262 "Proteu» (não confundir com o deus marinho) era a alcunha do filósofo Peregrino (100-165 d. C.), que se suicidou pelo fogo, durante os Jogos Olímpicos. Luciano escreveu sobre esta personagem o livro Perì tês Peregrínou teleutês (A Morte de Peregrino). Por aqui se vê que $O$ Bibliómano Ignorante foi escrito depois de 165 d. C., mas não necessariamente logo a seguir à morte do filósofo. A compra do seu cajado aconteceu, literalmente, "ontem ou anteontem», que é uma expressão de tempo indeterminado = «há coisa de pouco tempo». Por isso admitimos que a obra foi escrita (em números 'redondos') por volta de $170 \mathrm{~d}$. C.

${ }^{263}$ Este terrível javali, que Ártemis enviou, por vingança, para devastar as terras da cidade etólia de Cálidon, foi morto por Meléagro. Gérion, o gigante de três cabeças, está envolvido num dos «trabalhos de Hércules». 
ou os Menfitas as madeixas de Ísis. O dono deste maravilhoso objecto até te ultrapassou em ignorância e descaramento. Estás a ver como ele está doido varrido, mesmo a precisar de umas boas cajadadas na cabeça.

15. Também se conta que [o tirano] Dionísio ${ }^{264}$ compunha tragédias num estilo muito vulgar e ridículo, a ponto de Filóxeno ter ido muitas vezes parar ao cárcere por causa delas, pois não era capaz de conter o riso. Entáo, apercebendo-se de que era motivo de mofa, adquiriu a prancheta de Ésquilo, em que este costumava escrever, cuidando que ficaria inspirado e possuído [de veia poética], por virtude da prancheta. Apesar disso, porém, o que nela escrevia era ainda mais ridículo, como por exemplo:

\section{Dóride morreu, a mulher de Dionisio}

ou ainda:

Ai de mim, uma mulher prestável perdi!

Era isto, na verdade, o que a prancheta lhe inspirava;

ou ainda:

Realmente, os tolos dos mortais iludem-se a si próprios.

Pelo menos este verso, poderia Dioniso, com toda a propriedade, aplicá-lo à tua pessoa, e só por ele devia aquela prancheta ser revestida a ouro.

16. Mas que esperança póes tu nos livros, para estares sempre a desenrolá-los, a colá-los, a apará-los, a untá-los com [óleo de] açafrão e [óleo de] cedro, a encapá-los com pele e a colocar-lhes botóes de fecho, como se fosses tirar deles algum proveito? Será que, à força de comprares livros, és agora muito melhor, como tu, por um lado, proclamas - Mas estás mais calado que um peixe -, enquanto, por outro lado, vives de uma forma que nem é decente dizer e, pela tua conduta infame, suscitas por parte das pessoas - como sói dizer-se - «um ódio

${ }^{264}$ Dionísio, tirano de Siracusa (431-367 a. C.), reinou a partir de 405 a. C. 
figadal»? Concluindo, se os livros produzissem pessoas dessa tua laia, seria caso para fugir deles a sete pés e para o mais longe possível.

17. Ora, havendo duas coisas que se podem obter do contacto com os antigos - capacidade de expressão e cumprimento dos deveres, por imitação dos melhores e rejeição dos piores -, quando uma pessoa nấo se revela capaz de aproveitar deles nem uma coisa nem outra, não é verdade que está antes a comprar ninhos para os ratos, habitação para as traças e pancadaria para os criados, a pretexto de estes serem desmazelados?

18. Mais ainda: não seria uma vergonha [para ti] que alguém, vendo-te com um livro na mão (e tu tens sempre, mas mesmo sempre, algum contigo), te perguntasse de que orador, historiador ou poeta era o livro? Então tu, pela leitura do título, responderias facilmente à pergunta; mas em seguida (pois estas coisas, na convivência, costumam dar em conversa prolongada), quando o outro louvasse ou criticasse algum aspecto do conteúdo, tu ficarias embaraçado, sem nada para dizer. Não desejarias tu, nesse momento, que a terra se abrisse debaixo dos teus pés, qual Belerofonte ${ }^{265}$, que levava consigo um escrito contra si próprio?

19. O filósofo cínico Demétrio ${ }^{266}$, ao ver, em Corinto, um fulano inculto a ler um belíssimo livro (cuido que as Bacantes de Eurípides, naquele passo em que o mensageiro narra o infortúnio de Penteu ${ }^{267}$ e o acto de Agave), arrebatou-lhe o livro e, rasgando-o, disse: «É melhor para Penteu ser despedaçado de uma vez por mim, do que muitas vezes por ti.»

Ora, pergunto constantemente a mim mesmo, sem nunca, até hoje, ter sido capaz de descobrir, por que motivo te dedicas com tanto zelo a essa actividade de comprar livros. Ninguém, de entre aqueles que te conhecem, mesmo que muito pouco,

${ }^{265} \mathrm{Na}$ sequência de uma história longa de contar, Belerofonte, filho do deus Posídon, foi encarregado pelo rei de Tirinto de levar a Ióbates, rei da Lícia, uma carta, na qual se pedia que matasse o portador... o que náo aconteceu...

266 Este Demétrio (nome de muitas personagens ilustres) viveu no tempo de Calígula, Nero e Vespasiano.

267 Penteu, rei de Tebas, pretendia acabar com os rituais orgiásticos celebrados pelas mulheres de Tebas em honra de Baco (Dioniso). Foi despedaçado por elas, entre as quais teve parte activa a sua própria máe, Agave. 
julgaria que fosse por razóes de utilidade ou de necessidade, nada mais [nada menos] do que se um calvo comprasse pentes, ou um cego um espelho, ou um surdo um tocador de flauta, ou um eunuco uma concubina, ou um homem do campo um remo, ou um piloto um arado. Náo se tratará antes de um caso de ostentação de riqueza, em que pretendes mostrar a toda a gente que esbanjas a tua enorme fortuna com coisas que náo te são absolutamente nada úteis? Todavia, tanto quanto sei na minha qualidade de sírio, se não te tivesses apressado a fazer-te inscrever fraudulentamente no testamento de um certo velho, estarias agora a morrer de fome e porias à venda os teus livros.

20. Só resta, portanto, uma explicação: persuadido pelos bajuladores de que és não só belo e amável, mas também um sábio, um orador e um prosador como náo existe outro, compras livros como que para justificar os seus elogios. Diz-se até que tu, depois do jantar, costumas fazer-lhes um discurso, e eles, à maneira de rấs em seco, ficam a grasnar de sede, e não bebem enquanto não rebentarem em aplausos.

De facto, não sei lá como, és facílimo de arrastar pelo nariz, acreditas em tudo o que te dizem, como uma vez, em que te deixaste convencer de que eras a cara chapada de um certo príncipe, como sucedeu com o Pseudo-Alexandre, ou com o Pseudo-Filipe, que era pisoeiro, ou, no tempo dos nossos avós, com o Pseudo-Nero, ou, enfim, com qualquer outro de entre os que têm sido apelidados de Pseudo-[Qualquer Coisa].

21. Mas que grande admiração que isso aconteça contigo, pessoa estúpida e ignorante, que te mostras em público com ar enfatuado, imitando o andar, a pose e a maneira de olhar daquela pessoa com cuja semelhança te comprazes, quando - segundo se diz - o próprio Pirro, rei do Epiro e homem, de resto, maravilhoso, foi, num caso idêntico, de tal modo estragado pelos bajuladores, que acreditava ser parecido com o famoso Alexandre. E no entanto - para usar uma linguagem musical -, a diferença era de duas oitavas. Sim, que eu já vi uma imagem de Pirro. Mesmo assim, estava convencido de que era a cara chapada de Alexandre... Mas, com esta história, estou a cometer uma ofensa a Pirro, ao comparar-te a ele neste aspecto. Mas o que vem a seguir, isso sim, assenta-te às mil maravilhas. Estando Pirro neste estado, acreditando no que se dizia a seu respeito, não havia ninguém que náo assumisse 
a mesma opinião e não concordasse com ele... até que uma velha estrangeira, em Larissa, lhe disse a verdade, acabando-lhe assim com a tolice. De facto, Pirro, tendo-lhe mostrado a imagem de Filipe, de Perdicas, de Alexandre, de Cassandro e de outros reis, perguntou-lhe com qual deles o achava parecido, absolutamente convencido de que a velha apontaria para a imagem de Alexandre. Ela, porém, depois de pensar longamente, respondeu: "Com Batraquião, o cozinheiro». Realmente, havia em Larissa um cozinheiro chamado Batraquiáo, que era muito parecido com Pirro.

22. Quanto a ti, não seria capaz de dizer com qual te pareces de entre os depravados que se juntam aos actores de pantomimas, mas o que eu sei de ciência certa é que, aos olhos de toda a gente, pareces atacado de uma loucura galopante por essa parecença. Não é, pois, de admirar que tu, um "pintor» assim táo pouco convincente, pretendas assemelhar-te a pessoas cultas e acredites em quem te gaba tais qualidades.

Mas para que estou eu para aqui a divagar? Na realidade, é claro o motivo do teu interesse pelos livros; eu é que, por lentidão de inteligência, não o tinha visto mais cedo. De facto, meteste na cabeça um plano engenhoso (pelo menos é o que tu cuidas) e póes nele esperanças nada pequenas: se o rei, que é um homem erudito e dá muito valor à cultura, soubesse do teu caso, se ele ouvisse falar disso a teu respeito, isto é, que compras e coleccionas grandes quantidades de livros, brevemente - esperas tu - conseguirias tudo dele.

23. Mas... julgas tu, meu debochado, que ele está tão encharcado de mandrágora ${ }^{268}$, que dê ouvidos a essa fama, sem, por outro lado, saber de outras coisas [a teu respeito], como sejam o teu modo de vida durante o dia, mas também as tuas bebedeiras, o estilo das tuas noitadas e com que gente, e de que qualidade, tu dormes? Não sabes como são numerosos os ouvidos e os olhos de um rei? Ora, os teus actos são tão manifestos, que até os cegos e os surdos os conhecem. $\mathrm{Na}$ verdade, bastaria abrires a boca, bastaria despires-te para o banho [público]... ou por outra, não te dispas, por favor, mas dispam-se apenas os teus criados: Que tal? Náo ficariam imediatamente patentes os teus inconfessáveis segredos nocturnos?

${ }^{268}$ A mandrágora era usada como estupefaciente e soporífero. 
Mas diz-me cá mais uma coisa: se Basso, esse vosso grande intelectual, ou Bátalo, o tocador de flauta, ou o debochado Hemíteon de Síbaris, que compôs para vosso uso um espantoso tratado onde se ensina a amaciar a pele, a depilar, a 'suportar' e 'praticar' coisas abomináveis - se algum deles, agora mesmo, se pusesse para aí a deambular envolvido numa pele de leão e com uma moca na mão, que é que achas que pareceriam aos olhos das pessoas? Héracles, porventura? Não, a menos que tivessem umas remelas do tamanho de panelas. Realmente, há mil e uma coisas que desmentem essa aparência exterior: o modo de andar e de olhar, a voz, o pescoço pendurado para a frente, o alvaiade e o rouge de algas com que vos embelezais... numa palavra - e como diz o provérbio - "é mais fácil esconder cinco elefantes debaixo do sovaco, do que um debochado". Ora, se uma pele de leáo náo disfarçaria uma tal pessoa, cuidas tu que passarias despercebido [na tua ignorância], assim escondido por detrás de um livro? Mas tal não é possível, pois todas as outras vossas características te trairão e porão a descoberto.

24. Mas tu pareces ignorar por completo que não deves procurar alcançar essas tuas boas esperanças junto dos comerciantes de livros, mas sim tomá-las de ti próprio e do teu modo de vida quotidiano. Cuidas tu que editores como Ático ou Calino serão teus advogados públicos ou tuas testemunhas? Pelo contrário, haverá pessoas impiedosas que te esmagarão, se os deuses quiserem, e te reduzirão à extrema pobreza. Devias, desde já, ganhar juízo e vender esses livros a alguma pessoa culta, e, juntamente com eles, essa tua casa recém-construída, e [com esse dinheiro] pagar aos mercadores de escravos pelo menos uma parte do muito que lhes deves.

25. Sim, é isso mesmo, tens uma terrível paixão por estas duas coisas: a aquisição de ediçóes de luxo e a compra de rapazolas crescidotes e já robustos, actividade que ocupa muito do teu zelo e da tua procura. Todavia, se ficares pobre, é-te impossível atender a ambas as actividades. Portanto, considera um conselho como uma coisa preciosa. De facto, é minha ideia que deves pôr de lado aquela que não te fica nada bem, e cultivar o teu outro vício, i. é, adquirir servidores, de forma que, à falta de pessoal de tua casa, não tenhas de mandar vir pessoas livres, as quais, no caso de não serem bem pagas, sairão dali e divulgaráo impunemente aquilo que vós fazeis depois 
de beber, como [aconteceu] outro dia, em que um debochado, após sair de tua casa, andava por aí a contar as coisas mais vergonhosas a teu respeito, mostrando até umas marcas de mordidelas. Até podia mencionar-te pessoas presentes na altura, que testemunhariam como eu próprio fiquei indignado com o fulano e por pouco que não lhe dei umas bordoadas, revoltado como estava por consideração pela tua pessoa, e ainda mais quando ele invocou como testemunha outro tipo da mesma laia, e outro ainda, os quais contavam exactamente a mesma coisa. Portanto, meu caro, continua a administrar bem o teu dinheiro, a poupá-lo, para poderes, em tua casa e na maior segurança, praticar e "suportar» tais actos. Sim, ao ponto a que a coisa chegou, quem poderia persuadir-te a deixar de proceder desse modo? Tal qual o cáo, que, uma vez ensinado a roer couro, não será capaz de se deixar disso.

26. Quanto ao meu outro conselho, é fácil [de seguir]: de hoje em diante, não compres mais livros. Já és suficientemente culto, já tens sabedoria que baste, pouco falta para que tenhas na ponta da língua todas as obras antigas. Conheces toda a História, toda a arte literária com as suas virtudes e os seus defeitos, o uso do vocabulário ático... Graças à enorme quantidade de livros [que possuis], tornaste-te uma criatura sapientíssima, um expoente em matéria de cultura. Bem... nada obsta a que eu gaste assim o meu tempo contigo, já que aprecias ser enganado.

27. Gostaria, porém, de te perguntar uma coisa: possuindo tu tantos livros, qual deles preferes ler? Os de Platão? Os de Antístenes? Os de Arquíloco? Os de Hipónax? Ou será que menosprezas esses e preferes ter à mão os oradores? Diz-me cá: costumas ler o discurso de Ésquines Contra Timarco? É possível que conheças todas essas obras e entendas todos os seus pormenores... Mas já te embrenhaste bem em Aristófanes e em Êupolis? Já leste integralmente os Purificadores ${ }^{269}$ ? E então não te tocou [pessoalmente] nada do que aí está contido? Não coraste ao reconhecer [em ti] esses traços? Mas aquilo que mais espantaria as pessoas é com que estado de alma tocas nos

${ }^{269}$ Comédia de Êupolis, uma sátira contra os devotos da deusa trácia Cótis ou Cotito, também venerada em Corinto. O seu culto envolvia ritos orgiásticos. 
livros, com que mãos os desenrolas. E quando é que costumas ler? Durante o dia? Eis uma coisa que nunca ninguém te viu fazer. Durante a noite? Mas... já depois de te ocupares ${ }^{270} \mathrm{com}$ esses tais fulanos?!... Ou será ao lusco-fusco?!

28. De qualquer forma, [por Cótis!271], nunca mais te atrevas a uma coisa dessas: deixa lá os livros e trata apenas das tuas coisas... E mesmo dessas náo devias tratar, mas respeitar a Fedra de Eurípides, quando ela, irritada contra as mulheres, diz:

\section{Não temem nem as trevas suas cúmplices} nem que os tectos das casas soltem vozes.

Se, porém, estás firmemente decidido a persistir em semelhante vício ${ }^{272}$, vamos!, continua a comprar livros, sim, mas aferrolha-os em tua casa e goza a glória ${ }^{273}$ de os possuíres. Para ti, é quanto basta. Mas nunca lhes toques, nunca os leias, nunca submetas à tua língua as prosas ou os poemas de autores antigos, que não te fizeram mal nenhum.

Bem sei que tenho estado para aqui a divagar inutilmente sobre o mesmo assunto. Como diz o provérbio, "estou tentando branquear um etiope». Efectivamente, tu continuarás a

270 ... ocupares [tensamente e 'tesamente']: o verbo tem sentido priápico.

${ }^{271}$ Cótis: v. nota supra. A lição prós Kótyos é conjectural: v. «Apêndice».

$272 \mathrm{O}$ texto diz, literalmente, "doença», considerando-se o vício como uma doença do espírito. O grego náo tem uma palavra para designar $\boldsymbol{u m}$ mau hábito. Não serviria, pelo menos neste caso, o termo ع́ $\theta$ os, que Aristt.

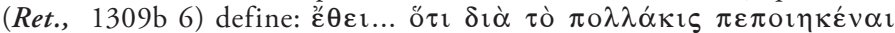

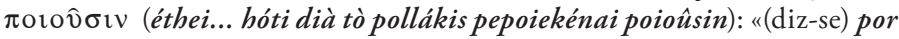
hábito... porque se faz por se ter feito muitas vezes». Assim, a palavra não tem a carga negativa do vício ou mau hábito. Também seriam inadequados

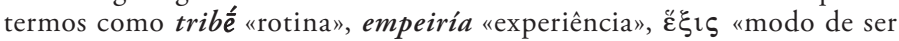
habitual», "temperamento"... E poderíamos experimentar outras palavras: eláttōma "imperfeição", "defeito", tò kakón "mal (em geral)», "malefício", kakía, mokhtēría, ponēría "maldade», akolasía, asélgeia «libertinagem». De todas elas, parece que nósos "doença», mas com a carga (embora contextual) de «doença mental».

273 dóxa significa propr. ${ }^{\text {te }}$ "opinião», "reputação", "fama», mas o sentido de "glória» já era corrente na koinê (v. numerosos passos do Novo Testamento). Mesmo que Luciano só pensasse em «reputação», muitos leitores não deixariam de sentir a acepção corrente, de resto, muito próxima. V. o mesmo termo no $\$$ seguinte, que traduzi por «fama». 
comprá-los e a não tirar deles qualquer proveito, continuarás a ser motivo de troça das pessoas cultas, às quais basta tirar benefício, não da beleza das ediçôes nem do seu luxo, mas sim da forma literária e do pensamento dos autores.

29. Mas tu cuidas remediar e encobrir a tua ignorância com essa [simples] fama ${ }^{274}$, cuidas espantar as pessoas com a quantidade dos teus livros, sem te aperceberes de que, [p. ex.] os médicos mais incompetentes procedem como tu: mandam fazer estojos de marfim, ventosas de prata e bisturis cravejados de ouro; quando, porém, chega o momento de se servirem destes instrumentos, nem sequer sabem manejá-los como deve ser. Então, chega ao local um qualquer dos que aprenderam [a arte da medicina] e, com uma lanceta bem afiada, aliás coberta de ferrugem ${ }^{275}$, e já está: livra o paciente do seu sofrimento.

Mas deixa-me comparar o teu caso com um ainda mais ridículo: observa esses barbeiros que há por aí e verás que, entre eles, os mestres usam apenas uma navalha de barbear, uma tesoura e um espelho vulgar, ao passo que os incompetentes e amadores, embora fazendo espavento de grandes quantidades de tesouras e de enormes espelhos, não conseguiráo, com tudo isso, esconder a sua ignorância. Mas ainda o maior ridículo por que passam é que muitos vão cortar o cabelo nas barbearias dos vizinhos destes, mas depois vêm aos espelhos dos outros compor o penteado.

30. Assim, também tu poderias facultar os teus livros a quem deles tivesse necessidade, embora tu, propriamente, não sejas capaz de te servir deles. Todavia, tu nunca emprestaste um [único] livro fosse a quem fosse, mas fazes como o cáo que está na manjedoura, o qual não come cevada, mas também não deixa comer o cavalo, que poderia fazê-lo.

Por agora, é isto que tenho para te dizer, com toda a franqueza, a respeito somente dos livros. No que respeita a outras actividades nojentas e ignominiosas a que te dedicas, voltarás a ouvir-me... e muitas vezes.

274 «fama»: v. $\$$ precedente.

275 É claro que Luciano e os seus contemporâneos desconheciam os agentes infecciosos... mas isso só foi conhecido ... antes de ontem! 
ALEXANDRE OU O FALSO PROFETA 
(Página deixada propositadamente em branco) 


\section{INTRODUÇÃo}

No tempo de Luciano (c. 125-190 d. C.), estavam em pleno florescimento as doutrinas de mistério e salvação, bem como antigos e modernos oráculos (de divindades gregas ou orientais), aos quais o povoléu inculto e supersticioso recorria nos seus muitos momentos de aflição. Naturalmente (o fenómeno é geral em todos os tempos...), náo faltava quem explorasse a ignorância, o irracionalismo, o medo e as ansiedades das amplas massas (e até de pessoas mais letradas), no intuito de enriquecer. Assim, proliferavam os feiticeiros e as feiticeiras, bem como os sacerdotes, profetas e oráculos de diversas religióes deste ou daquele deus (grego ou «bárbaro»).

Luciano, homem de espírito lúcido e desempoeirado, não podia compactuar com tais processos de pura charlatanice, praticados por pessoas que, para mais, se apresentavam como sábios, santos e inspirados directamente pela divindade. Mesmo entre os que se consideravam filósofos, muitos enveredavam pelas vias mais sinuosas da superstiçâo popular e por uma metafísica nada científica (v. O Mentiroso ${ }^{276}$ ). De toda essa classe influente (fazedores de opinião e de sentimentos), salvavam-se uns quantos pensadores, que tomavam por missão sagrada esclarecer as pessoas e apetrechá-las contra todos esses embustes. Entre eles, Luciano refere, com muita frequência, os filósofos cínicos (Diógenes, Menipo) e os atomistas (Demócrito, Epicuro e seus seguidores).

A personagem central deste panfleto, Alexandre de Abonotico, exerceu, entre 150 e 170 d. C., nesta cidade da Paflagónia (Ásia Menor) o seu ministério de profeta de Asclépio. A fim de abranger clientela muito diversa, apresentava-se náo só (nem principalmente) como curandeiro, mas também como conselheiro, adivinho do futuro e profeta. Para chegar a esse grau de fama e... proveito, teve de fazer um percurso lento, mas firme, pontuado das maiores indignidades.

Esta figura está bem atestada em moedas e inscriçóes, e a sua fama propagou-se por toda a Ásia Menor, Mediterrâneo, Grécia, Gália... e estendeu-se até à própria Roma. Da sua vida, propriamente, as únicas coisas que sabemos são as transmitidas neste panfleto de Luciano, seu acérrimo adversário mesmo

${ }^{276}$ Ediçōes Colibri, Colecção MARE NOSTRUM). 
antes de o conhecer pessoalmente, mas, sobretudo, depois de ter sofrido da parte do "profeta" um grave atentado contra a sua vida (v. $\$ 55-57$ ).

Assim, esta biografia póstuma é, antes de mais, uma vingança de Luciano contra o seu mortal inimigo, escrita, uns dez anos depois da morte de Alexandre, a pedido do seu amigo Celso, que havia escrito uma ou mais obras contra o Cristianismo. Uma delas, escrita entre 178 e 180, a Palavra Verdadeira mereceu, mais tarde, a resposta de Orígenes intitulada Contra Celsum, que nos informa, passo por passo, do conteúdo daquela obra de Celso.

Tratando-se, como se disse, de um panfleto escrito por um inimigo de Alexandre, pergunta-se que valor histórico deve atribuir-se a esta obra. Â falta de outra informação, podemos aceitar o facto de Alexandre se comportar como muitos outros profetas e adivinhos da sua época. Por outro lado, a menção precisa de personagens e os abundantes episódios narrados apontam para uma personagem tenebrosa, que conhecia bem a alma da gente simples e se aproveitava disso para explorá-la. Parece claro que Luciano força muitas vezes os factos e, de qualquer modo, só menciona os casos gritantes de charlatanice.

Esta biografia traz-nos à memória, significativamente, os diversos retratos de Sócrates: por um lado, a figura do filósofo tal como nos é apresentada pelos seus discípulos Platão e Xenofonte, nitidamente uma «fotografia retocada» do Mestre; e, por outro lado, a "caricatura» desenhada por Aristófanes nas Nuvens. Ambas figuram traços verídicos da mesma personagem, mas aqui devemos notar que o Sócrates das Nuvens é o "primeiro Sócrates", devotado às ciências da Natureza, ao passo que o de Platão e Xenofonte é o "último Sócrates», o filósofo das Ideias: as duas figuras não se sobrepóem no tempo, mas ambos os Sócrates são retratados segundo os sentimentos e os objectivos dos seus autores. Se possuímos duas obras intituladas Apologia de Sócrates (melhor: Discurso de Defesa Pronunciado por Sócrates), respectivamente de Platão e Xenofonte, falta-nos a Acusação de Sócrates (i. é, o Discurso de Acusação Pronunciado contra Sócrates), que foi escrita e publicada por um tal Polícrates... mas não chegou até nós: com os devidos cuidados, servir-nos-ia para procedermos a uma espécie de acareaçáo entre os dois pontos de vista. 
De toda a maneira, a biografia que Luciano traça de Alexandre, além de conter factos concretos, na generalidade fora de dúvida, constitui, sobretudo, um documento, agora sim, histórico, do estado de espírito das massas ignorantes, que acreditavam cegamente nos muitos charlatáes que a exploravam. $\mathrm{Na}$ mesma ordem de intençóes, podemos ainda citar uma outra obra de Luciano, O Mentiroso, acima mencionada.

Para o leitor moderno, há que reter a ideia da modernidade deste panfleto, numa época - a nossa - em que impera a irracionalidade e o acriticismo popular (e até... erudito) relativo a diversas pseudociências que aparecem propagandeadas por esses jornais... e têm freguesia. Não há quem os extermine? Luciano, no seu tempo, bem o tentou. 
(Página deixada propositadamente em branco) 
ALEXANDRE ou O FALSO PROFETA 
(Página deixada propositadamente em branco) 


\section{Alexandre ou O Falso Profeta}

1. Talvez tu imagines, meu caro Celso, que me impuseste uma tarefa fácil e insignificante, ao solicitares-me que reduza a escrito e te envie a biografia do impostor Alexandre de Abonotico, com todas as suas artimanhas, o seu descaramento e as suas prestidigitaçôes. Ora, pretender historiar cada episódio com toda a minúcia não é tarefa menor do que descrever os feitos desse outro Alexandre, o filho de Filipe: tamanha é a perversidade de um como a grandeza do outro. Mesmo assim, se te dispuseres a ler-me com indulgência e a preencher as lacunas da minha narração, aceitarei o teu desafio e tentarei limpar o curral de Áugeas, se não todo, pelo menos na medida das minhas forças, carregando cá para fora uns quantos cestos [de esterco], de forma que, pela amostra, possas julgar da grandeza do todo e como era indescritível a quantidade de esterco que três mil bois foram capazes de fazer em muitos anos.

2. Todavia, sinto vergonha por nós ambos, por ti e por mim: por ti, ao julgares digno de ser entregue à memória e à escrita um homem do mais execrável que há; e por mim, ao gastar o meu esforço com uma história dessas e com os actos de um homem que náo merece ser dado à leitura das pessoas cultas, mas antes ser visto num grande teatro apinhado de público e ser despedaçado por macacos ou raposas. Em todo o caso, se alguém nos lançar essa acusação, poderemos referir-lhe como exemplo um acontecimento semelhante. De facto, Arriano, discípulo de Epicteto, varão romano dos mais ilustres e que durante toda a vida se dedicou às letras, tendo-se passado o mesmo com ele, viria em nosso socorro, pois também ele considerou digna de ser contada a vida do salteador Tilóboro. Ora, nós propomo-nos conservar a memória de um salteador muito mais cruel, tanto mais que ele praticava os seus assaltos, não nos bosques ou nas montanhas, mas nas cidades; não percorria apenas a Mísia ou o Monte Ida, nem devastava apenas umas quantas partes mais desertas da Ásia, mas enchia, por assim dizer, todo o Império Romano com os seus assaltos.

3. Antes de mais, vou fazer-te um desenho verbal da personagem, representando-o o mais fielmente que for capaz, 
embora eu não seja lá muito bom desenhador. No que toca ao físico (para te mostrar também este aspecto), era alto e de bela aparência, na verdade até divinamente imponente, de tez clara, barba náo muito espessa, com cabeleira em parte natural, em parte postiça, mas muito semelhante [à natural], a ponto de a maioria das pessoas não se aperceber de que não era dele próprio. Os olhos tinham um brilho cintilante e divino; a voz era muito suave e sonora. Numa palavra, não tinha, neste aspecto, qualquer defeito que se lhe apontasse.

4. No aspecto físico, era assim. No que respeita, porém, ao seu espírito e ao seu carácter... Ó Héracles afastador de desgraças! Ó Zeus tutelar! Ó Dioscuros salvadores! Antes cair nas mãos de adversários ou de inimigos pessoais do que ter contacto com tal fulano ${ }^{277}$. Na verdade, ele superava largamente qualquer outra pessoa em inteligência, sagacidade e astúcia; e no que respeita a curiosidade, facilidade de aprender, memória e aptidáo natural para o estudo, tudo isso ele possuía no mais elevado grau, mas fazia o pior uso dessas qualidades, pois, tendo ao seu dispor estes nobres instrumentos, em breve se tornou, em perversidade, muito superior aos mais famigerados criminosos, muito acima dos Cercopes, de Euríbato, de Frinondas, de Aristodemo ou de Sóstrato. Este indivíduo, uma vez, escrevendo a seu genro Rutiliano, e referindo-se muito modestamente a si mesmo, reclamava-se igual a Pitágoras. Ora - e que Pitágoras me perdoe, esse homem sábio e de inteligência divina -, se o filósofo tivesse vivido no tempo deste fulano, de certeza que pareceria uma criança em comparação com ele. Pelas Graças!, não julgues que digo isto para ofender Pitágoras ou que estou tentando comparar em pé de igualdade os feitos de ambos. Pelo contrário, se reuníssemos as mais graves e mais ímpias calúnias que se dizem a respeito de Pitágoras (que eu não tomaria por verdadeiras), estas, todas juntas, constituiriam uma parte mínima da astúcia de Alexandre. Numa palavra: imagina e forma no teu pensamento a imagem de uma mistura muito diversificada de uma alma composta de mentira, fraudes, perjúrios e malícia, sem escrúpulos, insolente, audaciosa, diligente na execução dos seus planos, persuasiva, geradora da confiança

277 Outra interpretação (com emenda da lição do manuscrito, seria: "Oxalá os meus inimigos e adversários encontrem e tenham contacto com tal pessoa». 
dos outros, imitadora hipócrita da virtude e dando a aparência completamente oposta aos seus verdadeiros propósitos. De facto, não houve ninguém que, ao primeiro contacto com ele, não saísse dali com a opinião de que ele era o mais honesto e o mais virtuoso dos homens, e, além disso, o mais simples e mais despretensioso. A tudo isto acrescia um ar de grandeza e um espírito que não se ocupava de coisas mesquinhas, mas que, pelo contrário, estava constantemente aplicado a assuntos transcendentes.

5. Sendo ainda muito jovem, e extremamente belo, como se podia $^{278}$ avaliar pelo que ainda lhe restava ${ }^{279}$ e pelo testemunho que ouvi de outras pessoas, costumava prostituir-se descaradamente e ter relaçóes, a troco de dinheiro, com quem lho solicitasse. Entre outros, teve por amante um charlatáo, um daqueles que se gabam de conhecer as artes mágicas e fórmulas miraculosas, obter favores das pessoas amadas e má sorte para os inimigos, ou descoberta de tesouros e recebimento de heranças. Este fulano, vendo nele um rapaz esperto, perfeitamente disposto a ajudá-lo nas suas actividades e não menos apaixonado pelas suas trafulhices do que ele pela formosura do moço, instruiu-o muito bem e utilizava-o constantemente como assistente, ajudante e acólito. $\mathrm{O}$ dito sujeito era também uma espécie de médico público, mas que, tal como a mulher do egípcio Ton, conhecia

muitas drogas e misturas salutares, e muitas outras nocivas,

que o jovem recebeu como herdeiro e sucessor. Esse seu mestre e amante era natural de Tiana e um dos amigos muito íntimos de Apolónio e do círculo dos que conheciam toda a sua encenação "trágica». Já estás a ver de que escola provinha a criatura a que me refiro.

6. Já a barba lhe cobria o rosto, quando Alexandre, vendo-se, por morte desse tal tianense, em situação difícil (ao mesmo

${ }^{278}$ Podia: o imperfeito justifica-se pelo facto de, no momento em que Luciano escreve, o biografado já estar morto.

${ }^{279}$ Lit. ${ }^{\text {te }}$, "pela palha», imagem sem correspondência exacta em port.: pela palha que resta, depois de ceifado o trigo, ainda pode ver-se a qualidade da colheita. 
tempo que já lhe murchava a flor da juventude, que até então lhe permitia subsistir), pôs de lado planos tacanhos e, tendo-se associado a um certo bizantino, autor de cantos corais ${ }^{280}$, daqueles indivíduos que entram em concursos públicos, fulano de carácter ainda mais execrando que o dele (um tipo alcunhado, julgo eu, de Coconas ${ }^{281}$ ), começaram a percorrer a regiáo, ludibriando as pessoas, fazendo passes de magia e "tosquiando os parvos" (como eles próprios, na gíria dos magos, se referem ao vulgo). Foi assim que tendo encontrado uma macedónia, mulher rica, já passada da idade, mas ainda apetitosa ${ }^{282}$, não só começaram a viver à sua custa, mas também a seguiram da Bitínia para a Macedónia. Essa mulher era natural de Pela, cidade $^{283}$ outrora florescente, nos tempos dos reis macedónicos, mas actualmente modesta e com muito poucos habitantes.

7. Aí, tendo visto umas serpentes enormes, muito mansas e dóceis, de tal modo que até eram alimentadas por mulheres, dormiam com crianças, deixavam-se pisar, não se enfureciam quando as apertavam fortemente e mamavam na teta juntamente com os bebés (existem lá muitas desta espécie, donde provavelmente se originou a lenda a respeito de Olimpíade: quando esta estava grávida de Alexandre, uma serpente - creio que desta espécie - dormia com ela)... então compram, por uns poucos de óbolos, um destes répteis, o mais belo.

8. Ora, como diz Tucídides, "foi este o princípio da guer$\mathrm{ra}^{284} »$. De facto, estes dois patifes, extremamente audaciosos e dispostos a juntarem-se para o crime, facilmente compreenderam que a vida dos homens é dominada por estes dois tiranos, a esperança e o medo, e que aquele que fosse capaz de utilizar convenientemente cada um destes sentimentos enriqueceria rapidamente. $\mathrm{Na}$ verdade, verificaram que, para ambos os tipos de pessoas - os que temem e os que esperam -, a previsão [dos acontecimentos] era uma coisa absolutamente essencial e altamente desejada, e que fora deste modo que, há muito, não só

${ }^{280}$ Alguns editores lêem khronográphos "cronista ", "analista».

${ }^{281}$ A alcunha significa "pinháo»...

${ }^{282}$ Noutra interpretação, «desejosa de ser amada», «dada aos amores»...

283 O texto diz «regiáo», que, naturalmente, inclui a cidade.

${ }^{284}$ Esta frase do livro II de Tucídides está aqui, naturalmente, em sentido metafórico $=$ «foi aqui que tudo começou». 
Delfos, mas também Delos, Claros e os Brânquides ${ }^{285}$ tinham enriquecido e se tinham tornado famosos por meio destes dois tiranos dos homens (a que acima me referi - a esperança e o medo -), os quais se dirigiam aos santuários movidos pela necessidade de conhecer o futuro e que, para tal, sacrificavam hecatombes e ofertavam lingotes de ouro. Assim, após discutirem longamente sobre o assunto, e encarando as várias hipóteses, decidiram fundar um santuário e um oráculo: esperavam, se o negócio lhes corresse bem, ficar ricos e prósperos em pouco tempo - o que de facto aconteceu para além das suas primeiras expectativas e se revelou muito acima do que esperavam.

9. Desde logo, começaram a fazer planos: em primeiro lugar, sobre a região, e, em segundo lugar, sobre o arranque e o carácter da empresa. Coconas considerava a Calcedónia uma região adequada e propícia, por ficar próxima da Trácia e da Bitínia e não muito longe da Ásia e da Galácia e de todos os povos em volta. Alexandre, por seu lado, preferia a sua pátria, argumentando - e estava certo - que, para iniciar um empreendimento daqueles, precisavam de pessoas broncas, néscias e crédulas $^{286}$, como eram - segundo afirmava - os Paflagónios da vizinhança de Abonotico, na sua maior parte supersticiosos e ricos: bastava que lhes aparecesse alguém levando na frente um flautista, ou um timpanista, ou um tocador de címbalo, adivinhando o futuro - como sói dizer-se - por meio de uma peneira, para logo acorrerem todos, de boca aberta e de olhos arregalados, como se ele fosse um enviado dos deuses.

10. Depois de uma não pequena discussão ${ }^{287}$, acabou por prevalecer a ideia de Alexandre. Então, tendo chegado a Calcedónia - pois, apesar de tudo, Alexandre pensou que essa cidade lhes era de alguma utilidade -, aí, no templo de Apolo, que é o mais antigo de Calcedónia, enterraram umas plaquetas de bronze que diziam que muito em breve Asclépio, juntamente com seu

${ }^{285}$ Sacerdotes que se diziam descendentes de Brancos, filho de Apolo, que dirigiam um santuário perto de Mileto (Ásia Menor).

${ }^{286}$ Dois sentidos possíveis: "dispostas a acolher (um estrangeiro...»), i. é «hospitaleiras» ou «dispostas a aceitar (uma ideia...)», donde «ingénuas», "crédulas». O $2^{\circ}$ sentido está mais de acordo com o contexto.

287 Os manuscritos dizem: «depois de uma pequena discussão». A emenda do filólogo Hermann (que aqui acolhemos) não era absolutamente necessária. 
pai Apolo, se deslocariam à região do Ponto e se estabeleceriam em Abonotico. Estas plaquetas, adrede descobertas, fizeram que esta história se espalhasse rapidamente por toda a Bitínia e pelo Ponto, e por Abonotico mais que por todas as outras regióes. E de facto, os abotonicenses votaram a edificação de um templo, e já estavam mesmo a abrir os alicerces. Entretanto, Coconas fica em Calcedónia, compondo oráculos duplos, equívocos e obscuros, mas terminou aí os seus dias, mordido - segundo creio - por uma víbora.

11. Alexandre avança, já então provido de uma grande cabeleira aos caracóis e vestido com uma túnica de púrpura às riscas brancas e com um alvo manto sobre os ombros, empunhando uma cimitarra à maneira de Perseu, do qual se dizia descendente por parte da mãe. E os pobres dos Paflagónios, que sabiam muito bem que ambos os seus progenitores eram pessoas obscuras e humildes, acreditaram no oráculo, que dizia:

Perseida de descendência, caro a Febo, este que vedes, o mui divino Alexandre, do sangue de Podalirio.

Este Podalírio, pelos vistos, era de sua natureza, tão lascivo e perdido por mulheres, que veio de Trica para a Paflagónia, a fim de satisfazer o cio com a mãe de Alexandre.

Também tinha sido encontrado um oráculo, dado como uma profecia da Sibila:

Nas margens do Ponto Euxino, muito perto de Sinope, em Tirse, sob os Ausónios, um profeta nascerá:

Partindo da unidade, e depois três vezes dez, mais cinco outras unidades, e três vezes a vintena, ai tens em quatro letras, ao seu nome semelhante, ao do homem teu protector - andrós alex...etêros. ${ }^{288}$

12. Pois bem: entrando na sua pátria com tão grande aparato e depois de longa ausência, Alexandre tornou-se notável e famoso, ao simular, algumas vezes, ataques de loucura sagrada e deitando espuma pela boca. Este truque era muito fácil,

${ }^{288}$ Os números eram representados por letras; assim, no caso presente, temos: $\alpha^{\prime}=1 ; \lambda^{\prime}=30(23 \times 10) ; \varepsilon^{\prime}=5 ; \xi^{\prime}=60(3 \times 20)$, o que dá $\alpha \lambda \varepsilon \xi$ (alex), completado por $\alpha \nu \delta \rho o ́ \varsigma$, mais a terminação - $\eta \tau \hat{\eta} \rho$ os (-êtêros), que sugere $\sigma \omega \tau \hat{\eta} \rho \circ \varsigma$ (sôtêtos), "salvador». Mesmo para mau entendedor... 
bastando mascar raiz da saponária, planta usada em tinturaria. Mas os espectadores tomavam aquela espuma como algo de sobrenatural e estarrecedor. Além disso, desde há muito que [ele e o sócio ${ }^{289}$ ] tinham fabricado, em linho, uma cabeça de serpente com uma certa semelhança antropomórfica, bem pintada e muito bem desenhada, a qual, por meio de crinas de cavalo, abria e fechava a boca e projectava uma língua negra e bífida, como as serpentes, também pelo mecanismo das crinas. Além disso, a tal serpente de Pela continuava guardada para a função, alimentada em casa, destinada a ser, em devido tempo, mostrada às pessoas e a participar no espectáculo, no qual desempenharia mesmo o papel de protagonista.

13. Quando viu que já era tempo de começar, imaginou o seguinte truque: dirigiu-se, pela calada da noite, aos alicerces do templo, que estavam precisamente a ser abertos e onde se havia juntado uma certa quantidade de água (quer infiltrada de qualquer parte, quer caída do céu), e aí depositou um ovo de ganso previamente esvaziado, que continha uma serpente recém-nascida. Meteu o ovo bem no fundo da lama e foi-se dali. Então, na madrugada seguinte, irrompendo pela praça pública todo nu, apenas com uma tanga bordada a oiro a cobrir-lhe as partes pudendas, empunhando a tal cimitarra e sacudindo a cabeleira ao vento, num grande frenesim, à maneira dos sacerdotes mendicantes da Deusa-Mãe, sobe a um altar elevado e começa logo por felicitar calorosamente aquela cidade, que ia receber a divindade em pessoa. Os espectadores (já então tinha acorrido quase toda a cidade, incluindo mulheres, velhos e rapazes) ficam estupefactos e irrompem em preces e actos de adoração. E ele, pronunciando umas palavras ininteligíveis, qualquer coisa parecida com hebraico ou fenício, espantava as pessoas, que não percebiam o que ele dizia, a não ser os nomes de Apolo e Asclépio, que ele misturava a cada passo.

14. A seguir, lançou-se numa correria para o futuro templo, dirigiu-se aos caboucos e à improvisada fonte do oráculo e, entrando na água, começou a entoar hinos em honra de Asclépio e de Apolo, com uma voz muito forte, rogando ao deus que viesse à cidade sob bons auspícios. Depois, pede uma taça, que alguém lhe dá, e, mergulhando-a habilmente, faz aparecer, misturado

289 Trata-se do supramencionado Coconas, já falecido (v. \$10). 
com água e lama, o tal ovo, no qual tinha encerrado a divindade, depois de lhe abrir uma tampa, cuja junta estava colada com cera branca e alvaiade. Então, tendo tomado o ovo nas mãos, proclamava que, naquele momento, tinha ali o próprio Asclépio. E os espectadores, já antes mui maravilhados com a descoberta do ovo dentro de água, não despegavam os olhos do que iria acontecer. Então, tendo quebrado o ovo, tomou na concha da mão a tal serpente recém-nascida. Os presentes, ao vê-la mexer-se e enroscar-se nos dedos do profeta, desataram logo em clamores, saudavam o deus e felicitavam a sua cidade; cada um, embasbacado, cumulava-o de preces, pedindo-lhe tesouros, riqueza, saúde e todos os outros bens. Então o profeta regressou novamente a casa, a toda a pressa, levando consigo o recém-nascido Asclépio, "duas vezes nascido, enquanto as restantes criaturas nascem apenas uma vez"290, nascido, neste caso, não de Corónide, nem ao menos (c' os diabos) de uma gralha $^{291}$, mas de uma gansa. Atrás dele vai o povo em massa, todos cheios de fanatismo religioso e loucos de esperança.

15. Durante alguns dias permaneceu em casa, esperando - como de facto aconteceu - que, com o espalhar da notícia, logo acorresse uma grande multidão de paflagónios. Assim que a cidade ficou cheia de pessoas, todas elas desprovidas de razáo e de bom senso, sem qualquer semelhança com os homens "comedores de pão", mas antes (tirando o aspecto exterior), em nada diferentes dos carneiros, o profeta, metido numa saleta e recostado num leito, paramentado como convém a um deus, tinha ao peito o tal "Asclépio" de Pela, que - como anteriormente disse- era [uma serpente] enorme e muito bela. Enrolou a serpente à volta do pescoço, deixando que a cauda (que era muito comprida) saísse pela parte de baixo da túnica e rastejasse parcialmente pelo cháo, apenas lhe mantendo a cabeça escondida sob o sovaco (pois o réptil suportava tudo), e mostrando a cabeça de linho de um dos lados da barba, como se a cabeça que estava à vista fosse mesmo da serpente.

${ }^{290}$ Paródia de um verso de Homero, Odisseia, XII, 22: "Duas vezes mortos, enquanto as restantes criaturas morrem apenas uma vez”.

${ }^{291}$ Há aqui um jogo de palavras intraduzível: o palavra korône "gralha» é sugerida pelo nome próprio Corônís, mãe de Asclépio. 
16. Agora imagina uma pequena sala, não muito bem iluminada nem recebendo suficiente luz do dia, e uma multidão de pessoas em tropel, agitadas, antecipadamente maravilhadas e excitadas de expectativa: logo de entrada, como é natural, parecia-lhes assombroso o facto de, em poucos dias, um pequeno réptil se transformar numa serpente de todo o tamanho, com cara de homem e, além disso, muito mansa. Mas logo eram empurrados para a porta de saída, sem tempo para observar com atenção, impelidos pela multidão que não parava de entrar, para o que tinha sido aberta uma outra porta de saída na parte de trás. Um processo semelhante, segundo se diz, foi utilizado pelos Macedónios, em Babilónia, durante a doença de Alexandre, quando este já estava gravemente doente e os soldados rodeavam o palácio ansiando por vê-lo e dizer-lhe o último adeus. Diz-se mesmo que não foi só uma vez que o patife encenou esta representação, mas muitas outras vezes, em especial se se tratava de pessoas ricas acabadas de chegar à cidade.

17. Neste ponto, meu caro Celso, para falar verdade, há que desculpar essa gente da Paflagónia e do Ponto, pessoas broncas e ignorantes, pelo facto de se deixarem enganar, mesmo tocando a serpente (coisa que Alexandre permitia a quem quisesse), ao verem, a uma luz muito fraca, a sua pretensa cabeça e a boca a abrir e fechar, pois o truque requeria mesmo [para ser descoberto] um Demócrito, ou um Epicuro, ou um Metrodoro, ou qualquer outra pessoa que possuísse um espírito resistente como aço para esse tipo de coisas, a ponto de desconfiar e imaginar do que é poderia tratar-se, e que, caso não fosse capaz de descobrir como é que o truque era feito, estivesse já previamente persuadido de que, embora o processo lhe escapasse, era tudo uma fraude que não poderia nunca acontecer realmente.

18. A pouco e pouco, a Bitínia, a Galácia e a Trácia começaram a acorrer em massa, à medida que cada visitante transmitia a boa-nova com foros de verdade, dizendo que até tinha visto nascer o deus, que depois o havia tocado, que este, em pouco tempo, se havia tornado enorme e que tinha um rosto muito parecido com o rosto humano. A juntar a isso,, fizeram pinturas, bem como imagens e estátuas, umas de bronze, outras de prata, muito bem parecidas e, é claro, com o nome que foi 
dado ao deus, pois este chamava-se Glícon, nome originado de uma ordem divina em verso, pois Alexandre havia proclamado:

\section{Eu sou Glícon, terceiro sangue ${ }^{292}$ de Zeus, farol da Humanidade.}

19. Quando foi chegado o tempo de pôr em prática o plano completo que havia concebido, ou seja, dar oráculos e fazer profecias a quem o pedisse, adoptou o modelo de Anfíloco, da Cilícia, o qual, após a morte e o desaparecimento de seu pai Anfiarau, em Tebas, deixou a sua pátria e foi instalar-se na Cilícia, onde náo se deu nada mal, profetizando também ele ${ }^{293}$ o futuro aos cilícios e recebendo dois óbolos por cada oráculo. Adoptando, pois, este modelo, Alexandre proclama a todos os que o visitam que o deus vai fazer profecias, e indicou com antecedência a data do acontecimento. Recomendou que cada pessoa escrevesse num rolo de pergaminho o que pretendia e, sobretudo, o que desejava saber, que atasse o rolo e o selasse com cera, barro ou qualquer outra substância. Então ele próprio recebia os rolos e descia ao santuário (pois, por esta altura, já o templo estava construído e o cenário preparado), dizendo que chamaria por ordem, através de um arauto e de um clérigo, os que tinham entregue os rolos e que, à medida que ouvisse o deus a respeito de cada caso, devolveria o rolo, selado tal e qual estava, tendo na parte de baixo escrita a resposta, em termos explícitos ${ }^{294}$, que o deus dava àquilo que cada um perguntava.

20. Este truque, para um homem como tu, ou mesmo, se não fosse presunçoso dizê-lo, como eu, era por demais evidente e fácil de descobrir, mas, para pessoas vulgares e estúpidas, afigurava-se como uma coisa fabulosa e absolutamente fantástica. A verdade é que, tendo imaginado variadas maneiras de desfazer os selos, lia cada uma das perguntas e dava as respostas mais convenientes; depois, voltava a enrolar os rolos de papiro, selava-os e devolvia-os, com grande pasmo dos que os recebiam, que frequentemente comentavam entre si: "Como é que este homem conhecia o texto que eu lhe entreguei, selado com toda

292 Quer dizer, «terceira geração», «neto».

293 Entenda-se: «tal como seu pai (fazia em Tebas)».

${ }^{294} \mathrm{O}$ texto diz «à letra», ou "palavra por palavra». O profeta queria informar os consulentes de que náo procedia como tantos outros oráculos, que davam respostas confusas e dúbias. 
a segurança e com uma marca muito difícil de imitar, se não existisse por detrás um deus que verdadeiramente tudo sabe?»

21. "Mas então que processos eram esses" - perguntar-me-ás. Ora escuta, a fim de ficares em condiçóes de desmascarar esse género de embustes. O primeiro processo, meu caro Celso, é esse tal [bem conhecido]: com uma agulha aquecida ao rubro, derretia e retirava a parte da cera por debaixo do selo e, depois de ler o conteúdo do rolo, aquecia novamente a cera com a agulha, assim colando facilmente a cera por debaixo do linho com a que continha o selo. Outro processo é o chamado "do emplastro": este é fabricado com pez de Brútio, alcatrão, "pedra diáfana" (?) moída, cera e goma arábica. Com todos estes produtos, amassa-se uma espécie de "emplastro", que se aquece ao fogo; depois, humedecendo previamente o selo com saliva, aplica-se-lhe o "emplastro" e copia-se o molde. Seguidamente, logo que este ficava seco, abria facilmente o rolo, lia o seu conteúdo e depois punha nova cera e imprimia sobre ela o selo, como se fosse feito com uma pedra e muito semelhante ao original. Escuta ainda um terceiro processo, a juntar aos outros dois: misturando um pouco de gesso com aquela cola com que se colam os livros, e fazendo com isso uma pasta, vertia-a no selo quando esta ainda estava macia; depois retirava esta massa (que endurece rapidamente e fica mais dura que corno ou até que ferro) e utilizava-a como molde. Existem ainda outros processos inventados para obter o mesmo resultado, mas não há necessidade de os mencionar todos, para não parecer uma pessoa de mau gosto, tanto mais que tu, no livro que escreveste contra os magos (um tratado ao mesmo tempo muito belo e utilíssimo e capaz de inspirar sensatez a qualquer leitor), apresentas exemplos bastantes, muito mais abundantes do que os que aqui ficam.

22. Portanto, Alexandre pronunciava oráculos ${ }^{295}$, o que fazia com muita perspicácia, combinando probabilidade e imaginação, respondendo às perguntas de uns de forma obscura e ambígua, e às de outros de forma absolutamente ininteligível, pois era assim que ele considerava o estilo oracular. A uns, dissuadia-os ou encorajava-os, conforme se lhe afigurava e

${ }^{295}$ A palavra grega significa, simultaneamente, "pronunciar oráculos e profecias». 
presumia ser melhor; a outros receitava mezinhas e dietas, pois, como eu disse no princípio, conhecia muitos remédios salutares. Mas o que tinha a sua preferência especial eram as cítmides, designação, por ele forjada, de um certo fortificante feito à base de gordura de urso ${ }^{296}$. Quando, porém, se tratava de expectativas, prosperidade e sucessão de heranças, remetia a resposta sempre para outro dia, acrescentando: "Tudo isso ficará para quando eu quiser e Alexandre, o meu profeta, mo solicitar e rogar por vós».

23. Por cada oráculo tinha sido fixado o preço de uma dracma e dois óbolos. Náo cuides, companheiro, que esta pequena quantia lhe proporcionava um magro rendimento, mas ganhava por ano até setenta ou oitenta mil, pois havia pessoas tão insaciáveis, que requeriam dez ou mesmo quinze oráculos de uma assentada. No entanto, este rendimento não ia apenas só para ele, nem servia para amealhar, pois, como tinha ao seu serviço muitos assistentes, criados, informadores, fazedores e guardas de oráculos, escrivães, fazedores de selos e intérpretes, por todos eles distribuía dinheiro, a cada um segundo o seu mérito.

24. Além disso, também enviava emissários ao estrangeiro, a fim de espalharem por esses povos a fama do oráculo e contarem como ele fazia profecias, descobrira escravos fugitivos, desmascarara ladróes e salteadores, indicava onde estavam tesouros enterrados, curara doentes e até ressuscitara mortos. Deste modo, verificava-se grande correria e afluência de gente vinda de toda a parte, que fazia sacrifícios e ofertas votivas e pagava em dobro ao profeta e discípulo do deus, pois tinha sido divulgado um oráculo que dizia:

Ordeno-vos que honreis o meu servo e meu profeta: prezo mais o meu intérprete que prezo as vossas ofertas.

25. Como, porém, já começavam a insurgir-se contra ele muitas pessoas de bom senso, como se tivessem saído de uma profunda embriaguez, entre as quais se contavam sobretudo os seguidores de Epicuro, e como, pouco e pouco, iam sendo postas a nu toda aquela charlatanice e encenação teatral, Alexandre lança

${ }^{296}$ Outros manuscritos dizem "gordura de cabra». 
contra eles um espantalho, dizendo que o Ponto estava cheio de ateus e de cristáos, que ousavam proferir a seu respeito as piores blasfémias, e aconselhava as pessoas a expulsá-los à pedrada, se quisessem que o deus lhes fosse propício. Especialmente contra Epicuro, chegou mesmo a proferir um oráculo do mesmo teor; e quando alguém lhe perguntava o que é que Epicuro fazia no reino de Hades, dizia:

De plúmbeas grilhetas carregado, num lodaçal imundo está jazente.

Depois disto, ainda te admiras com o facto de o seu oráculo gozar de grande consideração, ao veres as perguntas táo inteligentes e eruditas que os visitantes faziam?

Resumindo, tinha declarado a Epicuro uma guerra sem trégua e sem quartel ${ }^{297}$, como é fácil de compreender. Sim, a que outra pessoa é que um charlatão, um amigo da imposturice e inimicíssimo da verdade, poderia com mais fundamento fazer guerra, do que a Epicuro, que via claramente a natureza das coisas e o único que conhecia realmente a verdade? Quanto aos adeptos de Platáo, de Crisipo e de Pitágoras, mantinha com eles relaçōes de profunda amizade; mas o «indobrável» Epicuro - era assim que ele o denominava - era o seu pior inimigo, e com razão, pois punha a ridículo e troçava de todos os seus truques. Por isso, entre todas as cidades do Ponto, odiava especialmente Amástris, pois sabia que nessa cidade residiam muitos adeptos de Lépido e outros da mesma laia que esses. Por isso, nunca proferiu qualquer oráculo para um amastriense. Quando, numa ocasiáo, se atreveu a proferir um oráculo para o irmáo de um senador, teve de se retirar vergonhosamente, por não ter acha$\mathrm{do}^{298}$ nem ter podido ele próprio compor um oráculo apropriado nem ter arranjado quem fosse capaz de lhe fazer um em tempo oportuno. Foi o caso que o consulente se queixava de uma dor de estômago; então, querendo receitar-lhe que comesse perna de porco cozinhada em água de malvas, disse:

${ }^{297}$ Literalmente: "não declarada".

${ }^{298}$ Entenda-se: já feito. Note-se que Alexandre, como tantos outros, dispunha de uma vasta colecção de oráculos já redigidos, donde, sem perda de tempo e de trabalho de elaboraçáo, escolhia o mais apropriado a cada caso. 
26. Muitas vezes, como disse atrás, mostrava a serpente a quem quisesse vê-la, não toda, porém, mas expondo especialmente a cauda e o resto do corpo, mantendo-lhe invisível a cabeça, escondida no sovaco. Ora, querendo maravilhar ainda mais a multidão, prometeu mostrar o deus a falar e a proferir oráculos em pessoa e sem a intermediação do profeta. Depois, cosendo umas às outras, sem a menor dificuldade, traqueias de grou, fê-las passar por dentro da outra cabeça, aquela que ele fabricara com muita semelhança; então, respondia às perguntas que lhe faziam, por meio de uma pessoa colocada lá fora a falar e fazendo passar a voz através daquele Asclépio de pano.

Estes oráculos, denominados autófonos, não eram dados a toda a gente indiferentemente, mas somente às grandes personalidades, aos ricos e aos que davam grandes presentes.

27. Por exemplo, o oráculo dado a Severiano ${ }^{300}$ a respeito da invasão da Arménia era um desses oráculos autófonos. Incitando-o à invasão, disse:

Partos e Arménios vergados à tua lança aguçada, a Roma regressarás e às nobres águas do Tibre, ostentando em tua fronte a coroa radiada ${ }^{301}$.

Severiano, esse tolo celta, deu-lhe ouvidos e procedeu à invasão, mas acabou derrotado e despedaçado por Ósroes, juntamente com o seu exército. Então Alexandre faz desaparecer este oráculo do seu arquivo e póe lá outro no seu lugar:

Melhor é que não conduzas as tropas contra os Arménios, não vá algum inimigo, com seu traje feminino, de seu arco disparar contra ti golpe funesto, que a vida te arrebate bem como a luz dos [teus olhos.

${ }^{299}$ Vê-se bem o ilogismo... mas era mesmo assim.

${ }^{300}$ Governador da Capadócia, invadiu a Arménia em 161 d. C., sendo completamente derrotado.

301 Trata-se de uma coroa com uma auréola irradiante; outro tipo era a coroa de louro. 
28. Na verdade, tinha imaginado este processo muito esperto, que consistia em fabricar oráculos posteriores aos factos, a fim de emendar as previsóes que havia feito e que tinham dado errado. Muitas vezes, antes da morte dos doentes, anunciava-lhes a cura, mas, se a pessoa morria, tinha logo ali à mão, já preparada, outra versáo do oráculo:

Não busques nunca remédio para doença fatal:

teu destino está traçado, não poderás evitá-lo.

29. Ora, sabendo que os oráculos de Claro, de Dídimos ${ }^{302} \mathrm{e}$ de Malo também eram muito apreciados por uma actividade divinatória idêntica à sua, fazia por torná-los seus amigos, enviando-lhes muitos consulentes, com estas palavras:

Dirige-te já a Claro, a fim de ouvires meu pai.

Ou então:

Vai ao santuário dos Brânquides e escuta seus oráculos.

E ainda:

Póe-te a caminho de Malo, ouve a palavra de Anfíloco.

30. Tudo isto se passava numa zona que se estendia até à Jónia, à Cilícia, à Paflagónia e à Galácia. Mas como a fama do oráculo se propagasse até à Itália e tivesse mesmo invadido a cidade de Roma, não havia ninguém que não acorresse a ele, em grande massa, uns em pessoa, outros através de emissários, especialmente os mais poderosos e os que tinham maior posição na cidade, o primeiro e mais importante dos quais foi Rutiliano, varão a todos os títulos ilustre e com provas dadas em muitas funções da administraçáo romana, mas, no que respeitava aos deuses, profundamente supersticioso e crente nas coisas mais disparatadas a seu respeito. Bastava ver em qualquer parte uma pedra besuntada com óleo ou adornada com uma coroa de flores, que logo se punha de joelhos, a adorava e, assim prostrado durante muito tempo, lhe dirigia preces e lhe rogava as maiores graças para a sua pessoa.

${ }^{302}$ V. Luc., Astr. 23. 
Ora, este indivíduo, ao ouvir falar de tal oráculo, pouco faltou para abandonar o cargo de que estava investido e voar para Abonotico. No entanto, enviou emissários atrás de emissários. Ora estes, pessoas incultas e simples servos, eram facilmente iludidos e, ao regressarem, contavam não só o que tinham visto, mas também, como se tivessem visto, aquilo que apenas tinham ouvido dizer, ainda por cima exagerando muito os factos, a fim de ficarem bem vistos aos olhos do patrão. Deste modo, inflamavam o espírito do pobre velho e induziam-no em forte loucura.

31. Ora, Rutiliano, que tinha muitos e poderosos amigos, ia-lhes passando a palavra, mas contando não só da forma como tinha ouvido da boca dos emissários, mas também acrescentando outras coisas por sua conta. Deste modo, inundou e agitou a cidade com essas notícias e transtornou a maior parte das pessoas do seu círculo, que logo se apressaram a ir escutar pessoalmente o oráculo sobre alguma coisa das suas vidas.

Então Alexandre recebia muito cordialmente os forasteiros e, por meio de um acolhimento hospitaleiro e de presentes magníficos, fazia-os ficar com boa impressão da sua pessoa, após o que se despedia deles, que não só iam divulgar as perguntas [e respostas], mas também glorificavam o deus, chegando até a mentir a respeito dos milagres operados pelo seu oráculo.

32. Mas o grande patife utilizava ainda um processo nada mal imaginado, que não lembrava a um criminoso vulgar: se, ao desenrolar e ler os papiros, previamente amolecidos, deparava com alguma pergunta melindrosa ou comprometedora para o consulente ${ }^{303}$, retinha-a em seu poder e não a devolvia, a fim de, através do medo, manter sob o seu domínio e, digamos mesmo, em escravidão os que tinham enviado as perguntas, pelo simples facto de se lembrarem do teor das perguntas que haviam feito. Podes imaginar ${ }^{304}$ que perguntas era natural que os ricos e muito poderosos lhe apresentassem. Assim, recebia muitas oferendas dessas pessoas, que sabiam muito bem que ele as tinha na sua rede.

303 para o consulente depreende-se do contexto, como se vê a seguir.

${ }^{304}$ Recorde-se que Luciano está a escrever para o seu amigo Celso. 
33. Agora proponho-me contar-te alguns dos oráculos dados a Rutiliano. Tendo-lhe este perguntado, a respeito de um filho que tinha tido da anterior esposa e que estava na idade de ser educado, que mestre lhe indicava para os seus estudos, respondeu:

Pitágoras e o ilustre aedo de pelejas narrador ${ }^{305}$.

Ora, como o rapaz tivesse morrido passados poucos dias, Alexandre ficou em apuros, sem saber como responder aos que o criticavam, pois o oráculo havia sido claramente desmentido. Mas foi o bom do próprio Rutiliano que veio em defesa do oráculo, ao dizer que o deus predissera esse acontecimento, e que por isso mesmo não o aconselhara a escolher para mestre do rapaz nenhuma personagem viva, mas sim Pitágoras e Homero, há muito tempo mortos, com os quais, naturalmente, o jovem estava agora a conviver no reino de Hades. No fundo, poder-se-ia censurar Alexandre pelo facto de ele entender por bem gastar o seu tempo com semelhantes criaturinhas?

34. Uma vez, tendo-lhe perguntado de quem é que ele, Rutiliano tinha herdado a alma, respondeu:

Primeiro nasceste Peleida, foste em seguida Menandro, depois o que agora és, serás mais tarde raio de sol, e oitenta meses lunares viverás, mais outros cem.

No entanto, Rutiliano morreu de figadeira ${ }^{306}$ aos setenta anos, sem esperar pela promessa do deus.

35. Ora, este oráculo era, ainda por cima, autófono.

De outra vez, tendo-lhe Rutiliano feito uma pergunta sobre o seu próprio casamento, respondeu explicitamente:

Consorcia-te com a filha de Alexandre e de Selene $e^{307}$.

De facto, Alexandre havia posto a correr a fama de que a filha que ele tinha nascera da sua relação com Selene. Fora

$305 \mathrm{O}$ ilustre aedo narrador de guerras é Homero.

306 Lit. "de bílis negra», talvez de cirrose; outra possibilidade: "de loucura», "louco».

307 Selene = Lua. V. infra. 
o caso que Selene, uma vez, ao contemplá-lo a dormir, ficou apaixonada por ele, pois era seu costume apaixonar-se pelos belos adormecidos. Então o inteligentíssimo do Rutiliano, sem perder tempo, mandou pedir a rapariga em casamento, celebrou as bodas e - noivo sessentão - teve relaçôes com ela, invocando a bênção da sua sogra Selene, a quem ofertou hecatombes completas, cuidando que, deste modo, também ele se havia tornado um dos deuses celestiais.

36. O mesmo Alexandre, mal se tinha apoderado do negócio na Itália, logo imaginou projectos cada vez mais ambiciosos: enviou a todos os cantos do Império Romano portadores de oráculos, nos quais advertia as cidades a que se prevenissem contra pestes, incêndios e sismos, prometendo-lhes que as protegeria eficazmente, de modo que tais calamidades não ocorressem. Por exemplo, enviou um oráculo, este autófono, a todas as naçóes, por ocasião da peste ${ }^{308}$, que dizia assim, em verso:

\section{Febo de longos cabelos afasta a nuvem da peste.}

Por toda a parte se podia ver este verso inscrito nas ombreiras das portas, como antídoto contra a peste, mas o que é certo é que ele tinha, na maior parte dos casos, o efeito contrário: por qualquer acaso, ficaram despovoadas especialmente aquelas casas em que o verso estava inscrito. Mas náo cuides que estou a afirmar que foi por causa do verso que as pessoas pereceram, pois isso sucedeu assim por mero acaso, ou talvez, também, porque muitas pessoas, confiadas nesse verso, se descuidavam e levavam uma vida muito despreocupada, não ajudando o oráculo a combater a moléstia, como se considerassem que essas simples sílabas os defenderiam e que o "Febo de longos cabelos" afastaria a peste com as suas setas.

37. Na própria Roma, Alexandre pôs como informadores muitos dos seus cúmplices, que lhe transmitiam os sentimentos das pessoas e lhe anunciavam de antemão as perguntas e, em especial, o que é que eles pretendiam saber, de forma que

${ }^{308}$ Trata-se da peste de 165 d. C., que assolou todo o Império Romano. Como Luciano escreve esta obra alguns anos (dez?) depois da morte de Alexandre, podemos datá-la de c. de 175 d. C. 
estava pronto para dar as respostas, mesmo antes da chegada dos consulentes.

38. Estas eram as artimanhas que ele executava na Itália. $<$ E na sua pátria fazia mais ou menos o mesmo $>309$. Além disso instituiu uma espécie de mistérios com procissáo à luz de fachos e rituais iniciáticos, que duravam três dias consecutivos. No primeiro dia, era feita uma proclamação, como em Atenas, pouco mais ou menos nestes termos: "Se algum ateu, cristão ou epicurista vier aqui no intuito de espiar os nossos mistérios, que seja escorraçado; e que os fiéis ao deus cumpram os rituais sob bons auspicios." E logo tinha início a expulsão, que ele próprio comandava com estas palavras: "Fora os cristãos!", ao que a multidão em peso correspondia bradando: "Fora os epicuristas!". Seguidamente, vinha o parto de Latona, o nascimento de Apolo, o casamento de Corónide e o nascimento de Asclépio. No segundo dia, representava-se a epifania de Glícon e o nascimento do deus.

39. No terceiro dia, representava-se o casamento de Podalírio com a mãe de Alexandre. Esse dia era chamado "dos fachos" [Dadis], pois nele se acendiam fachos [dádes]. Por fim, vinham os amores de Selene e Alexandre e o nascimento da esposa de Rutiliano. Naturalmente, quem empunhava o facho e presidia à cerimónia era Endímion... quer dizer, Alexandre. Enquanto este, fingia estar a dormir, ali à vista de todos, descia até ele, vinda lá do tecto, como se descida do céu, não Selene, mas uma tal Rutília, uma jovem mui formosa, mulher de um dos intendentes do Imperador, a qual estava verdadeiramente apaixonada por Alexandre e era correspondida por ele. Então, perante os olhos do imbecil marido da jovem, passava-se, à vista de toda a gente, uma cena de beijos e abraços, e, se não fosse a grande quantidade de fachos, talvez ele consumasse aquele acto que só se pratica às ocultas. Pouco depois, Alexandre entrava de novo em cena, ataviado com as vestes sacerdotais e em profundo silêncio, bradando com voz poderosa: "Ohhh Glicon!”, enquanto uns pretensos Eumólpidas e uns arautos Paflagónios, calçados com as suas botifarras e arrotando a alho respondiam: "Ohhh Alexandre!".

${ }^{309}$ Os manuscritos parecem conter uma lacuna, que alguns editores tentaram preencher, pelo que o texto, neste ponto, é algo duvidoso. 
40. Frequentemente, durante a procissão dos fachos e por entre as cabriolices místicas, deixava ver, propositadamente, a sua coxa de oiro, provavelmente coberta com uma pele pintada com tinta dourada e que brilhava ao reflexo dos fachos. Por isso, tendo, certa vez, dois sabichóes mui cretinos levantado a questão de saber se Alexandre, em vista da coxa de oiro, tinha também herdado a alma de Pitágoras, ou se apenas tinha uma alma semelhante à do filósofo, e tendo estes apresentado a pergunta ao próprio Alexandre, o rei Glícon resolveu o problema com este oráculo:

De Pitágoras a alma ora morre ora renasce.

É emanação profética do espirito divino.

O Pai no-la enviou, dos homens bons protectora.

E p'ra Zeus regressará, pelo raio de Zeus atingida.

41. Por outro lado, enquanto advertia toda a gente de que devia abster-se de relaçóes carnais com rapazinhos, por ser um acto ímpio, ele próprio - nobre homem! - inventou para seu uso este artifício: ordenou às cidades do Ponto e da Paflagónia que, de três em três anos, lhe enviassem ministros do culto, para virem ao seu santuário entoar hinos em louvor do deus. Deviam, porém, previamente examinados e seleccionados, ser enviados os mais nobres, na flor da juventude e que se distinguissem por sua formosura. Fechava-se com estes jovens e utilizava-os como objecto comprado, dormindo com eles e submetendo-os a todas as suas loucuras. Além disso, estabeleceu uma lei, segundo a qual ninguém que tivesse mais de dezoito anos podia aproximar-se dos seus lábios ou beijá-lo na boca; a esses, dava-lhes a mão a beijar, ao passo que aos mais novos beijava-os na boca. Por isso, estes eram chamados "os do beijo".

42. Era assim que ele usava e abusava dos simplórios, corrompendo sem ponta de vergonha as mulheres e abusando de jovens adolescentes. Mais: os homens consideravam uma honra muito grande e desejável que Alexandre deitasse os olhos à esposa de um deles, porquanto, se o profeta achava alguma delas digna de ser beijada, por certo que isso reverteria em boa sorte para a sua casa. Muitas mulheres até se vangloriavam de ter tido um filho dele, e os maridos juravam a pés juntos que elas falavam verdade. 
43. Agora quero contar-te um diálogo havido entre Glícon e um tal Sacerdote natural de $\operatorname{Tios}^{310}$, e de cuja inteligência tu julgarás, a avaliar pelas suas perguntas. Eu próprio li esse diálogo gravado a letras de oiro, em Tios, na casa de Sacerdote. "Diz-me lá, Senhor Glicon - perguntou Sacerdote - quem és tu?"

"Eu - respondeu Alexandre - sou um novo Asclépio, mas diferente daqueloutro, o primeiro. ${ }^{311}$ "

"Como é isso?"

"Não te é lícito saber tal coisa. ${ }^{312}$ "

"Quanto tempo permanecerás entre nós proferindo oráculos?» "Três anos e mais mil.»

"E depois para onde te mudarás?"

"Para Bactra e sua regiāo, pois os bárbaros também devem usufruir da minha presença entre eles."

"Então e os outros oráculos, como o de Dídimos, o de Claro e o de Delfos, são inspirados pelo teu pai Apolo, quando proferem os seus oráculos, ou será que são falsos os oráculos que actualmente de lá saem?»

"Não queiras conhecer isso, pois não é lícito."

"Que é que eu serei depois desta vida?"

"Primeiro, camelo; depois, cavalo; e depois, homem sábio e um profeta não inferior a Alexandre."

Este foi o teor do diálogo entre Glícon e Sacerdote. E para terminar, Alexandre proferiu este oráculo em verso, por saber que Sacerdote era um adepto de Lépido ${ }^{313}$ :

A Lépido não dês crédito, pois má sorte o acompanha.

De facto, Alexandre, como eu disse atrás, temia grandemente Epicuro, como adversário e hábil contraditor das suas trapaças.

310 Tios era uma cidade da Paflagónia. O texto tem o adj. "tiano" = "(natural) de Tios».

311 Alguns editores consideram a segunda parte uma pergunta de Sacerdote: "Mas... diferente daqueloutro, o primeiro?». O que se segue faria parte, naturalmente, da mesma fala: "Como é isso?». Entendo melhor a versão aqui apresentada.

312 O texto diz: "Nâo te é lícito ouvir tal coisa".

${ }^{313}$ Este Lépido parece ser um filósofo epicurista e, por esse facto, do total desagrado de Alexandre. 
44. Assim, fez incorrer num grave risco um certo filósofo epicurista, que se atreveu a desmascará-lo diante de testemunhas. Foi o caso que, acercando-se de Alexandre, lhe disse com voz forte: "Foste então tu, Alexandre, que induziste um certo paflagónio a levar uns criados seus à presença do governador da Galácia, para que este os condenasse à morte pelo assassinato do seu filho, estudante em Alexandria? Este, porém, está vivo e regressou a casa são e salvo, mas já depois da morte dos criados, lançados às feras por tua causa." Eis, mais ou menos, como as coisas se passaram:

Tendo o jovem navegado rio Nilo acima até Clisma ${ }^{314}$, e como nesse porto estivesse um navio prestes a levantar ferro, decidiu embarcar nele a caminho da Índia. Ora, como ele tardasse em aparecer, os desventurados criados, cuidando que o jovem tinha perecido nas águas do Nilo ou que havia sido raptado por salteadores (que nesse tempo proliferavam na região), regressaram, anunciando o seu desaparecimento. Seguiu-se o tal oráculo e a condenaçấo dos criados, após o que o jovem apareceu e narrou a viagem que fizera.

45. Assim falou o epicurista. Entáo Alexandre, irritado por se ver desmascarado, e náo suportando a verdade da crítica, ordenou aos circunstantes que o apedrejassem, sob pena de serem tidos por ímpios e lhes chamarem epicuristas. Já eles tinham começado a atirar pedras, quando um certo Demóstrato, personalidade importante do Ponto e que por acaso se encontrava na cidade, acorreu a livrar da morte o filósofo, que por pouco não era lapidado... e com muita razão $0^{315}$ : sim, que é que ele tinha que se armar em única pessoa sensata no meio de tanta gente louca, expondo-se a ser vítima da cretinice dos paflagónios?

46. A respeito deste, foi assim que as coisas se passaram. Depois disso, se por acaso, entre os consulentes chamados pela ordem em que haviam solicitado os oráculos (os quais eram redigidos de véspera), havia algum a quem, à pergunta do arauto se «havia um oráculo para Fulano», Alexandre respondia lá de dentro "Que vá para o raio que o parta», a esse, daí em diante, já ninguém o recebia em sua casa nem compartilhava com ele

${ }^{314}$ Porto egípcio nas costas do Mar Vermelho, que comunicava com o Nilo por um canal mandado abrir por Trajano.

315 É evidente que Luciano usa aqui de ironia. 
do fogo e da água, pelo que se via obrigado a errar de terra em terra, considerado ímpio, um ateu e... um epicurista -que era o maior dos vitupérios.

47. A propósito, um acto verdadeiramente ridículo foi este que Alexandre perpetrou: tendo encontrado os Princípios Fundamentais ${ }^{316}$ de Epicuro, que é, como sabes, o mais belo dos seus livros e que contém o resumo da doutrina e da sabedoria deste grande homem, levou o livro para o meio da praça pública e queimou-o em toros de figueira, como se estivesse a queimar o próprio autor, e depois lançou as cinzas ao mar, pronunciando o oráculo seguinte:

\section{Ordeno seja queimada do velho cego a doutrina.}

O malvado ignorava quão grandes benefícios esse livro proporciona aos que dele se abeiram, quanta paz, quanta tranquilidade e quanta liberdade transmite, ao libertar as pessoas de terrores, fantasmas, prodígios, vấs esperanças e ambiçóes desmesuradas, mas antes insuflando nelas inteligência e verdade e purificando verdadeiramente as suas almas, não através de tochas ardentes, de cila ${ }^{317}$ ou charlatanices quejandas, mas sim através da recta razão, da verdade e da sinceridade.

48. Entre outras audaciosas façanhas deste infame, escuta lá esta, que é a maior de todas: tendo, pelas boas graças de Rutiliano, acesso fácil ao palácio e à corte, envia um oráculo relativo à guerra na Germânia, então no auge, no tempo em que o divino [Imperador] Marco [Aurélio] ${ }^{318}$ andava envolvido em guerra contra os Marcomanos e os Quados. Esse oráculo preceituava que fossem lançados ao Istro ${ }^{319}$ dois leóes vivos, juntamente com uma grande quantidade de perfumes e magníficas oferendas. Mas é melhor citar o próprio oráculo:

${ }^{316}$ O título em grego era Kyríai Dóxai.

317 Planta liliácea bolbosa usada em medicina.

${ }^{318}$ A palavra divino indica que o imperador já tinha morrido e, portanto, havia passado à categoria divina. Em termos mais profanos significa "o falecido...".

319 Nome do Danúbio inferior. 
Na torvelinho do Istro, rio de Zeus originado, ordeno sejam lançados dois servidores de Cíbele, feras criadas nos montes, e quantas flores e drogas cheirosas cultiva o indio. E logo sobrevirá vitória e grande fama, seguida da doce paz.

Ora, tendo sido tudo isto executado tal como Alexandre ordenara, sucedeu, porém, que os leôes, salvando-se a nado, se dirigiram para a margem do lado do inimigo, onde os bárbaros acabaram com eles à paulada, tomando-os por uma espécie de cáes ou de lobos. Imediatamente a seguir, as nossas tropas sofreram uma terrível derrota, tendo perdido a vida, de uma assentada, cerca de vinte mil homen $s^{320}$. Depois, deu-se o caso de Aquileia ${ }^{321}$, em que essa cidade esteve prestes a ser tomada. Entâo Alexandre, perante este resultado, citou calmamente a célebre justificação de Delfos a respeito do oráculo dado a Creso, dizendo que o deus tinha, sim, vaticinado uma vitória, mas não declarara se seria a favor dos Romanos ou dos inimigos.

49. Mas já então multidóes atrás de multidóes acorriam à cidade de Alexandre, que começava a ficar apinhada de gente que vinha consultar o oráculo, a tal ponto que a cidade já não dispunha de víveres em quantidade suficiente. Foi então que imaginou os chamados "oráculos nocturnos»: recebia os papiros com as perguntas, dormia sobre eles (assim o afirmava) e depois respondia às consultas, como se tivesse tido um sonho inspirado pelo deus. Todavia, as respostas, na sua grande maioria, não eram claras, mas ambíguas e confusas, sobretudo se via que o papiro fora selado com especial cuidado ${ }^{322}$. Neste caso, não querendo correr riscos, escrevia na margem o que primeiro lhe vinha à cabeça, convencido de que um tal processo condizia perfeitamente com o estilo oracular. Além disso, havia uns intérpretes designados para estes casos, os quais recebiam das pessoas que obtinham tais oráculos um pagamento nada despiciendo pela sua interpretação e explicação. Esta função

${ }^{320}$ Este desastre militar e o assalto à cidade de Aquileia deram-se entre 167 e 169 d. C.

${ }^{321}$ Cidade da Ístria, ao norte da Itália, junto do Adriático.

322 Esse cuidado indicaria que se tratava de um consulente especial ou... perigoso. 
era mesmo objecto de arrematação: cada intérprete pagava a Alexandre um talento ático ${ }^{323}$.

50. Por vezes, sem que ninguém o consultasse ou lhe mandasse pedir, e mesmo sem referência a alguém em especial, emitia oráculos só para maravilhar os pacóvios, como este, por exemplo:

Queres saber quem, clandestino, copula com tua esposa.

a bela Caligenia, em teu leito, em tua casa?

É teu criado Protógenes, em quem tanto confiavas.

Este, que antes violavas, toma agora tua esposa,

assim tirando vingança do sumo ultraje sofrido.

Está pronta a droga funesta que eles pra ti destinaram,

pra que não oiças nem vejas os actos que eles praticam.

Hás-de achá-la sob o leito bem próximo da parede,

do lado da cabeceira. A serva Calipso é cúmplice.

Que Demócrito ${ }^{324}$ não ficaria perturbado ao ouvir citar com precisão nomes e lugares, mas que, logo a seguir, percebendo a manigância, repudiaria ${ }^{325}$ o oráculo?

52. ${ }^{326}$ A uma outra pessoa, que não estava presente (e que nem sequer talvez existisse), disse, em prosa: "Regressa a casa, pois a pessoa que te enviou foi hoje assassinada pelo seu vizinho Diocles, com a ajuda dos ladróes Magno, Céler e Búbalo, que já foram apanhados e estão presos."

51. Frequentemente, dava consulta mesmo a bárbaros que se lhe dirigiam na língua materna, em sírio ou em celta, pois

${ }^{323} \mathrm{O}$ talento não era moeda corrente, mas sim aquilo a que se chama «moeda de conto». Um talento equivalia a 60 minas ou 6.000 dracmas. Era uma quantia avultada, que diz bem do lucro que o negócio proporcionava a ambas as partes.

${ }^{324}$ Demócrito é, em muitos passos da obra de Luciano, o protótipo do homem racional, que náo se deixa enganar por truques de mágicos, profetas e quejandos.

325 Literalmente, o termo grego significa «cuspir para o chão», em sinal de repúdio.

${ }^{326}$ Embora mantendo a numeração tradicional, muitos editores modernos aceitam a transposição proposta pelo filólogo Fritzsche: 52 antes de 51. Em todo o caso, não nos parece que essa transposição seja absolutamente necessária. 
era fácil ${ }^{327}$ encontrar residentes estrangeiros da mesma nação dos consulentes. Devido a esse facto, era mais longo o tempo que mediava entre a entrega dos rolos e a resposta do oráculo, já que, entretanto, havia que tirar o selo com todo o vagar e cuidadosamente e, depois, encontrar pessoas capazes de traduzir cada uma das perguntas. Eis um exemplo de um oráculo dado em língua cítia:

\section{Morphên eubárgoulis eis skián khnekhikrágê leipsei pháos ${ }^{328}$.}

53. Ouve agora umas quantas respostas que me foram dadas a mim próprio. Tendo-lhe eu perguntado se Alexandre era calvo, este, notando que o rolo estava manifestamente selado com todo o cuidado, respondeu com um «oráculo nocturno» $»^{\otimes}$ :

\section{Sabardalakhou malakhaatthalos $\hat{e} n^{329}$.}

Noutra ocasião, tendo-lhe eu feito a mesma pergunta - «Donde era natural o poeta Homero" -, em dois rolos diferentes e sob diferentes nomes, a uma das consultas (enganado pelo meu jovem criado, que, interrogado para que é que ali vinha, respondera que era "para pedir a cura de uma dor nas costas»), respondeu:

\section{Besunta-te com unguento ${ }^{330}$ e espuma de corcel.}

À outra consulta (informado pelo meu criado de que o remetente perguntava se seria melhor ir à Itália de barco ou por terra) não respondeu nada que tivesse relação com Homero:

${ }^{327}$ Alguns manuscritos têm "não era fácil», o que obrigaria a ajeitar a frase para "mas não era fácil...». É difícil decidir, porquanto, sendo ou nâo fácil encontrar tradutor, a operaçáo de traduzir e responder na mesma língua sempre levava o seu tempo.

${ }^{328}$ Neste texto, reconhecem-se algumas palavras gregas - o que seria de todo em todo ilógico. Certamente que o texto original de Luciano seria mesmo em língua cítia, mas, posteriormente, os copistas sucessivos, não entendendo nada do que estava escrito, tentaram «helenizar»o oráculo. O sentido parece ser: "Morpen Eubárgoulis irá (?) para as trevas e abandonará a luz [do dia]».

${ }^{329}$ Texto completamente obscuro. Os manuscritos apresentam textos muito diferentes.

${ }^{330}$ Não é possível determinar de que espécie de unguento se tratava. 
Não vás por via marinha, viaja por terra seca.

54. Armei-lhe ainda mais algumas ciladas do mesmo género destas. Por exemplo, tendo-lhe feito uma única pergunta, escrevi, na parte de fora, como é costume, «de Fulano, oito oráculos», mas usando nome falso e enviando as respectivas oito dracmas mais os trocos para perfazer o total ${ }^{331}$. Então ele, fiado na quantia enviada para pagamento e no que estava escrito na parte de fora do rolo, enviou-me, pela única pergunta - "Quando é que Alexandre será preso por vigarice?» -, oito respostas, que, como sói dizer-se, «não tinham nada que ver nem com a terra nem com o céu ${ }^{\otimes}$, mas eram, todas elas, disparatadas e absurdas.

Quando, posteriormente, se apercebeu da minha artimanha e, além disso, que fora eu quem tentara dissuadir Rutiliano de se casar com a filha dele e de se apegar excessivamente às esperanças dadas pelo oráculo, passou, como se esperava, a odiar-me e a considerar-me o seu pior inimigo. Uma vez, tendo-o Rutiliano interrogado a meu respeito da minha, respondeu:

\section{Em relaçôes nocturnas se compraz, e em coitos desonestos.}

Numa palavra, eu era, e com razão, o seu pior inimigo.

55. Doutra vez, quando soube que eu tinha chegado à sua cidade, tendo-se certificado de que eu era o famoso Luciano (além disso, eu vinha acompanhado de dois soldados, um lanceiro e um frecheiro, designados pelo governador da Capadócia, entâo meu amigo, para me escoltarem até ao mar), apressou-se a mandar-me convidar com muita cortesia e amabilidade. Ao chegar, encontro-o rodeado de numeroso séquito, mas, por feliz acaso, eu tinha trazido comigo os soldados. Estendeume a mão direita a beijar, como costumava fazer com a maior parte das pessoas, mas eu, aproximando os lábios como se fosse beijá-la, aplico-lhe uma valente mordidela, que por pouco não lhe arrancou a mão.

Os presentes tentaram esganar-me e espancar-me como sacrílego, eles que já anteriormente se haviam indignado pelo

${ }^{331} \mathrm{O}$ preço de cada oráculo era de 1 dracma e 2 óbolos. A dracma continha 6 óbolos, pelo que os oito oráculos ficavam em 8 dracmas e 16 óbolos, ou seja, 10 dracmas e 4 óbolos. Luciano pagou 8 dracmas com moedas de 1, 2 ou 4 dracmas, e o restante em óbolos. 
facto de eu ter tratado Alexandre pelo seu próprio nome, e não por «Profeta». Ele, porém, suportando corajosamente o golpe, acalmou as pessoas e prometeu-lhes que facilmente faria de mim uma pessoa mais cordata e que, desse modo patentearia o poder de Glícon, que consegue transformar em amigos até mesmo as pessoas mais violentas. Depois, tendo mandado toda a gente embora, tentou justificar-se perante mim, dizendo que sabia muito bem quem eu era e os conselhos que eu dera a Rutiliano. E acrescentou: "Por que motivo me trataste desta maneira, quando eu, afinal, até seria capaz de aumentar a tua reputação junto de Rutiliano?». Aí eu, vendo o perigo em que incorria, aceitei de bom grado a sua amizade e, passados alguns momentos, apareci em público como seu amigo, facto que a todos pareceu um milagre, tão rápida foi a minha transformação.

56. Algum tempo depois, como eu decidisse partir (por acaso acompanhado somente de Xenofonte ${ }^{332}$, pois havia previamente mandado meu pai e outros familiares para Amástris), enviou-me lembranças e presentes, juntamente com a promessa de me fornecer um navio e respectivos remadores para me conduzissem, o que eu considerei um acto sincero e cortês. Chegados, porém, a meio da viagem, vendo o piloto a chorar e a discutir junto dos remadores, foram-se-me as boas perspectivas de futuro: era evidente que tinham recebido ordens de Alexandre no sentido de pegarem em nós e nos lançarem ao mar, o que, a ter sucedido, seria a forma mais fácil de acabar com a guerra entre nós. Por fim, o piloto, com as suas lágrimas, convenceu os companheiros a que não nos fizessem mal. E disse-me ele: "Tenho sessenta anos, como vês; ora, tendo chegado a esta idade levando sempre uma vida irrepreensivel e pura, não quereria, na minha idade e com mulher e filhos, manchar as minhas mãos com um homicídio.». E confessou a intenção com que nos havia embarcado e as ordens que recebera de Alexandre.

57. Depois desembarcou-nos em Egíalos ${ }^{33}$, mencionada pelo bom do Homero, e voltaram todos para trás.

Ali, encontrei umas pessoas do Bósforo que navegavam ao longo da costa; eram delegados do rei Êupator, que se dirigiam à Bitínia a fim de cobrarem o tributo anual. Contei-lhes o perigo que havíamos corrido, e eles, mostrando-se muito simpáticos

332 Supóe-se que seria um criado de confiança.

${ }^{333}$ Nas costas da Paflagónia. 
receberam-nos no navio e conduziram-nos sãos e salvos até Amástris, depois de ter estado tão perto de perder a vida.

Desse momento em diante, declarei guerra a Alexandre e movi todos os cordelinhos ${ }^{334}$ no intuito de me vingar, eu que já antes desta emboscada o odiava e o considerava meu grande inimigo mortal, devido à vileza do seu carácter. Assim, avancei com um processo contra ele, secundado por muitos companheiros de luta, nomeadamente os adeptos do filósofo Timócrates de Heracleia. Foi então que Avito ${ }^{335}$, ao tempo governador da Bitínia e do Ponto, me refreou, pouco faltando para me rogar e implorar que desistisse do processo, dizendo que, devido às suas relaçóes de amizade com Rutiliano, náo poderia punir Alexandre, mesmo que se provasse claramente que ele era culpado. Assim, contive o meu impulso e desisti daquela temeridade nada oportuna, tratando-se de um juiz com tal predisposição.

58. Foi ou não foi, entre outros, um grande descaramento por parte de Alexandre, aquele de ter requerido ao Imperador que mudasse o nome da cidade de Abonotico, para passar a chamar-se Ionópois? Ou de cunhar uma nova moeda com a imagem de Glícon numa face e, na outra, a de Alexandre cingindo a coroa do seu antepassado Asclépio e a famosa cimitarra de Perseu, seu ascendente por parte da máe $e^{336}$ ?

59. Embora tivesse vaticinado, em oráculo sobre a sua pessoa, que estava destinado a viver cento e cinquenta anos e que, em seguida, morreria atingido por um raio, morreu de morte miserável quando ainda náo tinha completado setenta anos, como filho que era de Podalírio, com uma perna completamente apodrecida até à virilha e fervilhando de vermes. Foi então que se descobriu que ele era calvo, pois, por causa das dores, teve de descobrir a cabeça perante os médicos, a fim de lhe aplicarem uma loção, operação impossível de executar sem lhe retirarem a peruca.

60. Foi este o desenlace da tragédia de Alexandre, foi este o triste epílogo de toda a peça, que parece mesmo obra da Providência,

${ }^{334} \mathrm{O}$ texto diz «todos os cabos» ou «todas as cordas», mas o sentido é, em grego como em português, metafórico.

${ }^{335}$ Lúcio Loliano Avito foi governador da Bitínia em 165 d. C.

336 V. $\$ 11$. 
muito embora se tenha devido ao acaso ${ }^{337}$. Depois, havia que lhe fazer um funeral digno da sua vida e abrir concurso para a sua sucessão no oráculo, pelo que os cúmplices e charlatães mais importantes se dirigiram a Rutiliano a fim de que este, na qualidade de árbitro, decidisse qual deles havia de ser escolhido para lhe suceder no oráculo e ser coroado com a coroa de sacerdote e profeta. Ora, havia entre eles um tal Peto, médico de sua profissão, já de cabelos grisalhos, que se comportava de maneira indigna quer de um médico quer de um velho. Todavia, Rutiliano, juiz do concurso, despediu-os a todos, sem lhes outorgar a coroa da vitória, mantendo para Alexandre o lugar de profeta, mesmo depois da sua morte.

61. O que aqui fica, meu caro amigo, é apenas uma pequena parte, que, a título de amostra, tive por bem escrever, não só para te ser agradável, como meu companheiro e amigo, que eu muito admiro entre todos, pela tua sabedoria, pelo teu amor da verdade, pela doçura do teu carácter, teu sentido de equidade, serenidade na vida e gentileza com aqueles que te visitam, mas especialmente - coisa que te é sumamente grata - no intuito de vingar Epicuro, homem realmente santo e de natureza divina, o único que conheceu de ciência certa o sumo bem e o transmitiu, esse libertador dos que com ele convivem. Também estou convicto de que os leitores encontrarão algo de útil neste meu escrito, que, por um lado, desmascara imposturices, e, por outro, consolida as convicçóes das pessoas de bom senso.

${ }^{337}$ Luciano expóe aqui uma ideia dos atomistas (Demócrito, Epicuro...), materialistas convictos, que defendiam a ideia de que os deuses, se existem, náo se ocupam das coisas humanas. O conceito de acaso (juntamente com o de vazio e a constituição atómica da matéria) é um dos princípios dos atomistas e epicuristas. 
PRONTUÁRIO MITOLÓGICO 
(Página deixada propositadamente em branco) 


\section{PRONTUÁRIO MITOLÓGICO}

NOTA - Naturalmente, a informação que se segue está reduzida ao minimo indispensável. O leitor interessado em mais pormenores deve recorrer a obras da especialidade, nomeadamente:

- LAVEDAN, P., Dictionnaire illustré de la mythologie et des antiquités grecques et romaines. Paris, Hachette.

- VARII, The Oxford Classical Dictionary. Oxford, Clarendon Press,

- HarveY, P., The Oxford Companion to Classical Literature. Oxford, Clarendon Press.

- Croon, J. H., Encyclopédie de l'antiquité classique. Paris-Bruxelas, Éditions Sequoia.

- SCHMIDT, J., Dicionário de Mitologia Grega e Romana. Lisboa, Edições 70, tradução de João Domingos.

- Grimal, P., Dicionário da Mitologia Grega e Romana. Ed. Difel, $4^{\mathrm{a}}$ ed., 2004. Traduçáo de Victor Jabouille et alii.

- PinheIro, Marília P. Futre, Mitos e Lendas - Grécia Antiga. Vol. I, Lisboa, "Livros e Livros", 2007 


\section{SIGLAS:}

AFP-Alexandre ou O Falso Profeta $B I-O$ Bibliómano Ignorante DC-Diálogos das Cortesâs DD - Diálogos dos Deuses
DDM - Diálogos dos Deuses Marinhos DM-Diálogos dos Mortos

SVL - O Sonho ou Vida de Luciano 
ACTÉON (DD 16) — Filho de Aristeu e de Autónoe. Grande caçador. Um dia, surpreendeu por acaso Ártemis a tomar banho. Entấo a deusa, irritada, metamorfoseou-o em veado; sob esta forma, foi despedaçado pelos seus próprios cães.

ADÓNIS (DC 7; DD 11) — Um dos grandes símbolos da beleza masculina. Filho da princesa assíria Mirra e do seu próprio avô materno. Sua mãe, envergonhada, transformou-se em árvore, de cuja casca, passado o tempo de gravidez, brotou o formoso menino Adónis, logo recolhido por Afrodite, que se apaixonou por ele e o guardou num cofre, mas teve a triste ideia de o dar a guardar a Perséfone, rainha do Hades, a qual, também encantada com a formosura do menino, se recusou a devolvê-lo. Então Zeus, chamado a arbitrar o caso, decidiu que o menino pertenceria quatro meses a cada uma das deusas, ficando os restantes quatro meses em completa liberdade, mas Adónis concedeu este tempo a Afrodite, pelo que passava um terço da vida no reino de Hades e dois terços no Olimpo. Foi morto por um javali, quando andava a caçar. Além de ser um dos símbolos da beleza, também representa a luta entre as forças da vida e da morte.

AFRODITE (DC 3; 5; 5; 11; $14 \mid D D 7$; 11; 12; 15; 17; 19; 20;23|DM 1; 7; 9; 15) (lat. Vénus) — Deusa do amor, da beleza e da fecundidade, de origem oriental, mas adoptada pelos Gregos como uma das suas principais divindades, cujo nome entendiam como «nascida da espuma das ondas»; esposa de $\mathrm{He}$ festo; amou o troiano Anquises, de cuja relação nasceu Eneias. Mãe de Eros $(11,1 ; 12$; 19); de Hermafrodito, Eros e Priapo (15,2; 23,1); amante de Ares, apanhada em flagrante por artimanha de Hefesto, seu legítimo esposo $(15,3)$; vencedora do concurso de beleza com Hera e Atena.

ALCMENA (DD 24; DM 16) - Esposa de Anfitrião, foi amada por Zeus, de cuja união nasceu Héracles.

ÂMICO (DD 26) — Rei da Bebrícia (país mal identificado); v. BÉBRICE.

Amor: v. EROS

ANQUISES (DD 11; 20) — Amado por Afrodite, dessa uniāo nasceu Eneias.

ANTÍOPE (DD 24) — Amada de Zeus, que a seduziu disfarçado de sátiro.

APOLO $(D D 2 ; 7 ; 14 ; 15 ; 16 ; 17 ; 19 ; 23$; $26|D D M 7| D M 20|B I 9 ; 11|$ AFP 10; 13; 14; 38; 43) - Um dos grandes deuses gregos. Segundo a lenda, nasceu na ilha de Delos, tal como sua irmã gémea Ártemis. Tinha importantes santuários em Claro, em Cólofon e em Dídimos e - o mais famoso - em Delfos, onde em sua honra se celebravam os Jogos Píticos. Deus curandeiro, é pai de Asclépio (q. v.). Amante infeliz de Dafne e Jacinto (q. v.); grande atirador ao arco, tocador de cítara, médico, adivinho; (16,1).

ARES (lat. Marte) ( $D D 7 ; 12 ; 15 ; 17$; 19; 20; 21) — Deus da guerra, amante de Afrodite, foi apanhado em pleno acto de adultério pelo marido de Afrodite, Hefesto... que se fartou de rir, juntamente com os outros deuses que assistiam à cena do casalinho en- 
rodilhado numa rede bem montada (17).

ARGOS (DD 3; 20) — Gigante com cem olhos (ou quatro: dois à frente $\mathrm{e}$ dois atrás), a quem, por isso mesmo, foi confiado a guarda de Io (v.). Foi morto por Hermes, que, depois de o ter adormecido ao som da flauta, lhe cortou a cabeça.

ÁRTEMIS (lat. Diana) (DD 16; 19; 23; 26) - Irmã gémea de Apolo. Deusa da natureza e da caça, mas também protectora das parturientes. "É varonil para lá da medida, muito amiga de andar pelos montes e, para concluir, quando vai à Cítia, toda a gente sabe como ela mata e devora estrangeiros".

ASCLÉPIO (Esculápio) (DD 13; 26 | AFP 10; 13-15; 26; 38; 43; 58) - Herói tessálico, que os Gregos fizeram deus da medicina, dando-lhe, como paternidade adequada, precisamente Apolo. A sua arte era tal, que chegava a ressuscitar mortos, o que irritou sumamente Zeus, que o atingiu com o seu raio. Tinha um grande número de santuários em toda a Grécia (Pausânias fala de 63), o mais famoso dos quais era o de Epidauro.

ATENA (lat. Minerva) ( $D C$ 7;9 $D D$ 9; 19; 20;21|DDM 7; 14|DM 29) - Nascida da cabeça de Zeus, armada e equipada (9), é a deusa das artes e da filosofia e protectora de Atenas. Deu aos homens o precioso presente da oliveira. Também deusa guerreira, que, sob o nome de Nikê, "Vitória», favorecia quem a invocasse.
ÁTIS (DD 12) — Companheiro de Cíbele (a Deusa-Máe) e participante nos seus mistérios. Foi amado pela velha deusa Reia.

Baco: v. DIONISO

BÉBRICE (DD 26) — nome comum: «bébrice», «da Bebrícia»; andrónimo: Bébrice, filho de Âmico, rei da Bebrícia.

BRANCO (DD 2) — Filho (e sacerdote) de Apolo.

BRIAREU (DD 21) - Gigante de cem braços, lutou ao lado de Zeus contra os Titâs.

CADMO (DD 9; 24) — Neto de Posídon, filho de Agenor; herói de origem fenícia, parte à procura de sua irmã Europa, raptada por Zeus. Depois de muito procurar, chega à Beócia, onde funda Tebas, de que se tornou rei. Casado com Harmonia, filha de Ares, dessa uniāo nasceram diversos filhos, entre os quais Sémele, mãe de Dioniso. Passa por ser o inventor do alfabeto (pela sua origem fenícia) e da metalurgia.

CÁRITE(S) (lat. Graças) (DD 15; 20) Filhas de Zeus, personificam o ideal de graça, delicadeza e perfeiçâo: Eufrósine («alegria»), Aglaia («brilho») e Talia («florescente»).

CASTOR E PÓLUX (DD 26) - Leda, esposa de Tíndaro, rei de Esparta, teve uma uniáo com Zeus, que a seduziu sob a forma de cisne. Dessa relaçāo nasceram dois... ovos: de um deles, saíram Helena e Pólux, e do outro Castor e Clitemnestra. Pólux, distinguiu-se na luta, sobretudo no pugilato, e Castor era um exímio domador de cavalos. Protectores dos homens, sobretudo como 
salvadores de náufragos. Quando chegou a hora de Castor morrer, Pólux, desde o nascimento dotado da imortalidade, fica inconsolável com o destino do irmáo, mas é-lhe concedida a graça de partilharem as duas situaçóes: alternadamente, um está no reino de Hades, e o outro encontra-se no Olimpo.

Claro(s): v. APOLO

CLÍMENE (DD 12; 25) — Uma das Oceânides. Da sua uniáo com Hélio nasceu Faetonte, jovem imprudente a quem seu pai, ainda mais imprudente, emprestou o carro puxado por fogosos cavalos.

Cólofon: v. APOLO

CORIBANTES (DD 12) - Sacerdotes de Cíbele, participavam em ritos de mistério e orgiásticos. Representam as forças irracionais.

CRONOS $(D D$ 9) - O maior dos Titâs, pai de Zeus, que engolia os filhos à nascença. Zeus, porém, escapou, pois sua mãe escondeu-o. Mais tarde, revoltou-se contra o pai e ocupou-lhe o trono.

Cupido: v. EROS

DAFNE (DD 2; 14-16|DM 28) - Bela ninfa, amada por Apolo, que a perseguiu longamente. Vendo-se quase apanhada, gritou por sua máe, Terra, tendo-se logo transformado em loureiro (gr. $\delta \alpha ́ \varphi v \eta)$, planta que passa a ser o símbolo e o prémio da vitória.

DÁNAE (DD 24| DDM 14) — Filha única de Acrísio, rei de Argos. Um oráculo declarou que Dánae daria à luz um filho que haveria matar o avô. Entáo Acrísio encerrou a filha numa prisão, bem preservada do mundo exterior, mas Zeus conseguiu lá entrar sob a forma de chuva de oiro... e Dánae foi mãe de Perseu......

DEJANIRA (DD 13) — Esposa de Héracles

Delfos: v. APOLO

Diana: v. ÁRTEMIS

Dídimos: v. APOLO

DIONISO (Baco) (DD 2; 9; 18; 22; 23 | DDM 5-6 $D M 14 \mid$ BI 11) - Filho de Zeus e de Sémele, mas, como esta tivesse morrido antes do seu nascimento (v. SÉMELE), Zeus introduziu o feto na coxa, até que se cumprisse o tempo necessário para o nascimento. Deus da vinha e do vinho, da arruaça e da desordem, anda sempre acompanhado das Ménades, das Bacantes e dos Centauros, Sátiros e Silenos. Dioniso represente a força irracional, o pulsar da natureza bruta, por oposiçáo ao pensamento racional e à ordem universal representada por Apolo.

DÓRIDE (DÓRIS) - 1. (DDM 1; 12; 14) Filha de Oceano, esposa de Nereu, donde é mãe das Nereides. | 2. (DC 2) Nome duma cortesâ $\mid 3$. (BI 15) Esposa de Dioniso, tirano de Siracusa

ECO (DD 22; DDM 1) - Ninfa, apaixonada pelo belo Narciso, mas náo correspondida, definhou de desgosto. O seu corpo, reduzido a um fantasma, habita em grutas e nas montanhas, onde não fala, mas só responde a quem se lhe dirige, mas apenas repetindo a última sílaba.

ENDÍMION (DD 11; AFP 39) — Jovem pastor por quem Selene (a Lua) se 
apaixonou, não se fartando de o contemplar enquanto ele dormia.

EROS (lat. Amor, Cupido) (DD 2; 4; 7; 12; 19; $23 \mid D M 19 ; 26)$ - Filho de Afrodite e de Ares, suscita a paixão irresistível de deuses e humanos, por meio de setas com que atinge o coração das vítimas.

Esculápio: v. ASCLÉPIO

GALATEIA (DDM 1) — Filha de Dóride e de Nereu.

GANIMEDES (DD 4; 5; 6; 9; 20) Príncipe troiano, foi escolhido por Zeus para ser seu escançáo (em substituiçáo de Hebe) e seu amante. Segundo uma versão, Zeus enviou uma águia para o raptar; outra versáo diz que o próprio Zeus se disfarçou de águia.

Gárgaro: v. Ida, monte

GÓRGONA(S) (DD 19; DDM 14) - Seres de aspecto monstruoso e aterrador, eram três irmãs - Esteno, Euríale e Medusa. Esta última, a mais famosa, é por vezes designada por a Górgona (por excelência). É representada com serpentes enleadas nos cabelos, dentes longos e aguçados como os de um javali; o seu olhar petrifica quem a fixa. | Cortesã: $D C 1$

\section{Graça(s): v. CÁRITE(S)}

HADES ou PLUTÃO (Hades: DD 6; 7; $24 \mid D M 4 ; 10 ; 13 ; 16 ; 17 ; 20$; 25; $26 \mid$ AFP 25; 33; Plutáo: $D D$ 24; $D M$ 2; 5; 6; 16; 20; 22; 23) — Rei do reino inferior (Inferno), irmáo de Posídon (rei dos mares) e de Zeus (soberano celeste), que, depois da vitória sobre os Titâs, repartiu o universo com esses seus dois irmāos. Desposou Perséfone (Prosérpina). Diz-se o reino de Hades ou o Hades para designar o Inferno.

HEBE (DD $5 \mid D M 16)$ - Deusa da juventude, era a copeira dos deuses olímpicos, mas, após o seu casamento com Héracles, foi substituída nessa função por Ganimedes

HEFESTO (DD $1 ; 5 ; 7 ; 8 ; 15-17 \mid D D M$ 10) — Filho de Zeus e de Hera. Ferreiro dos deuses, para quem fabricava armas e outros engenhos. Tenta libertar sua mãe, que, juntamente com outras deusas, havia participado numa conspiraçáo contra Zeus, pelo que este o precipita do alto do Olimpo, indo cair no mar, onde foi recolhido por Tétis. Devido a essa queda, ficou coxo, a juntar ao facto de já ser feio por natureza e, pelo ofício, andar sempre sujo e enfarruscado. Os Gregos situavam a sua oficina na ilha de Lemnos. Desposou Afrodite, a qual, no entanto, preferiu sempre o esbelto Ares. Hefesto armou-lhes uma rede, que os envolveu no leito, em pleno acto amoroso (17). Foi Hefesto que, por ordem de Zeus, rachou com um machado a cabeça do Olímpico, donde brotou Atena (13). Eventualmente, também servia de copeiro dos deuses.

HÉLIO (DD 10; 12; 17; 25) — O Sol ou o Deus-Sol, percorre todos os dias a Terra no seu carro de oiro puxado por quatro fogosos cavalos. Um dia, confiou o governo do carro a seu filho Faetonte, que, por insensatez e falta de experiência, ora se aproximava da Terra, ora se afasta- 
va, causando os maiores prejuízos, pelo que Zeus teve de intervir, atingindo o jovem com os seus temíveis raios (25). Uma vez, em que Zeus precisava de uma noite três vezes mais longa, a fim de estar com a bela Alcmena, legítima esposa de Anfitriāo, recebeu ordem de retardar a marcha.

HERA (SVL $8 \mid D D 3 ; 5 ; 6 ; 9 ; 16 ; 18 ; 20$; $21|D D M 7 ; 9 ; 11| D M 28)-$ Esposa de Zeus, ciumenta (com toda a razáo) e vingativa. V. IO (3; 5); Num concurso de beleza entre Hera, Atena e Afrodite, o juiz Páris atribui a vitória a esta última.

HÉRACLES (lat. Hércules) (SVL 17|DD 13 | DM 14; 15; 16; 23 | BI 5; 23 ( AFP 4) - Filho de Alcmena, esposa de Anfitriāo, e de Zeus, é o mais célebre, o mais forte e o mais valente dos heróis. Antes de tomar lugar entre os imortais, teve de desempenhar tarefas extremamente perigosas (os «doze trabalhos») impostos por Eristeu, rei de Micenas. 1-2: mata o leâo de Nemeia e a hidra de Lerna; 3-4: captura do javali de Erimanto e da corça de pernas de bronze de Ártemis; 5: extermina as aves do lago de Estínfalo, com bicos garras e penas de bronze e consagradas a Ares; 6: limpeza dos estábulos de Áugias, que continha três mil bois, e que Héracles só conseguiu limpar, desviando para aí os rios Alfeu e Peneu; 7: captura do touro que assolava a ilha de Creta; 8: captura das éguas de Diomedes, rei da Trácia, que lançavam fogo pelas narinas e eram alimentadas com carne humana; 9: obtém para Eristeu a maravilhosa cinta de Hipólita, rainha das Amazonas; 10: roubou os bois de Gérion, gigante de três corpos, ajudado por um câo de duas cabeças; 11: roubou as maçâs de ouro do jardim das Hespérides; 12: capturou Cérbero, o cão do reino de Hades. v. 13 ...

Hércules: v. HÉRACLES

HERMAFRODITO (DD 15; 23) - Filho de Hermes e de Afrodite

HERMES (DD 3; 4; 9; 10; 14; 15; 17; 20 22; 24; 26|DDM 7; $11 \mid D M 4$; 5; 10; 18; 22; 23; 27; 30) — Filho de Zeus e da ninfa Maia. Menino prodígio, cometeu, ainda bebé, façanhas admiráveis: rouba o gado de Apolo e inventa a lira de sete cordas. Entre outras funçóes, é mensageiro dos deuses e condutor das almas para o reino de Hades.

HIMENEU (DD 20) — Filho de Afrodite e de Dioniso, é a divindade que preside à união dos amantes, após casamento legal, ao contrário de Eros.

HÍMERO (DD 20) — Irmão de Eros, ambos filhos de Afrodite. Personificaçấo do desejo apaixonado.

HIPNO (Sono) (DD 10) - Filho da Noite, irmão gémeo da Morte (10.2).

ICÁRIO (DD 18; 21) — Pai de Penélope de Esparta, foi morto pelos seus companheiros embriagados.

ÍNACO - v. IO.

IO (DD 3) — Filha de Ínaco, um das mais célebres amores de Zeus e, por isso, odiada por Hera, que a transformou em vitela e pôs a guardá-la o monstro Argos, que tinha cem olhos, metade dos quais estava sempre vigilante. Hermes, porém, 
por ordem de Zeus, conseguiu adormecê-lo ao som da flauta e cortou-lhe a cabeça.

IXÍON ( $D D$ G — Rei dos Lápitas, povo selvagem da Tessália. Admitido no banquete dos deuses, tentou seduzir Hera, esposa de Zeus, pelo que este o condenou a ser amarrado a uma roda que girava continuamente.

JACINTO (DD 2; 14; $15 \mid D M$ 18) Formoso jovem amado por Apolo. Numa sessáo de treino de lançamento do disco, o projéctil lançado por Apolo foi desviado por Zéfiro (personificação de um vento), que também amava o jovem, atingindo-o mortalmente. Apolo e Afrodite deram sepultura ao jovem, de cujo sangue fizeram uma flor com o seu nome, e em cujas pétalas os antigos viam as letras AIAI (interj. $\alpha i$ $\alpha i)$.

JÁPETO (DD 2; 7$)$ — Divindade antiquíssima, um dos Titâs, pai de Prometeu e de Epimeteu. Símbolo da velhice: «mais velho que Jápeto».

JASÃO (DD 16) - Chefe dos argonautas em busca do velo de oiro.

Juno: v. HERA

Júpiter: v. ZEUS

LATONA (designação latina usual, = gr. Leto) (AFP 38) — Mãe de Apolo e de Ártemis.

LEDA (DD 20; 24; 26|DM 18) - Esposa de Tíndaro, rei de Esparta. Foi amada por Zeus, que lhe apareceu sob a forma de cisne, pelo que teve quatro filhos, nascidos de dois ovos: Helena e Pólux, e Castor e Clitemnestra.
LETO: v. LATONA.

\section{Lua: v. SELENE}

MAIA (DD 7; 22; 24) - Ninfa, a mais velha das Plêiades, foi amada de Zeus, de cuja união nasceu Hermes.

MÁRSIAS (DD $16 \mid B I$ 5) — Um sátiro, grande tocador de flauta (algumas lendas consideram-no seu inventor), desafia Apolo para competir consigo com a cítara. Os juízes, numa votação quase unânime, deram a vitória a Apolo, que esfolou vivo o seu adversário.

Marte: v. ARES

MÉNADES (DD 2; 22) — Ninfas agrestes, às quais Hermes confiou Dioniso, fazem parte do séquito barulhento e orgiástico deste deus.

MENELAU (DD 20 | DDM 4 |DM 19) - Esposo de Helena, a qual foi raptada por Páris, facto que deu origem à guerra de Tróia.

\section{Mercúrio: v. HERMES}

\section{Minerva: v. ATENA}

MOMO (DD 20) - Deus da troça, punha defeito em tudo.

MUSAS (DD 16; $19|D D M 7| B I$ 3; 8) — Filhas de Zeus e de Mnemósine ("Memória»). Habitam o Hélicon e o Parnaso, onde, dirigidas por Apolo, executavam a música e o canto. Sấo nove irmãs, todas dedicadas às coisas do espírito, mais tarde repartidas por diversas especialidades: história (Clio), poesia lírica (Euterpe), poesia elegíaca (Érato), poesia épica (Calíope), tragédia (Melpómene), comédia (Talia), dança e canto (Terpsícora), 
hinos e, mais tarde, mimo (Polímnia) e astronomia (Urânia).

\section{Neptuno: v. POSÍDON}

NEREIDA(S) (DD $1 \mid$ DDM 3; 6; 7; 10; 14) - As cinquenta filhas do deus marinho Nereu. As mais famosas são Aretusa, Galateia e Tétis, mãe de Aquiles.

NEREU (V. Dóride, Galateia, Nereidas) - Filho de Ponto e de Geia, marido de Dóride e pai das Nereides.

NINFAS (DD 9) - Divindades concebidas em forma de belas jovens «noivas». Personificaçáo das fontes, nascentes, rios, florestas e montanhas...

NÍOBE (SVL $14 \mid$ DD 16) — Filha de Tântalo, teve sete filhas e sete filhos, de quem estava orgulhosa, demasiado orgulhosa para o "gosto" dos deuses, muito especialmente de Apolo e Ártemis, que mataram, primeiro, os sete rapazes e, a seguir, as sete raparigas, que haviam acorrido aos gritos dos irmáos. De tanto chorar a perda dos filhos, Níobe desfez-se em lágrimas.

ÔNFALE (DD 13) — Rainha da Lídia, em cuja corte Héracles cumpriu um período de escravatura, durante o qual herói limpou o país de bandidos que o assolavam.

PĀ $(D D 4 ; 22)$ — Divindade originária da Arcádia. Filho de Hermes e de uma de várias... mães (Cilena, Dríope, ou Penélope de Esparta: 22, 1-2). A iconografia apresenta-o com cornos e pés de bode.

PÁRIS (ou Alexandre) (DD $20 \mid D M$ 19)

- Filho do rei de Tróia, Príamo, foi o juiz, indicado por Zeus, do concurso de beleza que envolveu Hera, Atena e Afrodite, à qual atribuiu a vitória, em troca do que a deusa do amor lhe proporcionou o rapto de Helena, esposa de Menelau, facto que originou a guerra de Tróia.

PÉAN — (v. APOLO...)

PELÓPIDAS (DD 20) — Descendentes de Pélops (Menelau, Agamémnon...).

PENÉLOPE (DC $12 \mid$ DD 22) — Filha de Icário, esposa de Ulisses. Segundo Luciano (D. D., 22,1-2), da sua união com Hermes nasceu Pá.

PERSÉFONE (lat. Prosérpina) (DD 11 $\mid D M$ 23) - Esposa de Hades (Plutáo), rainha do Inferno.

PIRÍTOO ( $D D$ G) - Um dos centauros, rei dos Lápitas, tentou raptar Perséfone do reino de Hades, onde acabou por ficar preso. Foi libertado pelo seu amigo Héracles.

PÍTIS (DD 22) — ninfa amada por Pã.

PLUTÃO: v. HADES

PÓLUX: v. CASTOR E PÓLUX

POSÍDON (DC 14:juramento; DD 7; 9; 19; $21 ; 26 \mid D D M ~ 1 ; 2 ; 3 ; 5 ; 6 ; 7$; 8; 9; 13; 15) - Deus dos mares, irmão de Zeus e de Hades (Plutăo), pai do ciclope Polifemo. É representado com o tridente e cercado de golfinhos.

POTO (DD 20) — (Пó日os)

PRÍAMO (DD $20 \mid D D M 7)$ - Rei de Tróia no tempo da célebre guerra. Pai de Páris e de Heitor.

PRIAPO (DD 23) - Deus da fecundidade, originário de Lâmpsaco, nas 
margens do Mar Negro. Ao princípio, representado por um falo, foi-lhe posteriormente acrescentado um corpo. É dado como filho de Afrodite (ou de uma ninfa). Em Roma, era o guarda das hortas, exibindo dois temíveis apêndices: o falo e a foice.

PROMETEU $(D D 1)$ - «Aquele que pensa antes», "o previdente», irmâo de Epimeteu «aquele que pensa depois». Um dos Titâs, lutou ao lado de Zeus na guerra e conspiração dos gigantes. Criador do homem, por ele modelado em barro, torna-se o patrono dos oleiros. Benfeitor da Humanidade, roubou o fogo aos deuses para o entregar aos homens, ensinou-lhes o alfabeto e a aritmética, a metalurgia, etc., pelo que foi duramente castigado por Zeus, que ordenou que o amarrassem num rochedo do Cáucaso...

Prosérpina: v. PERSÉFONE

PROTEU (DDM 4) — Filho de Posídon e de Tétis. Transformava-se em diversos monstros e até em água e fogo | Filósofo cínico (BI 14)

REIA (DD 10; 12; 19) — Velha deusa do grupo dos Titâs, por vezes confundida com Gê (Terra»), e também, mais tarde, com Cíbele. Esposa de Cronos (10,2). Apaixona-se por Átis.

SELENE (Lua) (DD 10; 11; $12 \mid$ AFP 35; 39) — Irmã de Hélio, o Sol, também por vezes identificada com Ártemis. Apaixonada pelo jovem Endímion, que gostava de surpreender enquanto dormia.

SÉMELE (DD 9; 24) — Filha de Cadmo e de Harmonia, mãe de Dioniso, gerado da sua união com Zeus, que a assediou sob a forma de chuva. Tendo-lhe ela, um dia, pedido que o deixasse ver em toda a sua grandeza, Zeus acedeu, mas Sémele náo resistiu e morreu fulminada pelo raio, com o feto dentro de si, que Zeus introduziu na própria coxa, até perfazer o tempo de gestação.

Sol: v. HÉLIO

TÁRTARO (DD 19) - A regiāo mais profunda do Inferno, onde eram lançados os maiores criminosos, como Tântalo, Sísifo e outros.

TESEU (DD 20) — Filho de Egeu, rei de Atenas (ou de Posídon), é o herói de Atenas por excelência, cometendo feitos que o tornam quase igual a Héracles. A sua maior façanha teve lugar em Creta, onde venceu o Minotauro.

TÉTIS (DC $13 \mid D D$ 1; $21 \mid D D N 7 ; 10$; 12 | DM 29) - A mais famosa das nereidas (filhas de Nereu), ajudou Zeus a jugular uma conspiração tramada por Hera, Posídon e Atena, chamando em socorro de Zeus Briareu, gigante de cem braços. $(21,2)$. Desposou o mortal Peleu, de cuja uniāo nasceu o herói Aquiles.

TITÃS (DD 25) — Divindades primitivas, filhos de Úrano (o Céu) e de Gê (a Terra), eram (segundo Hesíodo) doze, seis de cada sexo: Oceano, Ceos (Koios), Jápeto, Crono, Crio, Hiperíon; Teia, Reia, Témis, Febe, Mnemósine e Tétis (Téthys: náo confundir com a nereida Tétis).

TRIPTÓLEMO (SVL 15) - Inventor e divulgador da agricultura. 
Vénus: v. AFRODITE

Vulcano: v. HEFESTO

ZÉFIRO (DD $14 \mid D D M 11 ; 15)$ - Personificação do vento oeste.

ZEUS (SVL 8|DD 1-6; 7; 8; 9; 10; 12; 13; 16; 18; 19-22; 24; $25 \mid D D M 1 ; 7$; 9; $11 ; 12 ; 15 \mid D M 14 ; 16 ; 23 ; 28$ AFP 18; 40; 48) — filho de Crono e de Reia. Como o pai tivesse o costume de devorar os filhos, a máe, logo após o parto, na ilha de Creta, escondeu-o no seio da grande mãe Terra, onde foi criado pelas ninfas das nascentes e alimentado com o mel do monte Ida e o leite da cabra Amalteia. Esta, ao brincar com Zeus, quebrou um corno, o qual se tornou o chamado "corno da abundância». Ao chegar à idade adulta, Zeus conspirou contra o pai, acabando por destroná-lo e tornando-se, assim, o deus supremo. No entanto, embora guardando para si o domínio dos céus, cedeu aos irmãos, Posídon e Hades (Plutão), respectivamente, os mares e o reino dos mortos. Teve de fazer frente a diversas conspiraçôes, mas de todas saiu vencedor. Casou com Hera, a quem era permanentemente infiel, gerando assim uma numerosa prole de homens e semideuses, o mais famoso dos quais é Héracles, nascido da sua uniāo com Alcmena, esposa de Anfitriāo. Este e outros aspectos da moral dos deuses e do rei dos deuses e dos homens náo podia deixar de merecer violentas críticas de um número cada vez maior de intelectuais. [V. Diálogos dos. Deuses: 1-2, 8 , etc.] 
(Página deixada propositadamente em branco) 


\section{Volumes publicados na ColecÇão Autores Gregos e Latinos - Série Textos Gregos}

1. Delfim F. Leão e Maria do Céu Fialho: Plutarco. Vidas Paralelas - Teseu e Rómulo. Tradução do grego, introdução e notas (Coimbra, CECH, 2008).

2. Delfim F. Leão: Plutarco. Obras Morais - O banquete dos Sete Sábios. Tradução do grego, introduçáo e notas (Coimbra, $\mathrm{CECH}, 2008)$.

3. Ana Elias Pinheiro: Xenofonte. Banquete, Apologia de Sócrates. Tradução do grego, introdução e notas (Coimbra, CECH, 2008).

4. Carlos de Jesus, José Luís Brandão, Martinho Soares, Rodolfo Lopes: Plutarco. Obras Morais - No Banquete I - Livros $I-I V$. Tradução do grego, introdução e notas. Coordenação de José Ribeiro Ferreira (Coimbra, CECH, 2008).

5. Ália Rodrigues, Ana Elias Pinheiro, Ândrea Seiça, Carlos de Jesus, José Ribeiro Ferreira: Plutarco. Obras Morais - No Banquete II - Livros V-IX. Tradução do grego, introdução e notas. Coordenação de José Ribeiro Ferreira (Coimbra, $\mathrm{CECH}, 2008)$.

6. Joaquim Pinheiro: Plutarco. Obras Morais - Da Educação das Crianças. Tradução do grego, introdução e notas (Coimbra, $\mathrm{CECH}, 2008)$.

7. Ana Elias Pinheiro: Xenofonte. Memoráveis. Tradução do grego, introdução e notas (Coimbra, CECH, 2009).

8. Carlos de Jesus: Plutarco. Obras Morais - Diálogo sobre o Amor, Relatos de Amor. Tradução do grego, introdução e notas (Coimbra, CECH, 2009).

9. Ana Maria Guedes Ferreira e Ália Rosa Conceição Rodrigues: Plutarco. Vidas Paralelas - Péricles e Fábio Máximo. Tradução do grego, introdução e notas (Coimbra, CECH, 2010).

10. Paula Barata Dias: Plutarco. Obras Morais - Como Distinguir um Adulador de um Amigo, Como Retirar Benefício dos Inimigos, Acerca do Número Excessivo de Amigos. Tradução do grego, introduçáo e notas (Coimbra, CECH, 2010). 
11. Bernardo Mota: Plutarco. Obras Morais - Sobre a Face Visivel no Orbe da Lua. Tradução do grego, introdução e notas (Coimbra, CECH, 2010).

12. J. A. Segurado e Campos: Licurgo. Oração Contra Leócrates. Tradução do grego, introdução e notas (Coimbra, CECH /CEC, 2010).

13. Carmen Soares e Roosevelt Rocha: Plutarco. Obras Morais - Sobre o Afecto aos Filhos, Sobre a Música. Tradução do grego, introdução e notas (Coimbra, CECH, 2010).

14. José Luís Lopes Brandão: Plutarco. Vidas de Galba e Otão. Tradução do grego, introdução e notas (Coimbra, CECH, 2010).

15. Marta Várzeas: Plutarco. Vidas de Demóstenes e Cícero. Tradução do grego, introdução e notas (Coimbra, CECH, 2010).

16. Maria do Céu Fialho e Nuno Simóes Rodrigues: Plutarco. Vidas de Alcibiades e Coriolano. Tradução do grego, introdução e notas (Coimbra, CECH, 2010).

17. Glória Onelley e Ana Lúcia Curado: Apolodoro. Contra Neera. [Demóstenes] 59. Tradução do grego, introdução e notas (Coimbra, CECH, 2011).

18. Rodolfo Lopes: Platão. Timeu-Critías. Tradução do grego, introduçáo e notas (Coimbra, CECH, 2011).

19. Pedro Ribeiro Martins: Pseudo-Xenofonte. A Constituição dos Atenienses. Tradução do grego, introdução, notas e índices (Coimbra, CECH, 2011).

20. Delfim F. Leão e José Luís L. Brandão: Plutarco.Vidas de Sólon e Publícola. Tradução do grego, introdução, notas e índices (Coimbra, CECH, 2012).

21. Custódio Magueijo: Luciano de Samósata I. Tradução do grego, introdução e notas (Coimbra, CECH/IUC, 2012). 
(Página deixada propositadamente em branco) 


\section{OBRA PUBLICADA}

COM A COORDENAÇÁO

CIENTÍFICA

0
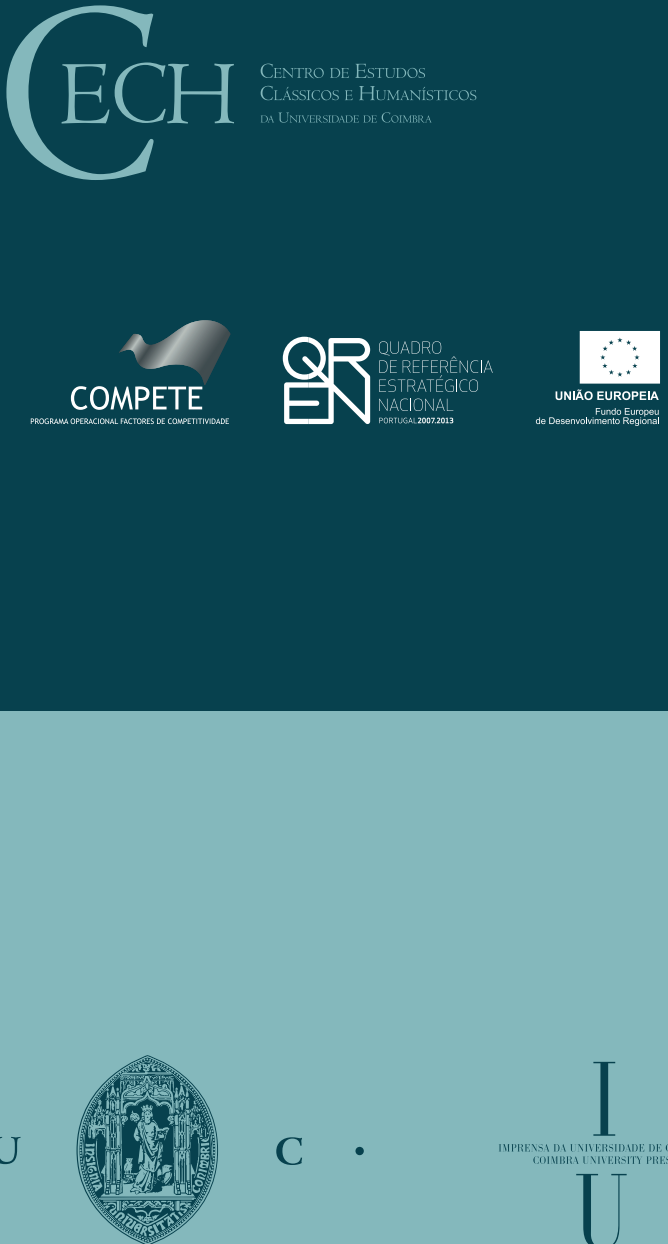

C. 